\title{
39. CENOZOIC PLANKTONIC FORAMINIFERA AND BIOSTRATIGRAPHY, ARABIAN SEA DEEP SEA DRILLING PROJECT, LEG 23A
}

\author{
Robert L. Fleisher, Department of Geological Sciences, University of Southern California, Los Angeles, California
}

\section{INTRODUCTION}

Recent reconstructions of the Mesozoic and Cenozoic spreading history of the Indian Ocean (McKenzie and Sclater, 1971) have provided a hypothetical framework within which geostructural and faunal events may be examined. Drilling during DSDP Leg 23A (March-April, 1972) was conducted with the aim, not only of determining the sedimentary and biostratigraphic history of selected regions in the Arabian Sea, but of comparing the ages determined for igneous basement with the predictions of McKenzie and Sclater's model. The degree of corroboration and the implications of observed sea-floor ages for the geotectonic interpretation of Indian Ocean history are discussed elsewhere in this volume.

Sediments were recovered from seven holes at six sites (219 through 224) in the Arabian Sea. Location and recovery data are presented below (Figure 1, Table 1). In terms of their objectives, and to a lesser extent their geographic positions, the sites may be divided into three groups.

Sites 219 and 220 are associated with the ChagosLaccadive Ridge, a north-south-trending structure extending southward from the eastern margin of the Arabian Sea. The former is located near the crest of the ridge, in a relatively deep gap between shoal areas represented geographically by the Laccadive and Maldive Island groups. Prior to the drilling of Site 219, coral rock and related debris represented the only sedimentary rock recovered from this ridge. As a result, its Tertiary sedimentary history was unknown, as well as the nature of the underlying basement. Site 220 is situated slightly to the southwest, in deeper water along the western flank of the ChagosLaccadive Ridge within a quiet magnetic zone (McKenzie and Sclater, 1971). It was anticipated that igneous basement at this location would be no older than 38 m.y. (Late Eocene). The primary objectives of drilling at Site 220 included the sampling of this basement and the age determination of a shallow unconformity observed in seismic records. The extensive sedimentary sequences at these sites contained the only abundant and well-preserved planktonic foraminiferal faunas recovered during Leg 23A.

Sites 221 and 222, although a considerable distance apart, lie within similar modern sedimentary environments. Both are situated within the main (Arabian) basin of the central Arabian Sea, the former near the western flank of the Chagos-Laccadive Ridge and the latter slightly east of the Owens Fracture Zone. These sites are near the distal margin of the Indus Cone, where it was expected that upper Tertiary and Quaternary detritus supplied by the Indus River would be relatively thin. At the former site, a distinct reflector horizon was presumed to represent the Eocene

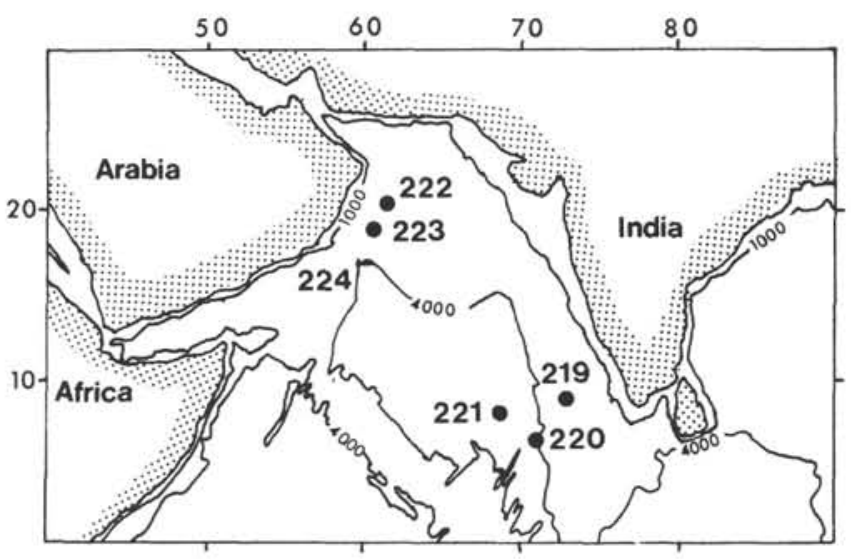

Figure 1. Location map for DSDP Leg 23A sites. Contours in meters.

chert recovered at Site 220 . No such reflector was observed on the seismic records at Site 222, where the primary objective entailed the determination of the sedimentary history of the Indus Cone and the relation of that history to periods of uplift in the Himalayas.

Sites 223 and 224, drilled along the western flank of the Owens Fracture Zone, were primarily concerned with the interpretation of the history of that structure. As the location of these sites is shielded from Indus Cone deposits by this ridge, it was anticipated that upper Tertiary sediment thicknesses of the magnitude observed at Site 222 would not be encountered. Determination of the age of igneous basement was thus a principal purpose of drilling operations, particularly in view of the possibility that, as recognized on the Ninetyeast Ridge (von der Borch et al., 1972), the age of the Owens Fracture Zone might vary along its length. Furthermore, the age determined for the lowest recovered sediment above basement at Site 223 is considerably younger than that predicted by the McKenzieSclater model, and the final site represents an attempt to determine whether that age is representative for the fracture zone in this region.

\section{PLANKTONIC FORAMINIFERAL ZONATION}

\section{Introduction}

At the present stage in the development of planktonic foraminiferal biostratigraphy, there is little shortage of zonation systems available for the subdivision of the Cenozoic. The most widely employed, however, are those developed by Bolli (1957a, 1957b, 1957c, 1966), including closely related zonal schemes (e.g., Postuma, 1971), and by Banner and Blow (1965) and Blow (1969). It was felt, in 
TABLE 1

Location, Water Depth, and Recovery Data for Leg 23A Sites

\begin{tabular}{|c|c|c|c|c|c|c|}
\hline & 219 & 220 & 221 & 222 & 223 & 224 \\
\hline Latitude (N) & $09^{\circ} 01.75^{\prime}$ & $06^{\circ} 30.97^{\prime}$ & $07^{\circ} 58.18^{\prime}$ & $20^{\circ} 05.49^{\prime}$ & $18^{\circ} 44.98^{\prime}$ & $16^{\circ} 32.51^{\prime}$ \\
\hline Longitude (E) & $72^{\circ} 52.67^{\prime}$ & $70^{\circ} 59.02^{\prime}$ & $68^{\circ} 24.37^{\prime}$ & $61^{\circ} 30.56^{\prime}$ & $60^{\circ} 07.78^{\prime}$ & $59^{\circ} 42.10^{\prime}$ \\
\hline Depth (m) & 1764 & 4043 & 4650 & 3546 & 3633 & 2500 \\
\hline No. of Cores & 31 & 21 & 19 & 36 & $41^{\mathrm{a}}$ & 11 \\
\hline Penetration $\mathrm{b}$ & 411 & 350 & 270 & 1300 & 740 & 792 \\
\hline $\mathrm{Age}^{\mathrm{c}}$ & $\begin{array}{l}\text { Late } \\
\text { Paleocene }\end{array}$ & $\begin{array}{l}\text { Early } \\
\text { Eocene }\end{array}$ & $\begin{array}{l}\text { Middle } \\
\text { Eocene }\end{array}$ & $\begin{array}{l}\text { Late } \\
\text { Miocene }\end{array}$ & $\begin{array}{l}\text { Late } \\
\text { Paleocene } \\
\text { (?) }\end{array}$ & Eocene \\
\hline
\end{tabular}

\footnotetext{
${ }^{\text {a }}$ Plus one additional sidewall core above igneous basement.

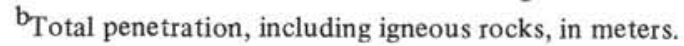

${ }^{\mathrm{c}}$ Age of lowest dated fossil assemblage.
}

the preparation of this report, that the purposes of a preliminary study such as this would be best served by the use of the Blow (1969) zonation system for the late Middle Eocene to Holocene. The zones used here for the remainder of the Paleogene are largely those proposed by Bolli (1966), but the modifications and the application of "letternumber" nomenclature advanced by Berggren (1971a, 1972) have been adopted. The "abbreviated letter and number method of naming the zones" has been found objectionable (Jenkins and Orr, 1972) as a violation of proper stratigraphic terminology, but all of the zones involved have been properly defined (Blow, 1969), and the zone terminology should best be considered as a mnemonic device.

There are, nonetheless, serious problems in the application of Blow's zonation scheme to Indian Ocean populations. It is unreasonable to expect any set of zones to be uniformly applicable to planktonic foraminiferal assemblages because these species are not themselves uniformly distributed (Parker, 1965; Boltovskoy, 1971). One of the important boundaries in Blow's system is the initial appearance of Globorotalia (T.) truncatulinoides at the base of the Pleistocene from its ancestor, $G$. (T.) tosaensis. The ancestral species probably had much the same environmental preferences as the descendent, but the latter is much less common in the tropics than in subtropical and temperate regions (Bé and Tolderlund, 1971). As a result, the Pliocene-Pleistocene boundary could be determined only approximately in the Arabian Sea (and not at all in the Red Sea), and the base of N.21 (G. [T.] tosaensis consecutive-range zone) could not be conclusively recognized on the basis of its defining characteristic (initial appearance of $G$. tosaensis). Kleinpell (1972), in a commentary critical of "mundial" planktonic correlations, suggested that many planktonic zones are "as often as not ... just a teilzone or biozone based on a single taxon rather than a Zone based on the multiple stratigraphic ranges of taxa that enchance (sic) its degree of probability commensurately" (p. 110). Blow (1970) has effectively responded to this line of argument, but it should be noted that the problem of irregular or climate-controlled species distribution becomes more critical when dealing with fossil assemblages where no living species are present.
It seems certain that Blow's zonation does not represent the ultimate solution to the problems of planktonic foraminiferal biostratigraphy. Brönnimann and Resig (1971) have proposed a number of modifications in Neogene zones, most of which are supported by data observed in Arabian Sea populations. Berggren (1973) and Cita (1973) have proposed new zonations for the Pliocene interval for which the Blow sequence is particularly susceptible to modification. These proposed Pliocene systems, however, are not entirely applicable to Arabian Sea sequences and are not employed here, but they are probably suitable for Atlantic and Mediterranean assemblages. It seems likely as well (Berggren, 1971a) that finer subdivisions of the Cenozoic will become increasingly possible as more is learned about planktonic species evolution, at least within local regions. The "letter-number" system is particularly inflexible with respect to further subdivision.

Finally, the utility of the Blow zones is somewhat reduced by the solution of critical species at oceanic depths. Solution susceptibilities are fairly well known for modern forms (Berger, 1970), and it may prove possible to use this information to provide data on the test solution of extinct species and assemblages (Berger and von Rad, 1972). Jenkins and Orr $(1971,1972)$ have proposed zones based upon solution-resistant species, but these have not been used here. For the most part, solution levels in Leg 23A sediments have resulted in a feast-or-famine condition. Either solution is sufficiently low that the Blow zones can be satisfactorily employed, or it has been so intense that only a tentative age determination, at best, can be made.

Because the planktonic faunas are entirely representative of tropical conditions throughout the Cenozoic, the use of the Blow (for the late Paleogene and Neogene) and Bolli-Berggren (early Paleogene) zones provides a satisfactory framework for the examination of Leg 23A planktonic foraminiferal assemblages. Some necessary modifications will be presented in the following section.

Several other DSDP cruises (Legs 22 through 27) have collected cores from tropical and subtropical regions of the Indian Ocean, and when all of the resultant data become available, it may prove possible to construct a zonation specifically suited to Indian Ocean assemblages. Similar 
regional zonal systems have resulted from several prior cruises (e.g., Bolli, 1970; Krasheninnikov, 1971). The temptation to propose a local zonation based on Leg 23A sequences, however, has been resisted. Well-preserved faunas were recovered over extensive stratigraphic intervals only at Sites 219 and 220 , and the suitable sequences overlap only in a short portion of the early Middle Eocene. It would be inappropriate, therefore, to propose a zonation based upon what is effectively a single stratigraphic section, particularly as that section includes several hiatuses representing considerable portions of time.

Special caution was directed during the study of the Arabian Sea faunas to the recognition of contamination introduced during drilling operations. Natural "contamination" due to reworking is evident in a number of cores and was usually recognized. Downhole contamination resulting from drilling and coring operations was generally obvious as well-modern species mixed with Middle Eocene assemblages near the base of Hole 219, for instance-but when the age differential of the mixed elements is small, recognition is considerably more difficult. It cannot be demonstrated that all such situations have been noted, and some artifically extended species ranges may appear in the range charts included in this report. The author is convinced, however, that no significant instances of contamination were overlooked. Based upon experience with the Leg 23 cores, it appears that two regions of each core, the core catcher and the highest section, are particularly susceptible to contamination of this sort. The mechanism for emplacement of displaced specimens in the former is not clear; the latter case presumably results from slumping of higher material down the hole between cores. In most cases, contaminating material was not observed within the interior of the cores (i.e., between Sections 1 and CC). It should also be noted that the highest section is particularly likely to contain slumped sediment in the first core recovered from below a drilled interval, which may provide an explanation for such minor unconformities as the one observed in Site 219, Core 13, Section 1. There seems to be no certain way to determine whether the sediment above an apparent unconformity of this sort is actually in place.

\section{Discussion of Selected Cenozoic Zone Boundaries}

\section{Quaternary}

Blow (1969) informally proposed a Late Quaternary Globigerina calida calida/Sphaeroidinella dehiscens excavata Assemblage Zone (N.23), to which these species, as well as Globigerinella adamsi and Hastigerinella rhumbleri $(=H$. digitata) are putatively restricted. Brönnimann and Resig (1971) have discussed the problems involved in recognizing this stratigraphic unit. At Site 219, as in the southwestern Pacific, S. dehiscens excavata was not observed and $G$. calida calida initially appears just below the base of the Pleistocene. Fragmentary remains of $G$. adamsi were noted in the highest recovered sample, suggesting that its range is limited to the latest Pleistocene and Holocene. The author therefore concurs with Brönnimann and Resig that the N.22/N.23 boundary should be recognized just below the earliest appearance of this distinctive species.
The Pliocene-Pleistocene boundary (N.21/N.22) is defined by the evolution of Globorotalia (T.) truncatulinoides from its ancestor, G. (T.) tosaensis (Banner and Blow, 1965). This event has subsequently been found (Glass et al., 1967) to correlate closely with the Gilsa paleomagnetic event, approximately 1.8 m.y.B.P. Although $G$. (T.) truncatulinoides is relatively rare in tropical waters, the boundary has presented no serious problems in most deep-sea tropical sediments. Recently, however, Theyer (1973) has presented evidence to indicate that this species is present in subantarctic regions in deposits as old as Early Pliocene. As of the time of this writing, Theyer's conclusions have not been verified elsewhere and are the subject of considerable dispute (J. P. Kennett, personal communication). In accordance with the general practice, the boundary has been recognized as defined by Blow (1969), particularly as this horizon, as so drawn in Arabian Sea sediments, is in good accord with the nannofossil evidence as well as with other foraminiferal events known to occur near the boundary (e.g., extinction of "Globigerina" rubescens decoraperta, initial appearance of "G." tenella).

\section{Pliocene}

Considerable difficulty was encountered in applying Blow's zones to the Pliocene (well-preserved assemblages of Pliocene and Late Miocene age were encountered only at Site 219), and it appears likely that a new subdivision of this interval will be required. The N.20/N.21 boundary is based upon the initial appearance of Globorotalia (T.) tosaensis, a species which is extremely rare in the Arabian Sea. The boundary as drawn beneath the lowest occurrence of this form very nearly corresponds to the extinction levels of Globorotalia (G.) multicamerata and Globoquadrina altispira, and this horizon appears to closely approximate (Berggren, 1972, 1973) the horizon intended by Blow.

Brönnimann and Resig (1971) suggested that Zone N.20 requires redefinition because the range they observed for Turborotalia (T.) pseudopima, whose initial appearance was reported (Blow, 1969) to mark the N.19/N.20 boundary, extended continuously as low as the top of N.18, with isolated occurrences as low as the base of that zone. These authors instead placed the N.19/N.20 boundary at a horizon marked, in, their cores, by the extinctions of Globorotalia (H.) margaritae and Sphaeroidinella dehiscens immatura and the initial appearances of Globorotalia (T.) crassaformis oceanica and $G$. (G.) cultrata exilis (cf. the discussion of this species in the Systematics section below under G. [G.] cultrata). T. (T.) pseudopima is rare in Leg $23 \mathrm{~A}$ samples, and although its initial appearance lies within the combined N.19-N.20 interval at Site 219, it does not seem justified to draw a boundary at this horizon.

Berggren (1973), like Brönnimann and Resig, recognized the extinction of $G$. (H.) margaritae as a datum contemporaneous with the N.19/N.20 boundary, and Blow (1969) recognized another event, the initial appearance of "Globigerina" rubescens s.s., at this level. The base of N.19, on the other hand, is marked by the following faunal events: the initial occurrence of Sphaeroidinella dehiscens immatura and (just below the boundary) the extinctions of 


\section{Globorotalia (G.) merotumida and Globorotaloides variabilis.}

Of the species mentioned above, two (Globorotalia [T.] crassaformis oceanica and G. [G.] cultrata exilis) do not occur at Site 219. The remaining events-the extinctions of Globorotalia (H.) margaritae, G. (G.) merotumida, and Globorotaloides variabilis and the appearances of "Globigerina" rubescens s.s. and $S$. dehiscens immatura-all occur within 1.5 meters in Core 6 . It must be concluded that either Zone N.19 is very short or absent or that Zones N.19 and N.20 cannot be distinguished here as defined. The author has chosen, like Brönnimann and Resig, the latter interpretation.

Recent interest in the stratotype Messinian (Late Miocene) section, in part generated by DSDP drilling in the Mediterranean, has resulted in close examination of planktonic foraminiferal events in the Late Miocene and Early Pliocene. Although some workers (Parker, 1967; Bandy, $1971,1972 a$ ) have placed the Miocene-Pliocene boundary at the initial occurrence of Sphaeroidinella dehiscens s.l., it now appears (Berggren, 1973) that this boundary should be placed at the base of N.18, defined by the initial appearance of Globorotalia (G.) tumida s.s. To use the Sphaeroidinella "datum" would imply the local extinction of G. (H.) margaritae at the top of the Miocene-unlikely in view of its range elsewhere (Beckmann, 1972; Ciaranfi and Cita, 1973)-and the basal Pliocene evolution of " $G$." rubescens s.s. Berggren (personal communication) has suggested that the Sphaeroidinella datum is time transgressive, a conclusion supported by this occurrence. The base of the Pliocene, therefore, is placed at the N.17/N.18 boundary.

\section{Early Miocene}

Brönnimann and Resig (1971) noted that the range of Globigerinoides sicanus is greater than that ascribed to it by Blow (1969). The complete absence of Catapsydrax stainforthi at the Arabian Sea sites precludes direct verification of the observed overlap of these two species, and it seems appropriate to accept the conclusion that Zones N.7 and N.8 cannot be distinguished. No planktonic faunas of N.6 age were collected below the upper lower Miocene sediments, however, and nothing in the foraminiferal populations excludes the possibility that all faunas assigned to the N.7-N.8 interval are entirely of N.8 age (i.e., younger than the extinction of $C$. stainforthi).

\section{Oligocene}

The Oligocene does not appear to have been a time of rapid evolutionary advance among planktonic foraminifera (Berggren, 1969b), and the zonation of this interval is difficult under the best of conditions. The recognition of Oligocene zones at Arabian Sea sites is further complicated by the nearly complete absence of all species of Globigerina s.s. (spinose-walled globigeriniform species), as well as Globoquadrina sellii. Among the former, Globigerina angulisuturalis is particularly critical in that its evolutionary appearance from $G$. anguliofficinalis delimits the base of P.21. The absence of this species from DSDP Arabian Sea cores is somewhat surprising in view of its presence, albeit rare, in the subsurface sediments of the nearby Cauvery
Basin in southeastern India (Raju, 1971). The P.20/P.21 boundary can be approximated by the extinction of Turborotalia (T.) ampliapertura, but this species is similarly absent in samples whose faunas can be referred equally well to either zone. These two zones, therefore, were not distinguished. P.22 could best be recognized, in the absence of $G$. angulisuturalis, by the co-occurrence of Turborotalia (T.) siakensis and Globoquadrina tripartita s.s. in the absence of T. (T.) opima opima and Globigerinoides spp., although recently available evidence (Sieglie, 1973; F. Steininger, personal communication) suggests that Globigerinoides quadrilobatus primordius may have evolved within the time interval represented by this zone.

The earliest occurrence of Globoquadrina sellii represents the P.18/P.19 boundary. A few samples at Site 223 (Core 31 ) could be tentatively referred to P.18 on the basis of the joint presence of Turborotalia (T.) pseudoampliapertura and Subbotina angiporoides (both of which disappear shortly above the boundary) because $G$. sellii was observed in superposed sediments. Its absence in Core 31 thus has probable stratigraphic significance. At Site 219, however, G. sellii was nowhere observed, and whether a P.18 or P.19 age should be assigned to the relevant samples (Cores 15 and 16) cannot be conclusively determined.

\section{Early and Middle Eocene}

The application of zones to the early Middle and Early Eocene is hampered to a great extent by inadequate knowledge of many of the species present in this interval. A comparison of species ranges presented by Bolli (1957a, 1957c), Luterbacher (1964), and Berggren (1968, 1971a) illustrates this point, although all relate their sequences to essentially the same zonal scale. Changes in the knowledge of the evolution of planktonic communities are hardly surprising, of course, and indeed are welcome as representative of the contributions made by additional research. They present no special problems when they can be related to a well-defined biostratigraphic framework. Unfortunately, in the Arabian Sea sequences the Bolli-Berggren zones are difficult to apply as defined to the foraminiferal faunas. Uncertainties in the ranges of the accessory species thus increase the problems involved in subdividing the stratigraphic section. The use of these species (i.e., other than those on which the zones are defined) is further complicated by the format used in the publication of the latest synthesis of the ranges of Paleogene taxa. The ranges are related to neither well-defined zones nor sedimentary sequences, and the limits (Berggren, 1971a, figs. 2-5) are drawn to a level of precision insufficient for detailed application to particular biostratigraphic problems.

The basal Middle Eocene Zone (P.10) is defined by the range of Hantkenina (H.) mexicana aragonensis. The base is marked as well by the earliest appearance of this genus. All species of Hantkenina are rare in Arabian Sea sediments, and $H$. (H.) mexicana aragonensis is represented by fragmentary remains in a few samples at two Sites (219, 220). The P.10/P.11 boundary as drawn at the highest horizon in which this species is present in thus an approximation. The rarity of Hantkenina implies that the boundary might be located slightly higher. Bolli (1972), however, has noted that the evolutionary appearance of 
Globigerinatheka mexicana mexicana occurs very near this level, and this event at the two sites occurs just above the boundary as recognized.

The problems involved here in defining the Early-Middle Eocene boundary (P.9/P.10) result from the definition of the "Globorotalia palmerae" Zone (P.9) by Bolli (1957c). Most subsequent workers have considered the nominate species to be benthic rather than planktonic in habit, and its distribution tends to support this conclusion. Certainly, the morphology and wall texture of " $G$." palmerae, as described by Cushman and Bermúdez (1937), have little in common with the characteristics of other Early Eocene globorotaliform species other than general test form. Berggren (1968) renamed this interval the Acarinina densa (=A . bullbrooki) Zone, "defined by the concurrent-range of Acarinina densa and Globorotalia aragonensis prior to the first evolutionary appearance of Hantkenina aragonensis" (p. 20). The A. densa Zone is thus roughly equivalent to the Globorotalia pentacamerata Zone of other authors (Krasheninnikov and Ponikarov, 1965; Fahmy et al., 1969) and to the Globorotalia palmerae, Globigerina turgida-Globigerina senni, and Globorotalia spinulosa zones in the Cauvery Basin (Raju, 1970).

The scarcity of $A$. bullbrooki and $H$. (H.) mexicana aragonensis precludes the recognition of the P.9/P.10 boundary in the manner described by Berggren. All of the species reported by Bolli (1957c) to arise at this boundary are either absent in Arabian Sea samples or known to range lower. However, Berggren (1971a) has suggested that this boundary, equivalent to his "Hantkenina Datum," is straddled by the extinctions of Acarinia soldadoensis (somewhat below) and $A$. pentacamerata (somewhat above). A similar range for the latter species has been recognized by Luterbacher (1972) and Krasheninnikov and Ponikarov (1965), although it was recorded at a somewhat higher level in the Cauvery Basin (Raju, 1970). The extinctions of these two species, as observed in the Arabian Sea (Site 220), occur in successive samples, and as an approximation the boundary has been drawn between them. If the highest appearance of $A$. pentacamerata is older here than elsewhere for unrecognized environmental reasons, it may be that the P.9/P.10 boundary is placed somewhat too low.

\section{PALEOECOLOGICAL CONSIDERATIONS}

\section{Planktonic Foraminifera}

The plate-motion predictions proposed by McKenzie and Sclater (1971) for the Indian Ocean during the Cenozoic imply that several of the sites, particularly 219,220 , and 221, have moved northward through a considerable latitudinal range since the Late Cretaceous. It was felt, during the preliminary stages of investigation, that the paleoclimatic information provided by planktonic foraminiferal populations could be used to test this hypothesis and to determine the extent of northward translation.

These sites, however, presently lie within the tropical climatic zone, and the spreading model suggests, if correct, that they have been similarly situated since at least the end of the Paleogene, and within tropical or subtropical regions since the end of the Mesozoic. Knowledge of the climatic distribution of planktonic foraminifera is too rudimentary to permit the distinction, from fossil populations, between faunas representative of these two ecological zones. Indeed, the relatively warm conditions thought to have prevailed throughout much of the early Tertiary prior to the Late Eocene (Steineck, 1971a; Frerichs, 1971) suggest a contemporaneous expansion of the tropics.

No indication was found in the planktonic assemblages of any deviation from typical warm-water associations. Oligocene faunas in the Arabian Sea are relatively nondiverse, but this characteristic appears to be generally true for planktonic populations of this age. The Oligocene, in any case, has been noted, with the Late Eocene, as a time of worldwide cooling (Frerichs, 1971). Bandy (1964a, 1967) has suggested the recognition of a "keeled line" marking the northern and southern limits of planktonic faunas containing keeled globorotaliform species. This boundary appears at present to separate tropical to warmtemperate from cool-water populations, an interpretation which appears to be generally true at least for Tertiary assemblages. The primary keeled genera, Globorotalia and Morozovella, are present in virtually all samples from Tertiary intervals when such species were living (i.e., except the Early Paleocene and late Late Eocene through late Early Miocene). In the recovered Early and Middle Eocene only three species of Morozovella are common (M. bandyi, $M$. coronata, and $M$. aragonensis), but this population is not strikingly restricted by comparison with most other faunas of the same age. The greatest diversity of morozovellids evolved during the Late Paleocene and early Early Eocene, time intervals for which well-developed representative faunas were not recovered during Leg 23A.

\section{Benthic Foraminifera}

No detailed study of paleobathymetry based on benthic foraminifera was undertaken for this report, and benthic species were not identified. For the most part, however, benthic populations are typical of oceanic depths, in terms of the criteria recognized by Bandy (1960). The two major exceptions, at Sites 219 and 222, and several minor ones largely involving transported neritic populations, are discussed below with respect to core descriptions.

\section{Test Dissolution}

The modifications in calcareous planktonic thanatocoenoses introduced by preburial test dissolution have received much attention, notably by Berger and von Rad (1972) and Jenkins and Orr $(1971,1972)$ among others. Most of the observed assemblages in recovered samples would be assigned FS values ("foram solution" code of Berger and von Rad) between 4 and 9 inclusive, although as these authors note, the application of the solution scale becomes more subjective with increasing age of the sample. No extended discussion of test dissolution patterns is presented here, although the effects of solution on the foraminiferal faunas is described in the following section. Some generalizations, however, are justified.

Solution effects in Late Neogene samples are variable between sites, and no overall conclusions can be drawn at present. At the shallower sites (notably 219), foraminiferal populations are relatively well preserved (FS 4 to 5, 
occasionally 6), but solution has been intense, resulting in complete or near-complete test destruction, in deeper water. The Late Eocene to middle Early Miocene appears to have been a period of increased solution, probably due to a rise in the lysocline and foraminiferal compensation depth. Decreased diversity and enhanced concentration of heavywalled species is characteristic of these populations and was noted as well at Leg 24 sites (E. Vincent, personal communication). The middle Tertiary increase in test solution may well have been of regional extent.

In contrast, evidence of dissolution is reduced in foraminiferal assemblages from silica-rich Early and Middle Eocene samples. The remarkable abundance of radiolarians in sediments of this age has been noted from most ocean basins (e.g., Riedel and Sanfilippo, 1970, 1971) and may have resulted from a modification of tropical surface water productivity. The evidence is not sufficient for a firm conclusion. In the Arabian Sea, well-preserved suites of planktonic foraminifera are commonly associated with the radiolarian faunas. At Sites 221 and 224, where postEocene faunas are essentially absent, highly but not completely dissolved faunas first appear in association with Middle Eocene radiolarians. The conclusion seems inescapable that the lysocline was located considerably deeper in the Early and Middle Eocene than at present, probably as a response to changes in patterns of deep-water circulation.

\section{SITE DESCRIPTIONS}

Preliminary discussions of the biostratigraphic sequence at each of the Arabian Sea sites are included in the appropriate site reports. Rather than simply repeating the information presented in the Shipboard Site Reports, the following section concentrates on the problems and details encountered in analyzing the Tertiary faunas.

\section{Site 219}

Late Neogene planktonic faunas are well-developed in Cores 1 through 12 , this is the only site where assemblages of this age are sufficiently well preserved for detailed biostratigraphic study. Fragmentary remains of Globigerinella adamsi were observed in Core 1, Section 1 and Core 2, Section 1. In view of the contamination patterns noted above, it is possible that both, and particularly the latter, were originally deposited in unrecovered sediments stratigraphically above Core 1 . The youngest sample examined $(1-1,110-112 \mathrm{~cm})$, however, is tentatively referred to Zone N.23 as previously defined.

Although fragmentation is moderate to high (FS 5 of Berger and von Rad, 1972), Pleistocene faunas are typical of tropical assemblages of this age. Globigerinoides ruber, the most soluble of common modern forms (Berger, 1970), is abundant throughout, and the most pronounced effect of calcite dissolution appears to be the fragmentation of larger tests and the removal of many of the smaller, more delicate forms, particularly juveniles. Globorotalia (T.) truncatulinoides is present but relatively rare as low as Core 4, Section 4.

There is inconclusive evidence to suggest the possibility of an unconformity near or spanning the PliocenePleistocene boundary, although this has not been indicated in the accompanying range charts nor discussed in Chapter
3 (this volume). Zone N.21 and the Discoaster brouweri Zone are somewhat shorter than might be anticipated, and the highest Pliocene sample contains rare glauconite grains. The Late Pliocene is also marked by substantially greater solution effects (FS 6) than the Pleistocene. The calculated sedimentation rate curve (Chapter 3) is consistent with either continuous or discontinuous deposition, however, and the nature of the boundary cannot be determined with any degree of certainty.

The difficulties involved in the zonal subdivision of the Pliocene at this site have already been discussed. The Late Miocene-Pliocene boundary is placed at the initial appearance of Globorotalia (G.) tumida tumida from its ancestor, G. (G.) tumida plesiotumida (Core 8, Section 5). This horizon corresponds to the extinction of Discoaster quinqueramus. The coincidence of these events is somewhat surprising in that the nannofossil species has been reported to disappear elsewhere within the Miocene (Bukry, 1971; Gartner, 1973) and may point to slight reworking of the nannoplankton. On the other hand, the transition from $G$. (G.) tumida plesiotumida to $G$. (G.) tumida tumida is gradational, and the taxonomic boundary becomes very difficult to draw in the earliest Pliocene. Some uncertainty, therefore, must remain under any circumstances in the recognition of the earliest forms of $G$. (G.) tumida tumida.

No consensus could be reached (cf. Chapter 3, Biostratigraphic Summary) on the age of Cores 9 through 12 . Although Akers (this volume) has assigned a late Middle Miocene age to this entire interval, as well as to Cores 7 and 8 , the foraminiferal evidence seems to the author clearly to indicate the presence of Late Miocene (N.17) faunas containing reworked early Middle Miocene species.

A number of species restricted to upper Miocene and younger sediments are present throughout. These include in particular Candeina nitida subspp., Globigerinoides conglobatus canimarensis, Globorotalia (G.) tumida plesiotumida, Turborotalia (T.) humerosa s.s., and T. (T.) acostaensis subspp. Pulleniatina spp. was observed as low as Sample 10, CC. The occurrence of $T$. (T.) acostaensis in these sediments is particularly significant. Because it is common in most samples below Core 9, its evolutionary appearance defines the N.15/N.16 boundary and approximates the Middle-Late Miocene boundary.

Reworked specimens are present sporadically below Core 2, but appear consistently below. Core 5 and commonly below Core 10 . Most species represented are of early Middle Miocene age, including, most commonly, Turborotalia (T.) siakensis and $T$. (T.) mayeri, as well as Globigerinoides subquadratus, Globorotalia (F.) fohsi s.l., $G$. (F.) peripheroronda, and $G$. (F.) peripheroacuta. Occasional specimens of Globigerinoides diminutus are probably somewhat older. Among the reworked forms, only $T$. (T.) siakensis is significantly common and in all samples is less abundant than $T$. (T.) acostaensis.

Within the conditions under which DSDP cores are collected, the combined presence of Late Miocene and less common early Middle Miocene faunas should be attributed to reworking rather than downhole contamination. The latter would be a reasonable explanation only if the Late Miocene species were present in just a few samples at the tops and bottoms of cores. Instead, they are consistently 
present throughout the recovered interval and dominate the combined faunas. The unconformity between Cores 12 and 13, which represents the age to which the reworked specimens are referred, indicates the probable availability of nearby contemporaneous outcrops suitable as sources for the reworked fauna.

The upper meter of Core 13, Section 1 contains common Globorotalia (G.) praemenardii and rare Clavatorella bermudezi and is referred to N.10. The remainder of Core 13 and all of Core 14, however, contain relatively nondiverse assemblages in which Globigerinoides sicanus s.l., G. subquadratus, Turborotalia (T.) siakensis, and Globoquadrina spp. are predominant. Catapsydrax stainforthi is absent, and rare specimens of $C$. dissimilis ciperoensis and T. (T.) euapertura are probably reworked. Under these circumstances, no basis for determining whether the samples should be referred to N.7 or N.8 is evident, although technically the absence of $C$. stainforthi is essentially diagnostic for the latter. Age assignments based on species absences are notoriously untrustworthy, however, and as no samples of definite N.6 or N.7 age were recovered below this interval, the broader age interpretation (viz., N.7-N.8) has been made.

Despite the apparent concentration of heavy-walled species, the absolute abundance of planktonic tests is higher in these samples than in any others recovered during Leg 23A. Test fragmentation is conspicuously low. Whether these characteristics result from the selective removal by currents of small forms (including nannofossils), from a substantial decrease in test dissolution, from a combination of both, or from a different cause altogether (e.g., changes in surface-water productivity) could not be determined.

Foraminiferal populations are particularly small and nondiverse in Cores 15 through 16, Section 6, a sequence of Early Oligocene age. Because no samples containing Globoquadrina sellii were recovered above this interval, its absence is not used here as a basis for assigning the samples a P.18 age. Turborotalia (T.) pseudoampliapertura and Subbotina angiporoides, both shown by Blow to become extinct slightly above the P.18/P.19 boundary, occur in this sequence, but their presence is not here considered sufficient for an age determination. The former is very rare and occurs in very few samples, and Berggren (1969a) has reported the latter in Middle Rupelian (middle P.19) assemblages from northern Europe. The samples are thus assigned to the age range of P.18-P.19. It has been decided to recognize the boundary between P.19 and P.20 where the appropriate faunal events were observed in Arabian Sea sediments, largely because the examples from which Blow (1970) concluded that the zones could not be distinguished are all from Atlantic and Caribbean localities. It may be that this boundary can be consistently demarcated only in the Indo-Pacific.

Late Eocene faunas occur in Sample 16, CC through Core 18, Section 2, but an unconformity within Core 17 represents all of Zone N.16. A single specimen tentatively referred to Hantkenina (C.) inflata was found in Core 17, Section 4 , but because this sample lies immediately above the unconformity, the specimen may well be reworked.

Core 18 , Section 3 contains the highest observed typical Middle Eocene faunas characterized by Truncorotaloides pseudodubius and $T$. collacteus. P. 14 assemblages persist as low as Core 19, Section 5; no specimens of Orbulinoides beckmanni or any other species indicative of P.12 or P.13 were noted. The fauna in Core 19, Section 6 includes common Morozovella aragonensis s.s. and Globigerinatheka subconglobata curryi. The absence of $G$. subconglobata euganea is considered significant because of its close relationship, and presumably similar environmental tolerances, with $G$. subconglobata curryi. This association implies a P.11 age and indicates a significant unconformity within Core 19. Several new species of Acarinina and Morozovella range as high as this unconformity and are described in the Systematics section. The top of P.10 is recognized at the highest occurrence of Hantkenina $(H$. mexicana aragonensis in Sample 20, CC.

Cores 22 and 23 penetrated chert containing no preserved fossils, and poor recovery in the remainder of Hole 219 effectively renders the remaining recovered cores a series of isolated samples. Sample 24, CC contains Acarinina soldadoensis s.s. and A. soldadoensis angulosa. Preservation of the fauna, which includes relatively few species, is only fair. The age of this sample may be either P.8 or P.9. The co-occurrence of $A$. convexa with these species suggests a P. 8 age for Core 25 , Section 1; the sparse fauna in Sample 26, CC may be as old as P.7.

A major unconformity was drilled between Sample 26, $\mathrm{CC}$ and Core 27. Samples examined from the latter core contain A. convexa, A. esnaensis, Morozovella acuta, and Globanomalina pseudomenardii, an association typical of upper P.4 (middle Late Paleocene) age. Although planktonic assemblages are uncommon in sediments recovered in Hole 219A, the lowest recovered samples with suitable populations are also assigned to this zone. Core $3 \mathrm{~A}$, approximately 25 meters below Core 27, contains Globanomalina pusilla laevigata and Morozovella angulata with $G$. pseudomenardii, a lower P.4 assemblage. In the lowest well-preserved planktonic faunas (Core 12A, Section 3), these species co-occur with Chiloguembelina crinita, Morozovella $\mathrm{cf}$. woodi, and G. pusilla pusilla. The presence of $G$. pseudomenardii indicates, by definition, an assignment to P.4, but $G$. pusilla s.s. became extinct just above the base of this zone (Berggren, 1968).

The discontinuity described above also represents a period of considerable increase in water depth at Site 219. Planktonic foraminifera dominate all samples in Hole 219 above Core 27 , and the rare benthic species are typical of deep-water assemblages. In samples from Core 27 and Core $3 \mathrm{~A}$ through Core $8 \mathrm{~A}$, Section 1, the remains of bottomdwelling organisms predominate almost to the exclusion of planktonic forms. These include benthic and larger foraminifera, bryozoans, ostracods, and echinoid spines. The benthic species and the general faunal nature are similar to those in Paleocene (Rajagopalan, 1968) rocks exposed at Pondicherry, South India (Samanta, 1968; H. Siddiquie, personal communication) and presumably represent a similar ecologic facies. It seems unlikely that the rocks containing this assemblage were deposited in water depths greater than a few tens of meters.

In Core $8 \mathrm{~A}$, Section 2 through Core $14 \mathrm{~A}$, however, planktonic foraminifera are much more abundant, where preserved, and the remainder of the fossil population 
consists of benthic foraminiferal associations containing forms morphologically similar to Hanzawaia and Cancris. Large Rotalia-like forms of the sort found higher are absent. These faunal suites appear more typical of tropical outer neritic depths, according to the criteria of Bandy $(1960,1964 b)$. The sequence of paleobathymetric events at Site 219 may thus be reconstructed as follows: the site was at outer neritic depth during early P.4 time, but shallowed somewhat later during that zone. This change may have resulted from tectonic movement, but the differences in depth can be accounted for by sediment accumulation. During the late Late Paleocene or early Early Eocene, the site descended to greater, but undetermined, bathyal or abyssal depths.

\section{Site 220}

Cores 1 and 2 at Site 220 contain recognizable but highly dissolved Pleistocene faunas. The remainder of the Neogene (Cores 3 through 5 ) is represented by assemblages so poorly preserved that no zonal assignment can be made with certainty. The presence of Sphaeroidinella dehiscens immatura in Sample 3, CC is the only indication of Pliocene age. Specimens of Streptochilus globigerum in Sample 5, CC suggest a Late Miocene age, although this species first appeared in the late Middle Miocene. Core 5 samples also contain Turborotalia (T.) siakensis, a Middle and Early Miocene species, and on the basis of nannofossil data, Boudreaux (Chapter 4, this volume) has assigned a Middle Miocene age to these samples, with an unconformity within Core 4. Foraminiferal evidence is inadequate to verify or disprove the existence of this postulated lacuna, but on the basis of rare specimens of $T$. (T.) acostaensis just below the "unconformity," the lithologic homogeneity of the sedimentary sequence, the proximity to Site 219, and the apparent unconformity between Cores 5 and 6 , the author prefers to consider the Middle Miocene species in Core 5 as reworked specimens.

In Cores 6 through 10, small Oligocene faunas consist almost entirely of solution-resistant species. The three highest cores, which contain Late Oligocene forms, are tentatively referred to P.22 because of the absence of Turborotalia (T.) opima opima. This species is occasionally present in Cores 9 and 10, of P.20-P.21 (undifferentiated) age. Core 11 contained no foraminifera.

Well-preserved planktonic species are common in lower middle and lower Eocene sediments in Cores 12 through 18 and are associated with generally abundant radiolarians. The considerations involved in the zonation of much of this interval have already been discussed, and additional details are available in the range charts included at the end of this report. The P.8/P.9 boundary lies within the drilled interval between Cores 15 and 16. Planktonic suites in the lower three cores at this site contain Acarinina wilcoxensis, $A$. quetra, and Morozovella aragonensis caucasica and are of P.8 age throughout.

\section{Site 221}

Planktonic foraminifera are largely absent in samples recovered at this site. Very rare, nondiagnostic species of Neogene age occur in occasional samples from Cores 4 through 6 , an interval which also contains several turbidite layers with neritic benthic species (e.g., Buliminella and small Bolivina), as well as rare reworked Eocene specimens. Core 18 contains rare Middle Eocene fossils of solutionresistant forms (Morozovella coronata, Globigerinatheka spp.).

\section{Site 222}

Planktonic foraminifera at Site 222 are rare in most horizons and show considerable evidence of dissolution. Pleistocene assemblages contain, in some cases, moderately diverse if highly concentrated suites of species, but below Core 2 planktonic foraminifera are consistently rare and generally nondiagnostic. Isolated specimens of Globorotalia (G.) tumida tumida as low as Sample 22, CC permitted the recognition of the Miocene-Pliocene boundary, but at no horizon are the faunas sufficiently diverse to allow zone boundaries to be defined.

Much of the sediment recovered at this site represents detrital supply by the Indus River, and transported neritic benthic assemblages are relatively common. These transported faunas, and occasional occurrences of reworked Eocene planktonic species, are largely confined to sedimentary units composed of gray clays and claystones (cf. Chapter 6, this volume). No reworked Cretaceous foraminifera were noted, although nannofossils of this age are common in a number of horizons (cf. Boudreaux, this volume).

\section{Site 223}

Most Neogene planktonic assemblages consist largely of solution-resistant nondiagnostic species, which are particularly rare in the thick upper Miocene to Quaternary sequence sampled in Cores 1 through 16. Planktonic foraminifera are completely absent in most samples from Core 16, Section 4 through Core 20.

These forms are somewhat more common in the early Middle Miocene (N.10 through N.12?) in Cores 21 through 26 . While abundances are higher, however, diversity remains low; the populations are dominated by Turborotalia siakensis, T. (T.) continuosa, and $T$. (T.) mayeri. Core 24, Section 3 contains rare specimens of Globorotalia (F.) praefohsi. Thus, Cores 21 through 24 are no older than N.11 and probably no younger than N.12. The absence of this species in Core 25, coupled with rare occurrences of $G$. (F.) peripheroacuta, prompts the assignment of a basal Middle Miocene (N.10) age to these sediments. Late Early Miocene species in Core 27 include Globigerinoides sicanus s.l. and $G$. diminutus.

All Oligocene zones except P.19 appear to be represented in Core 28 through Core 31, Section 3; the P.21/P.22 boundary is placed within Core 29 at the highest occurrence of $T$. (T.) opima opima. As in higher samples, these populations consist largely of heavy-walled forms. An unconformity within Core 31 results in the superposition of P.18 faunas over P.15 populations containing Globigerinatheka semïnvoluta.

A second unconformity within Core 32, separating Late from Middle (P.12) Eocene populations, may be an artificial feature produced by downhole slumping during drilling, although there is no direct evidence to support this conclusion. These well-developed Middle Eocene faunas 
contain Turborotalia (T.) cerroazulensis pomeroli $(=T$. centralis) and Globigerinatheka subconglobata curryi, but not Morozovella aragonensis s.s. This last species appears with a small and relatively nondiverse assemblage in Core 34, where the presence as well of Subbotina boweri and Turborotalia (T.) cf. bolivariana suggest a P.9-P.10 age assignment.

Below Core 34, planktonic foraminifera are completely absent except in the sidewall core taken just above igneous basement. This sample contains extremely rare and very poorly preserved specimens very tentatively identified as Morozovella cf. angulata, Globanomalina pusilla laevigata, and $M$. cf. aequa. If these identifications are correct, a Late Paleocene (P.4) age is indicated.

\section{Site 224}

The primary objective at this site was the determination of the age of basement rocks. Although a thick sequence was penetrated, few samples were recovered. Planktonic foraminifera are common only in Pleistocene (Core 1) and Eocene (Cores 10 and 11) samples. Core 10 contains abundant and relatively well preserved tests. The co-occurrence of Truncorotaloides pseudodubius and Globigerinatheka index tropicalis justifies the referral of this fauna to P.14 (Bolli, 1972). Morozovella aragonensis s.s. and Acarinina soldadoensis were identified in Sample 11, $\mathrm{CC}$, but the preservation of tests in this sample is so poor that no more precise age determination than Early Eocene is possible.

\section{CONSIDERATIONS OF TAXONOMIC PHILOSOPHY}

In order to successfully apply the study of planktonic foraminifera to the problems of biostratigraphy, micropaleontologists must be continually conscious of dealing with the remains of living organisms. This statement is not the self-evident truism it may appear. The necessity, in the paleontological application of Linnean taxonomy, of fitting a continuously intergrading population of related forms into rigid nomenclatorial categories requires a multitude of subjective decisions concerning the degree of variation tolerable within a species unit. If a sequence of fossil faunas is being considered, the problem is one of defining the taxonomic limits to be placed on an evolving population.

This problem of definition is even more vexing at the generic level in that the difficulties are no longer those of variation about a type. Globorotalia tumida s.s., as the type species, may be representative of the genus Globorotalia, but it is typical only in that at least some of its characteristics are those used by the original author to establish the genus. Any number of elements, including most notably test and chamber shape, coiling pattern, nature of the periphery, wall texture, and nature and location of the aperture, may be considered as characteristic of the type species, but all, in most cases, have been modified through time by evolutionary variation and rarely occur in the same combination in a significant number of species. In practice, the solution to the problem of subjective determination of generic limits has usually been to choose one or a few of these characters and to either ignore the others or assign them subgeneric or specific importance only. This purely morphological approach, which yields a keyed classification system, has the significant advantage that the assignment of species to generic categories becomes relatively simple, if equally arbitrary and artificial.

The two systems of planktonic foraminiferal classification currently in wide use-those of Bolli et al. (1957) and, in particular, of Blow (Banner and Blow, 1959; Blow, 1969)-have employed this approach. In actuality, the substantive differences between these two classifications are few, consisting largely of the assignment of subgenus-level significance to the presence of an imperforate carina and of greater importance to the location and modifications of the aperture. Other characteristics, most notably wall texture, have occasionally been proposed as the bases for classification schemes (e.g., Lipps, 1966), but such systems have not gained widespread approval.

If planktonic foraminifera are truly to be regarded as organisms, and not, in effect, as oddly shaped sand grains, it should be axiomatic that the system of classification must reflect the biological and evolutionary affinities of the species-level taxa, however defined. It is indeed true, as McGowran (1971) has pointed out, that "the fact of evolution is invoked repeatedly in stating the need to use 'basic' and 'less adaptive' characters" (p. 815), and the authors of most classification systems have attempted to demonstrate the evolutionary conservatism of the bases of their generic limits. As the reader has doubtless observed from the genus-species combinations cited in the preceding pages, it is the author's contention here that most such systems, and especially the widely used Blow classification of Tertiary planktonic species, are inadequate in meeting this basic criterion.

In Blow's (1969) classification, for example, all globorotaliform species whose tests possess an imperforate peripheral carina are assigned to the genus and subgenus Globorotalia (Globorotalia). On the basis of evolutionary lineages discussed and cited by Blow (1969; Eames et al., 1962) and by Berggren (1968), it can be demonstrated that $G$. (Globorotalia) has evolved independently in no less than eight separate lineages and sublineages; five of these events occurred during the Neogene alone. For another instance, it is instructive to consider the evolution of "Globigerina pseudoampliapertura" and "G. ampliapertura" from "Globorotalia (Turborotalia) centralis" and "G. (T.) increbescens," respectively, in the Late Eocene (Eames et al., 1962; Blow, 1969). The ancestral and descendent forms are, obviously, very closely related, but because the evolutionary transition involved a slight shift in the position of the aperture, ancestors and descendents are placed in different genera. Neither lineage survived beyond the late Early Miocene, and neither " $G$. ampliapertura" nor " $G$. pseudoampliapertura" is in any significant way related to Globigerina bulloides, the type species of the genus to which they are referred. In a philosophical sense, it is less important whether the two lineages are evolutionarily correct than that Blow believed they were. It can be seen that his system in no way intentionally reflects the evolutionary patterns he recognized. In fairness to Blow, he realized that his "older classification based entirely on gross test morphology" should be used only "on a pro tempore 
basis" (Blow, 1969, p. 313), but it is the author's belief that sufficient evidence was already available to modify that system and that the subsequent widespread use of Blow's classification can be justified only by ignoring much presently available data concerning planktonic evolution that Blow had provided and anticipated.

It is doubtful, indeed, whether gross test morphology alone is inherently capable of providing a biologically justifiable basis for planktonic foraminiferal classification. As a group, planktonic foraminifera have evolved rapidly in a number of divergent patterns from the few species to survive the Cretaceous-Tertiary boundary, and it can be readily shown that certain evolutionary pathways, resulting in particular modifications of gross test form, have been followed independently by several essentially unrelated groups (Cifelli, 1969). Test form is controlled by the organism's response to the environment in which it must survive; thus, similar morphotypes have appeared several times during the Tertiary as adaptations to the recurrence of similar sets of environmental conditions (Frerichs, 1971). Lipps (1966) has lucidly demonstrated that most aspects of gross test morphology can be explained in terms of this environmental pressure. Isomorphism is a fact of life in Tertiary planktonic foraminiferal populations, and any classification system, in order to exclude polyphyletic taxa to the greatest extent possible, must take it into consideration. The inability to distinguish heterochronous or nonheterochronous isomorphism reaches an extreme in one recently published morphological classification (El-Naggar, 1971; the author suggests that internal consistency [p. 426] is "one of its main achievements") in which, for example, the completely unrelated forms Hantkenina spp. (Eocene) and Globigerinella adamsi (late Quaternary) are placed in the same genus because of similar chamber shape.

An alternative but nonetheless essentially morphological basis for classification has been provided by the increased awareness of the importance of surface wall texture (Parker, 1962; Lipps, 1966). Lipps has documented the reasons for considering wall microstructure as an evolutionarily conservative character and distinguished three primary wall types in planktonic tests. This author is in general accord with Lipps's assessment of the stability of this feature, and wall surface texture has played an important role in the generic assignments employed here. Nonetheless, serious reservations about the biological and evolutionary validity of his classification must be maintained. Lipps's study anteceded common use of the scanning electron microscope in the examination and illustration of planktonic tests; thus, his interpretations of wall microstructure have been to some extent contraindicated by subsequent data. His inclusion of Turborotalia centralis and Globorotalia scitula in the same genus (Turborotalia) reflects an inadequate recognition of the significant differences in surface texture between these two species. More seriously, his classification, like Blow's, relies upon "rigid structural hierarchies" (Steineck, 1969) as a basis for generic assignment; the two differ in practice primarily in their choices of definitive morphological criteria, but the underlying taxonomic philosophy is the same. Lipps's classification suffers from an inflexibility which precludes it from reflecting a number of examples of isomorphism, although to a much lesser degree than gross-morphology systems because of the greater evolutionary stability of wall structure. In the Late Eocene evolutionary sequences cited above, for example, rigid application of Lipps's classification would also place the descendent species in a genus (Subbotina) different from the immediately ancestral forms (Turborotalia). As in Blow's system, the former are not directly related to the genus to which they are referred. A second and somewhat opposite result is the recognition of genera (e.g., Eoglobigerina) with long and discontinuous ranges, whose included species contain a common morphologic character but no apparent common evolutionary history.

Any system of classification founded solely on features of test morphology is inherently incapable of fully reflecting the complex interrelationships of Cenozoic planktonic species. To the author's knowledge, for example, there is no significant morphological basis for divorcing Neogloboquadrina dutertrei s.l. from the genus Globoquadrina, but the two groups are completely unrelated except to the extent that most Tertiary planktonic species share a common earliest Paleocene ancestor (Berggren, 1962). In a similar sense, Turborotalia (T.) pseudoampliapertura is essentially inseparable on a morphological basis from Subbotina spp., a taxon to which it can be considered to belong only if Subbotina is placed in synonymy with Turborotalia. Within acknowledged genus groups, morphological considerations alone are frequently incapable of distinguishing important subgroups of related forms. There is no basis, in test characters alone, for separating the Globorotalia fohsi and $G$. cultrata sublineages, although most specialists would agree that these evolutionary sequences were completely independent from the late Early Miocene onward (Blow and Banner, 1966; Olsson, 1972).

It is the author's contention that the sole basis of classification suitable for the representation of biological and evolutionary relationships between planktonic foraminiferal species is the reconstructed phylogeny of these forms. Considering the amount of information currently available concerning planktonic lineages, particularly among Neogene species, the phylogenetic approach to problems of classification has received surprisingly little attention. Bandy et al. (1967) erected the genus Neogloboquadrina for $N$. dutertrei s.l., on the grounds that the ancestry of this species was completely different from that of the genus (Globoquadrina) to which it had been previously referred. McGowran (1971) felt that this "view...perhaps is too extreme for a group showing such strong parallelisms in relatively few characters" (p. 817). Only rarely and recently (Zobel, 1971, 1973; Collen and Vella, 1973) has this generic name been adopted. McGowran (1968) applied the phylogenetic approach to Paleogene globorotaloids. More recently, Steineck $(1969,1971$ b) has proposed a similar reclassification of these forms. Finally, Bandy (1972b) has created a number of subgenera to represent Neogene globorotaloid sublineages. These taxa are based solely on evolutionary considerations.

The proposal of a formal and comprehensive system of phylogenetic classification is unwarranted at this time because of uncertainties in the reconstruction of a number 
of lineages, particularly among Paleogene species. Planktonic foraminiferal evolution is by no means completely understood, and it is to be anticipated that any classification scheme proposed at present would of necessity require modification in response to data obtained by future studies. Where published information is sufficiently detailed and informative, the lineage concept has been applied, and phylogeny has been assigned greater importance, in decisions concerning generic assignment, than arbitrary limits based on gross test morphology. In some cases, where evolutionary sequences are poorly understood, it has been possible to recognize groups of species with a number of morphological traits in common. In no such circumstance, however, has total reliance been placed on a single morphological character. Although detailed lineages cannot as yet be constructed for these forms, each group so considered appears to have undergone an evolutionary development distinct, completely or for long periods of time, from other Cenozoic genera, particularly those to which they have usually been assigned. The most distinct and best known of these species groups has been referred below to "Globigerina;" for another, a new generic name (Tenuitella) is proposed. Finally, for some large groups (including many of the Paleogene forms) species relationships and the significance of morphological features are so poorly known that the convincing delineation of subgroup lineages has not yet proved possible. In these cases, the author has applied the available generic name which he considers to best reflect the evolutionary affinities insofar as they are known, in the expectation that additional research, and in particular extensive illustration of test morphology and wall texture with the scanning electron microscope, will permit further phylogenetic subdivision.

This approach to planktonic foraminiferal taxonomy has been discussed with a number of micropaleontologists during the last few years, and the author, in the course of these discussions, has been confronted with a number of objections. The most serious of these concerns the dangers and difficulties of applying lineage relationships to classification when the evolutionary patterns of planktonic species are incompletely known. This problem has been discussed above and constitutes in part the basis for the decision not to present a formal classification system at this time. This line of argument, however, seems approximately equivalent to proposing, for example, that no use of planktonic foraminifera for biostratigraphy is proper until all problems of zonation details in Cenozoic sequences have been solved. Knowledge of planktonic foraminiferal evolution is indeed incomplete, but this fact does not justify ignoring the considerable volume of data that is available.

The remaining objections relate, for the most part, to the conflict recognized by McGowran (1971) between systematic improvement and classificatory stability: "The systematist tends to be progressive where the nonspecialist and 'applied' specialist tend to be conservative" (p. 813). The primary bases for opposition to phylogenetic taxonomy appear to be that (1) it would result in an unwieldy number of genera and subgenera, with concomitant confusion in application and communication, and that (2) concern with genera is unimportant because the species, not the genus, is the basis of biostratigraphy.
Neither line of reasoning provides a serious obstacle to the utilization of the taxonomic philosophy recommended here. Literally hundreds of Cenozoic planktonic species are currently recognized, of which probably $75 \%$ are generally assigned to either Globigerina or Globorotalia. As a result, these names are meaningless except as an indication, with no phylogenetic implications whatever, of apertural position. It seems unlikely that the confusion resulting from a dozen or so additional generic and subgeneric names could outweigh the benefits to be gained in terms of comprehensibility of the relationships of living and fossil species. It is true, certainly, that the species is the basic unit in the construction and recognition of biostratigraphic zones, although genus-rank taxa may have biostratigraphic significance as well. Berggren (1971a, 1973), however, has emphasized the value of considering Cenozoic biostratigraphy in terms of progressive evolutionary development in a number of separate lineages. The author's experience, during the preparation of this report, has been that the recognition of such lineages has been of great benefit, both tangible and intangible, in developing a sense of Cenozoic evolutionary events and biostratigraphy, and that the consideration of planktonic species in terms of phylogenetic groups has brought a much-heightened sense of order to what otherwise tends to become an unstructured welter of species names.

A comment on wall structure is in order. The surface wall texture types discussed by Lipps (1966) are adopted here, although several additional structural forms appear to be warranted. The wall texture types recognized in the discussions below include:

1) Spinose wall, characterized in living specimens by long acicular spines, which are usually represented in fossils by short spine bases. High-magnification photographs (cf. Globigerina, below) reveal that the wall is fundamentally flat, with spines rising above, and moderately large pores penetrating an otherwise regular and unmodified surface. No distinct pore pits are present.

2) Cancellate wall, characterized by distinct pores located at the center of well-developed depressions (pore pits) separated by relatively narrow ridges. The visual impression created by this wall type is of a regular, reticulate network of intersecting ridges. Spines may be present (e.g., Globigerinoides; Lee et al., 1965) or absent (e.g., Turborotalia), which suggests that further subdivision may be possible. Spines, when present, are localized at ridge intersections.

3) Finely perforate wall (Globorotalia), characterized by pores without recognizable pore pits, distributed in apparently random fashion over a smooth, spineless surface. Many species show small crystallites or short, blunt, spine-like projections in the area of the umbilicus. Under light microscopy, this wall typically appears to be translucent and finely perforate. The pores are considerably more distinct in scanning electron micrographs.

4) Microperforate wall (cf. Globigerinita, below), characterized by extremely small perforations irregularly distributed on an otherwise smooth surface. In G. glutinata, the perforations are approximately $0.6 \mu$ in diameter. Small pustules are common on the test wall of some forms; in 
others, they are limited to certain areas of the test, particularly the umbilical region.

5) Pseudospinose wall, characterized by what appear to be short, blunt spines (cf. Truncorotaloides, below). While this wall type has generally been termed "hispid" or "spinose," the short conical spine-like projections do not appear to have extended into long acicular spines comparable to those found in Globigerina. It seems best to introduce a new term for these Paleogene forms. Moderately large pores are located between the pseudospines, but it does not appear that a regular pattern of pore distribution is typically developed.

In the preparation of the species descriptions and discussions below, most of the holotype illustrations were examined in the Catalogue of Foraminifera (American Museum of Natural History, New York), rather than in the original references. This is particularly true for older species names. Thus in most cases, the publication including the original citation has not been included in the References at the end of this paper.

It is also important to note that the ranges listed for each species refer to the observed stratigraphic distribution in Arabian Sea sequences and not to published records from other geographic areas.

All specimens illustrated in this report, including holotypes and paratypes of all new species, have been deposited in the collections of the U.S. National Museum, Washington, D.C.

\section{SPECIES DESCRIPTIONS}

Genus ACARININA Subbotina, 1953

Type Species: Acarinina acarinata Subbotina.

Remarks: The concept of this genus, as employed here, includes a large group of Paleocene to Middle Eocene species, all of which possess a pseudospinose wall, in which no distinct spinose peripheral carina is developed. Many species are broadly planoconvex or conicotruncate in test form, but great variety in test shape is apparent. Apertural position ranges from umbilical (e.g., Acarinina soldadoensis s.s.) to extraumbilical peripheral (e.g., A. wilcoxensis). This concept is in accord with the manner in which this taxon is employed by most recent authors who have recognized it (McGowran, 1968; Berggren, 1968, 1971a; Blow, 1971).

It is recognized that, as defined in this manner, Acarinina is based to a very large extent on purely morphological criteria. It is unlikely that the genus is as homogeneous as this usage suggests, and in all probability further subdivision will become desirable and possible. It appears, for example, that some difference in wall texture may be present within the species included. The wall surface of $A$. boudreauxi n.sp. and $A$. punctocarinata n.sp. is much less pseudospinose and more coarsely perforate than the wall of such species as A. wilcoxensis (cf. Berggren, 1971 b, pl. 5, figs. 4,5); insufficient evidence is presently available to determine whether such differences warrant genus-level subdivision. Several authors have constructed phylogenetic diagrams for many of the species included in this genus (Berggren, 1968, fig. 4; McGowran, 1968, fig. 1, lineage 3 ), but the sublineages do not appear to be sufficiently reliable as drawn to be used as a basis for taxonomic revision at this time.

McGowran (1968), noting the presence of occasional sutural accessory apertures in several species of Acarinina, the strong similarities in gross test morphology between Acarinina and Truncorotaloides, and the possible polyphyletic origin of the latter genus as generally used, proposed that these two taxa should be separated only at the subgeneric level within the genus Truncorotaloides. This interpretation has been followed by a number of other authors (Steineck, 1971b; Steineck and Gibson, 1971) and may prove to be justified. The author prefers, however, to maintain for the present a separation at the generic level and to restrict Truncorotaloides to forms in which the accessory apertures are a fixed and consistent character, pending a study of the origins and evolution of the few species in that genus.

\section{Acarinina apanthesma (Loeblich and Tappan) \\ (Plate 1, Figure 1)}

Globorotalia apanthesma Loeblich and Tappan, 1957, pl. 59, fig. 1. Stratigraphic Range: This species is generally rare, but occasionally common, in a number of samples of P. 8 and early P.9 age at Site 220.

\section{Acarinina boudreauxi, new species}

(Plate 1, Figures 2, 3, 4, 5)

Description: The test is of moderate size and is subcircular to nearly round in outline, in the form of a planoconvex trochospire with four to five, but typically four and one-half to five, chambers in the final whorl. The subacute to rounded periphery is slightly lobate, particularly along the last two or three chambers. The test wall texture apparently consists of short blunt pseudospines on ventral surfaces; except around the umbilical region, the pseudospines have coalesced into a thick wall penetrated by moderately large pores, and the individual spines are not consistently recognizable. On the dorsal surface, pseudospine development is not evident. The early portions of the trochospire are obscured by the thickened wall and form a low projection above the dorsal plane of the test. The dorsal surface is otherwise nearly flat, but the dorsal chamber walls slope down to the depressed spiral suture along the inner margin of the last whorl forming a shallow but distinct groove. The less distinct, slightly depressed, and nonlimbate dorsal intercameral sutures are tangential and straight, but may be slightly curved along the distal end near the periphery. Ventral sutures are straight, radial, and depressed. The wedge-shaped (in ventral view) chambers increase rapidly in size and in dorso-ventral elevation. The umbilicus is narrow, but deep and distinct. Umbilical shoulders are moderately prominent and have a roughened surface consisting of pseudospines and secondary calcite deposits. In lateral view, the outer chamber walls are moderately inclined, but more steeply so in the last two chambers. The inner walls incline very steeply into the umbilicus. The aperture consists of an extended low arch bordered by an imperforate rim at the base of the somewhat flattened apertural face.

The holotype is illustrated on Plate 1, Figures 2 and 3 , and is from Hole 219 , Core 19 , Section $6,51-53 \mathrm{~cm}$. The age of this sample is early Middle Eocene (Zone P.11; Globigerinatheka subconglobata subconglobata Zone of Bolli, 1972, = Globigerapsis kugleri Zone of Bolli, 1966). Maximum diameter of the holotype is $0.33 \mathrm{~mm}$; axial elevation is $0.25 \mathrm{~mm}$.

Remarks: This form is somewhat similar to a number of other species of Acarinina, including several of those proposed in this report. From A. quetra (Bolli) and A. wilcoxensis (Cushman and Ponton) it may be distinguished by the more compact test and more closely appressed, wedge-shaped chambers in ventral view, the narrower umbilicus, and the less flattened dorsal surface. The rudimentary keel which forms in some specimens of $A$. quetra was not noted in $A$. boudreauxi. It differs from $A$. rotundimarginata Subbotina in having a more rounded and less subquadrate peripheral outline, a more pronounced umbilicus, and a larger aperture, as well as a more distinct spiral suture. It has fewer chambers and a somewhat longer aperture than either $A$. mattseensis (Gohrbandt) or $A$. planodorsalis n. sp. In addition, $A$. boudreauxi has more distinct chambers and ventral sutures than the former and lacks the very distinct dorsal sutures of the latter. It differs from $A$. naussi (Martin) in having a much more rounded periphery and in lacking the strongly tangential dorsal sutures and peripheral accumulation of pseudospines characteristic of that species. Juvenile specimens frequently have a small adventitious final chamber which partially covers the umbilicus. These are somewhat similar to $A$. nicoli (Martin), but are more distinctly planoconvex than that species.

Acarinina boudreauxi is named for Dr. Joseph E. Boudreaux, of Texaco, Inc., a co-participant on DSDP Leg 23.

Stratigraphic Range: P.9 through P.11. 
Acarinina bullbrooki (Bolli)

Globorotalia bullbrooki Bolli, 1957c, pl. 38, figs. 4, 5 .

Remarks: There has been a good deal of taxonomic confusion regarding this species. Berggren (1968) concluded that $A$. bullbrooki should be considered a junior synonym of both "Globigerina spinuloinflata" Bandy, 1949, and "Pulvinulina crassata var. densa" Cushman, 1925. Most authors, following this interpretation, have used "Globorotalia densa" for Bolli's form. The holotypes of the two latter species have recently been illustrated (Cifelli, 1972). Neither Bandy's nor Bolli's specimens are conspecific with Cushman's holotype, which has a much more angular periphery and a narrow but distinct keel. It may prove that $A$. bullbrook $i$ should be considered a junior synonym of $A$. spinuloinflata if the two specimens illustrated by Bolli are conspecific, but the range of variability is not sufficiently known at present to fully justify this conclusion.

Stratigraphic Range: Rare specimens were observed in Zones P.10 and P.11 at Site 219 .

\section{Acarinina convexa (Subbotina)}

(Plate 1, Figure 6)

Globorotalia convexa Subbotina, 1953, pl. 17, figs. 2, 3 .

Remarks: Berggren (1968) and McGowran (1968) have suggested that this species has an evolutionary history separate from that of other pseudospinose acarininids, a conclusion which is not accepted here. The problems involved in the phylogeny of $A$. convexa are discussed in connection with Globanomalina pusilla s.1.

Stratigraphic Range: This species was observed only in the Early Eocene to Paleocene sequences (Cores 25 through $3 \mathrm{~A}$, P. 8 through P.4) at Site 219 and in the lowest recovered P. 8 samples at Site 220.

\section{Acarinina esnaensis (LeRoy)}

Globigerina esnaensis LeRoy, 1953, pl. 6, figs. 8-10.

Globorotalia esnaensis (LeRoy), Loeblich and Tappan, 1957, pl. 61 , figs. $1,2$.

Stratigraphic Range: A. esnaensis was noted only in isolated samples from the shallow water sequence (in Cores 27 through $6 \mathrm{~A}$ ) of P.4 age at Site 219.

\section{Acarinina mattseensis alticonica, new species}

(Plate 2, Figures 1, 2, 3, 4, 5)

Description: The test is small, compact, and rounded in ventral outline, with chambers arranged in a moderately high trochospire. Four and occasionally four and one-half or five chambers are present in the final whorl. The test wall is coarsely perforate with weakly developed pseudospines. These spine-like projections, however, are prominent and distinct in the umbilical region. While the wall is thick, it does not have the appearance of a secondary crust. The chambers are slightly inflated, but the intercameral and spiral sutures are marked only by very low depressions and are indistinct except between the chambers of the final whorl. On the dorsal side, the distinct and elevated trochospire forms a rounded and subconical projection, but the chambers of the early whorls are indistinguishable because of the thickened wall. Dorsal sutures in the final whorl are straight and radial to slightly tangential. The periphery is very broadly rounded and is unrecognizable as a distinct region. The umbilicus is usually distinct and nearly round to subquadrate, but in some specimens (Plate 2, Figure 4) it may take the form of an irregular elongate slit. Ventral sutures are somewhat depressed and slightly more distinct than those on the dorsal surface, and in ventral view the chambers are subglobular. The aperture is a low-arched opening within the umbilicus at the base of the apertural face.

The holotype is illustrated on Plate 2, Figures 1,2 , and 3 and is from Hole 229, Core 16, Section 2, 68-70 cm. The age of this sample is Early Eocene (P.8, Globorotalia aragonensis Zone of Bolli, 1966). Maximum diameter of the holotype is $0.31 \mathrm{~mm}$ and axial elevation is $0.30 \mathrm{~mm}$.

Remarks: A. mattseensis alticonica n.sp. is somewhat similar, in overall form, to Globigerinatheka senni (Beckmann) (pl. 8, figs. 10, 11). The wall in the former is much less thickened and crystalline and does not have the crust-like appearance which led Beckmann (1953) to assign his species to Sphaeroidinella. The chambers in $G$. senni are somewhat more distinct, and the pustules around the umbilicus much more pronounced than in A. mattseensis alticonica. The latter species is also typically considerably smaller. Although $A$. mattseensis alticonica appears one zone earlier than $G$. senni, the similarity of the two forms should probably be considered isomorphic in nature. Evidence presented in connection with $G$. senni suggests that it evolved from a different form altogether.

The wall structure and test shape of $A$. mattseensis alticonica are roughly similar to that of $A$. mattseensis s.s. (Gohrbandt), from which it differs in having more chambers and a higher dorsal coil. Gohrbandt (1967) suggested the evolution of the latter taxon from A. broedermanni (Cushman and Bermudez) near the Early-Middle Eocene boundary. It appears likely, however, that $A$. mat tseensis s.s. and $A$. mattseensis alticonica are closely related, and the latter may have given rise to the former. A. mattseensis wartsteinensis (Gohrbandt) evolved from the nominate subspecies as a continuation of the apparent trend toward flattening of the dorsal surface and increasing number of chambers in the final whorl.

The subspecies name alticonica refers to the distinctive and characteristic high trochospire.

Stratigraphic Range: This species is found only in samples of P.8 age at Site 220 , where it is common.

\section{Acarinina mattseensis mattseensis (Gohrbandt) \\ (Plate 1, Figures 7,8)}

Globorotalia mattseensis Gohrbandt, 1967, pl. 1, figs. 25-30.

Remarks: The specimens observed here correspond well to the concept described and illustrated by Gohrbandt (1967). The method for distinguishing this form from $A$. mattseensis alticonica is discussed above. It is differentiated from $A$. mattseensis wartsteinensis primarily by its less-flattened dorsal side and fewer chambers per whorl.

Stratigraphic Range: P.8 to P.11 at Site 220 only.

\section{Acarinina mattseensis wartsteinensis (Gohrbandt)}

Globorotalia wartsteinensis Gohrbandt, 1967, pl. 1, figs. 18-24.

Remarks: The proposed phylogenetic relationships and distinguishing characters of this subspecies are discussed above in remarks concerning the other subspecies of this group, as well as by Gohrbandt (1967). It should be noted that Gohrbandt's species have not been widely reported, and their full stratigraphic distribution and range of morphologic variation are not known.

Stratigraphic Range: Late P.9 to early P.11, primarily at Site 220. An isolated and questionable occurrence was noted in Hole 219, Core 21 (P.10).

\section{Acarinina pentacamerata (Subbotina)} (Plate 1, Figure 9)

Globorotalia pentacamerata Subbotina, 1947, pl. 7, figs. 12-17. Acarinina pentacamerata (Subbotina), Subbotina, 1953 (1971), pl. 23 , fig. $8 ;$ pl. 24 , figs. 1-6.

Stratigraphic Range: P.8 through basal P.10, Site 220.

\section{Acarinina planodorsalis new species}

(Plate 2, Figures 6, 7, 8, 9; Plate 3, Figures 1, 2)

Description: The small to medium-sized planoconvex test consists of at least 11 chambers arranged in a low trochospire, with 6 to 8 chambers in the final whorl. The ventral cameral walls consist of short pseudospines whose interconnected bases separate common and relatively large pores. The development of pseudospines is most pronounced around the umbilicus, but these features are poorly developed or absent on the dorsal surface (Plate 3, Figure 2) except over the obscured early whorls. The spiral surface is nearly flat, but the early chambers form a broad low projection. The dorsal sutures are strongly depressed and curved, particularly in the distal portion of each suture. The anterior margin of each chamber projects above the posterior region of the following chamber, giving a slightly imbricate appearance to the dorsal surface. The chambers and sutures, as a result, are quite distinct in dorsal view, particularly in the final whorl. The slightly lobate periphery is subacute in the early portions of the final whorl and rounded on the last few chambers. The ventral surfaces of each chamber slope gradually from the periphery to the edge of the umbilicus, but the steepness of inclination increases throughout the final whorl. Ventral sutures are straight and somewhat depressed, especially near the umbilicus, 
where they appear as narrow, deeply incised channels. The rounded umbilical shoulders are roughened by the increased development of coarse pseudospines. The umbilicus varies from broad to narrow, but is generally distinct. The aperture is a low arch near the center of the base of the apertural face. No distinct apertural lip is present.

The holotype is illustrated on Plate 2, Figures 6, 7, and 8. It was recovered from Hole 219, Core 29, Section 4, 52-54 cm. The age of this sample is early Middle Eocene (P.11; Globigerinatheka subconglobata subconglobata Zone of Bolli, 1972, = Globigerapsis kugleri Zone of Bolli, 1966). Maximum diameter of the holotype is $0.35 \mathrm{~mm}$; axial elevation is $0.21 \mathrm{~mm}$.

Remarks: $A$. planodorsalis is similar in form to $A$. nicoli (Martin), but differs in having more chambers per whorl and more distinct dorsal sutures. It also resembles $A$. mattseensis wartsteinensis from which it appears to have evolved. It may be separated from this latter form by its less-elevated ventral surface, flatter dorsal side and more distinct dorsal sutures, and the channelled ventral sutures in the umbilical region.

The species name refers to the flattened dorsal surface.

Stratigraphic Range: Middle P. 10 to P. 11.

\section{Acarinina pseudotopilensis Subbotina}

Acarinina pseudotopilensis Subbotina, 1953, pl. 21, figs. 8, 9; pl. 22 , figs. 1-4.

Stratigraphic Range: Rare specimens of this species were found only in Sample 220-19-2, 45-47 cm (P.8)

\section{Acarinina punctocarinata, new species (Plate 3, Figures 4, 5, 6, 7, 8)}

Description: The distinctly planoconvex test of Acarinina punctocarinata is of moderate size for the genus. Chambers are arranged in a low trochospire with four to five in the final whorl. The test outline is typically subquadrate, although small specimens may be rounded. Cameral walls are coarsely perforate but not cancellate. No pore pits, with diameters significantly larger than the pore itself, are apparent. Short blunt pseudospines are developed only on and near the umbilical shoulders and along the periphery. The dorsal surface is distinctly flattened, but the early chambers, obscured by thickening of the wall, are slightly elevated. Dorsal intercameral sutures are strongly curved and depressed, particularly between the last few chambers, which are arcuate or lunate in shape. The proximal chamber walls in the final whorl slope downward toward the depressed spiral suture, which forms a broad but distinct groove separating the final whorl from earlier formed chambers. The periphery is slightly lobate and subacute throughout the last whorl. A distinct and thickened pseudocarina composed of coalesced pseudospines is present along the peripheral margin and may extend a short distance along the dorsal intercameral sutures. This pseudocarina, however, contains large, readily observed, and irregularly distributed pores. The outer ventral chamber walls are steeply inclined from the umbilical shoulders to the periphery; the steepness increases throughout the final whorl. Ventral sutures are straight and depressed. The chambers are broadly wedge-shaped in ventral view and increase markedly in size in the final whorl. The umbilical shoulders are prominent and appear roughened because of the greater development of pseudospines. The umbilicus is relatively narrow, but open and deep. The umbilical to extraumbilical aperture forms a low to moderately open arch at the base of the apertural face and is bordered by a faint rim.

The holotype is illustrated on Plate 3, Figures 4, 5, and 6, and is from Hole 220, Core 12, Section $5,70-72 \mathrm{~cm}$. The age of this sample is early Middle Eocene (P.11; Globigerinatheka subconglobata subconglobata Zone of Bolli, 1972= Globigerapsis kugleri Zone of Bolli, 1966). The maximum diameter of the holotype is $0.39 \mathrm{~mm}$; axial elevation is $0.28 \mathrm{~mm}$.

Remarks: This species differs from A. quetra (Bolli) in having more closely appressed and less-rounded chambers, a more prominent development of peripheral thickening, and a distinct groove along the spiral suture. The pseudocarina distinguishes $A$. punctocarinata from other known early Middle Eocene species.

This species is placed in Acarinina, rather than Morozovella, on the basis of overall test form and of the coarsely punctate character of the pseudocarina, which appears to differ fundamentally in nature from the keel observed in typical morozovellids. The species name refers to this coarsely perforate peripheral thickening, which is distinctive in this form.

Stratigraphic Range: P.10 to P.11 (early Middle Eocene).

\section{Acarinina quetra (Bolli) \\ (Plate 3, Figure 3)}

Globorotalia quetra Bolli, $1957 \mathrm{a}, \mathrm{pl}$. 19, figs. 1-6.

Remarks: Bolli (1957a) noted the presence of a keel on some specimens. On the basis of that feature, Blow (1971) referred this species to Morozovella (treated by him as a subgenus of Globorotalia; p. 1019). The author agrees with Berggren (1968) that, in view of the relationships indicated by test form, the rudimentary keel on these forms is not of generic or subgeneric level taxonomic significance.

Stratigraphic Range: This species was observed only in the lower recovered samples of P. 8 age at Site 220 .

\section{Acarinina soldadoensis angulosa (Bolli)}

(Plate 4, Figure 1)

Globigerina soldadoensis angulosa Bolli, 1957a, pl. 16, figs. 4-6.

Remarks: The author has examined the holotype of this species and concluded that the forms observed here, while not identical with that specimen, clearly belong within this taxon. In the holotype, the umbilical shoulders are distinctly angular, and the inner walls of the chambers in the final whorl are flattened and very steep. These characters are difficult to determine from Bolli's illustration. This angular umbilical margin is characteristic of the forms here identified as $A$. soldadoensis angulosa, but is not as fully developed as on the holotype.

Stratigraphic Range: P.8 to P.9 at Site 220.

\section{Acarinina soldadoensis soldadoensis (Brönnimann) (Plate 4, Figure 2)}

Globigerina soldadoensis Brönnimann, 1952, pl. 1, figs. 1-9. Globigerina soldadoensis Brönnimann, Bolli, $1957 \mathrm{a}$, pl. 16, figs. 7-9. Acarinina soldadoensis (Brönnimann), Berggren, 1971b, pl. 5, figs. $1-3$.

Remarks: The holotype, as illustrated by Brönnimann (1952), appears to be fully typical of the specimens encountered in Arabian Sea sediments. Bolli's specimen seems to be conspecific with the type concept, but is probably atypical.

Stratigraphic Range: P.8 to P.11, Site 220 .

\section{Acarinina wilcoxensis (Cushman and Ponton)}

Globorotalia wilcoxensis Cushman and Ponton, 1932, pl. 9, fig. 10. Globorotalia wilcoxensis Cushman and Ponton, Bolli, 1957a, pl. 19, figs. 7-9.

Acarinina wilcoxensis (Cushman and Renz),[sic], Berggren, 1971b, pl. 5 , figs. 4,5 .

Truncorotaloides wilcoxensis (Cushman and Ponton), Steineck, 1971 b, fig. 5 .

Remarks: Bolli's specimen shows agreater ventralinflation of the chambers in the final whorl than does the holotype as illustrated. The specimens observed here are somewhat intermediate, in terms of this character, between these two forms.

Stratigraphic Range: P. 8 at Site 220.

\section{Genus CANDEINA d'Orbigny, 1839}

Type Species: Candeina nitida d'Orbigny.

Remarks: Blow (1969) has discussed the origins of this genus from Globigerinita glutinata parkerae (Globigerinoides parkerae of Blow), and the author agrees with this conclusion. The similarity in wall texture between these two groups can be observed in Blow's illustrations of "Globigerinoides" parkerae and Candeina nitida praenitida (1969, pl. 22) and by comparing his illustration of the wall of the latter (pl. 22, fig. 8) with that of Globigerinita glutinata s.s. (pl. 9, fig. 2, this report).

Candeina nitida nitida d'orbigny

Candeina nitida d'Orbigny, 1839 , pl. 2, figs. 27, 28 .

Stratigraphic Range: N.17 to N.23. 


\section{Candeina nitida praenitida Blow}

Candeina nitida praenitida Blow, 1969 , pl. 22, figs. 5-8.

Remarks: Blow (1969) has discussed the manner in which these two subspecies may be distinguished. While somewhat arbitrary, his criteria are relatively easy to apply and have been followed here.

Stratigraphic Range: N.17 to early N.18, Site 219. This form has been recorded (Blow, 1969) in sediments as old as late N.15, but no upper Miocene sediments with well-preserved faunas older than N.17 were recovered during this cruise.

\section{Genus CASSIGERINELLA Pokorný, 1955}

Type Species: Cassigerinella boudecensis Pokorný (= junior synonym of Cassidulina chipolensis Cushman and Ponton).

Remarks: The origins of this genus are essentially unknown. The wall texture and biserial (although enrolled) chamber arrangement are somewhat similar to those observed in Chiloguembelina spp. However, the early planispiral stage noted in the oldest known species, Cassigerinella winniana (Howe) $(=C$. eocaena Cordey) by Cordey (1968), and the presence of a toothplate in C. chipolensis (Hofker, 1963; Steineck and Darrell, 1971), suggest that these forms may not properly belong in the Globigerinacea.

\section{Cassigerinella chipolensis (Cushman and Ponton)} (Plate 4, Figure 3)

Cassidulina chipolensis Cushman and Ponton, 1932, pl. 15, fig. 2.

Remarks: No tooth plates were noted in specimens examined from Arabian Sea sediments, largely because the apertures were consistently filled with fine-grained sediment.

Stratigraphic Range: Rare specimens were observed in isolated samples from the Early-Middle Oligocene (P.18-P.19) and late Early Miocene (N.7-N.8) at Site 219. At this site, occasional reworked specimens were also noted in upper Miocene sediments.

\section{Genus CATAPSYDRAX Bolli, Loeblich, and Tappan, 1957}

Type Species: Globigerina dissimilis Cushman and Bermudez.

Remarks: The genus Catapsydrax was originally recognized on the basis of the small umbilical bulla with few accessory apertures, as opposed to the extensive bulla with numerous accessory apertures of Globigerinita (Bolli, et al., 1957). Banner and Blow (1959), in their reclassification of the Globigerinacea, accepted this distinction, but subsequently (Eames et al., 1962) concluded that "these distinctions are of no more than specific character ..." (p. 104). Most subsequent authors (Blow, 1969; Brönnimann and Resig, 1971; Jenkins and Orr, 1972; Poag, 1972; Bolli, 1972) appear to have followed this interpretation.

The recombination of these two genera, however, can be accomplished only by overlooking the significant differences in wall texture, stratigraphic distribution, and phylogeny which distinguish Catapsydrax and Globigerinita. In fact, they include completely unrelated but grossly isomorphic groups of species.

The differences in wall texture can be noted by comparing the walls of Globigerinita glutinata s.s. (Plate 9, Figure 2) and Catapsydrax dissimilis s.s. (Plate 4, Figure 5, this report; Blow, 1969 , pl. 25, figs. 6, 7). The basic plan of the wall of G. glutinata is a smooth, flat surface. Penetrating this surface are very numerous and extremely small $(0.6 \mu)$ pores, which are irregularly distributed. It is important to note that no pore pits are developed. Projecting from the surface, and in part covering and obscuring the minute perforations, are abundant small pustules or crystallites, which average approximately $5 \mu$ in diameter. There are no indications of spines or spine bases, nor of a cancellate surface network.

The surface wall texture in $C$. dissimilis s.s., by contrast, is completely different. As in all other species referred here to Catapsydrax, the wall is cancellate; the pores are much larger, and are located within distinct pore pits. In effect, there are no similarities of consequence between the two wall types; the differences are readily visible under the light microscope.

The stratigraphic distribution and evolution of the two genera are equally distinct. Catapsydrax is largely a Paleogene group and reaches its maximum diversity ( 7 species-rank taxa) during the middle Oligocene. The earliest known species is $C$. dissimilis s.s. ("Catapsydrax" echinatus Bolli is not included because of its apparently spinose wall) which probably evolved from Globorotaloides suteri during the late Middle Eocene. A few species range into the late Early Miocene, but with $C$. stainforthi the genus became extinct near the top of N.7.

Although it first appeared during the Late Oligocene, Globigerinita is predominantly a Neogene genus. Jenkins (1965b) has convincingly documented its evolution from "Globorotalia (Turborotalia) munda" (Tenuitella munda of this report) by tracing the transition from an extraumbilical to an umbilical aperture in "Globigerina juvenilis" (Globigerinita boweni of this report). That the two have the same wall texture can be observed by comparing the wall of $G$. boweni (Plate 9, Figure 4, this report) with that of Tenuitella munda (cf. Jenkins, 1965b, p. 1121-1122 and fig. 14). Globigerinita boweni subsequently evolved into G. glutinata s.1., the primary Neogene bullate stock. Thus, the stratigraphic overlap of bullate forms with these two fundamentally different wall textures is limited to a relatively short interval, i.e., the latest Oligocene and part of the Early Miocene.

From this evidence, it can be seen that Catapsydrax and Globigerinita are completely distinct groups of species. They evolved at different times from separate and unrelated ancestors; have different, if slightly overlapping, stratigraphic ranges; and differ strikingly in wall texture. In short, these two genera have completely distinct phylogenetic histories and are readily distinguished on the basis of primary morphological considerations. In accordance with the taxonomic concepts presented in the previous section, these two genera must be treated as separate and distinct taxa.

The strong similarities in gross test morphology illustrate the dangers inherent in applying universally, as a basis for classification, a single arbitrarily determined character, in this case the nature of apertural modification. In this context, Blow (1969) failed to recognize one of the more striking examples of isomorphism in overall test form. He erected the subspecies Globigerinita stainforthi praestainforthi (pl. 25, figs. 3-5) which he distinguished from the nominate subspecies (pl. 25, figs. 8-10) primarily on the basis of slight differences in coiling and the nature of the bulla. In fact, these two subspecies of "Globigerinita" stainforthi are completed unrelated. G. stainforthi praestainforthi has a wall with very small perforations, not visible in the holotype illustration, and abundant pustules, as compared to the cancellate wall of Catapsydrax stainforthi. Blow recognized the difference in wall texture, and accorded it subspecific status only. It can readily be seen that Blow's holotype is nearly identical with the form identified by Jenkins and Orr (1972, pl. 27, fig. 8 only) as Globorotalia cf. minutissima except for the presence of the bulla. Both forms would be placed here in Tenuitella. In view of the clear phylogenetic relationship, the presence of the bulla should be given no more than species-level significance.

\section{Catapsydrax africanus (Blow and Banner)}

Globigerinita africana Blow and Banner, in Eames et al., 1962, pl. 15 , figs. A, B.

Remarks: In the original description, the wall of $C$. africanus was described as "uniformly and moderately coarsely perforate; its surface is punctate and distinctly, densely and finely hispid" (p. 106). The few specimens observed in the Arabian Sea samples are typically cancellate, and no evidence of hispidity was noted. They are otherwise identical in test morphology with the holotype. It would appear that Blow and Banner interpreted the nodes formed at the intersections of interpore ridges as spine bases, but their description of uniform coarse perforations suggests that the holotype has a cancellate wall. It is not known whether Catapsydrax species were spinose when living. If so, the holotype of this species may be a particularly well preserved specimen. On the other hand, it appears that Catapsydrax evolved from Globorotaloides. The only living representative of this latter genus, $G$. hexagonus, is nonspinose (Parker, 1962),

Stratigraphic Range: Very rare specimens were found in a few samples from Core $219-18$, of P.14 to P.15 age.

\section{Catapsydrax dissimilis ciperoensis (Blow and Banner)} (Plate 4, Figure 4)

Catapsydrax dissimilis (Cushman and Bermudez), Bolli et al., 1957, pl. 7 , fig. 8 only. 
Globigerinita dissimilis ciperoensis Blow and Banner, in Eames et al., 1962 , pl. 14, figs. A, B, C.

Globigerinita dissimilis ciperoensis Blow and Banner, Blow, 1969, pl. 24 , fig. 2.

Remarks: It may be that there are slight differences in wall thickness and texture between this and the nominate subspecies. Poag (1972) has raised this taxon to the status of a separate species. It is tentatively maintained here at the subspecific level only. The basis upon which it may be distinguished from $C$. dissimilis s.s., a difference in the nature of the bulla, is described adequately by Blow (1969).

Stratigraphic Range: This species is represented by rare, probably reworked specimens in Zone N.7-N.8 at Site 219, and by occurrences in Zone P.22 at Sites 220 and 223.

\section{Catapsydrax dissimilis dissimilis (Cushman and Bermúdez)} (Plate 4, Figure 5)

Globigerina dissimilis Cushman and Bermúdez, 1937, pl. 3, figs. 4-6. Catapsydrax dissimilis (Cushman and Bermúdez), Bolli et al., 1957, pl. 7, figs. 6,7 only.

Globigerinita dissimilis dissimilis (Cushman and Bermúdez), Blow and Banner, in Eames et al., 1962, pl. 14, fig. D.

Stratigraphic Range: This species occurs only rarely in samples of P.22 age at Sites 220 and 223.

\section{Catapsydrax globiformis (Blow and Banner)} (Plate 4, Figure 6)

Globigerinita globiformis Blow and Banner, in Eames et al., 1962, pl. 14, figs. S, T, U.

Remarks: The comments on wall texture included under $C$. africanus apply to this species as well.

Stratigraphic Range: Very rare specimens were observed within Zone P.15 at Site 219.

\section{Catapsydrax martini (Blow and Banner)}

Globigerinita martini martini Blow and Banner, in Eames et al., 1962, pl. 14, fig. O.

Stratigraphic Range: A single specimen was observed in Sample 219-16-3, of P.18-P.19 age.

\section{Catapsydrax perus (Todd)}

(Plate 4, Figure 7)

Globigerina pera Todd, 1957, pl. 70, figs. 10, 11 .

Globigerinita pera (Todd) Blow and Banner, in Eames et al., 1962, pl. 14, figs. E, F, G, H.

Stratigraphic Range: Late P.14 to P.22.

Catapsydrax unicavus primitivus (Blow and Banner)

Globigerinita unicava primitiva Blow and Banner, in Eames et al., 1962 , pl. 14, figs. J, K, L.

Remarks: There appears to be some confusion about the manner in which this subspecies should be distinguished from $C$. unicavus s.s. Blow and Banner stated that $C$. unicavus primitivus differs "in possessing more strongly vaulted ventral surfaces to the primary chambers, [and] a more inflated bulla" (Eames et al., 1962, p. 114). Subsequently, Blow (1969) distinguished this subspecies by its "less inflated bulla and more embracing but less inflated primary chambers ... as compared to G. unicava unicava" (caption for pl. 25 , figs. 1,2 ). In each case, the illustrated specimen is in accord with the description. The earlier concept, associated with the holotype, has been followed here.

Stratigraphic Range: P.17 to P.20-P.21, consistently only as rare specimens.

\section{Catapsydrax unicavus unicavus Bolli, Loeblich, and Tappan}

Catapsydrax unicavus Bolli, Loeblich, and Tappan, 1957, pl. 7, fig. 9.

Globigerinita unicava unicava (Bolli, Loeblich, and Tappan), Blow and Banner, in Eames et al., 1962, pl. 14, figs. M, N.

Remarks: See comments included for $C$. unicavus primitivus.

Stratigraphic Range: This species is occasionally present as very rare and isolated specimens in Zones P.18-P.19 to P.22.
Genus CHILOGUEMBELINA Loeblich and Tappan, 1956

Type Species: Guembelina midwayensis Cushman.

Remarks: This genus has been inadequately studied, from a biostratigraphic point of view, probably because of the small size of most species and their scarcity in Cenozoic planktonic assemblages. Little attention appears to have been accorded these forms in published studies subsequent to that of Beckmann (1957), and the stratigraphic ranges are thus poorly known.

\section{Chiloguembelina crinita (Glaessner)}

Guembelina crinita Glaessner, 1937, pl. 4, fig. 34.

Chiloguembelina crinita (Glaessner), Beckmann, 1957, p1. 21, fig. 4.

Stratigraphic Range: This species is present only as rare specimens in several samples from Hole 219A (P.4).

\section{Chiloguembelina cubensis (Palmer)}

(Plate 4, Figure 8)

Guembelina cubensis Palmer, 1934, figs. 1-6.

Chiloguembelina cubensis (Palmer), Beckmann, 1957, pl. 21, fig. 21. Chiloguembelina spp. ex group cubensis (Palmer), Blow, 1969, pl. 54, figs. 4-6.

Stratigraphic Range: Latest P.10 to P.18-P.19 at Site 219.

\section{Chiloguembelina midwayensis (Cushman)}

Guembelina midwayensis Cushman, 1940, pl. 11, fig. 15 .

Chiloguembelina midwayensis (Cushman), Beckmann, 1957, pl. 21, fig. 1.

Stratigraphic Range: Very rare specimens were observed in Hole 219A, Cores 8, Section 5 and Core 12, Section 3 (P.4 age).

Chiloguembelina wilcoxensis (Cushman and Ponton)

Guembelina wilcoxensis Cushman and Ponton, 1932, pl. 8, figs. 16, 17.

Chiloguembelina wilcoxensis (Cushman and Ponton), Beckmann, 1957 , pl. 21 , figs. $10,12,13$.

Stratigraphic Range: A single, poorly preserved specimen was found in Sample 219A-3-1, of P.4 age.

\section{Genus CLAVATORELLA Blow, 1965}

Type Species: Hastigerinella bermudezi Bolli.

Remarks: Considerable confusion has prevailed in the published literature concerning the proper generic assignment of the single species assigned to this genus. $H$. bermudezi was initially assigned to Hastigerinella on the basis of the radially elongate chambers (Bolli, $1957 \mathrm{~b})$, and this practice has been followed by some subsequent authors (e.g., Jenkins and Orr, 1972). The undesirability of employing chamber elongation as a basis for a generic assignment has been discussed previously. A comparison of the wall texture, coiling pattern, spine development, and apertural characteristics in $H$. bermudez $i$ with those of the type species, $H$. rhumbleri Galloway $=H$. digitata (Rhumbler) (cf. Jenkins and Orr, 1972, pl. 38, figs. 1-3 and pl. 37, figs. 4-6; cf. also Banner and Blow, 1960a, figs. 7, 8) reveals that there are no other points of essential similarity. In particular, $H$, rhumbleri lacks the distinct cancellate wall texture of $H$. bermudezi.

Lipps (1964) erected the genus Protentella (type species, $P$. prolixa Lipps) and subsequently (Lipps, 1966) included $H$. bermudezi Bolli as one of the species to be assigned to it. The nature and affinities of $P$. prolixa have been subject to some dispute, and neither the genus nor the type species has been widely recognized. Blow (1965) suggested that Protentella should be considered a junior synonym of Bolliella Banner and Blow, that $P$. prolixa might be a junior synonym of $B$. adamsi, and that, in any case, the age of the specimens is probably younger than Middle Miocene. There is little justification for any of these conclusions. The Middle Miocene age of the Luisian stage sediments from which $P$. prolixa was originally collected has been firmly established (Bandy and Ingle, 1970 ), and B. adamsi (= Globigerinella adamsi of this report) is limited in age to the late Quaternary (Blow, 1969). The possibility of natural contamination is precluded by the absence of G. adamsi in the cool waters of the offshore region near Newport Bay, California (the topotype locality). Topotype specimens of $P$. prolixa illustrated here (Plate 5, Figures 3, 4, 5, 6) show this species to be completely different from G. adamsi; it is much smaller, has a larger, more open 
aperture, and lacks the distinctly spinose wall of the latter form. It is quite different, as well, from Clavatorella bermudezi, particularly in the nature of the wall. The very small and abundant pores lack the distinct pore pits and the surrounding well-developed cancellate ridge pattern of Bolli's species. The wall in C. bermudezi is thick and opaque. In $P$. prolixa, it is very thin and translucent and appears nearly imperforate under reflected light. $C$. bermudezi is distinctly and strongly trochospiral, although the spire is very low, and the aperture is umbilical to extraumbilical in position. In adult specimens of $P$. prolixa, the test is very nearly, if not quite, planispiral, and the aperture is distinctly peripheral. In view of the differences in wall texture, and to a lesser degree those of coiling pattern, Protentella and Clavatorella should be considered as separate and unrelated genera.

Blow (1965) considered Clavatorella to have evolved from a globorotaliid ancestor and later (1969) considered this taxon to be a subgenus of Globorotalia s.l. There does not appear, however, to be a-globorotaliid form with suitable test morphology and stratigraphic range that could be recognized as an ancestral species. On the other hand, $C$. bermudezi is quite similar in form to Globorotaloides variabilis, from which it differs only in the radial elongation of the last one or two chambers and in the more elongate aperture. The similarity is striking in forms lacking the late-stage chamber elongation (Plate 5, Figure 1, this report; Jenkins and Orr, 1972, pl. 38 , figs. 1, 2). The forms illustrated by Jenkins and Orr show a development of the umbilical apertural position typical of the adult stage in Globorotaloides spp. These characters and the coarsely cancellate wall texture of both forms indicate that Clavatorella evolved in the latest Early Miocene from Globorotaloides variabilis. There are no other known descendent species with the features typical of Clavatorella, and while the author has retained for the present the taxonomic separation of this genus, it should perhaps be distinguished from Globorotaloides only at the subgeneric level.

\section{Clavatorella bermudezi (Bolli)}

(Plate 5, Figures 1, 2)

Hastigerinella bermudezi Bolli, 1957b, pl. 25, fig. 1.

Clavatorella bermudezi (Bolli), Blow, 1965, figs. 1-5.

Protentella bermudezi (Bolli), Lipps, 1966, p. 1269

Globorotalia (Clavatorella) bermudezi (Bolli), Blow, 1969, pl. 40,

figs. 8,9 ; pl. 41 , figs. $1-4$.

Remarks: See comments for Clavatorella, above.

Stratigraphic Range: Occasional specimens were found only in Sample 219-13-1, of early Middle Miocene (N.10) age.

\section{Genus GLOBANOMALINA Haque, 1956}

Type Species: Globanomalina ovalis Haque (= junior synonym of Globorotalia chapmani Parr).

Remarks: A number of finely perforate globorotaliform species of Paleogene age are included in this genus, which is broadly isomorphic with the purely Neogene genus Globorotalia. Most authors have referred these species to the latter taxon (e.g., Bolli, 1966; Blow, 1971), but despite the striking similarities in overall test morphology, there is no indication of a phylogenetic relationship of any significant extent between Globanomalina and Globorotalia. Species assigned to the former have been recorded no higher than Zone P.14, although the recognition here of Globanomalina laccadivensis $\mathrm{n}$. $\mathrm{sp}$. extends the range of this genus into the Late Eocene. Globorotalia, as recognized here, evolved no earlier than Early Miocene; throughout the Oligocene, there is no smooth-walled (i.e., finely perforate) species which can be included in either taxon, and there is no known evolutionarily intermediate form. These two genera thus represent independent but roughly isomorphic lineage groups with different geologic ranges and with no stratigraphic overlap. On the basis of phylogenetic considerations, it is clear that the genus name Globorotalia cannot be properly applied to the Paleogene species.

McGowran (1968, lineage 6) recognized the evolutionary basis of this distinction and referred these species to Planorotalites Morozova, an interpretation followed by several other authors (Jenkins, 1971; Berggren, 1971a). Globanomalina, in his reclassification, was reserved for planispiral forms referred here to Pseudohastigerina Banner and Blow. Reexamination of the holotype of the type species of Globanomalina, G. ovalis Haque, has demonstrated
(Berggren et al., 1967) that this specimen is slightly trochoid rather than planispiral, and Haque's species should thus be considered a junior synonym of Globorotalia chapmani Parr. Globanomalina, which has priority over Planorotalites, is therefore the oldest available generic name applied to this lineage, and following Steineck (1971), it has been adopted here.

Blow (1971) has subdivided these species into subgenera (within Globorotalia) on the basis of the presence or absence of an imperforate keel. This feature appears to be of particularly minor importance with respect to this group. If Berggren's (1968) lineage 2 is correctly drawn, it has appeared at least twice during the phylogeny of Globanomalina.

\section{Globanomalina chapmani (Parr)}

Globorotalia chapmani Parr, 1938, pl. 3, figs. 8, 9 .

Globanomalina ovalis Haque, 1956, pl. 14, fig. 3.

See Berggren et al., 1967, p. 277, for additional synonymy.

Stratigraphic Range: Rare specimens of $G$. chapmani were observed in the shallow-water sediments recovered in Hole 219A (P.4 age).

Globanomalina laccadivensis, new species

(Plate 5, Figures 7, 8, 9, 10, 11,12)

Description: The minute strongly compressed test contains at least 14 chambers arranged in a very low trochospire, with $5 \frac{1}{2}$ to $6 \frac{1}{2}$ chambers in the final whorl. The test wall is penetrated by numerous irregularly distributed pores which are not clearly visible under the binocular microscope. In axial view, the test is distinctly rounded but slightly lobate in outline. The dorsal surface is slightly convex, and the early chambers are obscured by wall thickening. The dorsal sutures are curved and very slightly depressed, and the closely appressed chambers can be distinguished only with difficulty. The peripheral margin is rounded and consists of a broad imperforate band, which is particularly well developed in the early chambers of the final whorl. No raised keel is present. The final chamber projects above the remainder of the last whorl as seen in lateral view. The ventral sutures are straight and slightly depressed, and the chambers are more distinct and wedge-shaped in ventral than in dorsal view. The umbilicus is small and shallow and may be present only as a slight depression in smaller forms. The aperture is a low umbilical to extraumbilical arch, bordered by a faint rim, at the base of the poorly defined apertural face.

The holotype is illustrated on Plate 5, Figure 7. It was collected from Hole 219, Core 18, Section 2, 55-57 cm. The age of this sample is early Late Eocene (P.15). Maximum diameter of the holotype is $0.12 \mathrm{~mm}$; axial elevation is $0.07 \mathrm{~mm}$.

Remarks: The relationships of $G$. laccadivensis with most other known species are not presently understood. It appears, however, to have evolved from $G$. pseudoscitula by the loss of the distinct, raised keel, rounding of the periphery, and increase in the number, size, and density of the pores. The author's concept of $G$. laccadivensis includes forms with a poorly developed but distinct keel and an acute periphery on the final chamber (Plate 5, Figure 11), although it may prove desirable to refer these to $G$. pseudoscitula. Typical forms, however, were observed at the base of the stratigraphic range recorded here for this taxon.

G. laccadivensis is quite similar to Turborotalita primitiva Brönnimann and Resig, differing primarily in having a greater number of pores, a less pustulose chamber wall, a less embracing final chamber, and more chambers per whorl. The morphology of the latter species, however, is closer to Globanomalina laccadivensis than to Turborotalita spp., and it probably should be referred to Globanomalina. There seem to be no known intermediate species throughout the stratigraphic interval separating the range of these forms, but the very small test size suggests that they may have been overlooked.

The species is named for the Laccadive Island group, which is located near Site 219.

Stratigraphic Range: Middle P.14 to middle P.17 (late Middle to Late Eocene).

Globanomalina pseudomenardii (Bolli)

Globorotalia pseudomenardii Bolli, 1957a, pl. 20, figs. 14-17. Planorotalites pseudomenardii (Bolli), McGowran, 1968, pl. 4, figs. $5-9$. 
Globanomalina pseudomenardii (Bolli), Steineck, 1971b, fig. 4 .

Stratigraphic Range: This species is present, as isolated specimens, in several samples from the shallow-water sediments (Cores 27 through 14A) of P.4 age at Site 219.

\section{Globanomalina pseudoscitula (Glaessner)}

(Plate 6, Figures 1, 2)

Globorotalia pseudoscitula Glaessner, 1937, p. 32, fig. 3.

Globorotalia renzi Bolli, $1957 \mathrm{c}$, pl. 38, fig. 3 .

Remarks: The evolution of $G$. pseudoscitula into $G$. laccadivensis n.sp. in the late Middle Eocene has been discussed above. There seems to be no basis for distinguishing $G$. renzi from this species.

Stratigraphic Range: P.8 to P.14.

\section{Globanomalina pusilla laevigata (Bolli)}

Globorotalia pusilla laevigata Bolli, 1957a, pl. 20, figs. 5-7.

Remarks: See comments for $G$. pusilla pusilla, below.

Stratigraphic Range: Isolated specimens were recovered from Cores 3A, 4A, 6A, and 12A, of P.4 age, at Site 219.

\section{Globanomalina pusilla pusilla (Bolli)}

Globorotalia pusilla pusilla Bolli, 1957a, pl. 20, figs. 8-10.

Remarks: Although it shares the morphological characters of the genus, G. pusilla s.l. is referred to Globanomalina with some reservations because of serious uncertainties as to its phylogeny. Berggren (1968, lineage 1) and McGowran (1968, lineage 1) have placed this species in an evolutionary sequence different from that ascribed to the other species here included in Globanomalina. The lineage in question, however, is unconvincing. It involves the transition from a form with a rounded periphery, no keel, and a coarsely perforate or cancellate wall ("Globigerina" spiralis Bolli), through one with a sharply angular and carinate periphery, and a finely perforate wall (Globanomalina pusilla s.1.), to a descendent (Acarinina convexa) with a subacute, noncarinate periphery and a pseudospinose wall. The author suspects that these lineages are based on little more than test form. The changes in other characters, while possible, are unlikely and this lineage, if it is to be accepted, requires more documentation than is presently available.

Stratigraphic Range: A single specimen was observed in Core 12A, Section 3, Site 219 (P.4 age).

\section{Genus GLOBIGERINA d'Orbigny, 1826}

Type Species: Globigerina bulloides d'Orbigny.

Remarks: The author's concept of this genus is significantly more restricted than that employed in most other published accounts and is based largely on considerations of wall texture and phylogeny. The wall of Globigerina bulloides (Plate 7, Figure 1) is fundamentally a flat surface, penetrated by roughly cylindrical pores with no evidence of pore pits or interpore ridges. These pores appear to have no regular pattern of distribution. Between the pores are short blunt projections, which represent the bases of long, slender spines observed in living specimens. Fossil specimens of Globigerina spp. have a characteristically hispid appearance, and no regular pore pattern is evident (Plate 6, Figures 3,4). This type of wall has been called "spinose," and the concept of Globigerina s.s. as employed here is restricted to species with this surface texture.

The species which the author would refer to Globigerina as so defined are rare in the recovered Arabian Sea sediments, and it has not been possible to examine wall textures or to evaluate phylogeny. Published illustrations and lineages, however, suggest that wall structure is of great phylogenetic importance with respect to this group and serves as a taxonomically valid basis for its distinction.

The ultimate ancestor of Globigerina s.s. is not known with certainty, but the earliest spinose-walled globigeriniform species appears to be $G$. officinalis Subbotina. This form was originally described as possessing a smooth wall, but subsequent illustration (Eames et al., 1962, pl. 9, figs. A, B, C) suggests that it is instead spinose. $G$. officinalis appears to have given rise to three separate but closely related and morphologically similar stocks: (1) $G$. praebulloides s.1.-G. bulloides (P.13 to N.23); (2) the G. ouachitaensis s.l. group (P.15 to N.5); and (3) the G. anguliofficinalis $-G$. angulisuturalis sublineage (P.17 to N.4). All of the species involved in these bioseries have a spinose wall, and the author is unaware of any globigeriniform species in which a spinose wall is prevalent that are not associated with one of these evolutionary patterns. The sole possible exception, $G$, angustiumbilicata, also evolved from $G$. officinalis in the Late Eocene (Blow, 1969). It can thus be seen that $G$. bulloides, the type species, is representative of, and closely related to, a group of species with a common wall type and apertural position, and it is to this association that the concept of Globigerina is herein restricted.

It may prove possible, when the evolutionary patterns of this group in the Eocene are better understood, to recognize subgenera on a lineage basis. This has not proved possible on the basis of the inadequate Arabian Sea material.

In practice, Globigerina, while defined on the basis of phylogenetic considerations, can be recognized by the spinose wall and the basically umbilical position, although one species with an extraumbilical-peripheral aperture and a spinose wall, "Globorotalia" obesa Bolli, should probably be included. The primary effect of restricting the definition of Globigerina in this manner is to exclude from this genus a large number of unrelated species whose apertural position is umbilical. In virtually all cases, these can be recognized on the basis of distinct morphological characters, primarily but not exclusively wall texture. Most of these have been placed in the genera Subbotina, Turborotalia, or "Globigerina," and are discussed in connection with those genera. By the above definition, the only living species of Globigerina are $G$. bulloides, $G$. calida Parker, and $G$. digitata Brady. It may be that $G$, antarctica Keany and Kennett (1972) should be included, but the nature of its wall cannot be clearly ascertained from the holotype illustration.

\section{Globigerina angustiumbilicata Bolli}

Globigerina ciperoensis angustiumbilicata Bolli, 1957b, pl. 22, figs. 12. 13.

Stratigraphic Range: P.18-P.19 to N.10, with very rare isolated occurrences, probably reworked, in the late Neogene at Site 219.

\section{Globigerina bulloides d'Orbigny}

(Plate 6, Figure 3; Plate 7, Figure 1)

Globigerina bulloides d'Orbigny, 1826, Model No. 76.

Globigerina bulloides d'Orbigny, Banner and Blow, 1960b, pl. 1, figs. 1 (lectotype), 4.

Stratigraphic Range: N.17 to N.23.

\section{Globigerina calida Parker} (Plate 6, Figure 4)

Globigerina calida Parker, 1962, pl. 1, figs. 9-13, 15. Remarks: G. calida praecalida Blow was not observed. Stratigraphic Range: Late N.21 to N.23.

\section{Globigerina digitata Brady}

Globigerina digitata Brady, 1879, p. 286.

Globigerina digitata Brady, 1884, pl. 80, figs. 6-10.

Globorotalia (Hastigerinella) digitata (Brady), Banner and Blow, 1959, fig. $4 \mathrm{e}$ (lectotype).

Globorotalia (Beella) digitata (Brady), Banner and Blow, 1960a, fig. 11.

Remarks: Because the test is spinose over the entire wall, it has been preferred here to refer the few specimens to Globigerina and to ascribe to the modifications in coiling, aperture, and chamber extension, species-level importance only. The author is quite convinced, however, on the basis of wall texture considerations, that $G$. digitata is unrelated to either Globorotalia or Turborotalia, as suggested by Banner and Blow (1960a). The possibility is recognized, following Blow (1969), that Beella should be distinguished as a subgenus of Globigerina .

Stratigraphic Range: Rare occurrences of this species were noted in Zone N.22 at Site 219.

\section{Globigerina praebulloides occlusa Blow and Banner}

Globigerina praebulloides occlusa Blow and Banner, in Eames et al., 1962 , pl. 9, figs. U, V, W.

Stratigraphic Range: Very rare, isolated specimens were observed over the range P.18-P.19 to N.21 at Site 219. The late Neogene occurrences in particular may be reworked. 


\section{Globigerina praebulloides praebulloides Blow}

Globigerina praebulloides Blow, 1959 , pl. 8, fig. 47 ; pl. 9, fig. 48 .

Globigerina praebulloides praebulloides Blow, Blow and Banner, in Eames et al., 1962, pl. 9, figs. O, P, Q.

Stratigraphic Range: P.18-P.19 to N.18. Some of the late Neogene specimens are probably reworked.

\section{Genus “GLOBIGERINA," non GLOBIGERINA d'Orbigny}

Remarks: Most of the species included here in "Globigerina" have consistently been referred to Globigerina by previous authors. They are excluded from that genus by the restricted definition invoked above, but more importantly, all of these forms have a number of distinct morphologic characters in common and appear to have evolved throughout the Neogene completely independent of Globigerina s.s.

The primary feature by which "Globigerina" may be distinguished from Globigerina s.s. is the nature of the wall (Plate 7 , Figures 1, 2, 3, 4, 5). The wall structure of Globigerina bulloides (Plate 7, Figure 1) has already been described. The spinose wall contains pores without distinct pore pits and raised spine bases on an otherwise flat surface. The wall in "Globigerina," however, is distinctly cancellate (Plate 7. Figures 2, 3, and 5), the pores are located in well-developed pore pits separated by interpore ridges. Even in "G." rubescens rubescens, known to possess long thin spines when living (Parker, 1962), spine bases are not a distinctive feature (Plate 7, Figure 2). These high-magnification illustrations emphasize the basic point of this discussion: there is a fundamental difference in wall structure between Globigerina and "Globigerina." This distinction may be readily observed at lower magnifications (Plate 6, Figures 3-10). The wall of "Globigerina" appears distinctly cancellate or coarsely perforate in contrast to the hispid appearance of Globigerina bulloides. In practice, there is virtually no difficulty involved in distinguishing the textures.

There are additional morphological characteristics common to most or all of the species considered here. All have a distinct imperforate rim around the aperture. This feature is similar to the lip occasionally observed in specimens of $G$. bulloides or $G$. calida, but in the latter two species the lip does not take the form of a thickened rim. Most species of "Globigerina" also have closely appressed chambers, in contrast to the loosely attached chambers of most typical Globigerina spp. (in particular, $G$. praebulloides s.l. and $G$. bulloides), and most have low apertures of limited lateral extent. The most consistent features, however, are the cancellate wall texture and the apertural rim, which are sufficient to distinguish these genera in virtually all cases.

When the importance of the cancellate wall is recognized and published illustrations are examined with respect to this feature, it becomes obvious that many Neogene globigeriniform species are associated with "Globigerina." The earliest forms to evolve appear to be "Globigerina" woodi woodi (Jenkins) and "G." woodi connecta (Jenkins), which first appeared in the Late Oligocene (Jenkins, 1965a). The immediate ancestor of " $G$." woodi woodi is not known with certainty, but it is not unreasonable to assume that it may have developed from a species with the morphology of, for example, ?"G." labiacrassata (Jenkins), and perhaps ultimately from Turborotalia (or "Globigerina"?) ampliapertura. Because the origins of this group are not clear and because the taxonomic effect of any systematic change in this important group would be relatively great, it does not seem justified to erect a new generic name until the critical relationships are known.

Three moderately well defined groups of "Globigerina" species can be recognized. The first consists of compact heavy-walled forms which appear to have evolved from " $G$." woodi connecta, to which they are similar, in the Early Miocene. These include " $G$." nepenthoides (Brönnimann and Resig) and " $G$." pseudodruryi (Bronnimann and Resig). The heavy cancellate wall and apertural rim may be readily distinguished in the holotype illustrations (Brönnimann and Resig, 1971, pl. 7, figs. 4-9 and 1, 2, respectively; cf. also Plate 6, Figure 10, this report).

The second group consists of smaller and generally thinner walled forms of the lineage " $G$." woodi woodi- "G." druryi- "G." rubescens decoraperta- "G." rubescens rubescens. Additional forms in this group include " $G$." nepenthes, " $G$." apertura, " $G$." sallentina (Dallan, Gianelli, and Salvatorini), "G." falconensis (Blow; cf. Blow,
1969, pl. 16, fig. 1), and "G." tenella. Further discussions of most of the se species are included below.

A third, and smaller, group includes forms which have in common a cancellate wall, a narrow or slit-like aperture with an imperforate rim, and distinct, inflated, loosely appressed chambers. These include " $G$." foliata (cf. Bolli, 1957b, pl. 24, fig. 1; Blow, 1969 , pl. 16, figs. 2, 3; the rim is often indistinct in this form, but is mentioned in the type description), "G." bulbosa (cf. Blow, 1969, pl. 13, figs. 3-6), and "G." parabulloides (cf. Blow, 1969, pl. 18, figs. 1 and particularly 2 ; this species is completely unrelated to $G$. praebulloides or $G$. bulloides). The ancestry of this group is not clear and its evolution has not been observed, but the appearance of " $G$." foliata in sediments of Early Miocene age suggests that it developed from " $G$." woodi woodi.

In summary, "Globigerina" as recognized here consists of a number of species with umbilical apertures, primarily of Neogene age, which have an origin and evolutionary development completely separate from Globigerina s.s. and which may be readily recognized on the basis of their cancellate wall and thickened apertural rim. It appears that when sufficient data become available a new generic name will be necessary for this group.

\section{“Globigerina" apertura (Cushman)}

Globigerina apertura Cushman, 1918, pl. 12, fig. 8. Globigerina bulloides apertura Cushman, Blow, 1969 , pl. 12, fig. 8.

Remarks: The author has examined the holotype of this species at the U.S. National Museum. Cushman's (1918) original illustration is an excellent representation of the specimen. The aperture of the holotype is considerably larger and more irregular than that of the specimen illustrated by Blow, which is probably no more than a slight variant of " $G$," rubescens decoraperta. There is no indication of the subspecies-level relationship with Globigerina bulloides suggested by Blow. The chambers of "G." apertura are more closely appressed than those of $G$. bulloides, and the cancellate wall and apertural rim are evident even on Blow's hypotype. "G." apertura developed from " $G$." rubescens decoraperta by an expansion of the aperture, but these species are otherwise quite similar.

Stratigraphic Range: Very rare specimens were found in Core 219-7 (N.18).

\section{“Globigerina" bulbosa (LeRoy)}

Globigerina bulbosa LeRoy, 1944, pl. 3, figs. 26, 27.

Globigerina bulbosa LéRoy, Blow, 1969, pl. 13, figs. 3-6.

Stratigraphic Range: Rare occurrences were noted in several samples of N.17 age at Site 219.

\section{"Globigerina" nepenthes (Todd) \\ (Plate 6, Figure 7; Plate 7, Figure 5)}

Globigerina nepenthes Todd, 1957, pl. 78, fig. 7 .

Globigerina nepenthes Todd, Blow, 1969, pl. 14, fig. 5 .

Remarks: "G." nepenthes differs from its ancestor, " $G$." druryi (Akers), primarily in its thickened wall, elongate last chamber, and somewhat thinner apertural rim. In spite of the thick wall, the cancellate surface texture can be readily distinguished (Plate 7, Figure 5).

Stratigraphic Range: N.17 at Site 219. Samples representing the remainder of its recorded range in the Middle and early Late Miocene were not recovered.

“Globigerina" pseudodruryi (Brönnimann and Resig) (Plate 6, Figure 10)

Globigerina pseudodruryi Brönnimann and Resig, 1971, pl. 7, figs. 1,2 .

Stratigraphic Range: N.7-N-8, Site 219.

"Globigerina" rubescens decoraperta (Takayanagi and Saito) (Plate 6, Figure 8; Plate 7, Figure 4)

Globigerina druryi decoraperta Takayanagi and Saito, pl. 28, fig. 10 .

Remarks: The author concurs with Blow's (1969) conclusion that this form is only subspecifically different from Globigerina rubescens Hofker and it is so treated here. The differences between these two subspecies include a slightly larger and less oblique aperture, a larger test size, and a more coarsely cancellate wall in " $G$." rubescens decoraperta. 
Stratigraphic Range: N.17 to very near the top of N.21 at Site 219. Samples representing the remainder of the range of this species were not recovered.

\section{"Globigerina" rubescens rubescens (Hofker) (Plate 6, Figure 9; Plate 7, Figure 2)}

Globigerina rubescens Hofker, 1956, pl. 35, figs. 18-21. Globigerina rubescens Hofker, Parker, 1962, pl. 2, figs. 17. 18.

Remarks: The comparison and relationship of the species with " $G$." rubescens decoraperta, from which it evolved in the Middle Pliocene, are discussed above. The cancellate wall, while distinct and evident, is less well developed than in other species of "Globigerina."

Stratigraphic Range: N.19 to N.23.

\section{"Globigerina" tenella (Parker)}

(Plate 6, Figures 5, 6; Plate 7, Figure 3)

\section{Globigerinoides tenellus Parker, 1958, pl. 6, figs. 7-11.}

Remarks: This species has been consistently placed in Globigerinoides because of the presence of a dorsal accessory aperture. It is clear from the morphology and wall structure, however, that the affinities of this form are with species of "Globigerina." It evolved in the latest Pliocene from " $G$." rubescens s.l., and its ancestry is thus independent of Globigerinoides. There is, in fact, no Late Pliocene Globigerinoides sufficiently similar in morphology to " $G$." tenella to be considered ancestral. It should be noted, however, that this latter species is similar to juvenile specimens of Globigerinoides conglobatus illustrated by Parker (1973), but differs in having a much more strongly cancellate wall and less inflated and globular chambers.

The apertural rim is indistinct on the specimen illustrated here, but is generally well developed in Arabian Sea populations.

Stratigraphic Range: Uppermost N.21 to N.23.

\section{Genus GLOBIGERINATELLA Cushman and Stainforth, 1945}

Type Species: Globigerinatella insueta Cushman and Stainforth. Remarks: Blow (1969) has suggested that this genus evolved from Globigerinita ambitacrena. The morphology and wall texture of his illustrated specimens appear to justify this conclusion, particularly with respect to the large and embracing final chamber. The remainder of the test in Arabian Sea specimens, however, is covered with a thick crust, and the nature of the wall is uncertain.

\section{Globigerinatella insueta Cushman and Stainforth}

Globigerinatella insueta Cushman and Stainforth, 1945, pl. 13, figs. 7-9.

Globigerinatella insueta Cushman and Stainforth, Hofker, 1954, fig. 1.

Globigerinatella insueta Cushman and Stainforth, Blow, 1969, pl. 26, figs. 1-7.

Stratigraphic Range: Rare specimens were observed in Core 13, Sections 5, 6, and core catcher, at Site 219 (N.7-N.8 age).

\section{Genus GLOBIGERINATHEKA Brönnimann, 1952}

Type Species: Globigerinatheka barri Brönnimann.

Remarks: The species-level systematics of Globigerinatheka recognized in this paper are based almost entirely on the exhaustive and impressive treatment accorded this genus by Proto Decima and Bolli (1970) and Bolli (1972). Little can be added, on the basis of examination of Arabian Sea specimens, to the discussions concerning species separation and relationships among this particularly complex group. The author fully concurs in the conclusion that there is no morphological basis for distinguishing Globigerapsis. Indeed, the evidence for that conclusion is even more compelling when viewed in terms of the phylogeny of this group.

As emended (Proto Decima and Bolli, 1970), however, Globigerinatheka is restricted to forms with multiple secondary apertures in the final chamber. This somewhat arbitrary distinction is based on purely morphological criteria, and one exception has been made here based on considerations concerning the evolutionary history of this genus.

\section{Globigerinatheka higginsi (Bolli)}

(Plate 8, Figure 4)

"Globigerinoides" higginsi Bolli, 1957c, pl. 36, figs. 11-13.

Remarks: Most authors have followed Bolli in provisionally referring this species to Globigerinoides, despite his recognition of that genus as a Neogene taxon and of the lack of any apparent genetic relationship between Globigerinoides and "G." higginsi. Bolli rejected the conclusion that his species should be referred to Globigerapsis because it differed from G. index in "the possession of a large umbilical aperture, higher spire, and more globular chambers" (Bolli, 1957c, p. 165). While it is admittedly difficult to determine where $G$. higginsi should be placed in any phylogenetic reconstruction of Globigerinatheka (e.g., Bolli, 1972), it is more difficult still to recognize a species from any other Early or early Middle Eocene genus whose morphology suggests a close relationship with this form. Until additional information on the evolutionary history of this form becomes available, it seems appropriate to include it in Globigerinatheka rather than Globigerinoides.

Stratigraphic Range: Rare specimens were observed in sediments of P.10 age in Holes 219 and 220.

Globigerinatheka index index (Finlay)

(Plate 8, Figure 6)

Globigerinoides index Finlay, 1939, pl. 14, figs. 85-88.

Globigerinoides index Finlay, Hornibrook, 1958, pl. 1, figs. 11-13 (holotype reillustrated).

Globigerinatheka index index (Fintay), Bolli, 1972, pl. 1, figs. 1-4, 6,7 .

Stratigraphic Range: Middle P.10 to late P.14. Globigerinatheka index rubriformis (Subbotina)

Globigerinoides rubriformis Subbotina, 1953, pl. 13, fig. 19; pl. 14, figs. 6-9.

Globigerinatheka index rubriformis (Subbotina), Bolli, 1972, pl. 1, figs. 5, 11-13.

Stratigraphic Range: Rare specimens were found in P.11 assemblages at Site 220 .

Globigerinatheka index tropicalis (Blow and Banner) (Plate 8, Figure 7)

Globigerapsis tropicalis Blow and Banner, in Eames et al., 1962, pl. 15 , figs. D, E, F.

Globigerinatheka lindiensis Blow and Banner, in Eames et al., 1962, pl. 15, figs. O, P, Q.

Globigerinatheka index tropicalis (Blow and Banner), Bolli, 1972, pl. 3 , figs. $1-24 ;$ pl. 4 , figs. $7-12$.

Remarks: Bolli (1972) has shown that the presence or absence of bullae in this species is highly variable and should not be accorded taxonomic significance. The illustrated specimen may be seen to have a small accessory bulla.

Stratigraphic Range: P. 14 to P.15.

Globigerinatheka mexicana barri Brönnimann

Globigerinatheka barri Brönnimann, 1952, figs. 3a-c, g, h.

Globigerinatheka mexicana barri Brönnimann, Bolli, 1972, pl. 1, figs. $18-21$; pl. 2 , figs. $8-20$; pl. 4 , figs. 1-6.

Stratigraphic Range: This species was frequently encountered in samples of P.14 age at Site 219; P.12 and P.13 assemblages were not recovered. The species was also observed as isolated specimens in a very few samples from P.10 and P.11, but these occurrences probably represent downhole contamination.

\section{Globigerinatheka mexicana kugleri \\ (Bolli, Loeblich, and Tappan)}

Globigerapsis kugleri Bolli, Loeblich and Tappan, 1957, pl. 6, fig. 6. Globigerinatheka mexicana kugleri (Bolli, Loeblich and Tappan), Bolli, 1972, pl. 2, figs. 6, 7 .

Stratigraphic Range: A single specimen was observed in basal P.11 sediments at Site 220 .

Globigerinatheka mexicana mexicana (Cushman) (Plate 8, Figure 5)

Globigerina mexicana Cushman, 1925, pl. 1, fig. 8 .

Globigerina mexicana Cushman, Blow and Saito, 1968, figs. 1-4 (reillustrated holotype). 
Globigerinatheka mexicana mexicana (Cushman), Bolli, 1972, pl. 2, figs. $1-5$; pl. 4 , figs. 1-6.

Stratigraphic Range: P.11 to top of P.14.

\section{Globigerinatheka semiinvoluta (Keijzer)}

Globigerinoides semi-involutus Keijzer, 1945, pl. 4, fig. 58. Globigerapsis semiinvoluta (Keijzer), Bolli, 1957c, pl. 36, figs. 19 , 20.

Remarks: Bolli (1972) has presented evidence to support the rejection of the contention (Blow and Saito, 1968) that $G$. semiinvoluta and $G$. mexicana s.s. are entirely conspecific. His conclusions are accepted here.

Stratigraphic Range: Latest P.14 to P.15.

\section{Globigerinatheka senni (Beckmann)}

(Plate 8, Figures 10, 11)

Sphaeroidinella senni Beckmann, 1953, pl. 26, figs. 2-4.

Globigerina senni (Beckmann), Bolli, 1957c, pl. 35, figs. 10-12.

Remarks: It appears likely, from the specimens observed in Arabian Sea sediments, that this species is the direct ancestor of Globigerinatheka micra (Shutskaya) proposed by Bolli (1972) as the ancestral species of Globigerinatheka. Although the most distinctive morphotype of $G$. senni contains chambers arranged in a relatively high trochospire, many forms are much more subspherical (cf. Bolli, $1957 \mathrm{c}$, pl. 35, fig. 10). These specimens differ from $G$. micra only in demonstrating a development of umbilical pustules, in having a less slit-like aperture, and in being somewhat less spherical in overall test form. With respect to the last, Shutskaya (1958) noted the variability in test shape in the description of G. micra. The umbilical and apertural differences require only a small evolutionary transition. The G. senni-G. micra sequence is also suggested by the thick crust-like wall of the former, which more closely resembles the thickened surface of $G$. micra and $G$. subconglobata subconglobata than does the wall of any other known late Early Eocene globigeriniform species.

The most subjective aspect of phylogenetic taxonomy is the determination of precisely when a lineage should be recognized as distinct from its ancestral biosequence. In this case, evidence is presented below to indicate the evolution of $G$. senni from Subbotina kiersteadae n. sp., a species which, as typically developed, lacks the encrusted wall of Globigerinatheka spp. G. senni resembles $S$. kiersteadae in lacking accessory apertures, but these features are apparently absent as well in $G$. micra. On the other hand, G. senni is much closer to $G$. micra than to $S$. kiersteadae in possessing a thickened crust-like wall and a very compact test. While no definitive solution to this problem is possible, the closer morphological affinity of $G$. senni to Globigerinatheka than to Subbotina dictates assignment to the former.

Stratigraphic Range: P.9 to P.14. A minor occurrence in the uppermost sample of P.8 age, from the top of a core collected after an extended drilling sequence, probably represents downhole contamination.

\section{Globigerinatheka subconglobata curryi Proto Decima and Bolli} (Plate 8, Figure 8)

Globigerinatheka curryi Proto Decima and Bolli, 1970, pl. 1, figs. $1-4$; pl. 3 , figs. 1,2

Globigerinatheka subconglobata curryi Proto Decima and Bolli, Bolli, 1972, pl. 1, fig. 14.

Stratigraphic Range: Late P.11 at Site 219.

\section{Globigerinatheka subconglobata luterbacheri Bolli}

Globigerinatheka subconglobata luterbacheri Bolli, 1972, pl. 1, figs. $17,22-25$; pl. 7, figs. 1-17.

Stratigraphic Range: A single specimen was observed in Sample 219-19-6, just below a P.11-P.14 unconformity. In view of the published range of this species (P.13-P.15; Bolli, 1972), this specimen should probably be considered as contamination.

\section{Globigerinatheka subconglobata subconglobata (Chalilov)} (Plate 8, Figure 9)

Globigerinoides subconglobatus var. subconglobatus Chalilov (msc.) in Shutskaya, 1958, pl. 1, figs. 4-11.
Globigerinatheka subconglobata subconglobata (Shutskaya), Bolli, 1972 , pl. 1, figs. 8-10, 15, 16 .

Remarks: From the form of the original reference, it is clear that Chalilov should be considered responsible for the conditions that make this name available. According to Article 50 of the International Code of Zoological Nomenclature, the expression of authorship cited above is appropriate.

Stratigraphic Range: Middle P.10 to middle P.11.

\section{Genus GLOBIGERINELLA Cushman, 1927}

Type Species: Globigerina aequilateralis Brady (= junior synonym of Globigerina siphonifera d'Orbigny).

Remarks: Banner and Blow (1959) placed Globigerinella in synonymy with Hastigerina Thomson (type species: $H$. murrayi Thomson $=$ Nonionina pelagica d'Orbigny), a genus in which they included all Neogene species with nearly or completely planispiral adult tests. Bé (1969) recognized the presence of triradiate spines in both Globigerinella siphonifera and Hastigerina pelagica and cited this evidence in support of the proposed synonymy of these genera.

Both interpretations ignore the striking difference in wall structure and spine distribution between these two species. In $H$. pelagica, the development of spines is limited to the broad periphery, and the spines are few, large, and triradiate (Be, 1969, pl. 3 ). Simple spines are absent and the pores are small and lack pore pits. The wall surface is much more complex in G. siphonifera (Bé, 1969 , pl. lb, 2). Both triradiate and simple spines are present and are distributed much more widely over the test surface. The pores are located in weakly depressed pore pits arranged in a regular pattern although the test wall appears typically spinose under light microscopy. These differences in wall texture, and the "distinct cytological difference" recognized by Bé (pl. 4), suggest that the placement of Globigerinella in synonymy with Hastigerina is not justified.

\section{Globigerinella adamsi (Banner and Blow)}

Hastigerina (Bolliella) adamsi Banner and Blow, 1959, fig. 4.

Remarks: G. adamsi differs from $G$. siphonifera in no significant respect other than the radial extension of the chambers of the final whorl. This slight modification in chamber shape does not appear to warrant the erection of a monospecific subgenus.

Stratigraphic Range: Broken but distinctive chambers from specimens of $G$. adamsi were observed in Core 1 , Section 1 and Core 2 , Section 1 at Site 219. The former may represent in situ accumulation of sediments of N.23 age, but the latter probably indicates downhole contamination.

\section{Globigerinella siphonifera involuta (Cushman) (Plate 8, Figure 3 )}

Globigerina aequilateralis involuta Cushman, 1917, fig. 11. Hastigerina (H.) siphonifera involuta (Cushman), Blow, 1969, p. 375. Hastigerina siphonifera involuta (Cushman), Brönnimann and Resig, 1971 , pl. 14 , figs. $4,5$.

Remarks: This inflated and highly involute form can be distinguished from the nominate subspecies and appears to have a different stratigraphic range. It should be noted, however, that considerable in tergradation exists between these two taxa.

Stratigraphic Range: N.17 to middle N.18.

\section{Globigerinella siphonifera siphonifera (d'Orbigny)} (Plate 8, Figures 1, 2)

Globigerina siphonifera d'Orbigny, 1839, pl. 4, figs. 15-18.

Globigerina aequilateralis Brady, 1884, pl. 80, figs. 18-21.

Hastigerina (H.) siphonifera (d'Orbigny), Banner and Blow, 1960a, figs. 2 (lectoty pe), 3.

Globigerinella siphonifera (d'Orbigny), Parker, 1962, pl. 2, figs. 22-28.

Stratigraphic Range: N.17-N.23. Sediments representing the earlier portions of the range of this species were not recovered.

\section{Genus GLOBIGERINITA Brönnimann, 1951}

Type Species: Globigerinita naparimaensis Brönnimann.

Remarks: The justification for distinguishing Catapsydrax and Globigerinita has been presented in detail in connection with the former genus and will only be summarized here. These two genera 
are phylogenetically unrelated and readily distinguishable on the basis of striking differences in the nature of the wall. Catapsydrax, evolving probably from Globorotaloides suteri in the late Middle Eocene, reached its maximum diversity during the mid-Oligocene and became extinct in the Early Miocene. All species properly assigned to Catapsydrax have a cancellate wall in which relatively large pores are located within distinct pore pits. Globigerinita evolved from Tenuitella n. gen. in the Late Oligocene (Jenkins, $1965 \mathrm{~b}$ ) and its modern representatives, particularly G. glutinata s.l., are very widely distributed in the world oceans. All species of Globigerinita have a microperforate wall with extremely small irregularly distributed pores. No pore pits are present, but small pustules or crystallites commonly project above the wall surface. The wall texture distinguishes Globigerinita from all other Neogene genera except Tenuitella spp., from which it may be differentiated by the consistent and characteristic umbilical apertural position. A bulla is commonly but not universally present and frequently is observed with accessory apertures. In all species where the primary aperture has been observed and illustrated, its margin along the final chamber is marked by a fine but distinct lip.

These two genera, therefore, may be easily distinguished on a number of morphological criteria and are unrelated in any meaningful sense. If Tenuitella and Globigerinita are ultimately descended from an Early Paleocene microperforate species, perhaps Globoconusa daubjergensis (Brönnimann), unrelated to the Hedbergella monmouthensis-?Subbotina pseudobulloides series (Berggren, 1962; Olsson, 1970), then the phylogenetic separation of Globigerinita and Catapsydrax predates the base of the Cenozoic.

\section{Globigerinita boweni Brönnimann and Resig (Plate 9, Figure 4)}

Globigerina juvenilis Bolli, Jenkins (non Bolli), 1966, fig. 15, nos. 134-144.

Globigerinita boweni Brönnimann and Resig, 1971, pl. 26, figs. 1-4.

Remarks: It would appear that this form has been commonly referred to Globigerina juvenilis Bolli, which is here considered conspecific with Globigerinita glutinata glutinata. G. boweni differs from Bolli's species in having a much smaller, more compact test, with more closely appressed chambers, a more restricted aperture, and a less lobate periphery. The bulla typically developed in this species, absent in Globigerina juvenilis, was consistently broken in Arabian Sea specimens. Jenkins (1965b) has demonstrated the evolution of this earliest appearing species of Globigerinita from "Globorotalia" munda in the Late Oligocene. One of his specimens (fig. 15, no. 140) is virtually identical with Brönnimann and Resig's holotype.

Stratigraphic Range: N.7-N.8 to N.10 at Site 219. Basal Miocene and uppermost Oligocene sediments were not recovered.

\section{Globigerinita glutinata ambitacrena (Loeblich and Tappan)} (Plate 9, Figure 3)

Tinophodella ambitacrena Loeblich and Tappan, 1957, figs. 2, 3. Globigerinita glutinata (Egger), Parker, 1962, pl. 9, figs. 7-9?, 13-15. Globigerinita glutinata glutinata (Egger), Brönnimann and Resig, 1971 , pl. 23 , fig. 5 .

Remarks: Much has been made of the precise nature of the umbilical bulla in previous attempts to speciate the Neogene Globigerinita complex. The biological and taxonomic significance of this feature, however, is unclear. Examination of large populations of Globigerinita glutinata s.l. from the Arabian and Red seas has convinced the author that there is at present a complete intergradation between forms with highly digitate bullae and numerous accessory apertures (cf. Parker, 1962, p1. 9, figs. 7, 8) and specimens with relatively simple bullae and few infraliminal apertures (Parker, 1962, p1. 9, figs. 13, 14). These forms have typically been assigned to $G$. ambitacrena and $G$. glutinata, respectively (Brönnimann and Resig, 1971). In view of this intergradation, however, no subdivision of the bullate populations appears justified.

Three subspecies of Globigerinita glutinata are recognized here: bullate forms ( $G$. glutinata ambitacrena), nonbullate forms ( $G$. glutinata s.s.), and specimens with accessory dorsal apertures ( $G$. glutinata parkerae). These taxa are clearly very closely related, but evidence from Red Sea populations (Fleisher, Chapter 40, this volume) suggests that they may have somewhat different environmental tolerances. Because the holotype of Globigerina glutinata Egger is nonbullate, specimens possessing an umbilical bulla are assigned to Globigerinita glutinata ambitacrena.

The author has also examined the holotype of $G$. naparimaensis incrusta Akers. This specimen is smaller than typical $G$. glutinata s.l. and has much more distinct and separated chambers. No specimens were observed in Arabian Sea sediments, but $G$. incrusta is probably a separate species. It may prove, however, that $G$. naparimaensis Brönnimann, which was not examined, should be considered a senior synonym of $G$. glutinata ambitacrena.

Stratigraphic Range: N.17 to N.23.

\section{Globigerinita glutinata glutinata (Egger)}

(Plate 9, Figures 1, 2)

Globigerina glutinata Egger, 1893, pl. 13, figs. 19-21.

Globigerina juvenilis Bolli, 1957b, pl. 24, figs. 5, 6 .

Globigerinita glutinata (Egger), Parker, 1962, pl. 9, figs. 1, 4, 10, 12.

Globigerinita glutinata juvenilis (Bolli), Brönnimann and Resig, 1971, fig. 16 .

Remarks: A number of authors have explicitly applied the species-rank name juvenilis to specimens identical to $G$. glutinata (G. glutinata ambitacrena of this report) except for the absence of a bulla (Brönnimann and Resig, 1971, p. 1305; Jenkins and Orr, 1972, p. 1089). The holotype of Globigerina juvenilis has been compared with modern nonbullate specimens of $G$. glutinata s.1. and is virtually identical with them, differing only in showing slightly greater dorso-ventral compression. Because the holotype of Globigerina glutinata Egger is nonbullate, however, G. juvenilis (Bolli) should be considered a junior synonym.

Stratigraphic Range: N.17 to N.23. Older sediments containing relatively undissolved faunas of ages within the reported range of this species were not recovered.

\section{Globigerinita glutinata parkerae (Bermúdez)}

Globigerinoides parkerae Bermúdez, 1961, pl. 10, figs. 10, 11. Globigerinita glutinata (Egger), Parker, 1962, pl. 9, figs. 2, 3, 5, 6, 11.

Globigerinita glutinata flparkerae Brönnimann and Resig, 1971, pl. 23 , figs. $1-4$; pl. 50 , fig. 6 (nom, nov.).

Remarks: Brönnimann and Resig (1971) recognized the close relationship between Globigerinita glutinata s.l. and Globigerinoides parkerae Bermúdez, but concluded that Globigerinita parkerae (Bermúdez) was a junior secondary homonym of G. parkerae Loeblich and Tappan, 1957. They therefore proposed the replacement name Globigerinita glutinata flparkerae for Bermúdez's form. $G$. parkerae Loeblich and Tappan, however, clearly belongs in Turborotalita, a genus Brönnimann and Resig recognized and is probably conspecific with the type species, T. humilis. Therefore, no secondary homonymy exists, and the replacement name should be rejected as a junior synonym (I.C.Z.N., Art. 59 [c] ).

Stratigraphic Range: N.18 to N.23.

\section{Globigerinita uvula (Ehrenberg)}

Pylodexia uvula Ehrenberg, 1861, p. 276; 1873, pl. 2, figs. 24, 25. Globigerina bradyi Wiesner, 1931, p. 133.

Globigerinoides minuta Natland, 1938, pl. 7, figs. 2, 3.

Globigerina bradyi Wiesner, Banner and Blow, 1960b, pl. 3, figs. 1 (lectotype), 2.

Stratigraphic Range: This species occurs as rare specimens over the range $\mathrm{N} .17$ to N.23.

\section{Genus GLOBIGERINOIDES Cushman, 1927}

Type Species: Globigerina rubra d'Orbigny.

Remarks: The origin of this group is not entirely clear. Blow and Banner (in Eames et al., 1962) proposed the evolution of the earliest known species, G. primordius Blow and Banner, from Globigerina praebulloides occlusa at or below (Sieglie, 1973) the Oligocene-Miocene boundary. The respective morphologies of the two species support this possible lineage, but the entailed transition from a fully spinose to a fully cancellate wall, although certainly not impossible, is much less likely. It may be that Jenkins' (1965a) suggestion of a "Globigerina" woodi woodi-Globigerinoides primordius evolutionary sequence deserves more attention than it has received. It also appears that at least one species assigned to this genus evolved separately at a later date. Blow (1970) has discussed 
the evolution of $G$. bollii from "G." woodi woodi in Middle Miocene sediments.

Cordey (1967) has recognized a number of distinct evolutionary sequences within Globigerinoides s.1. While it appears likely that these bioseries have been completely independent since the Early Miocene and thus probably warrant separate status at the subgeneric level, this reclassification has not been undertaken here. It should be noted, however, that the Globigerinoides obliquus-G. ruber and $G$. quadrilobatus s.l. sublineages have been completely separate since the evolution of $G$. obliquus, probably from $G$. altiaperturus, in N.4 (Brönnimann and Resig, 1971). A new subgeneric name for the latter lineage appears to be in order.

Globigerinoides aff. altiaperturus Bolli

(Plate 9, Figures 5, 6)

Globigerinoides triloba altiapertura Bolli (?), 1957b, pl. 25, figs. 7, 8.

Remarks: These specimens differ from Bolli's holotype only in having a smaller dorsal accessory aperture and slightly less dorsoventral compression.

Stratigraphic Range: Lower N.7-N.8 interval, Site 219.

\section{Globigerinoides bollii Blow}

Globigerinoides bollii Blow, 1959, pl. 10, fig. 65 .

Globigerinoides bollii Blow, Blow, 1969, pl. 20, figs. 2, 3 .

Remarks: The apparently independent evolution of this species from "Globigerina" woodi woodi reported by Blow (1970) has already been mentioned. Blow's ideotype illustrations show that these two species are quite comparable in gross test form. It is probable that $G$. bollii, like $G$. tenella Hofker, should be referred to "Globigerina," but the scarcity of $G$. bollii and the absence of " $G$." woodi woodi precluded the verification of this conclusion.

Stratigraphic Range: Rare specimens were observed over the interval N.17 to N.21 at Site 219 .

Globigerinoides conglobatus canimarensis Bermúdez (Plate 9, Figure 8)

Globigerinoides canimarensis Bermúdez, 1961, pl. 10, fig. 5 .

Globigerinoides conglobatus canimarensis Bermudez, Blow, 1969,

pl. 20 , figs. 7,8 ; pl. 21 , fig. 1 .

Remarks: This small subspecies appears to represent an evolutionary and morphologic transition between $G$. obliquus extremus and $G$. conglobatus s.s. Specimens with the flattened final chamber typical of the former were commonly observed.

Stratigraphic Range: N.17 to N.18.

Globigerinoides conglobatus conglobatus (Brady) (Plate 9, Figure 9)

Globigerina conglobata Brady, 1879, p. 286; 1884, pl. 80, figs. 1-5. Globigerina conglobata Brady, Banner and Blow, 1960b, pl. 4, fig. 4 (lectotype).

Globigerinoides conglobatus (Brady), Parker, 1962, pl. 3, figs. 1-5. Stratigraphic Range: N.18 to N.23.

\section{Globigerinoides diminutus Bolli}

Globigerinoides diminutus Bolli, 1957b, pl. 25, fig. 11.

Stratigraphic Range: N.7-N.8 to N.10. Rare reworked specimens were observed in N.17 faunas at Site 219.

\section{Globigerinoides obliquus extremus Bolli and Bermúdez} (Plate 9, Fig. 7)

Globigerinoides obliquus extremus Bolli and Bermúdez, 1965, pl. 1, figs. 10-12.

Remarks: Bolli and Bermúdez (1965) differentiated their new subspecies from $G$. obliquus on the basis of laterally compressed chambers throughout the final whorl, rather than simply in the last one or two chambers. This is a difficult concept to employ, as the compression of the earlier chambers is never so strong as to be distinctive. In fact, it is difficult to see any difference whatever between the holotypes of this and the nominate subspecies. The concept employed here for $G$. obliquus extremus includes specimens in which the final chamber is not only compressed but distinctly flattened. In contrast, most specimens referred to $G$. obliquus obliquus have more inflated and rounded final chambers. The holotype of $G$. obliquus obliquus is considered to be an extreme member of typical populations, in that the final chamber is somewhat compressed but not distinctly flattened. In practice, these concepts result in the recognition of the latter subspecies as composed largely of forms with rounded chambers throughout, which the author feels is the only valid basis for subdivision of this species group.

Stratigraphic Range: N.17 to N.21, N.22?.

\section{Globigerinoides obliquus obliquus Bolli}

Globigerinoides obliqua Bolli, 1957b, pl. 25, figs. 9, 10.

Remarks: See comments above for Globigerinoides obliquus extremus.

Stratigraphic Range: N.7-N.8 to N.21.

Globigerinoides quadrilobatus fistulosus (Schubert)

Globigerina fistulosa Schubert, 1910, fig. 2.

Globigerinoides quadrilobatus hystricosus Belford, 1962, pl. 4, figs. 11-14.

Globigerinoides fistulosus (Schubert), Parker, 1967, pl. 21, figs. 3, 5,6 .

Globigerinoides fistulosus (Schubert), Jenkins and Orr, 1972, pl. 13, figs. 1-9.

Stratigraphic Range: N.19-N.20 to basal N.22 at Site 219. The several meters of overlap with Globorotalia (T.) truncatulinoides suggests that this species ranges into the basal Pleistocene.

Globigerinoides quadrilobatus quadrilobatus (d'Orbigny)

Globigerina quadrilobata d'Orbigny, 1846, pl. 9, figs. 7-10.

Globigerina quadrilobatas d'Orbigny, Banner and Blow, 1960b, pl. 4 , fig. 3 (lectotype).

Globigerinoides quadrilobatus quadrilobatus (d'Orbigny), Blow, 1969 , p. 325.

Remarks: The author fully agrees with Todd (1961) and Bandy (1964c) that the specimen chosen by Banner and Blow as a lectotype is probably not conspecific with d'Orbigny's concept. There seems to be no provision in the International Code of Zoological Nomenclature for the rejection of an improper lectotype other than an appeal to the International Commission. No such appeal seems to have been made; as the name has been widely used, it appears best to retain it.

The subspecies G. quadrilobatus immaturus and G. quadrilobatus trilobus were not separated from the nominate subspecies in the species examination for this report.

Stratigraphic Range: This form was observed in the N.7-N.8 and N.17 to N.23 intervals at Site 219. Older lower Miocene deposits were not recovered.

\section{Globigerinoides quadrilobatus sacculifer (Brady)}

Globigerina sacculifera Brady, 1877 , p. $535 ; 1884$, pl. 80 , figs. 11-17.

Globigerina sacculifera Brady, Banner and Blow, 1960b, pl. 4, figs.

$1,2$.

Remarks: There is some indication (Meyer, 1973) that the distinction between this and the nominate subspecies may be of importance, in that the two forms may have different environmental tolerances.

Stratigraphic Range: N.17 to N.23. This form is generally less common than $G$. quadrilobatus s.s., particularly in the Late Miocene.

\section{Globigerinoides ruber (d'Orbigny)}

Globigerina rubra d'Orbigny, 1839, figs. 12-14

Globigerina elongata d'Orbigny, 1826, p. 277; in Fornasini, 1899, fig. 1; Banner and Blow, 1960b, pl. 3, fig. 10 (lectotype).

Globigerina helicina d'Orbigny, 1826, p. 277; in Fornasini, 1899, fig. 4; Banner and Blow, $1960 \mathrm{~b}$, pl. 2, fig. 5 (lectotype).

Globigerina rubra d'Orbigny, Banner and Blow, 1960 b, pl. 3, fig. 8 (lectotype).

Globigerinoides ruber (d'Orbigny), Parker, 1962, pl. 3, figs. 11-14; pl. 4 , figs. $1-10$.

Stratigraphic Range: At Site 219, G. ruber is consistently common over the interval N.19-N.20 to N.23. It is rare, however, in the uppermost sediments of N.18 age and absent below. This distribution could not be checked at other sites because of heavy test dissolution in late Neogene faunas, but a similar pattern has 
been noted at Leg 24 sites (E. Vincent, personal communication). Blow (1969) and Cordey (1967) have reported that $G$. ruber first evolved in the Late Miocene, and the delay in its appearance in Arabian Sea sediments is probably due to undetermined environmental conditions. It is difficult, however, to imagine what climatic barriers could have been involved inasmuch as $G$. ruber is very widely distributed in tropical waters. The ranges of no other significant species are affected, and there is no indication of intense test solution.

\section{Globigerinoides sicanus s.l. de Stefani} (Plate 9, Figure 10)

Globigerinoides conglobata (Brady), Cushman and Stainforth, 1945 , pl. 13, fig. 6 .

Globigerinoides sicana de Stefani, 1952, p. 9.

Globigerinoides bispherica Todd, 1954, pl. 1, figs. 1, 4.

Globigerinoides quadrilobatus praeimmaturus Brönnimann and Resig, 1971, pl. 9, figs. 1-4.

Globigerinoides pseudosellii Brönnimann and Resig, 1971, pl. 9, figs. 7-9.

Globigerinoides sicanus sicanus de Stefani, Brönnimann and Resig, 1971 , pl. 10, figs. 2,3 .

Globigerinoides sicanus praesicanus Brönnimann and Resig, 1971, pl. 10 , figs. $5,6,8$.

Remarks: The new taxa proposed for this group of subspherical forms by Brönnimann and Resig (1971) may well prove to be valid, but they could not be differentiated consistently in the Early Miocene populations recovered here.

Stratigraphic Range: N.7-N.8 at Site 219.

\section{Globigerinoides subquadratus Brönnimann}

Globigerinoides subquadratus Brönnimann, in Todd et al., 1954, pl. 1 , figs. 5,8 .

Globigerinoides rubra (d'Orbigny), Bolli, 1957b, pl. 25, figs. 12, 13 .

Globigerinoides subquadratus Brönnimann, Cordey, 1967, pl. 103, figs. 14 .

Stratigraphic Range: N.7-N.8 to N.10 at Site 219. It is also present in Core 27 (N.7-N.8) at Site 223 and occurs as reworked specimens in N.17 sediments at Site 219.

\section{Genus GLOBOQUADRINA Finlay, 1947}

Type Species: Globorotalia dehiscens Chapman, Parr, and Collins.

Remarks: In the commonly accepted concept of the genus Globoquadrina, to the degree that it is accepted here, there appear to be four morphologically and phylogenetically distinct lineages, all of which had become independent by the end of the Oligocene. As reconstructed by Blow $(1969$, p. 338-342) but incorporating the taxonomic modifications employed here, these include:

1) Globoquadrina tripartita s.s. $-G$. dehiscens praedehiscens $-G$. dehiscens dehiscens (and including $G$. dehiscens advena). This group is distinguished by the distinctly flattened apertural face which first becomes evident in $G$. dehiscens dehiscens. This sublineage developed near the P.21/P.22 boundary and the final surviving (nominate) subspecies became extinct in the mid-Pliocene.

2) $G$. galavisi-G. altispira globularis-G. altispira globosa-G. altispira altispira. This sequence developed in the later part of P.21, and $G$. altispira altispira became extinct in the Late Pliocene.

3) G. galavisi-G. baroemoenensis-G. larmeui larmeui-G. larmeui obesa. The species in this sublineage, which ranges from P.21 through N.19, consist entirely of small, relatively compact forms with four chambers in the final whorl.

4) $G$. venezuelana $-G$. conglomerata (and including $G$. pseudofoliata). Blow (1969) suggested that this group developed from the " 'G. galavisi-G. altispira globularis' plexus" (p. 323), but $G$, venezuelana could also have evolved from $G$. tripartita s.s. In either case, the evolutionary history and wall texture of these species clearly contraindicate Blow's assignment of this group to Globigerina. All of these forms have inflated chambers and a relatively restricted aperture. This sublineage developed in Zone P.22 and the surviving species, G. conglomerata, is the only true living Globoquadrina.

These four sublineages, taken together, constitute a single broad group of species with strong morphological similarities and with common or nearly common ancestors. All four developed, however, from either G. galavisi or G. tripartita s.s. If one is to consider $G$. dehiscens or $G$. baroemoenensis as morphologically typical of the concept of "Globoquadrina," it is difficult to conceive of a basis, either morphologic or phylogenetic, upon which they can be separated at the generic level from "Globigerina" galavisi Bermudez. The apertural position and umbilical teeth are essentially the same as those in most species of Globoquadrina. G. dehiscens s.s. is an exception, but its immediate ancestor ( $G$. dehiscens praedehiscens) is very similar to $G$. tripartita s.s. The globigeriniform chamber arrangement is in no significant way different from that of the $G$. baroemoenensis or $G$. venezuelana lineage species. The phylogenetic relationship is undoubted. As reconstructed here, all typical Globoquadrina species are descended from either G. galavisi or its immediate descendent, $G$. tripartita s.s. It seems reasonable to include G. galavisi in Globoquadrina.

If this step is taken, the other species descended from G. galavisi must be placed either in Globoquadrina or in a new genus. There is no justification from a phylogenetic viewpoint for the prevalent placement of these species in Globigerina, to which they are completely unrelated. These include $G$. pseudovenezuelana, which evolved from $G$. galavisi in the Middle Eocene, and all members of the late Late Eocene to early Early Miocene bioseries G. galavisi-G. tripartita tripartita-G. tripartita tapuriensis $-G$. sellii-G. binaiensis (Blow, 1969). Of the two options mentioned above, the former has been followed here.

It is probably desirable to separate these five lineages at the subgeneric level. Each is characterized by distinct but minor morphologic features, but they are similar in form and closely related. In the absence of well-developed populations, it has been concluded that such a revision should follow a detailed study of the groups to verify the details of Blow's phylogenetic reconstructions.

Globoquadrina altispira altispira (Cushman and Jarvis) (Plate 10, Figure 1)

Globigerina altispira Cushman and Jarvis, 1936, pl. 1, figs. 13, 14. Globoquadrina altispira altispira (Cushman and Jarvis), Bolli, 1957b, pl. 24 , figs. 7,8 .

Stratigraphic Range: N.7-N.8 to N.19-N.10, ? to basal N.22. This species is common as high as the early part of the N.19-N.20 interval, but rare and somewhat isolated occurrences persist into the basal Pleistocene. It is possible that the latter are reworked.

Globoquadrina baroemoenensis (LeRoy)

Globigerina baroemoenensis LeRoy, 1939, pl. 6, figs. 1, 2.

Globoquadrina baroemoenensis (LeRoy), Blow, 1969, pl. 27, figs. 4 , 8.

Stratigraphic Range: Very rare specimens were recognized over the interval N.7-N.8 to N.19-N.20 at Site 219. The Late Miocene and Pliocene occurrences are probably reworked.

\section{Globoquadrina binaiensis (Koch)}

Globigerina aspera Koch, non Ehrenberg, 1926, figs. 22, 23.

Globigerina binaiensis Koch, 1935 , p. 558 , nom. nov.

Globigerina binaiensis Koch, Blow, 1969, pl. 13, figs. 1, 2.

Stratigraphic Range: P.22 at Site 223 . Very rare, and probably reworked specimens were recorded from a few samples in the N.7-N.8 interval at Site 219.

\section{Globoquadrina conglomerata (Schwager)}

(Plate 10, Figure 2)

Globigerina conglomerata Schwager, 1866, pl. 7, fig. 113.

Globigerina conglomerata Schwager, Banner and Blow, 1960b, pl. 2, fig. 3 (neotype).

Globoquadrina conglomerata (Schwager), Parker, 1962, pl. 6, figs. 11-18.

Remarks: In light of the phylogeny and wall texture of this form, the absence of umbilical teeth in the neotype of $G$. conglomerata does not constitute a valid basis for assigning this species to Globigerina (Blow, 1969). Umbilical teeth are prominent in modern forms clearly conspecific with the neotype (cf. Parker, 1962, pl. 6).

\section{Globoquadrina dehiscens dehiscens} (Chapman, Parr, and Collins)

Globorotalia dehiscens Chapman, Parr, and Collins, 1934, pl. 11, fig. 36. 
Globoquadrina dehiscens (Chapman, Parr, and Collins), Bolli, 1957 b, pl. 24, fig. 3 .

Globoquadrina dehiscens dehiscens (Chapman, Parr, and Collins), Blow, 1969, pl. 28, fig. 1.

Stratigraphic Range: N.7-N.8 to late N.17, with rare and isolated occurrences as high as N.21. These rare occurences at Site 219 may be reworked.

Globoquadrina dehiscens praedehiscens Blow and Banner

Globoquadrina dehiscens praedehiscens Blow and Banner, in Eames et al., 1962, pl. 15, figs. Q, R, S.

Stratigraphic Range: This species occurs in small numbers in samples from the lower N.7-N.8 interval at Site 219.

\section{Globoquadrina galavisi (Bermúdez)}

(Plate 10, Figure 3)

Globigerina galavisi Bermúdez, 1961, pl. 4, fig. 3.

Globigerina yeguaensis yeguaensis Weinzierl and Applin, Blow and Banner, in Eames et al., 1962, pl. 13, figs. H-M.

Globigerina galavisi Bermúdez, Blow, 1969, pl. 5, figs. 1-3 (holotype reillustrated); pl. 16, figs. 4,5 .

Remarks: The origin and early evolutionary history of this species is unknown at present, which precludes a determination of the phyletic point at which Subbotina and Globoquadrina should be distinguished.

The specimen illustrated here possesses a somewhat unusual umbilical bulla, but more typical forms are common.

Stratigraphic Range: P.14 to P.18-P.19.

Globoquadrina larmeui obesa Akers

Globoquadrina obesa Akers, 1955, pl. 65, fig. 5.

Globoquadrina larmeui obesa Akers, Blow, 1969, pl. 28, figs. 7, 9. Stratigraphic Range: Lower part of the N.7-N.8 interval at Site 219. Rare, isolated, and probably reworked specimens were found in N.17 and N.18 at this site as well.

\section{Globoquadrina pseudofoliata Parker}

Globoquadrina pseudofoliata Parker, 1967, pl. 27, figs. 1-3. Stratigraphic Range: N.19-N.20 to lower-middle N.22.

Globoquadrina pseudovenezuelana (Blow and Banner)

Globigerina yeguaensis pseudovenezuelana Blow and Banner, in Eames et al., 1962, pl. 11, figs. J-L, N, O.

Stratigraphic Range: A single occurrence was noted in Sample 219-15, CC (P.18-P.19 age).

\section{Globoquadrina sellii Borsetti}

Globoquadrina sellii Borsetti, 1959, pl. 1, fig. 3.

Globigerina oligocaena Blow and Banner, in Eames et al., 1962, pl. 10 , figs. G, L, M, N.

Globigerina sellii (Borsetti), Blow, 1969, pl. 19, figs. 4-6.

Stratigraphic Range: P.22 at Site 223 only.

Globoquadrina tripartita tapuriensis (Blow and Banner) (Plate 10, Figure 4)

Globigerina tripartita tapuriensis Blow and Banner, in Eames et al., 1962 , pl. 10, figs. H-K.

Stratigraphic Range: Rare specimens were found in a few samples from the P.18-P.19 interval at Site 219. The species is absent at other sites.

\section{Globoquadrina tripartita tripartita (Koch)}

Globigerina bulloides var. tripartita Koch, 1926, fig. 21. Globigerina rohri Bolli, $1957 \mathrm{~b}$, pl. 23, figs. 1-4.

Globigerina tripartita tripartita Koch, Blow and Banner, in Eames et al., 1962, pl. 10, figs. A-F.

Globigerina tripartita Koch, Blow, 1969, pl. 16, fig. 6.

Stratigraphic Range: P.14 to P.22.

\section{Globoquadrina venezuelana (Hedberg)}

Globigerina venezuelana Hedberg, pl. 92, fig. 7.

Globoquadrina venezuelana (Hedberg), Parker, pl. 26, figs. 4-10.

Remarks: Blow (1969) suggested that the similarity between $G$. conglomerata and $G$. venezuelana results from isomorphism rather than phylogenetic affinity, a conclusion he based on unspecified differences in wall structure and texture and on the absence of teeth in the neotype of the former. No differences in the wall were noted here, and as discussed above, teeth are common in modern specimens of $G$. conglomerata. Parker (1967) has discussed the bases upon which these two species may be separated.

Stratigraphic Range: N.7-N.8 to N.19-N.20.

\section{Genus GLOBOROTALIA Cushman, 1927}

Type Species: Pulvinulina menardii var. tumida Brady.

Remarks: With the possible exception of Globigerina, the genus name Globorotalia has probably been applied in recent years to more Cenozoic planktonic species than any other generic level taxon. This has in large part resulted from the widespread use of apertural position as the sole defining character of the genus. Blow (1969), for example, referred virtually every species with an extraumbilical to peripheral aperture to Globorotalia s.l. It is the contention here that, as with Globigerina, the use of apertural position as the only criterion accorded significant importance at the generic level results in a classification scheme that does not reflect the phylogenetic relationships of Cenozoic species.

An examination of the recent literature suggests that three basic approaches to the classification of globorotaliform species have been most consistently applied. Some authors (e.g., Postuma, 1971; Bolli, 1970; Jenkins and Orr, 1972) have applied this generic name to virtually all Cenozoic species with extraumbilical apertures, except for a few, such as Globigerina calida, which obviously belong with other groups. This approach has the advantage of simplicity of application, but does not reflect to any extent whatever the complex and recurrent patterns of evolutionary radiation which have marked Tertiary foraminiferal populations (Cifelli, 1969). Most Paleogene globorotaloid groups are entirely unrelated to Neogene species, a distinction which, in a classification system of the sort described above, must go unrecognized.

Blow (1969) divided these forms into Globorotalia (Globotalia) and $G$. (Turborotalia), a distinction based solely on the nature of the periphery. Forms possessing an imperforate margin, whether or not in the form of a distinct raised keel, are assigned to the former, those lacking such a feature, to the latter. Some authors (e.g., Poag; 1972) have raised these subgenera to full generic status.

This distinction, arbitrary in that it depends fully upon the rigorous application of a single morphological criterion of predetermined significance, cuts directly across the known phylogenetic relationships of many of the species to which it is applied. It is clear from the recognized phyletic patterns that the development of an imperforate margin has no taxonomic significance at the generic level. This feature has appeared independently many times in different lineages. There are at least 11 instances in which, to the extent that phylogenies are known, a carinate species evolved from a noncarinate immediate ancestor. These carinate descendents include: "Globorotalia" pseudomenardii, "G." pseudoscitula, "G." angulata, " $G$." cerroazulensis cunialensis, " $G$." miozea, " $G$." praefohsi, "G." archeomenardii, " $G$." paralenguaensis, "G." margaritae, "G." crassula, and "G." truncatulinoides. In each of these cases, the species is placed in Globorotalia (G.) and its immediate ancestor in $G$. $(T$.$) . It is obvious, therefore, that Blow's generic$ usage has no biological or evolutionary meaning.

Finally, some authors have recognized that the Paleogene groups are distinct from Neogene forms and have separated them in the genera Morozovella, Acarinina (or Truncorotaloides), and Planorotalites (Globanomalina of this report). These modifications are accepted here, as discussed elsewhere, but it is equally celar that there are two large and distinct groups of globorotaloid species in the Neogene that merit separation at the generic level. These are largely referred here to Globorotalia and Turborotalia, but the generic names are not employed in the sense used by Blow (1969).

Globorotalia, as restricted in this report, includes a moderately large number of species grouped in several sublineages which appear to have evolved from a single Early Miocene ancestor. The genus is defined on evolutionary criteria, but in practice all of the included species share a number of morphologic features which distinguish them from species of other genera. All have an extraumbilical aperture, a flap-like apertural lip which differs from the thickened, rope-like apertural rim of Turborotalia spp., and most have a dorsal 
surface on which the chambers are little or not inflated. Most important, these species may be consistently differentiated from other Neogene forms in that they possess a finely perforate wall which contains numerous moderate-sized pores penetrating an otherwise smooth surface with no pore pits and no interpore ridges. This wall type, which appears finely perforate under reflected light, is illustrated below for Globorotalia (Hirsutella) theyeri n.sp. This specimen illustrates another common character-the development of small, subconical pustules around the umbilical region.

The ancestral form of Globorotalia is G. (Fohsella) peripheroronda, which first appeared in early N.4. Olsson (1971, 1972) has suggested that this species developed from Turborotalia (T.) siakensis (Globorotalia mayeri of his report), but the presence of curved dorsal sutures, a slit-like rather than comma-shaped aperture, and the apertural lip (rather than rim) points to Turborotalia (T.) kugleri (Bolli) as a more likely ancestor. The morphologically and phyletically primitive forms of this species $-G$. (T.) peripheroronda forma $\propto$ of Blow $(1969$, pl. 36, fig. 7)-show a wall texture intermediate between cancellate and finely perforate structure. Weakly developed pore pits are present, but the distinct cancellate pattern of $T$. kugleri Blow $(1969$, pl. 38 , figs. 14) is much reduced or absent. Younger and more typical specimens (Olsson, 1972, figs. 5, 6; Plate 10, Figures 7, 8, this report) have a finely perforate wall similar to that of other species assigned to this genus.

This species subsequently gave rise to two distinct lineages with finely perforate walls. The earlier of these, the $G$. $(H$. praescitula-G. scitula sequence, separated from $G$. $(F$. peripheroronda at the base of N.5. This lineage appears to have been ancestral to all but a few of the remaining species of Globorotalia (Blow, 1969, p. 354-356). The exceptions are all included within the $G$. $(F$.) peripheroronda to $G$. $(F$.) fohsi bioseries, which became extinct in the Middle Miocene.

As thus restricted and applied, Globorotalia refers to a monophyletic group of species with readily observed distinguishing morphologic characters. There is no apparent reason why the generic name should be extended to species outside this group.

A number of names are available for the Neogene sublineages of this genus, and Bandy (1972) has recently proposed several others. These are accepted as useful and desirable for taxonomic purposes and are discussed below in connection with species descriptions. Most of these are distinguished purely on a phyletic basis. Only in a few cases may the sublineages be separated by unique morphological criteria.

\section{Subgenus FOHSELLA Bandy, 1972}

Type Species: Globorotalia (Turborotalia) peripheroronda Blow and Banner.

Remarks: The evolutionary development of this bioseries has been discussed in detail by a number of authors (Blow and Banner, 1966; Bolli, 1967; Olsson, 1971, 1972) and is well known. No further discussion appears necessary here. It should be noted that, while this group does not differ from other sublineages in any major morphological aspect, all of the species included are characterized by a smooth but irregular secondary calcite deposit which covers and obscures the dorsal surfaces of the early chambers (cf. Olsson, 1972, figs. 4-11).

Bandy (1972) restricted this subgenus to the sharp- to keelededged members of this lineage. Clearly, $G$. $(F$.) peripheroronda could be assigned to either this or the following subgenus. The morphological affinities of this species, however, are clearly with $G$. $(F$.) peripheroacuta rather than $G$. $(H$.) praescitula, and Bandy's criterion seems unnecessarily restrictive.

Globorotalia (Fohsella) fohsi s.l. Cushman and Ellisor

Globorotalia fohsi Cushman and Ellisor, 1939, pl. 2, fig. 6 . Globorotalia lobata Bermúdez, 1949, pl. 22, figs. 15-17. Globorotalia fohsi robusta Bolli, 1950, pl. 15, fig. 2 .

Remarks: The specimens referred here to $G$. (F.) fohsi s.l. are poorly preserved and represent reworked elements. No at tempt was made to distinguish subspecies or forms.

Stratigraphic Range: Rare reworked specimens were observed in the late Neogene sequence recovered at Site 219.
Globorotalia (Fohsella) peripheroacuta Blow and Banner (Plate 10, Figures 5, 6)

Globorotalia (Turborotalia) peripheroacuta Blow and Banner, 1966, pl. 1 , fig. 2 ; pl. 2 , figs. $4,5,13$.

Stratigraphic Range: N.10 to N.11 at Sites 219 and 223. Rare reworked specimens were recovered from N.17 sediments at Site 219.

\section{Globorotalia (Fohsella) peripheroronda Blow and Banner} (Plate 10, Figures 7, 8)

Globorotalia (Turborotalia) peripheroronda Blow and Banner, 1966, pl. 1, fig. 1; pl. 2, figs. 1-3.

Stratigraphic Range: N.7-N.8 to N.10 at Sites 219 and 223. Rare reworked specimens were occasionally observed in N.17 sediments at the former site.

\section{Globorotalia (Fohsella) praefohsi Blow and Banner}

Globorotalia (Globorotalia) praefohsi Blow and Banner, 1966, pl. 1, figs. 3,$4 ;$ pl. 2 , figs. $1,6,7,10$.

Stratigraphic Range: N.11 at Site 223. Rare reworked specimens were noted in the N.17 assemblages at Site 219 .

\section{Subgenus GLOBOROTALIA Cushman, 1927}

Type Species: Pulvinulina menardii var. tumida Brady.

Remarks: In this subgenus are included most of the "typical" Neogene globorotaliid species, including the type species of Globorotalia s.l. It represents the evolutionary bioseries leading to $G$. $(G$.) cultrata and $G$. $(G$.) tumida.

Bandy (1972), following Blow (1969), recognized two separate sublineages within the group, which he accorded distinct subgeneric status. These include $G$. praescitula-G. archeomenardii-G. praemenardii- $G$. menardii, a lineage for which the name Menardella was erected, and $G$. lenguaensis $-G$. paralenguaensis $-G$. merotumida-G. tumida plesiotumida-G. tumida tumida. It seems clear that $G$. (G.) tumida s.s. and $G$. (G.) cultrata have had slightly different evolutionary histories, and it may be that subgeneric differentiation of the two is warranted. Brönnimann and Resig (1971), however, have noted the presence of $G$. $(G$.) merotumida with N.13 associations older than the evolutionary appearance of $G$. paralenguaensis. The sequence proposed by Bandy thus appears incorrect. Until additional details of the evolution of these forms become available, it does not seem appropriate to recognize Menardella as distinct from Globorotalia.

\section{Globorotalia (Globorotalia) archeomenardii Bolli}

Globorotalia archeomenardii Bolli, 1957b, pl. 28, fig. 11 .

Stratigraphic Range: Very rare specimens were observed in Sample 210-13-2, of late N.7-N.8 age.

\section{Globorotalia (Globorotalia) cultrata (d'Orbigny)}

Rotalia (Rotalie) menardii d'Orbigny, 1826, p. 273 (nomen nudum).

Rotalina (Rotalina) cultrata d'Orbigny, 1839 , pl. 5, figs. 7-9.

Rotalia menardii Parker, Jones, and Brady, 1865, pl. 3, fig. 81 .

Rotalina cultrata d'Orbigny, Banner and Blow, 1960b, pl. 6, fig. 1 (neotype).

Globorotalia (Globorotalia) cultrata cultrata (d'Orbigny), Blow, 1969 , pl. 6 , figs. 4-8.

Globorotalia (Globorotalia) cultrata menardii (Parker, Jones, and Brady), Blow, 1969, pl. 6, figs. 9-11.

Globorotalia (Globorotalia) cultrata exilis Blow, Brönnimann and Resig. 1971, pl. 49, fig. 3.

Globorotalia exilis Blow, Jenkins and Orr, 1972, pl. 23, figs. 1-9. Remarks: It proved impossible to distinguish consistently between the forms referred by Blow (1969) to $G$. (G.) cultrata s.s. and $G$. (G.) cultrata menardii. In fact, if Blow's illustrated specimens are compared, it will be seen that the removal of the last two or three chambers from his $G$. (G.) cultrata s.s. (Blow, 1969, pl. 6, figs. 7,8 ) would produce a test very similar in appearance to $G$. $(G$.) cultrata menardii (Blow, 1969, pl. 6, figs. 9-11). The apparent morphological difference between these forms may be the result of comparing specimens of dissimilar ontogenetic stages.

Blow's concept of $G$. (G.) exilis was restricted to forms with a very thin, delicate wall, and with a complete to near-complete 
absence of limbation along the dorsal intercameral sutures and, in particular, the spiral suture. The name appears to have been commonly applied solely on the basis of the absence of secondary calcite deposits on the dorsal surface. Encrustation per se probably has little or no taxonomic significance. Nonencrusted tests are typical of shallow-water assemblages (Orr, 1967; Fleisher, 1969), and occasional specimens lacking these secondary deposits are typically found in modern deep-water populations. The illustrated forms cited above all have limbate spiral and intercameral sutures and should be referred to $G$. $(G$.) cultrata. $G$. $(G$.$) exilis, as$ restricted to Blow's concept, does not appear to occur in IndoPacific sediments.

Stratigraphic Range: N.17 to N.23 at Site 219. Rare specimens were observed in N.11-N.12 at Site 223.

Globorotalia (Globorotalia) limbata (d'Orbigny) (Plate 11, Figures 1, 2, 3, 4)

Rotalia limbata d'Orbigny, 1826, p. 274 (nomen nudum).

Rotalia limbata d'Orbigny, in Fornasini, 1902, fig. 55.

Rotalia limbata d'Orbigny, Banner and Blow, 1960 b, pl. 5, fig. 3.

Globorotalia (Globorotalia) cultrata limbata (d'Orbigny), Blow, 1969 , pl. 7, figs. 4-6; pl. 42, figs. 2,3 .

Globorotalia multicamerata Cushman and Jarvis, Lamb and Beard, 1972, pl. 14, figs. 5-8.

Remarks: A continuous gradation exists between typical $G$. $(G$.) limbata and $G$. $(G$.) multicamerata, and the distinction between these species is somewhat difficult to recognize in some Neogene assemblages. The concept of $G$. $(G$.) multicamerata has been restricted here to specimens with eight or more chambers in the final whorl, which typically have subrectangular, box-like chambers in the early portion of the last-formed coil. Specimens with seven or seven and one-half chambers in the final whorl (Plate 11, Figures 3, $4)$, here referred to $G$, $(G$.) limbata, are common.

Stratigraphic Range: N.17 to late N.21 at Site 219. Samples representing earlier portions of the published range of $G(G$. limbata were not recovered.

\section{Globorotalia (Globorotalia) merotumida Blow and Banner} (Plate 11, Figures 5, 6)

Globorotalia (Globorotalia) merotumida Blow and Banner, in Banner and Blow, 1965, fig. 1.

Remarks: $G$. (G.) merotumida is very similar to some juvenile forms of $G$. $(G$.) limbata. It differs from the latter in having a very weakly developed to absent umbilicus and in possessing a steep and flattened apertural face separated from the ventral chamber wall by a relatively abrupt change in slope.

Stratigraphic Range: N.17 to the top of N.19-N.20 at Site 219.

Globorotalia (Globorotalia) multicamerata Cushman and Jarvis

Globorotalia menardï var. multicamerata Cushman and Jarvis, 1930 , pl. 34 , fig. 8 .

Globorotalia (Globorotalia) multicamerata Cushman and Jarvis, Blow, 1969, pl. 7, figs. 7-9; pl. 42, fig. 7

Stratigraphic Range: Middle N.18 to basal N.21, Site 219.

\section{Globorotalia (Globorotalia) praemenardit \\ Cushman and Stainforth}

(Plate 12, Figure 2)

Globorotalia praemendardii Cushman and Stainforth, 1945, pl. 13, fig. 14.

Globorotalia praemenardii Cushman and Stainforth, Bolli, 1957b, pl. 29, fig. 4 .

Globorotalia (Globorotalia) praemenardii praemenardii Cushman and Stainforth, Blow, 1969, pl. 6, figs. 1-3 (holotype reillustrated).

Stratigraphic Range: N.10 to N.11-N.12 at Sites 219 and 223. Rare reworked specimens occur in N.17 assemblages at the former site.

\section{Globorotalia (Globorotalia) tumida flexuosa (Koch)}

Pulvinulina tumida var. flexuosa Koch, 1923, figs. 9, 10. Globorotalia tumida flexuosa (Koch), Bolli, 1970, pl, 6, figs. 10-12.
Remarks: Flexuose final chambers have been observed in a number of species of Globorotalia. The modern specimens illustrated by Bé and McIntyre (1970) are more closely related to $G$. $(G$.) cultrata than to $G$. (G.) tumida.

Stratigraphic Range: Early middle N.18 to late N.22.

$$
\begin{gathered}
\text { Globorotalia (Globorotalia) tumida plesiotumida } \\
\text { Blow and Banner } \\
\text { (Plate 11, Figures 7,8) }
\end{gathered}
$$

Globorotalia (Globorotalia) tumida plesiotumida Blow and Banner, in Banner and Blow, 1965, fig. 2.

Remarks: It is commonly difficult to differentiate $G$. (G.) tumida plesiotumida from $G$. (G.) tumida s.s., particularly near the N.17/N.18 boundary where the evolutionary transition occurred. In addition to the criteria suggested by Blow (1969), it is possible to distinguish this subspecies from its descendent by the much smaller umbilicus, much flatter dorsal surface, and smaller and less massive apertural lip.

Stratigraphic Range: N.17 to middle N.18. Globorotalia (Globorotalia) tumida tumida (Brady) (Plate 11, Figures 9, 10)

Pulvinulina menardii var. tumida Brady, 1877 , p. 529.

Pulvinulina tumida Brady, Brady, 1884, pl. 103, figs. 4-6.

Pulvinulina menardii var. tumida Brady, Banner and Blow, 1960b, pl. 5, fig. 1 (lectotype).

Globorotalia (Globorotalia) tumida tumida (Brady), Blow, 1969, pl. 9 , figs. 10-12.

Stratigraphic Range: N.18 to N.23.

Globorotalia (Globorotalia) tumida subsp. 1 (Plate 12, Figure 1)

Remarks: This moderately common form at Site 219 is similar to $G$. $(G$. $)$ tumida flexuosa, but is distinguished by the extreme elongation of the last-formed chambers.

Stratigraphic Range: Late N.18 to middle N.22 at Site 210.

Globorotalia (Globorotalia) ungulata Bermudez

Globorotalia ungulata Bermudez, 1961, pl. 15, fig. 6 .

Stratigraphic Range: Rare specimens occur at Site 219 in isolated samples over the interval of middle N.18 to middle N.22.

\section{Subgenus HIRSUTELLA Bandy, 1972}

Type Species: Rotalina hirsuta d'Orbigny.

Remarks: The concept of this subgenus employed here is essentially the same as that proposed by Bandy (1972), including primarily $G$. (H.) scitula s.1., $G$. (H.) margaritae, and $G$. (H.) theyeri n.sp. G. $(H$.$) praescitula is placed here as well, rather than in G$. (Globorotalia), because of its close morphological similarity with $G$. (H.) scitula s.s.

Blow (1969) has discussed the phyletic history of these forms. Globorotalia (Hirsutella) hirsuta praehirsuta Blow (Plate 12, Figures 5, 6)

Globorotalia (Globorotalia) hirsuta praehirsuta Blow, 1969, pl. 43, figs. 3-7.

Remarks: The ventral inflation of the chambers in the final whorl appears to be the most satisfactory basis for the separation of this species from $G$. $(H$.$) margaritae.$

Stratigraphic Range: Middle to top N.18, Site 219.

\section{Globorotalia (Hirsutella) margaritae \\ Bolli and Bermudez \\ (Plate 12, Figures 3, 4)}

Globorotalia margaritae Bolli and Bermudez, 1965, pl, 1, figs. 16-18.

Remarks: See comments above for $G$. (H.) hirsuta praehirsuta. Stratigraphic Range: Middle to top N.18 at Site 219.

\section{Globorotalia (Hirsutella) scitula gigantea Blow}

Globorotalia scitula gigantea Blow, 1959, pl. 16, fig. 127.

Globorotalia (Turborotalia) scitula gigantea Blow, Blow, 1969, p. 354-356.

Stratigraphic Range: Rare large specimens, tentatively assigned to this taxon, were recovered from several samples of N.17 and early N.18 age at Site 219. 
Globorotalia (Hirsutella) scitula praescitula Blow (Plate 12, Figures 7, 8)

Globorotalia scitula praescitula Blow, 1959, pl. 19, fig. 128.

Globorotalia (Turborotalia) scitula praescitula Blow, Blow, 1969, $\mathrm{pl}$. 4, figs. 21-23 (holotype reillustrated); pl. 39, fig. 9.

Remarks: One of the specimens illustrated here (Plate 12, Figure 7) has a kummerform final chamberlet, which was not typically encountered. The New Zealand form referred to this taxon (Jenkins, 1971) has a distinct comma-shaped aperture similar to the original, but not the subsequent, illustration of the holotype. It does not appear to be the same as Blow's subspecies.

Stratigraphic Range: N.7-N.8 at Site 219 .

Globorotalia (Hirsutella) scitula scitula (Brady)

Pulvinulina scitula Brady, 1882, p. 716-717.

Pulvinulina scitula Brady, Banner and Blow, 1960b, pl. 5, fig. 5 (lectotype).

Globorotalia (Turborotalia) scitula scitula (Brady), Blow, 1969, pl. 39 , fig. 7.

Stratigraphic Range: N.17 to N.23 at Site 219

Globorotalia (Hirsutella) theyeri, new species

(Plate 12, Figure 9; Plate 13, Figures 1, 2, 3, 4, 5)

Globorotalia hirsuta (d'Orbigny), Parker, 1962, pl. 5, figs. 12, 14.

Description: The test is large and planoconvex to unequally biconvex, with up to 16 chambers arranged in a low trochspire. The final whorl consists of 4 to 5 chambers, typically with 4 in smaller tests and $4 \frac{1}{2}$ in larger specimens. In outline, the test is strongly lobate and the chambers flare markedly in the final whorl. This is particularly true of the final few chambers. The test wall is thin, translucent, and finely and uniformly perforate. The peripheral margin is highly acute and is marked by a thin imperforate keel that is difficult to observe in reflected light. In most speciments, this keel is somewhat discontinuous. It is well developed along the posterior peripheral margin of each chamber (Plate 13, Figures 3,5), becomes weaker toward the anterior end of the same chamber, and may disappear altogether. The progression on each chamber is from an imperforate raised carina, to a perforate raised carina, and finally to a perforate and rounded margin (Plate 13, Figure 4). On small specimens (Plate 12, Figure 9) this discontinuous development may occur only on the last chamber. The early whorls are somewhat obscured by secondary calcite deposits. The dorsal surface is slightly convex, but appears relatively flat in contrast to the inflated ventral surface. The chambers are only slightly inflated dorsally. The dorsal intercameral sutures are strongly recurved, and both intercameral and spiral sutures are distinctly depressed, particularly within the final whorl. The ventral side is much more elevated than the dorsal, and the chambers are inflated to a much greater degree. Ventral sutures are radial and straight, but may become slightly recurved near the periphery. The umbilicus is relatively large, open, and deep. Small conical crystallites or pustules are present on the chamber walls and keel in the umbilical region, but are more common on ventral than on dorsal surfaces. The apertural face is steep, but the transition from ventral wall to apertural face is rounded and gradual. The aperture is an open arch at the base of the apertural face and extends from the umbilicus almost to the periphery. It is immediately bordered by a distinct but thin lip and surrounded by a broad imperforate region covering nearly half of the apertural face. Almost all observed specimens are sinistrally coiled.

The holotype is illustrated on Plate 13, Figures 1 and 2. It was collected from Hole 219, Core 1, Section 1, 110-112 cm. The age of this sample is late Quaternary (N.23?). The maximum diameter of the holotype is $0.79 \mathrm{~mm}$; the axial elevation is $0.32 \mathrm{~mm}$.

Remarks: The flared and very loosely appressed chambers of the final whorl and the distinctly flattened dorsal surface distinguish $G$. (H.) theyeri from many other late Neogene species. It differs from $G$. (H.) scitula s.l. in possessing as well a thin peripheral keel, and from $G$. (H.) hirsuta in the much flatter dorsal side. It may be separated from $G$. (H.) hirsuta praehirsuta and $G$. $(H$.$) margaritae by$ its much greater ventral, and lesser dorsal, elevation and by possessing a relatively large ventral umbilicus. From $G$. (Truncorotalia) crassaformis s.1., $G$. $(T$.$) aemiliana, G$. $(T$.$) crotonensis, and similar$ species, $G$. $(H$.$) theyeri may be distinguished by its more flattened$ and less anguloconical shape, and by the much greater flare and distal extension of the chambers in the final whorl.
This form appears to have been recorded on several occasions, but not distinguished taxonomically from other species. Parker has referred the form to $G$. hirsuta $(1962$, pl. 5, figs. 12, 14) and to $G$. sp. B (Parker and Berger, 1971, p. 101) and has recorded it from the surface sediments of the tropical Indian and South Pacific oceans. Vincent (1972) recognized it as $G$. crassula in late Quaternary associations from the Mozambique Channel. It appears that $G$. $(H$.) theyeri may be restricted to tropical Indo-Pacific regions.

This species is named for Dr. Fritz Theyer, formerly of the University of Southern California and presently at the University of Hawaii.

Stratigraphic Range: Middle N.22 to N.23 (late Quaternary).

Subgenus TRUNCOROTALIA Cushman and Bermudez, 1949

Type Species: Rotalina truncatulinoides d'Orbigny.

Remarks: In this taxon is placed the sublineage $G .(T$. crassaformis-G. (T.) tosaensis-G. $(T$.) truncatulinoides and such related forms as $G$. (T.) crassula, $G$. (T.) crotonensis, and $G$. (T.) aemiliana. For the most part, the species included in this subgenus consist of conicotruncate forms.

\section{Globorotalia (Truncorotalia) crassaformis s.l. (Galloway and Wissler)}

Globigerina crassaformis Galloway and Wissler, 1927, pl. 7, fig. 12. Globorotalia crassula Cushman and R. E. Stewart, 1930, pl. 7, fig. 1. Globorotalia (Turborotalia) oceanica Cushman and Bermúdez, 1949, pl. 8, figs. 13-15.

Globorotalia (Turborotalia) crassaformis ronda Blow, 1969, pl. 4, figs. $4-6$; pl. 37, figs. 6-9.

Globorotalia (Globorotalia) crassula viola Blow, 1969, pl. 5, figs. 4-9.

Remarks: The primary bases for separating $G$. (T.) crassaformis s.l. from $G$. (T.) crassula s.l. would appear to be the presence or absence of an imperforate carina and the degree of ventral inflation. It has not proved possible, however, to consistently distinguish these two morphotypes in the sense recognized by Blow (1969). As these forms are consistently rare in Arabian Sea assemblages, they are here combined in $G$. (T.) crassaformis s.1.

Stratigraphic Range: N.19-N.20 to N.23.

Globorotalia (Truncorotalia) tosaensis Takayanagi and Saito

Globorotalia tosaensis Takayanagi and Saito, 1962, pl. 28, figs. 11, 12.

Globorotalia (Turborotalia) tosaensis tosaensis Takayanagi and Saito, Blow, 1969 , pl. 4 , figs. 10-12; pl. 40, figs. 4-7.

Globorotalia (Turborotalia) tosaensis tenuitheca Blow, 1969, pl. 4, figs. 13-16; pl. 40, figs. 1-3.

Stratigraphic Range: N.21 to early N.22.

Globorotalia (Truncorotalia) truncatulinoides (d'Orbigny)

?Rotalina truncatulinoides d'Orbigny, 1839, pl. 2, figs. 25-27.

Globorotalia (Globorotalia) truncatulinoides truncatulinoides (d’Orbigny), Blow, 1969, pl. 5, figs. 10-12 (neotype); pl. 49, fig. 6.

Globorotalia (Globorotalia) truncatulinoides pachytheca Blow, 1969 , pl. 5 , figs. $13-15$; pl. 48 , figs. 1-5.

Remarks: Partially carinate specimens are included in the concept of this species employed here.

\section{Genus GLOBOROTALOIDES Bolli, 1957}

Type Species: Globorotaloides variabilis Bolli

\section{Globorotaloides hexagonus (Natland)}

(Plate 13, Figure 6)

Globigerina hexagona Natland, 1938, pl. 7, fig. 1.

Globorotaloides hexagona hexagona (Natland), Blow, 1969, p. 373-374.

Remarks: Blow (1969) remarked that this species usually has six, but occasionally seven to eight, chambers in the final whorl. It should be noted, however, that Natland's holotype has only five, as do most of the specimens observed in these samples.

Stratigraphic Range: Middle N.17 to N.23. 
Globorotaloides suteri Bolli

(Plate 13, Figure 7)

Globorotaloides suteri Bolli, 1957b, pl. 27, figs. 9-13.

Remarks: This species may be distinguished from similar species referred to Catapsydrax by the very flat dorsal spire, which represents the early ontogenetic globorotaliform stage.

Stratigraphic Range: P.14 to middle N.7-N.8.

\section{Globorotaloides turgida (Finlay)}

(Plate 13, Figure 8)

Globigerina linaperta var. turgida Finlay, 1939, p. 125.

Globorotaloides turgida (Finlay), Jenkins, 1964, pl. 7, figs. 1-10; pl. 8, figs. 1-12, 13 (holotype).

Remarks: G. turgida can be differentiated from $G$. suteri by the more distinct and separated chambers, more inflated bulla, and less coarsely cancellate wall. Jenkins (1964) has demonstrated the presence of an early globorotaloid ontogenetic stage, which suggests assignment to this genus.

Stratigraphic Range: P.8 to middle P.11, Sites 219 and 220.

\section{Globorotaloides variabilis Bolli}

(Plate 13, Figure 9)

Globorotaloides variabilis Bolli, 1957b, pl. 27, figs. 15-20.

Remarks: Blow (1969) has suggested the criteria useful in distinguishing this species from $G$. hexagonus. To these can be added the distinctly less coarsely cancellate wall of $G$. variabilis.

Stratigraphic Range: N.10 to basal N.19-N.20, Site 219.

\section{Genus HANTKENINA Cushman, 1925}

Type Species: Hantkenina alabamensis Cushman.

\section{Subgenus CRIBROHANTKENINA Thalmann, 1942}

Type Species: Hantkenina (Cribrohantkenina) bermudezi Thalmann (= junior synonym of Hantkenina inflata Howe).

Remarks: Blow and Banner (Eames et al., 1962) have illustrated the relationship between Cribrohantkenina and Hantkenina s.s. It has been concluded here that this phylogenetic end member should not be accorded more than subgeneric status.

\section{Hantkenina (Cribrohantkenina) inflata Howe}

Hantkenina inflata Howe, 1928, pl. 14, fig. 2

Hantkenina danvillensis Howe and Wallace, 1934, pl. 5, figs. 14, 17. Hantkenina mccordi Howe and Wallace, 1932, pl. 10, fig. 1.

Hantkenina (Cribrohantkenina) bermudezi Thalmann, 1942, pl. 1, figs. 5, 6 .

Stratigraphic Range: A single broken specimen was found in Sample 219-17-4.

\section{Subgenus HANTKENINA Cushman, 1925}

Type Species: Hantkenina alabamensis Cushman.

\section{Hantkenina alabamensis Cushman}

Hantkenina alabamensis Cushman, 1925, pl. 1, figs. 1-6; pl. 2, fig. 5; pl. 3 , fig. 1.

Stratigraphic Range: Rare occurrences of this species were observed over the interval P.14 to P.18 at Site 219.

\section{Hantkenina mexicana aragonensis Nuttall}

Hantkenina mexicana aragonensis Nuttall, 1930, pl. 24, figs. 1-3.

Hantkenina aragonensis Nuttall, Postuma, 1971, p. 223, column 1.

Stratigraphic Range: Broken specimens, largely in the form of isolated chambers, were noted in isolated samples from P.10 at Sites 219 and 220.

\section{Hantkenina mexicana mexicana Cushman}

Hantkenina mexicana Cushman, 1925, pl. 2, fig. 2.

Hantkenina mexicana Cushman, Postuma, 1971, p. 223, column 2.

Stratigraphic Range: Rare broken specimens were found in Sample 219-20, CC (uppermost P.10).

Genus HASTIGERINELLA Cushman, 1927

Type Species: Hastigerina digitata Rhumbler (= Hastigerinella rhumbleri Galloway)

\section{Hastigerinella rhumbleri Galloway}

Hastigerina digitata Rhumbler, 1911, pl. 37, figs. 9, ?10.

Hastigerinella digitata (Rhumbler), Cushman, 1927, pl. 10, fig. 9. Hastigerinella rhumbleri Galloway, 1933, pl, 30, fig. 9 (nom. nov.). Hastigerinella digitata (Rhumbler), Banner and Blow, 1960a, figs. 5-8.

Remarks: By general modern usage, Galloway's (1933) conclusion that Hastigerina digitata Rhumbler and Globigerina digitata Brady are congeneric is incorrect and his replacement name is unnecessary. Nonetheless, because Hastigerinella rhumbleri was proposed as a replacement name for $H$. digitata (Rhumbler) prior to 1960, it cannot now be rejected (Int. Code Zool. Nomen., 1964, Art. 59, Sect. c).

Stratigraphic Range: Rare specimens were found in Sample 219-3-1 (N.22 age).

\section{Genus MOROZOVELLA McGowran, in Luterbacher, 1964}

Type Species: Pulvinulina velascoensis Cushman, 1925.

Remarks: The justification for the separation from Globorotalia of the Paleogene species included here in Morozovella has been discussed earlier. The concept recognized in this report is essentially the same as those of Berggren (1968, lineage 3; 1971a, fig. 2) and McGowran (1968, lineage 2). This group of species is entirely of early Middle Paleocene to Middle Eocene age, and all possess a pseudospinose surface texture which contrasts strikingly with the finely perforate wall of Neogene forms. The two genera are morphologically distinct, and their phyletic independence dates from the Early Paleogene.

Most of the species referred to Morozovella possess a peripheral carina formed from thickened pseudospines. This feature is absent, however, in some phylogenetically primitive forms and occurs in a few species referred to Acarinina on the basis of gross test shape. There is a very real possibility that this genus as generally construed is polyphyletic, and Luterbacher (1964) has recognized several groups of apparently related morphotypes which probably represent incompletely recognized sublineages. The current understanding of Paleocene evolutionary patterns, however, is insufficient to subdivide this taxon, and for the present it is probably best to consider Morozovella as a form genus within the framework of Early Paleogene populations.

\section{Morozovella acuta (Toulmin)}

Globorotalia wilcoxensis var. acuta Toulmin, 1941, pl. 82, figs. 6-8. Globorotalia acuta Taulmin, Luterbacher, 1964, figs. 101-104.

Stratigraphic Range: $M$. acuta is present but rare in a number of samples from Cores 27 and $3 \mathrm{~A}$ through $12 \mathrm{~A}$ at Site 219 (P.4 age).

\section{Morozovella angulata (White)}

Globigerina angulata White, 1928, pl. 27, fig. 13.

Globorotalia angulata (White), Bolli, 1957a, pl. 17, figs. 10-12. Globorotalia angulata (White), Luterbacher, 1964, figs. 37-39.

Stratigraphic Range: This species occurs sporadically in samples from Cores 3A through 12A at Site 219 (P.4 age).

\section{Morozovella aragonensis aragonensis (Nuttall) (Plate 14, Figure 1)}

Globorotalia aragonensis Nuttall, 1930, pl. 24, figs. 6-8. Globorotalia aragonensis Nuttall, Bolli, 1957a, pl. 18, figs. 7-9.

Globorotalia aragonensis Nuttall, Luterbacher, 1964, figs. 121-126. Stratigraphic Range: P.8 to P.11, Sites 219 and 220.

\section{Morozovella aragonensis caucasica (Glaessner) (Plate 14, Figure 2)}

Globorotalia aragonensis var. caucasica Glaessner, 1937, pl. 1, fig. 6. Globorotalia caucasica Glaessner, Luterbacher, 1964, fig. 97.

Remarks: A complete gradation exists between $M$. aragonensis caucasica and $M$. aragonensis s.s. The specimen illustrated here is less fully developed than the holotype, but is similar to Luterbacher's (1964) specimen and beyond the range of variation of typical $M$. aragonensis aragonensis. 
Morozovella bandyi, new species

(Plate 14, Figures 3, 4, 5, 6, 7, 8)

Globorotalia spinulosa Cushman, van Heerden, 1970, pl. 1, figs. 1,

Description: The lenticular test is small for species of this genus, with the chambers arranged in a low trochospire. Four to five chambers are present in the final whorl; the early chambers are obscured. The chamber walls are penetrated by numerous relatively small pores with weakly developed pore pits, but no reticulate network of interpore ridges is developed. Blunt pseudospines are well developed along the angular periphery, along the distal portions of the dorsal intercameral sutures, on the umbilical shoulders, and over the ventral surfaces of the early chambers in the final whorl. The dorsal side is slightly convex, but consists of two distinct regions: a broad, raised projection formed by the early chambers, and a relatively flat surface created by the dorsal walls of the chambers of the last-formed whorl. Dorsal sutures are curved and slightly depressed where not obscured by pseudospines. The anterior portion of each chamber is imbricate over the posterior margin of the following chamber. Small but distinct accessory apertures are consistently present along the spiral suture at the inner margin of the final one or two chambers. These take the form of small arcuate openings bordered by a distinct imperforate rim (Plate 14, Figure 7). The periphery is weakly to strongly lobate, with lobations more pronounced in larger specimens, and subacute to acute. A distinct peripheral carina is present, formed from coalesced pseudospines. Elevation of the ventral side is relatively low. Ventral sutures are depressed, and the wedge-shaped chambers (in ventral view), although closely appressed, are distinct. The umbilical shoulders appear roughened because of the development of pseudospines. The umbilicus is relatively wide, deep, and distinct. The aperture is a moderately open arch, extraumbilical in position, at the base of the apertural face.

The holotype is illustrated on Plate 14, Figures $3,4,5$, and was collected from Hole 219, Core 19, Section $6,51-53 \mathrm{~cm}$. This sample is of P.11 age (Globigerinatheka subconglobata subconglobata Zone of Bolli, 1971 = Globigerapsis kugleri Zone of Bolli, 1966).

Remarks: van Heerden (1970) considered his specimens, which are identical with $M$. bandyi, to represent forms of $G$. spinulosa Cushman possessing dorsal apertures. The imperforate rim around each secondary aperture, however, suggests that these openings are not accidental features, but instead represent well-defined structural elements of the test. Specimens of $M$. bandyi, furthermore, were compared with Cushman's holotype by Dr. O. L. Bandy. M. bandyi differs from Globorotalia spinulosa not merely in having accessory apertures, which were present in all specimens observed, but in possessing a distinct and open umbilicus. The accessory apertures and dorsal inflation of the early chambers serve to separate this form from other species of Morozovella.

Van Heerden concluded, from his specimens, that accessory apertures in Paleogene forms are of no taxonomic value, and proposed the rejection of Truncorotaloides. In this case, the morphology of $M$. bandyi suggests that, whatever the significance of dorsal apertures may be in the Acarinina-Truncorotaloides species complex, its affinities are entirely with other species of Morozovella and with $M$. spinulosa (Cushman) in particular.

This species is named for the late Dr. Orville L. Bandy, until his recent death Professor of Geological Sciences, University of Southern California.

Stratigraphic Range: Middle P.10 to P.11 at Sites 219 and 220.

\section{Morozovella coronata Blow}

(Plate 15, Figures 1, 2)

Globorotalia spinulosa Cushman, Bolli, 1957c, pl. 38, figs. 6, 7 .

“Globorotalia (Globorotalia) spinulosa (Cushman)", Blow, 1969, pl. 50 , figs. $2-5$.

Globorotalia (Morozovella) spinulosa coronata Blow, M.S. (The Cainozoic Globigerinida, Leiden, E. J. Brill, in press; W. J. Clarke and P. Brönnimann, personal communication). Stratigraphic Range: Middle P.10 to late P.14.
Morozovella lehneri (Cushman and Jarvis)

Globorotalia lehneri Cushman and Jarvis, 1929, pl. 3, fig. 16. Globorotalia lehneri Cushman and Jarvis, Bolli, 1957c, pl. 38, fig. 11 , not figs. $9,10,12,13$

Globorotalia (Globorotalia) lehneri Cushman and Jarvis, Blow, 1969 , pl. 50, fig. 1.

Remarks: The author's concept of this species is restricted to forms with greatly extended chambers, as illustrated by the holotype.

Stratigraphic Range: Very rare specimens were observed in P.11 at Sites 219 and 220 .

\section{Morozovella velascoensis (Cushman)}

Pulvinulina velascoensis Cushman, 1925, pl. 3, fig. 5 . Globorotalia velascoensis (Cushman), Bolli, 1957a, pl. 20, figs. 1-3. Globorotalia velascoensis (Cushman), Luterbacher, 1964, figs. 92-94, 98, 99

Stratigraphic Range: Isolated occurrences of $M$. velascoensis were noted throughout the shallow-water section recovered in Cores 27 to $14 \mathrm{~A}$ at Site 219 (P.4 age).

\section{Morozovella cf. woodi (El-Naggar)}

(Plate 14, Figures 9, 10)

Globorotalia woodi El-Naggar, 1966, pl. 23, fig. 2.

Remarks: The specimens observed at Site 219 differ slightly from the holotype in usually having four to four and one-half chambers, rather than five, in the final whorl, and in showing somewhat greater ventral elevation. These forms, however, would seem to fit within the concept of $G$. woodi as discussed by El-Naggar (1966).

It has been suggested (El-Naggar, 1969) that this species evolved from Globanomalina pseudomenardii in the middle Late Paleocene, which would entail the assignment of $M$. woodi to that genus. The beaded keel and "papillose" surface of the test, however, suggest that it is related to other species of Morozovella.

Stratigraphic Range: This species is restricted to, but relatively common in Core 12A, Section 3 and Core 14A, Section 3 at Site 219 (early P.4 age).

Genus ORBULINA d'Orbigny, 1839

Type Species: Orbulina universa d'Orbigny.

Orbulina suturalis Brönnimann

Orbulina suturalis Brönnimann, fig. 4, no. 20 (holotype).

Orbulina suturalis Brönnimann, Blow, 1956, fig. 2, nos. 5-7.

Stratigraphic Range: N.10 to N.21 at Site 219 .

\section{Orbulina universa d'Orbigny}

Orbulina universa d'Orbigny, 1839 , pl. 1, fig. 1.

Stratigraphic Range: N.17 to N.23. This species is absent due to test dissolution in samples representing -earlier portions of its recorded range.

\section{Genus PRAEORBULINA Olsson, 1964}

Type Species: Globigerinoides glomerosa glomerosa Blow.

Praeorbulina transitoria (Blow)

Globigerinoides transitoria Blow, 1956, fig. 2, nos. 12-15. Porticulasphaera transitoria (Blow), Bolli, 1957b, pl. 27, fig. 3 .

Stratigraphic Range: Very rare specimens were observed in Sample 219-13-3 (N.7-N.8 age).

\section{Genus PSEUDOHASTIGERINA Banner and Blow, 1959}

Type Species: Nonion micrus Cole.

Remarks: Berggren et al. (1967) have discussed the evolution of the early members of this genus from Globanomalina chapmani, as well as the basis for distinguishing these two genera. 


\section{Pseudohastigerina micra (Cole)}

Nonion micrus Cole, 1927, pl. 5, fig. 12.

Hastigerina micra (Cole), Bolli, 1957 c, pl. 35, figs. 1, 2.

Pseudohastigerina micra (Cole), Banner and Blow, 1959, figs. 4g-i. Pseudohastigerina micra (Cole), Berggren et al., 1967, fig. 9.

Stratigraphic Range: P.11?, P.14 to early P.18-P.19 at Site 219.

Pseudohastigerina naguewichiensis barbadoensis Blow

Pseudohastigerina barbadoensis Blow, 1969, pl. 53, figs. 7-9; pl. 54, figs. 1-3.

Stratigraphic Range: Late P.17 to top P.18-P.19, Site 219.

Pseudohastigerina wilcoxensis (Cushman and Ponton)

Nonion wilcoxensis Cushman and Ponton, pl. 8, fig. 11.

Globigerina pseudoiota Hornibrook, 1958, pl. 1, figs. 16-18.

Hastigerina eocenica Berggren, 1960, pl. 10, fig. 2.

Remarks: It is not clear that $P$. sharkriverensis Berggren and Olsson can be consistently differentiated from $P$. wilcoxensis. The former species, however, is apparently limited to temperate regions (Cordey et al., 1970), and was not encountered in Arabian Sea sediments.

Stratigraphic Range: P.8 to P.11 at Sites 219 and 220 .

Genus PULLENIATINA Cushman, 1927

Type Species: Pullenia obliquiloculata Parker and Jones.

Pulleniatina obliquiloculata finalis Banner and Blow

Pulleniatina obliquiloculata finalis Banner and Blow, 1967, pl. 2, figs. 4-10, pl. 3, fig. 5 ; pl. 4, fig. 10 .

Stratigraphic Range: Early N.22 to N.23 at Site 219.

Pulleniatina obliquiloculata obliquiloculata

(Parker and Jones)

Pullenia obliquiloculata Parker and Jones, 1865, pl. 19, fig. 4.

Pulleniatina obliquiloculata (Parker and Jones), Cushman, 1927, pl. 19 , fig. 5 .

Pulleniatina obliquiloculata obliquiloculata (Parker and Jones), Banner and Blow, 1967, pl. 3, fig. 4 (lectotype); pl. 4, fig. 9. Stratigraphic Range: Early N.19-N.20 to N.23 at Site 219.

Pulleniatina obliquiloculata praecursor Banner and Blow

Pulleniatina obliquiloculata praecursor Banner and Blow, 1967, pl. 3 , fig. 3 .

Stratigraphic Range: Late N.18 to late N.21 at Site 219.

Pulleniatina praespectabilis Brönnimann and Resig (Plate 15, Figure 3)

Pulleniatina sp. ex. interc. primalis Banner and Blow-spectabilis Parker, Banner and Blow, 1967, pl. 2, fig. 1.

Pulleniatina spectabilis praespectabilis Brönnimann and Resig, 1971, pl. 19, figs. $4,7$.

Remarks: This species can be distinguished from others of this genus by the distinct trihedral outline in apertural view and from $P$. spectabilis Parker by the rounded rather than acute periphery. $P$. spectabilis was not encountered and does not appear to be present in Indian Ocean sediments (F. L. Parker, personal communication). Stratigraphic Range: Rare specimens were observed in Samples 219-8-6 and 8, CC, uppermost N.17.

\section{Pulleniatina primalis Banner and Blow}

Pulleniatina primalis Banner and Blow, 1967, pl. 1, figs. 3-8; pl. 3, fig. 2.

Stratigraphic Range: Middle N.17 to latest N.18 at Site 219.

Genus SPHAEROIDINELLA Cushman, 1927

Type Species: Sphaeroidina bulloides var. dehiscens Parker and Jones.

Sphaeroidinella dehiscens (Parker and Jones)

Sphaeroidina bulloides var. dehiscens Parker and Jones, 1865, pl. 19 , fig. 5 .

Sphaeroidina bulloides var. dehiscens Parker and Jones, Banner and Blow, 1960b, pl. 7, fig. 3 (lectotype).
Sphaeroidinalla dehiscens dehiscens (Parker and Jones), Blow, 1969, pl. 29 , fig. 9.

Stratigraphic Range: Samples 219-1-1 to 219-6-1 (early N.19-N.20 to N.23).

\section{Sphaeroidinalla dehiscens immatura (Cushman)}

Sphaeroidina dehiscens var. immatura Cushman, 1919, pl. 14, fig. 2. Sphaeroidinella dehiscens forma immatura (Cushman), Blow, 1969, pl. 29 , fig. 9 .

Stratigraphic Range: N.19-N.20 to middle N.22 at Site 219.

Genus SPHAEROIDINELLOPSIS Banner and Blow, 1959

Type Species: Sphaeroidinella dehiscens subdehiscens Blow.

\section{Sphaeroidinellopsis paenedehiscens Blow}

(Plate 15, Figure 6)

Sphaeroidinellopsis subdehiscens paenedehiscens Blow, 1969, pl. 30, figs. $4,5,9$.

Stratigraphic Range: Middle N.17 to late N.18.

Sphaeroidinellopsis seminulina (Schwager)

Globigerina seminulina Schwager, 1866, pl. 7, fig. 112.

Globigerina seminulina Schwager, Banner and Blow, 1960b, pl. 7, fig. 2 (neotype).

Sphaeroidinellopsis seminulina seminulina (Schwager), Blow, 1969, pl. 30 , fig. 7 .

Stratigraphic Range: N.17 to N.18 at Site 219; very rare specimens were recovered in Core 223-27, of N.7-N.8 age.

\section{Sphaeroidinellopsis sphaeroides Lamb}

(Plate 15, Figure 4)

Sphaeroidinellopsis sphaeroides Lamb, 1969, pl. 1, figs. 1-5; pl. 2, figs. 1-3.

Remarks: Lamb (1969) distinguished his species from $S$. subdehiscens on the basis of its more spherical test outline and development of flangelike lips. Most of the specimens observed in Arabian Sea assemblages are more oval than spherical in outline, but the chambers are considerably less distinct than in $S$. subdehiscens. It was also observed that while the latter species frequently develops a flange along the lower apertural margin, $S$. sphaeroides may be differentiated by the consistent development of flanges both above and below the aperture.

Stratigraphic Range: N.18 to early N.21 at Site 219 .

Sphaeroidinellopsis subdehiscens (Blow)

(Plate 15, Figure 5)

Sphaeroidinella dehiscens subdehiscens Blow, 1959, pl. 12, fig. 71. Sphaeroidinellopsis subdehiscens subdehiscens (Blow), 1969, pl. 30, figs. $1-3,6 ;$ pl. $31 ;$ pl. 32 .

Remarks: See comments above for $S$. sphaeroides.

Stratigraphic Range: N.17 to N.18 at Site 219 .

Genus STREPTOCHILUS Brönnimann and Resig, 1971

Type Species: Bolivina tokelauae Boersma.

Remarks: The minute biserial species included in this genus appear to have been largely ignored in recent biostratigraphic studies as being of probable benthic origin, although their association with typical planktonic populations suggests otherwise (Kierstead et al., 1969; Brönnimann and Resig, 1971). The most likely ancestor appears to be Chiloguembelina, from which Streptochilus differs with respect to significant apertural modifications, but the transition between these genera has not yet been observed.

\section{Streptochilus globigerum (Schwager)}

Textilaria globigera Schwager, 1866, pl. 7, fig. 100.

Chiloguembelina globigera (Schwager), Srinivasan and Sharma, 1969 , p. 100.

Streptochilus globigerum (Schwager), Brönnimann and Resig, 1971 , pl. 51, fig. 2 .

Stratigraphic Range: Middle N.17 to middle N.18 at Site 219.

\section{Streptochilus latum Brönnimann and Resig}

Streptochilus latum Brönnimann and Resig, 1971, pl. 51, fig. 3. Stratigraphic Range: Middle N.17 at Site 219. 
Streptochilus tokelauae (Boersma)

Bolivina tokelauae Boersma, in Kierstead et al., 1969, pl. 1, fig. 1. Streptochilus tokelauae (Boersma), Brönnimann and Resig, 1971, pl. 51, fig. 1 .

Stratigraphic Range: N.18?, N.21 to latest N.22.

\section{Genus SUBBOTINA Brotzen and Pozaryska, 1961}

Type Species: Globigerina triloculinoides Plummer.

Remarks: Because Globigerina has been restricted in this report to spinose-walled forms, the bulk of Paleogene globigerinid species not assigned to Acarinina are placed in the genus Subbotina. As so construed, this taxon contains a morphologically distinctive group of species characterized by an umbilical lip, and by a clearly visible cancellate wall surface. In the subbotinid wall, the pores are regularly arranged and located within pore pits, but the "raised rims" cited by Steineck (1971) may be obscured by secondary wall thickening (cf. Plate 16, Figure 6).

This genus gave rise, during the Middle Eocene, to Globigerina officinalis and the subsequent Globigerina sublineages, but there is no indication that the latter genus is polyphyletic. Thus, despite a late Paleogene stratigraphic overlap, Globigerina and Subbotina represent phyletically and morphologically different groups with the same basic test form but with differing geologic ranges.

Evolutionary patterns within Subbotina have not, for the most part, been established, and it seems likely that subgenus-level subdivision will be possible and desirable. McGowran's (1968) proposed Subbotina bioseries (lineage 4) excludes a number of species (the $S$. eocaena group, for instance) which probably represent a branch or branches from his phylogenetic sequence.

Several species that seem to be morphologically indistinguishable from Subbotina s.s. have been placed in Turborotalia solely on the basis of their phyletic histories. Blow and Banner (in Eames et al., 1962) have documented the evolution, from $T$. (T.) centralis and $T$. increbescens, of species with umbilical apertures $(T,[T]$. pseudoampliapertura and the $T$. [T.] ampliapertura-T. [T.] prasaepis-T. [T.] euapertura lineage respectively). Despite the isomorphic similarity to Subbotina spp., the turborotaliid ancestry of these forms precludes their assignment to this genus.

\section{Subbotina angiporoides (Hornibrook)}

(Plate 15, Figure 7)

Globigerina angipora Stache, 1865 , pl. 24, fig. 36 (nomen dubium). Globigerina angipora Stache, Hornibrook, 1961, fig. 3.

Globigerina angiporoides Hornibrook, 1965, figs. 1, 2.

Globigerina (Subbotina) angiporoides angiporoides Hornibrook, Jenkins, 1971 , pl. 20, figs. 588-594.

Globigerina (Subbotina) angiporoides minima Jenkins, 1971, pl. 17, figs. 510-515.

Globigerina angiporoides Hornibrook, Blow, 1969, pl. 12, figs. 3, 4, 5,7 .

Stratigraphic Range: P.15 to late P.18-P.19.

\section{Subbotina boweri (Bolli)}

Globigerina boweri Bolli, 1957c, pl. 36, fig. 1, not fig. 2 .

Remarks: There appear to be three closely related forms, of which $S$, boweri is one, which have been widely confused. $S$. boweri differs from $S$. frontosa (Subbotina) in having less inflated chambers and a lower (in axial dimension) test. The author has compared the holotypes of $S$. boweri and $S$. patagonica; these forms are specifically or subspecifically distinct, and the former may be distinguished by its conspicuously flattened dorsal surface, in contrast to the subinflated dorsal chamber walls of $S$. patagonica.

An evolutionary bioseries has recently been proposed (Toumarkine and Bolli, 1970) for the transition from "Globorotalia cerroazulensis frontosa" (including $G$. boweri Bolli) to " $G$. cerroazulensis cunialensis." If this proves correct, the $S$. patagonica-boweri-frontosa complex should properly be placed in Turborotalia. The proposed phylogeny is discussed in greater detail in connection with this latter genus, but has not been accepted in full at present.

Stratigraphic Range: P.9 to middle P.11 at Site 220.
Subbotina corpulenta (Subbotina)

Globigerina corpulenta Subbotina, 1953, pl. 9, figs. 5, 7; pl. 10, figs. $1-4$

Globigerina "corpulenta" Subbotina, Hagn and Lindenberg, 1969, fig. 6 a.

Remarks: In connection with a revision of Globigerina eocaena Gümbel, it has been suggested (Hagn and Lindenberg, 1969; Lindenberg, 1969) that $S$. corpulenta and $S$. gortanii should be considered as population variants of $S$. eocaena. In a statistical sense, this conclusion may be justified. It is apparent from published records, however, that the morphotypes represented by these species, despite the recognizable intergradation between them, have different stratigraphic ranges, and they have thus been separated here.

Stratigraphic Range: Very rare specimens were recovered in Sample 220-12-2 (P.11 age).

\section{Subbotina eocaena (Gümbel)}

(Plate 15, Figure 8)

Globigerina eocaena Gümbel, 1868, pl. 3, fig. 109.

Globigerina pseudoeocaena var. pseudoeocaena Subbotina, 1953, pl. 4 , fig. 9 ; pl. 5, figs. $1,2,6$.

Globigerina pseudoeocaena var. compacta Subbotina, 1953, pl. 5, figs. 3,4 .

Globigerina (Subbotina) eocaena Gümbel, Hagn and Lindenberg, 1969 , pl. 1, figs. 1-6 (neotype), text-fig. 6 a.

Remarks: See comments above under $S$. corpulenta.

Stratigraphic Range: P.8 to early P.14.

\section{Subbotina eocaenica (Terquem)}

(Plate 15, Figure 9)

Globigerina eocaenica Terquem, 1882, pl. 9, fig. 4 .

Globigerina eocaenica eocaenica Terquem, Subbotina, 1953 (1971), pl. 11, figs. 8-11.

Globigerina eocaenica var. irregularis Subbotina, 1953, pl. 11, figs. 12-14.

Stratigraphic Range: Early P.10 to middle P.14.

\section{Subbotina gortanii (Borsetti)}

Catapsydrax gortanii Borsetti, 1959, pl. 1, fig. 1.

Globigerina turritilina turritilina Blow and Banner, in Eames et al., 1962 , pl. 13, figs. D, E, F, G.

Globigerina "gortanii" (Borsetti), Hagn and Lindenberg, 1969, text-fig. $6 \mathrm{c}$.

Remarks: See comments above under $S$. corpulenta.

Stratigraphic Range: A single specimen of $S$. gortanii was observed in Sample 223-31-2 of P.18 age.

\section{Subbotina kiersteadae, new species}

(Plate 16, Figures 1-9)

Description: The large, compact, globigeriniform test contains at least eight chambers arranged in a low trochospire, with three and one-half to four in the final whorl. The test wall is coarsely perforate, but in some specimens secondary thickening results in a crust-like appearance (Plate 16, Figures 7,8 ). The typically thick wall (Plate 16, Figure 6) results from an accumulation of microcrystallites in interpore areas. Distinct pore pits are sometimes, but not consistently, apparent. The dorsal side is flattened but not planar. Dorsal sutures are straight to slightly curved, depressed, and distinct. The dorsal surfaces of the chambers are slightly inflated. The periphery is rounded and somewhat lobate. In ventral view, the test is subcircular to subquadrate, and the moderately inflated chambers are globular to subglobular. In some specimens, the last few chambers are distinctly compressed. The ventral sutures are deeply incised. The umbilical aperture is typically quadrate and is located within a broad umbilical depression. Wall thickening is commonly present around the margins of the umbilicus.

The holotype was collected from Hole 219, Core 19, Section 6 , $51-53 \mathrm{~cm}$. The age of this sample is Middle Eocene (P.11; Globigerinatheka subconglobata subconglobata Zone of Bolli, 1972 = Globigerapsis kugleri Zone of Bolli, 1966). The holotype specimen is illustrated in Plate 16, Figures 1, 2, 3. Maximum diameter of the holotype is $0.43 \mathrm{~mm}$. 
Remarks: Subbotina kiersteadae differs from $S$, eocaena in possessing a thicker wall, a larger, more quadrate aperture, a typically subquadrate outline, and a flattened dorsal surface. It has more chambers in the final whorl than $S$. finlayi (Brönnimann), and a larger, more open aperture, a more distinct umbilicus, and a flatter dorsal side than $S$. hornibrooki (Brönnimann). S. kiersteadae may be differentiated from $S$. achtschacujmensis (Chalilov) in having a more quadrate test with more closely appressed chambers and a greater dorso-ventral thickness.

Some forms (Plate 16, Figure 4) possess more globular chambers and a less subquadrate outline than the holotype and resemble $S$. eocaena. An additional morphotype (Plate 16, Figures 8, 9), which intergrades with the forms represented by the holotype, includes small compact tests with a more spherical or subspherical shape and a less flattened dorsal surface, as well as a more restricted, somewhat slit-like aperture. This form is most common near the base of the range of $S$. kiersteadae, and probably gave rise to Globigerinatheka senni (Beckmann) by an additional lateral restriction of the aperture and an increase in the height of the trochospire.

This species is named for Professor Caroline Kierstead, formerly Professor of Geology at Smith College, Northampton, Massachusetts.

Stratigraphic Range: Late P.8 to P.11 at Sites 219 and 220.

Subbotina linaperta (Finlay)

Globigerina linaperta Finlay, 1939, pl. 23, figs. 54-57.

Globigerina (Subbotina) linaperta Finlay, Jenkins, 1971, pl. 18, figs. 551-554.

Stratigraphic Range: P.11?, late P.14 to late P.17.

Subbotina patagonica (Todd and Kniker)

(Plate 17, Figures 2, 3)

Globigerina patagonica Todd and Kniker, 1952, pl. 4, fig. 32.

Globigerina ayalai Bermúdez, 1961, pl. 1, fig. 4.

Globigerina frontosa Subbotina, Toumarkine and Bolli, 1970, pl.1, figs. 1 ? 2,3 .

Globigerina boweri Bolli, Postuma, 1971, p. 145.

Remarks: The specimens illustrated here are not as inflated as the holotype, but show the rounded dorsal chamber surfaces and rounded periphery in the early portion of the final whorl, which distinguish $S$. patagonica from $S$, boweri. The orientation of the side view of the holotype of $S$. boweri (Bolli, 1957c, pl. 36, fig. 1c) is slightly oblique, which obscures the dorsal flatness of the test.

Stratigraphic Range: P.8?, P.9 to late P.11 at Sites 219 and 220.

\section{Subbotina winkleri (Bermúdez)}

(Plate 17, Figure 1)

Globigerina winkleri Bermúdez, 1961, pl. 6, fig. 4 .

Globigerina aff. yeguaensis Weinzierl and Applin, Blow and Banner, in Eames et al., 1962, pl. 11, figs. P, Q.

Stratigraphic Range: P.18-P.19 at Site 219.

\section{Genus TENUITELLA, new genus}

Type Species: Globorotalia gemma Jenkins.

Diagnosis: Tenuitella $\mathrm{n}$. gen. is proposed to include a closely related group of small Cenozoic forms which are usually referred to either Globorotalia or Turborotalia, but which are unrelated to species of either genus. The primary diagnostic characteristic common to all species placed in Tenuitella is a microperforate surface wall texture. The wall in these forms consists of a smooth surface penetrated by extremely small perforations, approximately $0.5 \mu$ in diameter. Small pustules or crystallites are commonly present on the wall surface and may obscure the perforations. In some specimens, these pustules may be so common as to completely cover the fundamentally smooth surface, but in other forms the pustules may be rare or absent. The microperforate wall of Tenuitella spp. typically appears smooth and thin, but in specimens with major pustule development it seems slightly roughened. In well-preserved tests, it may appear translucent. All known species have a minute to small test, an umbilical to extraumbilical or peripheral aperture flanked by a narrow lip or rim, and a rounded periphery lacking a distinct carina. Chambers are arranged in a low trochospiral coil, but in some species (e.g., T. gemma) occasional specimens tend to become pseudoplanispiral.
Tenuitella can be differentiated from almost all other Cenozoic globorotaloid genera by the nature of the wall. The microperforate wall texture is quite different from the relatively smooth wall with large but optically indistinct pores of Globorotalia and the cancellate wall of Turborotalia. These species are differentiated from Acarinina spp. and Morozovella spp. by the absence of large, coarse pseudospines. Testacarinata Jenkins is a distinct but short-lived carinate offshoot of Tenuitella. Globigerinita is a primarily Neogene genus that evolved from Tenuitella in the Late Oligocene and is distinguished by the primarily umbilical aperture and the common presence of a bulla.

The purely morphological differences between Tenuitella and Globanomalina are more difficult to define. In general, species of the latter genus have more compressed and less inflated and distinct chambers than those in Tenuitella, and the wall of Globanomalina appears to be more coarsely perforate. The fundamental basis for recognizing Tenuitella, however, is the common and independent phyletic history of the species included in it, a separate phylogeny of which the distinctive wall texture is the primary reflection. The forms included in Globanomalina and Tenuitella have been evolutionarily separate since at least the early Middle Eocene and probably since the basal Tertiary.

In addition to the species discussed below ( $T$. gemma, $T$. anfracta, $T$. clemenciae), a number of other species should apparently be included in this genus on the basis of published descriptions. These are:

T. aculeata (Jenkins) $=$ Globorotalia inconspicua aculeata Jenkins

T. cifellii (Brönnimann and Resig) $=$ Globorotalia (Turborotalia) cifellii Brönnimann and Resig, partim. (1971, pl. 42, figs. 1-5)

$T$. insolita (Jenkins) $=$ Globorotalia insolita Jenkins

T. minutissima $($ Bolli $)=$ Globorotalia minutissima Bolli

$T$. munda $($ Jenkins $)=$ Globorotalia munda Jenkins

T. nkbrowni (Brönnimann and Resig) = Globorotalia (Turborotalia) nkbrowni Brönnimann and Resig

$T$. parkerae (Brönnimann and Resig) = Globorotalia (Turborotalia) parkerae Brönnimann and Resig, partim. (1971, pl. 43 , fig. 7 , not fig. $10 ;$ pl. 48 , figs. 2,3 )

$T$. praestainforthi $($ Blow $)=$ Globigerinita stainforthi praestain forthi Blow. The last species differs from $T$. gemma only in having an umbilical bulla.

Tenuitella anfracta (Parker)

(Plate 17, Figures 9, 10)

Globorotalia anfracta Parker, 1967, pl. 28, figs. 3-8.

Globorotalia (Turborotalia) anfracta Parker, Brönnimann and Resig, 1971, pl. 43, figs. 2, 3, 6 .

Remarks: The specimens illustrated by Jenkins and Orr (1972, pl. 20, figs, $4,5,6$ ) have a coarsely cancellate wall and should be referred to Globorotaloides $\mathrm{cf}$. hexagoneous

Stratigraphic Range: N.18?, N.19-N.20 to N.23.

\section{Tenuitella clemenciae (Bermúdez)}

(Plate 17, Figure 8)

Turborotalia clemenciae Bermúdez, 1961, pl. 17, fig. 10.

Globorotalia (Turborotalia) clemenciae Bermúdez, Blow, 1969, pl. 35 , fig. 8 .

Remarks: There is a very close similarity between this species and T. munda (Jenkins). The more distinctly separated and subglobular chambers of the specimens observed in Arabian Sea sediments suggest that they should be assigned to $T$. clemenciae.

Stratigraphic Range: N.7-N.8 to N.10 at Site 219 .

\section{Tenuitella gemma (Jenkins)}

(Plate 17, Figures 4, 6, 7)

Globorotalia gemma Jenkins, 1966, fig. 11, nos. 97-103.

Globorotalia (Turborotalia) gemma Jenkins, Blow, 1969, pl. 34, fig. 9.

Globorotalia gemma Jenkins, Jenkins and Orr, 1972, pl. 22, figs. 7-11.

Remarks: The writer's concept of $T$. gemma is best expressed by the hypotypes illustrated by Jenkins and Orr (1972, pl. 22, Figs. 7, 8). The tests observed in Arabian Sea sediments and referred to this species differ from the above-mentioned forms primarily in having a 
slightly less open umbilicus and a more coarsely pustulose wall. The former feature, however, is in good agreement with the holotype, and the latter may result from partial recrystallization of the test wall (cf. Plate 17, Figure 4). The remaining hypotypes illustrated by Jenkins and Orr, however, show that there may be considerable variation within this species in the degree to which pustules are developed.

The Arabian Sea specimens are somewhat similar to forms referred by Jenkins and Orr (1972, pl. 27, fig. 8) to Globorotalia cf. minutissima Bolli, but the aperture is much more open than in Bolli's species.

Stratigraphic Range: P.18-P.19 at Site 219.

Tenuitella sp. 1

(Plate 17, Figure 5)

Globorotalia sp. 4, Jenkins and Orr, 1972, pl. 18, figs. 7-12.

Remarks: Apertural modifications are apparently common and varied in different species of Tenuitella. Most species have a distinct lip, and $T$. praestainforthi has a bulla. This form, which is considerably larger than, but otherwise similar to, $T$. gemma and $T$. praestainforthi, seems to possess a persistent apertural-umbilical flap.

Stratigraphic Range: Rare specimens were recorded in Sample 219-13-1, of N.10 age.

Genus TRUNCOROTALOIDES Brönnimann and Bermúdez, 1953

Type Species: Truncorotaloides rohri Brönnimann and Bermúdez, (= junior synonym of Globigerinoides pseudodubia Bandy)

Remarks: Truncorotaloides is used here for noncarinate species with typical acarininid wall and test morphology in which secondary dorsal sutural apertures are a persistent structural element. Keeled forms with accessory apertures, such as Morozovella bandyi, are excluded.

McGowran (1968) has indicated the sporadic presence of dorsal apertures in a number of acarininid forms and recommended the distinction of Acarinina and Truncorotaloides only at the subgenus level. His lineages also suggest that Truncorotaloides, as recognized in this report, is probably polyphyletic. These interpretations may well prove correct, but the present state of knowledge of Paleogene lineages among these forms is not, it is felt here, sufficiently precise to warrant the suggested reclassification at this time.

\section{Truncorotaloides collacteus (Finlay)}

(Plate 18, Figures 3, 4)

Globorotalia collactea Finlay, 1939, pl. 29, figs. 164, 165.

Truncorotaloides collactea (Finlay), Jenkins, $1965 \mathrm{c}$, figs. 1-27.

Stratigraphic Range: Early P.10 to P.14 at Sites 219 and 220. Very small and rare tests, which should perhaps be assigned to this species, were noted in P.17 at Site 219. These may represent the same form that Berggren (1971a) observed as high as the latest Eocene.

\section{Truncorotaloides pseudodubius (Bandy)}

(Plate 18, Figures 1, 2)

Globigerinoides pseudodubia Bandy, 1949, pl. 24, fig. 1.

Truncorotaloides rohri Brönnimann and Bermúdez, 1953, pl. 87, figs. 7-9.

Truncorotaloides rohri var. guaracaraensis Brönnimann and Bermúdez, 1953, pl. 87, figs. 1, 2, 3 .

Truncorotaloides rohri var. mayoensis Brönnimann and Bermúdez, 1953, pl. 87, figs. 10-12.

Truncorotaloides rohri var. piparoensis Brönnimann and Bermúdez, pl. 87, figs. 4-6.

Stratigraphic Range: Middle P.10 to P.14, Sites 219 and 220.

Genus TURBOROTALIA Cushman and Bermúdez, 1949

Type Species: Globorotalia centralis Cushman and Bermúdez (= junior synonym of Globigerina cerroazulensis Cole).

Remarks: Cushman and Bermúdez (1949) differentiated their subgeneric taxon from Globorotalia s.s. by the presence of a rounded periphery. Loeblich and Tappan (1964) and Blow (1969) subsequently modified this criterion by making the absence of an imperforate carina the critical defining condition. Most other authors who have recognized Turborotalia at either the generic or the subgeneric level have accepted this interpretation.

The point has been made, in the discussion of Globorotalia, that this distinction is phyletically meaningless and that generic or subgeneric boundaries so drawn cut squarely across several recognized lineages. Blow (1969) recognized that peripheral keels developed independently in a number of different Neogene evolutionary sequences. A classificatory basis which does not reflect this circumstance should not be used.

The phyletic concept of Turborotalia employed here includes a long-ranging group of species remarkably consistent in critical morphological features. All of these species are characterized by a cancellate wall texture. All but a very few have an umbilical to extraumbilical or peripheral aperture bordered by a lip or rim. The exceptions to these latter two criteria can be demonstrated to have descended directly from turborotaliid ancestors.

As defined in this manner, Turborotalia can be differentiated from other globorotaliform groups purely on the basis of wall texture. The cancellate wall contrasts with the finely perforate wall of Globorotalia, the microperforate wall of Tenuitella, and the pseudospinose wall of Acarinina and Morozovella. All but one known species lack an imperforate keel, and all but five have a typical globorotaloid apertural position.

Turborotalia appears to be virtually monophyletic (which suggests that wall texture is an excellent basis for the recognition of this group) and probably ranges throughout the Tertiary. A good case can be constructed for including the basal Paleocene form "Globigerina pseudobulloides" in this genus, as most authors have all but recognized by including it in Globorotalia sensu Blow. Early and middle Paleogene phyletic patterns are not well known, but McGowran's (1968) lineage 5 is probably a good approximation. Most of the Neogene species are related to the $T$. opima nana-T. siakensis-T. continuosa-T. acostaensis-T. humerosa lineage suggested by Blow (1969). It can be seen, from this discussion, that the forms here referred to Turborotalia represent a phyletically continuous group with a constant and defining morphological character. As Globorotalia evolved from this lineage only once and as the morphology and subsequent evolution of this genus are different and distinct from Turborotalia, there is no need to recognize a subgeneric relationship between these two taxa.

The lineage recently proposed by Toumarkine and Bolli (1970) poses a significant nomenclatorial problem, principally because their bioseries contains the type species of Turborotalia. If $T$. cerroazulensis s.s. evolved from a subbotinid ancestor independently from the main turborotaloid sequence, as suggested by these authors, then the similarity between $T$. cerroazulensis and, for example, $T$. increbescens (Bandy), is isomorphic rather than phyletic. Under these circumstances Turborotalia could be properly applied only to the $T$. cerroazulensis bioseries and a new generic name, probably Neogloboquadrina, would be required for the other turborotaloid species.

For the present, however, this lineage and its taxonomic implications are not accepted here as conclusively demonstrated. The critical step in the transition from globigeriniform to globorotaliform test shape is represented by Globorotalia cerroazulensis possagnoensis Toumarkine and Bolli. Unfortunately, the holotype and paratypes are not sufficiently well preserved and illustrated to permit an evaluation of the morphology of this species and its relation to the proposed evolutionary sequence.

A few sublineages have terminated in the evolution of forms with umbilical apertures. As discussed by Blow and Banner (in Eames et al., 1962) and Blow (1969), T. pseudoampliapertura is directly descended from $T$. centralis $(=T$. cerroazulensis pomeroli of this report), and $T$. increbescens gave rise to the $T$. ampliapertura- $T$. prasaepis- $T$, euapertura sequence. Although these species are virtually identical in generic-level characters with species of Subbotina, their phylogeny is the basis for the generic assignment made here. Finally, Parker (1967) has documented the evolution of $T$. dutertrei from $T$. humerosa during the Pliocene. The former species, which possesses an umbilical aperture and apertural-umbilical teeth, is a virtual isomorph of Globoquadrina and is placed in a separate subgenus. 
Subgenus NEOGLOBOQUADRINA Bandy,

Frerichs, and Vincent, 1967

Type Species: Globigerina dutertrei d'Orbigny.

Turborotalia (Neogloboquadrina) dutertrei (d'Orbigny)

(Plate 18, Figure 5)

Globigerina dutertrei d'Orbigny, 1839, pl. 4, figs. 19-21.

Globigerina eggeri Rhumbler, in Brandt, 1901, fig. 20.

Globigerina dutertrei d'Orbigny, Banner and Blow, $1960 \mathrm{~b}, \mathrm{pl} .2$, fig. 1 (lectotype).

Globigerina eggeri Rhumbler, Banner and Blow, 1960b, pl. 2, fig. 4 (lectotype).

Neogloboquadrina dutertrei dutertrei (d'Orbigny), Bandy, Frerichs, and Vincent, 1967, pl. 14, figs. 6-12.

Stratigraphic Range: N.19-N.20 to N.23, Site 219.

Subgenus TURBOROTALIA Cushman and Bermúdez, 1949

Type Species: Globorotalia centralis Cushman and Bermúdez (= junior synonym of Globigerina cerroazulensis Cole)

\section{Turborotalia (Turborotalia) acostaensis acostaensis (Blow) \\ (Plate 18, Figure 7)}

Globorotalia acostaensis Blow, 1959, pl. 17, figs. 106, 107.

Globorotalia (Turborotalia) acostaensis acostaensis Blow, Blow, 1969, pl. 9, figs. 13-15 (holotype reillustrated); pl. 33, figs. 1, 2. Stratigraphic Range: N.17 to top of N.21, Site 219.

Turborotalia (Turborotalia) acostaensis tegillata (Brönnimann and Resig) (Plate 18, Figure 8)

Globorotalia (Turborotalia) acostaensis tegillata Brönnimann and Resig, 1971, pl. 33, figs. 3, 6, 7, 10.

Remarks: The treatment of this form as a subspecies of $T$. (T.) acostaensis s.l. is maintained here, but some of the specimens so identified may be related instead to $T$. $(T$.) humerosa.

Stratigraphic Range: N.17 to early N.18 at Site 219.

Turborotalia (Turborotalia) ampliapertura (Bolli) (Plate 18, Figure 6)

Globigerina ampliapertura Bolli, 1957b, pl. 22, figs. 5-7. Stratigraphic Range: P.17 to P.18-P.19.

Turborotalia (Turborotalia) birnageae (Blow) (Plate 18, Figure 9)

Globorotalia birnageae Blow, 1959, pl. 17, fig. 108.

Globorotalia (Turborotalia) birnageae Blow, Blow, 1969, pl. 34, figs. 7, 8 .

Remarks: Blow (1959) described his species as finely perforate, but the holotype, examined by the author, has a typically cancellate wall essentially identical with that of the specimen illustrated here.

Stratigraphic Range: The species occurs over the entire N.7-N.8 interval at Site 219.

\section{Turborotalia (Turborotalia)} bolivariana (Petters)

Globigerina wilsoni var. bolivariana Petters, 1954, pl. 8, fig. 9.

Globorotalia bolivariana (Petters), Bolli, 1957c, pl. 37, figs. 14-16.

Remarks: This species has been considered (Berggren, 1968) to be conspecific with Globigerina wilsoni Cole, but this synonymy cannot be determined from Cole's illustration.

Stratigraphic Range: A single specimen was found in Sample 220-12, CC, early P.11.

\section{Turborotalia (Turborotalia) cerroazulensis cerroazulensis (Cole)} (Plate 19, Figure 1)

Globigerina cerroazulensis Cole, 1928, pl. 32, figs. 11-13.

Globorotalia centralis Cushman and Bermúdez, 1937, pl. 2, figs. 62-65.

Globorotalia cerroazulensis cerroazulensis (Cole), Toumarkine and Bolli, 1970, pl. 1, figs. 19-24.

Remarks: Toumarkine and Bolli (1970) have indicated that the holotype of $G$. centralis is lost and concluded that the paratypes of this species are clearly conspecific with $G$. cerroazulensis Cole. The author would agree with this unfortunate conclusion, which indicates that these two species must be considered synonymous. The concept of $G$. centralis of most authors has been incorporated in Globorotalia cerroazulensis pomeroli Toumarkine and Bolli.

Stratigraphic Range: P.14 to P.15 at Site 219 .

\section{Turborotalia (Turborotalia) cerroazulensis cocoaensis (Cushman)}

Globorotalia cocoaensis Cushman, 1928, pl. 10, fig. 3.

Globorotalia (Turborotalia) cerroazulensis (Cole), Blow, 1969, pl. 36 , figs. 3,4 .

Globorotalia cerroazulensis cocoaensis Cushman, Toumarkine and Bolli, 1970, pl. 1, figs. 28-33.

Stratigraphic Range: Very rare specimens were found over the range of middle P.14 to late P.17 at Site 219; very rare specimens in early P.18-P.19 appear to be reworked.

\section{Turborotalia (Turborotalia) cerroazulensis} cunialensis (Toumarkine and Bolli)

Globorotalia cerroazulensis cunialensis Toumarkine and Bolli, 1970, pl. 1, figs. 37-39.

Remarks: This appears to be the only form included within Turborotalia to develop a keel.

Stratigraphic Range: This species was found, in small numbers, only in Sample 219-16-4, of early P.18-P.19 age, and appears, from the associations in which it is included, to be reworked in this sample.

\section{Turborotalia (Turborotalia) cerroazulensis pomeroli (Toumarkine and Bolli)}

(Plate 19, Figures 2, 3)

Globorotalia cerroazulensis pomeroli Toumarkine and Bolli, 1970, pl. 1, figs. 10-18.

Remarks: See comments above under $T$. (T.) cerroazulensis cerroazulensis.

Stratigraphic Range: Early P.10 to P.17, Sites 219 and 220.

Turborotalia (Turborotalia) continuosa (Blow)

(Plate 18, Figure 10)

Globorotalia continuosa Blow, 1959, pl. 19, fig. 125.

Globorotalia (Turborotalia) continuosa Blow, Blow, 1969, pl. 3, figs. 4-6 (holotype reillustrated).

Stratigraphic Range: $T$. (T.) continuosa was found as rare specimens in N.7-N.8 and early N.17 samples at Site 219, and throughout the N.11-N.12 interval at Site 223.

\section{Turborotalia (Turborotalia) euapertura (Jenkins)}

Globigerina euapertura Jenkins, 1960, pl. 1, fig. 8.

Globigerina euapertura Jenkins, Jenkins and Orr, 1972, pl. 9, figs. 1-6.

Stratigraphic Range: This species is rare but present in samples of P.22 age at Site 220 and of N.7-N.8 age at Site 219.

\section{Turborotalia (Turborotalia) humerosa humerosa (Takayanagi and Saito) (Plate 19, Figure 4)}

Globorotalia humerosa Takayanagi and Saito, 1962, pl. 28, figs. 1,

Globoquadrina humerosa (Takayanagi and Saito), Parker, 1967, pl. 24 , figs. 10,$11 ; \mathrm{pl}$. 25 , figs 1-6.

Globorotalia (Turborotalia) acostaensis humerosa Takayanagi and Saito, Blow, 1969, pl. 33, figs. 4, 5, 7-9; pl. 34, figs. 1-3. Stratigraphic Range: N.17 to early N.22.

\section{Turborotalia (Turborotalia) humerosa praepulleniatina (Brönnimann and Resig) (Plate 19, Figure 5)}

Pulleniatina praepulleniatina Brönnimann and Resig, 1971, pl. 20, figs. 1-6, 8; text-fig. 23 .

Remarks: The specimen illustrated here has a somewhat unusual final chamber that produces a mild resemblance to $T$. $(T$.) siakensis. More typical forms are present, however, and this hypotype is not unlike the specimen illustrated by Brönnimann and Resig (1971, pl. 
20, fig. 4). These authors placed this species in Pulleniatina, and there is little doubt that it is intermediate between that genus and Turborotalia. In its lack of a thickened, smooth wall, and the virtual absence of significant involution, however, its affinities seem closer to the latter.

Stratigraphic Range: Late N.17 to late N.18 at Site 219.

\section{Turborotalia (Turborotalia) humerosa trochoidea (Bizon and Bizon)}

(Plate 19, Figures 6, 7, 8)

Globorotalia acostaensis trochoidea Bizon and Bizon, 1965, pl. 4, fig. 12.

Remarks: The specimens observed here tend to have slightly more chambers in the final whorl, because of the addition of small, irregular chambers, than does the holotype. Even when these apparently gerontic chambers are absent, the umbilicus is very small. The inflated test suggests closer affinities with $T$. (T.) humerosa than with $T$. (T.) acostaensis.

Stratigraphic Range: Late N.18 to middle N.22 at Site 219.

\section{Turborotalia (Turborotalia) mayeri} (Cushman and Ellisor)

(Plate 19, Figures 9, 10)

Globorotalia mayeri Cushman and Ellisor, 1939, pl. 2, fig. 4 .

Globorotalia (Turborotalia) mayeri Cushman and Ellisor, Blow, 1969 , pl. 3, figs. 7-9 (holotype reillustrated).

Stratigraphic Range: At Site 219, this species was found in Core 13, Section 1 (N.10), and as reworked specimens in N.17 and N.18 assemblages, where it is common in some samples. It also occurs in the N.10 to N.11-N.12 interval at Site 223 .

\section{Turborotalia (Turborotalia) nigriniae, new species}

(Plate 20, Figures 1-5)

Description: The robust test is of moderate size, and consists of eight or more chambers arranged in a low trochospire, with four chambers in the final whorl. The wall texture is distinctly cancellate with well-developed pore pits. The dorsal surface is weakly convex, and the chambers are closely appressed. The earlier whorls are somewhat obscured, but the wall does not appear to be significantly thickened over the initial chambers. Dorsal sutures are slightly depressed, straight, and radial to slightly tangential. In outline the test is subquadrate, and the periphery is somewhat lobate and broadly rounded. The chambers are subglobular throughout. Ventral convexity is slightly greater than that of the dorsal side. The ventral sutures are straight and distinctly incised. The final chamber is typically larger and somewhat more inflated than the earlier chambers of the final whorl and projects slightly out of the plane of coiling. There is no distinct umbilicus, except in some occasional and somewhat atypical specimens (Plate 20, Figure 5), but a poorly defined umbilical depression is present. The large open aperture is umibilical to extraumbilical in position, but typically oblique in orientation, much as in $T$. (T.) cerroazulensis pomeroli (Toumarkine and Bolli). In rare specimens, however, it is laterally directed. The aperture is bordered by a broad, well-developed, imperforate rim.

The holotype is illustrated on Plate 20, Figures 1, 2, and 3 and was collected from Hole 219, Core 6 , Section $5,73-75 \mathrm{~cm}$. The age of this sample is late N.18 (Early Pliocene). Maximum diameter of the holotype is $0.34 \mathrm{~mm}$; axial elevation is $0.24 \mathrm{~mm}$.

Remarks: This distinctive species most resembles $T$. (T.) pseudopima, from which it differs in possessing a large, open, oblique aperture. It differs from $T$. $(T$.) continuosa in having a less-flattened dorsal side and more rapid increase in chamber size prior to the final whorl and in the shape and orientation of the aperture. In $T$. (T.) continuosa the aperture is more rounded ("comma-shaped") and is laterally rather than obliquely directed.

This species is named for Dr. Catherine Nigrini, a co-participant on DSDP Leg 23.

Stratigraphic Range: Middle N.18 to late N.19-N.20 (Early to mid-Pliocene).

\section{Turborotalia (Turborotalia) opima nana (Bolli)} (Plate 19, Figure 11)

Globorotalia opima nana Bolli, 1957 b, pl. 28 , fig. 3 .

Stratigraphic Range: This species was found in late P.18-P.19 at Site 219, and in P.20-P.21 to P.22 at Sites 220 and 223.
Turborotalia (Turborotalia) opima opima (Bolli)

(Plate 19, Figure 12)

Globorotalia opima opima Bolli, 1957b, pl. 28, figs. 1, 2. Stratigraphic Range: P.20-P.21 at Sites 220 and 223.

\section{Turborotalia (Turborotalia) pachyderma \\ (Ehrenberg)}

(Plate 19, Figure 13)

Aristerospira pachyderma Ehrenberg, 1861, pl. 1, fig. 4 .

Globigerina bulloides var. borealis Brady, 1881, p. 412 .

Globigerina bulloides var. borealis Brady, Banner and Blow, 1960b, pl. 3, fig. 4 .

Neogloboquadrina pachyderma (Ehrenberg), Collen and Vella, 1973 , pl. 1, figs. 7-10; pl. 2, figs. 1-3.

Remarks: Virtually all specimens are dextrally coiled.

Stratigraphic Range: This species occurs in small numbers from middle N.17 to N.23 at Site 219 .

\section{Turborotalia (Turborotalia) prasaepis (Blow)}

(Plate 20, Figure 7)

Globigerina ampliapertura euapertura Jenkins, Blow and Banner, in Eames et al., 1962, pl. 11, figs. E, F, G (holotype of $G$. prasaepis).

Globigerina prasaepis Blow, 1969, pl. 10, fig. 13; pl. 18, figs. 3-7. 223. Stratigraphic Range: P.18 to P.20-P.21 at Sites 219, 220, and

Turborotalia (Turborotalia) prolata (Bolli)

Globorotalia prolata Bolli, 1957a, pl. 15, figs. 24-26.

Stratigraphic Range: A single specimen was recovered from Sample 220-19-2, of P.8 age.

Turborotalia (Turborotalia)

pseudoampliapertura (Blow and Banner)

(Plate 20, Figure 8)

Globigerina pseudoampliapertura Blow and Banner, in Eames et al., pl. 17 , figs. A, E.

Globigerina pseudoampliapertura Blow and Banner, Blow, 1969, pl. 18 , figs. $8,9$.

Stratigraphic Range: P.18-P.19 at Site 219.

Turborotalia (Turborotalia) pseudopima (Blow)

(Plate 20, Figure 6)

Globorotalia (Turborotalia) acostaensis pseudopima Blow, 1969, pl. 35 , figs. 1-7.

Stratigraphic Range: Middle N.19-N.20 to uppermost N.22 at Site 219.

Turborotalia (Turborotalia) siakensis (LeRoy)

(Plate 20, Figures 9, 10)

Globorotalia siakensis LeRoy, 1939, pl. 3, figs. 30, 31 .

Globorotalia (Turborotalia) siakensis LeRoy, Blow, 1969, pl. 10, figs. 7-9 (holotype reillustrated); pl. 34 , figs. 4,5 .

Stratigraphic Range: This species was found in the N.7-N.8 to N.10 interval, and as reworked specimens throughout N.17 to N.22, at Site 219. It also occurs in P.22 at Site 220 and over the interval P. 22 to N.11-N.12 at Site 223 .

Turborotalia (Turborotalia) vincentae, new species (Plate 21, Figures 1-5)

Description: The test is large for species of this genus and consists of nine or more chambers arranged in a low trochospire. The final whorl consists of four or rarely five chambers, which increase slowly in size. The surface texture is cancellate, but wall thickening tends to produce a relatively smooth, regularly perforate appearance. The primary cancellate structure can be observed, on the holotype, in the wall of the penultimate chamber near the spiral suture. The chambers are much inflated, subglobular, and closely appressed, producing, particularly in four-chambered forms, a highly compact test. Dorsal sutures are straight, radial, and moderately depressed. The early chambers in the trochospire are obscured by secondary wall thickening, particularly over the initial whorl. The periphery is very broadly rounded and moderately lobate. Ventral sutures are distinct and deeply depressed. The final chamber, which is somewhat larger and more inflated than those immediately preceding it, projects slightly toward the umbilicus, out of the plane 
of coiling. The most distinctive feature of this species is an elongate and imperforate flap or flange, commonly bordered along part or all of its length by a thickened rim, which covers the umbilical region and extends in an anterior direction part or all of the way to the periphery. In specimens from which this flange has been removed (Plate 21, Figure 4), the umbilicus is seen to be a broad, deep depression, and the aperture is a low, elongate, extraumbilical to peripheral arch bordered by an imperforate region on the laterally directed apertural face.

The holotype is illustrated on Plate 21, Figures 1, 2, and 3 and was collected from Hole 219 , Core 7 , Section $2,73-75 \mathrm{~cm}$. The age of this sample is N.18 (Early Pliocene). Maximum diameter of the holotype is $0.45 \mathrm{~mm}$; the axial elevation is $0.30 \mathrm{~mm}$.

Remarks: This species most clearly resembles $T . \quad(T$. pseudopima Blow, to which it is probably related. $T$. (T.) pseudopima differs from $T$. (T.) vincentae in having a flatter dorsal side and a much less open umbilicus and in lacking the apertural-umbilical flange. $T$. vincentae differs from other species which possess a similar flange, notably $T$. (T.) humerosa humerosa (Takayanagi and Saito) and T. (T.) acostaensis tegillata (Brönnimann and Resig) in typically having fewer but much more inflated and closely appressed chambers in the final whorl.

This species is named for Dr. Edith Vincent, currently of the University of Southern California.

Stratigraphic Range: Middle N.17 to late N.18, ?N.21. The questionable occurrences may be reworked.

\section{Turborotalia (Turborotalia) sp. 1} (Plate 21, Figure 6)

Remarks: This small species is somewhat similar in form to $T$. (T.) birnageae, but is much older.

Stratigraphic Range: P.14 at Site 219.

\section{Genus TURBOROTALITA Blow and Banner, 1962}

Type Species: Truncatulina humilis Brady.

Remarks: This genus was defined on the basis of the bullate extension of the final chamber, but this appears to be a relatively poor basis for distinction. T. quinqueloba (Natland) is commonly placed in this genus, although the extension of the final chamber is often absent or poorly developed. A more satisfactory basis for recognition is the nature of the wall. All of the Turborotalita species examined have a microperforate wall marked, however, by large pores and short spines concentrated along the periphery. These spines are visible in the lectotype of the type species (Banner and Blow, 1960b, pl. 8, fig. 1) although they are commonly masked in many specimens by the thickened test wall.

\section{Turborotalita humilis (Brady)}

Truncatulina humilis Brady, 1884, pl. 94, fig. 7.

Truncatulina humilis Brady, Banner and Blow, 1960b, pl. 8, fig. 1 (lectotype).

Globigerinita humilis (Brady), Parker, 1962, pl. 10, figs. 1-25.

Turborotalita humilis (Brady), Brönnimann and Resig, pl. 21, figs. 6,7 .

Stratigraphic Range: N.18 to N.23 at Site 219.

\section{Turborotalita pumilio (Parker)}

(Plate 21, Figure 7)

Globorotalia pumilio Parker, 1962, pl. 6, figs. 2, 3.

Globanomalina (?) pumilio (Parker), Parker, 1967, pl. 18, fig. 5. Stratigraphic Range: Latest N.19-N.20 to N.23 at Site 219.

\section{Turborotalita "quinqueloba" (Natland)}

Globigerina quinqueloba Natland, 1938, pl. 6, fig. 7 .

Remarks: This form has been illustrated and discussed in detail elsewhere in this volume (Fleisher, Chapter 40 this volume, Plate 2, Figures $4,5,6$ ), and the reasons for questioning its assignment to Natland's taxon will only be summarized here. It has much more closely appressed and less flattened chambers and a much smaller test size than Globigerina quinqueloba Natland and does not resemble juvenile specimens dissected and illustrated by Asano et al., (1968). Finally, the morphotype identified by Natland is a cool water species, whereas $T$. "quinqueloba" is common in such warm-water regions as the Red Sea. These forms were noted here, but not studied in detail, and no new taxon is created for them at this time.

Stratigraphic Range: N.17 to N.23 at Site 219.

\section{ACKNOWLEDGMENTS}

Grateful appreciation is due to the following for helpful discussions during the preparation of this report: W. A. Berggren, A. Boersma, and B. ul Haq (Woods Hole Oceanographic Institution); F. L. Parker and D. Bukry (Scripps Institution of Oceanography); P. L. Steineck (S.U.N.Y., Purchase); and O. L. Bandy and E. Vincent (University of Southern California). R. Cifelli kindly provided access to the type collections available at the U.S. National Museum. J. Worral (University of Southern California) is responsible for the scanning electron micrographs.

This study was supported under Oceanographic Section, National Science Foundation NSF Grant GA-34145 and represents Contribution No. 330, Department of Geological Sciences, University of Southern California.

\section{REFERENCES}

Asano, K., Ingle, J. C., and Takayanagi, Y., 1968. Origin and development of Globigerina quinqueloba Natland in the North Pacific: Sci. Repts., Tohoku Univ., Sendai, 2nd Ser. (Geol.), v. 39, p. 213-241.

Bandy, O. L., 1960. General correlation of foraminiferal structure with environment: Int. Geol. Cong. Repts., XXI Sess., Norden, Pt. XXII, p. 7-19.

1964a. Cenozoic planktonic foraminiferal zonation: Micropaleontology, v. 10, p. 1-17.

1964b. Foraminiferal biofacies in sediments of Gulf of Batabano, Cuba, and their geologic significance: Am. Assoc. Petrol. Geol. Bull., v. 48, p. 1666-1679.

1964c. The type of Globigerina quadrilobata d'Orbigny: Contrib. Cushman Found. Foram. Res., v. 15 , p. 36-37.

1967. Cretaceous planktonic foraminiferal zonation: Micropaleontology, v. 13, p. 1-31.

1971. Recognition of Upper Miocene Neogene Zone 18, experimental Mohole, Guadalupe site: Nature, v. 233 , p. $476-478$.

1972a. A review of the calibration of deep-sea cores based upon species variation, productivity, and $160 / 180$ ratios of planktonic foraminifera-including sedimentation rates and climatic inferences. In Bishop, W. W. and Miller, J. A. (Eds.), Calibration of hominoid evolution: Scotland (Scottish Acad. Press), p. 37-61.

1972 b. Origin and development of Globorotalia (Turborotalia) pachyderma (Ehrenberg): Micropaleontology, v. 18, p. 294-318.

Bandy, O. L., Frerichs, W. E., and Vincent, E., 1967. Origin, development, and geologic significance of Neogloboquadrina Bandy, Frerichs, and Vincent, gen. nov.: Contrib. Cushman Found. Foram. Res., v. 18, pt. 4, p. 152-157.

Bandy, O. L. and Ingle, J. C., 1970. Neogene planktonic events and radiometric scale, California: Geol. Soc. Am. Spec. Paper 124, p. 131-172.

Banner, F. T. and Blow, W. H., 1959. The classification and stratigraphical distribution of the Globigerinaceae: Palaeontology, v. 2, p. 1-27.

1960a. The taxonomy, morphology and affinities of the genera included in the subfamily Hastigerininae: Micropaleontology, v. 6, p. 19-31.

1960 b. Some primary types of the species belonging to the superfamily Globigerinaceae: Contrib. Cushman Found. Foram. Res., v. 11, pt. 1, p. 1-41. 
1965. Progress in the planktonic foraminiferal biostratigraphy of the Neogene: Nature, v. 208, p. 1164-1166.

1967. The origin, evolution and taxonomy of the foraminiferal genus Pulleniatina Cushman, 1927: Micropaleontology, v. 13, p. 133-162.

Bé, A. W. H., 1969. Microstructural evidence of the close affinity of Globigerinella Cushman to Hastigerina Thomson: Int. Conf. Plankt. Microfossils, 1st, Proc., Brönnimann P. and Renz, H. H. (Eds.), Leiden (Brill), v. 1, p. 89-91.

Bé, A. W. H. and McIntyre, A., 1970. Globorotalia menardii flexuosa (Koch): An "extinct" foraminiferal subspecies living in the northern Indian Ocean: Deep-Sea Res., v. 17 , p. 595-601.

Bé, A. W. H. and Tolderlund, D. S., 1971. Distribution and ecology of living planktonic foraminifera in surface waters of the Atlantic and Indian Oceans. In Funnell, B. M. and Riedel, W. R., (Eds.), Micropaleontology of oceans: London, (Cambridge Univ. Press), p. 105-149.

Beckmann, J. P., 1953. Die Foraminifera der Oceanic Formation (Eocaen-Oligocaen) von Barbados, K1. Antillen: Eclog. Geol. Helv., v. 46, p. 302-412.

, 1957. Chiloguembelina Loeblich and Tappan and related Foraminifera from the lower Tertiary of Trinidad, B. W. I.: U. S. Nat. Museum Bull. 215, p. 83-96.

,1972. The foraminifera and some associated microfossils of Sites 135 to 144. In Hayes, D. E., Pimm, A. C., et al., Initial Reports of the Deep Sea Drilling Project, Volume 14: Washington (U.S. Government Printing Office), p. 389-420.

Berger, W. H., 1970. Planktonic foraminifera: selective solution and the lysocline: Marine Geol., v. 8, p. 111-138.

Berger, W. H. and von Rad, U., 1972, Cretaceous and Cenozoic sediments from the Atlantic Ocean floor. In Hayes, D. E., Pimm, A. C., et al., Initial Reports of the Deep Sea Drilling Project, Volume 14: Washington (U. S. Government Printing Office), p. 787-954.

Berggren, W. A., 1962. Stratigraphic and taxonomicphylogenetic studies of Upper Cretaceous and Paleogene planktonic foraminifera: Stockholm Univ., Contrib. Geol., v. 9, p. 107-130.

, 1968. Phylogenetic and taxonomic problems of some Tertiary planktonic foraminiferal lineages: Tulane Stud. Geol., v. 6. p. 1-22.

1969a. Paleogene biostratigraphy and planktonic foraminifera of Northern Europe: Int. Conf. Plankt. Microfossils 1st, Proc., Brönnimann, P. and Renz, H. H. (Eds.), Leiden (Brill), v. 1, p. 121-160.

1969b. Rates of evolution in some Cenozoic planktonic foraminifera: Micropaleontology, v. 15, p. 351-365.

, 1971a. Multiple phylogenetic zonations of the Cenozoic based on planktonic foraminifera: Planktonic Conf., 2nd, Roma, 1970, Proc., Farinacci, A. (Ed.), Rome (Edizioni Tecnoscienza),v. 1, p. 41-56.

1971 b. Paleogene planktonic foraminiferal faunas on Legs I-IV (Atlantic Ocean), JOIDES Deep Sea Drilling Program - a synthesis: Planktonic Conf., 2nd (Edizioni Roma, 1970, Proc., Farinacci, A. (Ed.), Rome Tecnoscienza), v. 1. 57-77.

1971c. Tertiary boundaries and correlations: In Funnel, B. M. and Riedel, W. R., (Eds.), Micropaleontology of oceans: London (Cambridge Univ. Press), p. 693-809.
1972. A Cenozoic time-scale-some implications for regional geology and paleobiogeography: Lethaia, v. 5, p. 195-215.

1973. The Pliocene time scale: calibration of planktonic foraminiferal and calcareous nannoplankton zones: Nature, v. 243, p. 391-397.

Berggren, W. A., Olsson, R. K., and Reyment, R. A., 1967. Origin and development of the foraminiferal genus Pseudohastigerina Banner and Blow, 1959: Micropaleontology, v. 13 , p. $265-288$.

Blow, W. H., 1956. Origin and evolution of the foraminiferal genus Orbulina d'Orbigny: Micropaleontology, v. 2, p. 57-70.

1959. Age, correlation, and biostratigraphy of the upper Tocuyo (San Lorenzo) and Pozon Formations, eastern Falcón, Venezuela: Am. Paleont. Bull., v. 39, p. 67-251.

1965. Clavatorella, a new genus of the Globorotaliidae: Micropaleontology v. 11, p. 365-368. 1969. Late Middle Eocene to Recent planktonic foraminiferal biostratigraphy: Int. Conf. Plankt. Microfossils, 1st, Proc., Brönnimann, P. and Renz, H. H. (Eds.), Leiden (Brill), v. 1, p. 199-422.

1970. Validity of biostratigraphic correlations based on the Globigerinacea: Micropaleontology, v. 16, p. 257-268.

1971. Deep Sea Drilling Project, Leg 6 foraminifera from selected samples. In Fischer, A. G. et al., Initial Reports of the Deep Sea Drilling Project, Volume 6: Washington (U.S. Government Printing Office), p. 1013-1026.

Blow, W. H. and Banner, F. T., 1966. The morphology, taxonomy and biostratigraphy of Globorotalia barisanensis LeRoy, Globorotalia fohsi Cushman and Ellisor, and related taxa: Micropaleontology, v. 12, p. 286-302.

Blow, W.H. and Saito, T., 1968, The morphology and taxonomy of Globigerina mexicana Cushman, 1925: Micropalentology, v. 14, p. 357-360.

Bolli, H. M., 1957a. The genera Globigerina and Globorotalia in the Paleocene-lower Eocene Lizard Springs formation of Trinidad, B. W. I.: U.S. Nat. Museum Bull. 215, p. 61-82.

1957b. Planktonic Foraminifera from the Oligocene-Miocene Cipero and Lengua formations of Trinidad, B.W. I.: U. S. Nat. Museum Bull. 215, p. 97-124.

, 1957c. Planktonic foraminifera from the Eocene Navet and San Fernando formations of Trinidad, B. W. I.: U. S. Nat. Museum Bull. 215, p. 155-172.

1966. Zonation of Cretaceous to Pliocene marine sediments based on planktonic foraminifera: Bol. Inform., Asoc. Venez. Geol., Min., Petrol., v. 9, p. 3-32. 1967. The subspecies of Globorotalia fohsi Cushman and Ellisor and the zones based on them: Micropaleontology, v. 13 , p. 502-512.

1970. The foraminifera of Sites 23-31, Leg 4. In Bader, R. G. et al., Initial Reports of the Deep Sea Drilling Project, Volume 4: Washington (U.S. Government Printing Office), p. 577-643. 1972. The genus Globigerinatheka Brönnimann: Jr. Foram. Res., v. 2, p. 109-136.

Bolli, H. M. and Bermúdez, P. J., 1965. Zonation based on planktonic foraminifera of Middle Miocene to Pliocene warm-water sediments: Bol. Inform., Asoc. Venez. Geol., Min., Petrol., v. 8, p. 121-149.

Bolli, H. M., Loeblich, A. R., and Tappan, H., 1957. Planktonic foraminiferal families Hantkeninidae, Orbulinidae, 
Globorotaliidae, and Globotruncanidae: U. S. Nat. Museum Bull. 215, p. 3-50.

Boltovskoy, E., 1971. Patchiness in the distribution of planktonic foraminifera: Planktonic Conf., 2nd, Roma 1970, Proc., Farinacci, A. (Ed.), Rome (Edizioni Tecnoscienza), p. 107-115.

Brönnimann, P. and Resig, J., 1971. A Neogene globigerinacean biochronologic time-scale of the Southwestern Pacific. In Winterer, E. L. et al., Initial Reports of the Deep Sea Drilling Project, Volume 7; Washington (U. S. Government Printing Office), p. 1235-1469.

Bukry, D., 1971. Cenozoic calcareous nannofossils from the Pacific Ocean: Trans. San Diego Soc. Nat. Hist., v. 16, p. 303-328.

Ciaranfi, N. and Cita, M. B., 1973. Paleontological evidence of changes in the Pliocene climates. In Ryan, W. B. F., Hsü, K. J., et al., Initial Reports of the Deep Sea Drilling Project, Volume 13: Washington (U. S. Government Printing Office), p. 1387-1399.

Cifelli, R., 1969. Radiation of Cenozoic planktonic foraminifera: Systematic Zool., v. 18, p. 154-168. 1972. The holotypes of Pulvinulina crassata var. densa Cushman and Globigerina spinuloinflata Bandy: Je.Foram. Res., v. 2, p. 157-159.

Cita, M. B., 1973. Pliocene biostratigraphy and chronostratigraphy. In Ryan, W. B. F., Hsü, K. J., et al., Initial Reports of the Deep Sea Drilling Project, Volume 13: Washington (U. S. Government Printing Office), p. 1343-1380.

Collen, J. D. and Vella, P., 1973. Pliocene planktonic foraminifera, southern North Island, New Zealand: Jr. Foram. Res., v. 3, p. 13-29.

Cordey, W. G., 1967. The development of Globigerinoides ruber (d'Orbigny 1839) from the Miocene to Recent: Palaeontology, v. 10, p. 647-659. 1968. A new Eocene Cassigerinella from Florida: Paleontology, v. 11, p. 368-370.

Cordey, W. G., Berggren, W. A., and Olsson, R. K., 1970. Phylogenetic trends in the planktonic foraminiferal genus Pseudohastigerina Banner and Blow, 1959: Micropaleontology, v. 16 , p. $235-242$.

Cushman, J. A., 1918. Some Miocene Foraminifera of the Coastal Plain of the United States: U. S. Geol. Surv. Bull. 676, p. 57.

Cushman, J. A. and Bermúdez, P. J., 1937. Further new species foraminifera from the Eocene of Cuba: Contrib. Cushman Lab. Foram. Res., v. 13, pt. 1, p. 1-29.

1949. Some Cuban species of Globorotalia: Contrib. Cushman Lab. Foram. Res., v. 25, pt. 2, p. 26-44.

Eames, F. E., Banner, F. T., Blow, W. H., and Clarke, W. J., 1962. Fundamentals of Mid-Tertiary stratigraphical correlation: London (Cambridge Univ. Press), p. 1-151.

El-Naggar, Z. R., 1966. Stratigraphy and planktonic Foraminifera of the Upper Cretaceous-Lower Tertiary succession in the Esna-Idfu region, Nile Valley, Egypt, U. A. R.: Brit. Mus. (Nat. Hist.), Bull. Supp. 2, p. 1-291. 1969. New suggestions for the division and correlation of Paleocene strata by the use of planktonic foraminifera: Conf. Plankt. Microfossils, 1st, Proc., Brönnimann, P. and Renz, H. H. (Eds.), Leiden. v. 2, p. 182-201.

1971. On the classification evolution and stratigraphical distribution of the Globigerinacea: Planktonic Conf., 2nd, Roma 1970, Proc., Farinacci, A. (Ed.), Rome (Edizioni Tecnoscienza), v. 1, p. 421-476.
Fahmy, S. E., Krasheninnikov, V., Mikhailov, I., and Samodurov, V., 1969. Biostratigraphy of Paleogene deposits: African Micropal. Colloq., 3rd, Proc., Nat. Inform. Doc. Centre, Cairo, p. 477-484.

Fleisher, R. L., 1969. Secondary calcification in Globorotalia menardii (Foraminiferida): Am. Assoc. Petrol. Geol. Bull., v. 53, p. 466 (abstract).

Frerichs, W. E., 1971. Evolution of planktonic foraminifera and paleo-temperatures: J. Paleont., v. 45, p. 963-968.

Gartner, S., 1973. Absolute chronology of the Late Neogene calcareous nannofossil succession in the Equatorial Pacific: Geol. Soc. Am. Bull., v. 84, p. 2021-2034.

Glass, B., Ericson, D. B., Heezen, B. C., Opdyke, N. D., and Glass, J.A., 1967. Geomagnetic reversals and Pleistocene chronology: Nature, v. 216, p. 437-442.

Gohrbandt, K.H.A., 1967. Some new planktonic foraminiferal species from the Austrian Eocene: Micropaleontology, v. 13, p. 319-326.

Hagn, H. and Lindenberg, H. G., 1969. Revision der von C. W. Gümbel 1868 aus dem Eozä des bayerischen Alpenvorlandes beschriebenen planktonischen Foraminiferen: Int. Conf. Plankt. Microfossils, 1st, Proc., Brönnimann, P. and Renz, H. H. (Eds.), Leiden (Brill), v. 2, p. 229-249.

Hofker, J., 1954. Morphology of Globigerinatella insueta Cushman and Stainforth: Conbrib. Cushman Found. Foram. Res., v. 5, pt. 4, p. 151-152.

- 1963.Cassigerinella Pokorný, 1955, and Islandiella Norvang, 1958: Micropaleontology, v. 9, p. 321-324.

Hornibrook, N. de B., 1961. Tertiary Foraminifera from Oamaru District (N. Z.), Part 1 - Systematics and distribution: New Zealand Geol. Surv. Paleont. Bull. 34 (1), p. 1-192.

Jenkins, D. G., 1964. A history of the holotype, ontogeny, and dimorphism of Globorotaloides turgida (Finlay): Contrib. Cushman Found. Foarm. Res., v. 15, pt. 3, p. 117-121.

1965a. The origin of the species Globigerinoides trilobus (Reuss) in New Zealand: Contrib. Cushman Found. Foram. Res., v. 16, pt. 3, p. 116-120.

1965b. Planktonic foraminiferal zones and new taxa from the Danian to Lower Miocene of New Zealand: New Zealand J. Geol. Geophys., v. 8, p. 1088-1126.

, 1965c. A re-examination of Globorotalia collactea Finlay, 1939: New Zealand J. Geol. Geophys., v. 8, p. $843-848$.

, 1971. New Zealand Cenozoic planktonic foraminifera: New Zealand Geol. Surv. Paleont. Bull. 42, p. 1-278.

Jenkins, D. C. and Orr, W. N., 1971. Cenozoic planktonic foraminiferal zonation and the problem of test solution. Rev. Espan. Micropal., v. 3, p. 301-304. , 1972. Planktonic foraminiferal biostratigraphy of the eastern Equatorial Pacific-DSDP Leg 9: In Hollister, C. D., Ewing, J. I., et al., Initial Reports of the Deep Sea Drilling Project, Volume 9: Washington (U. S. Government Printing Office), p. 1060-1193.

Keany, J. and Kennett, J.P., 1972. Pliocene-early Pleistocene paleoclimatic history recorded in AntarcticSubantarctic deep-sea cores: Deep-Sea Rès., v. 19, p. 529-548.

Kierstead, C. H., Leidy, R. R.D., Fleisher, R. L., and Boersma, A., 1969. Neogene zonation of tropical Pacific cores: Int. Conf. Plankt. Microfossils, 1st Proc., 
Brönnimann, P. and Renz, H. H. (Eds.), Leiden (Brill), v. 2, p. 328-338.

Kleinpell, R., 1972. A historical review of Pacific Coast micropaleontology: Proc. Pacific Coast Mio. Biostrat. Symp., Pacific Sect., S. E. P. M., p. 89-110.

Krasheninnikov, V., 1971. Cenozoic foraminifera. In Fischer, A. G. et al., Initial Reports of the Deep Sea Drilling Project, Volume 6: Washington (U.S. Government Printing Office), p. 1055-1068.

Krasheninnikov, V. A. and Ponikarov, V. P., 1965. Zonal stratigraphy of Paleogene in the Nile Valley: U. A. R. Geol. Surv. Paper 32, p. 1-26.

Lamb, J. L., 1969. Planktonic foraminiferal datums and Late Neogene epoch boundaries in the Mediterranean, Caribbean, and Gulf of Mexico: Trans. Gulf Coast Assoc. Geol. Soc., v. 19, p. 559-578.

Lamb, J. L. and Beard, J. H., 1972. Late Neogene planktonic foraminifers in the Caribbean, Gulf of Mexico, and Italian stratotypes: Univ. Kansas Paleont. Contrib., Art. 57 (protozoa 8), p. 1-67.

Lee, J. J., Freudenthal, H. D., Kossoy, V., and Bé, A. W. H., 1965. Cytological observations on two planktonic foraminifera, Globigerina bulloides d'Orbigny, 1826, and Globigerinoides ruber (d'Orbigny, 1839) Cushman, 1927: J. Protozool., v. 12, p. 531-542.

Lindenberg, H. G., 1969. Statistical notes on the variability of Globigerina eocaena Gümbel, 1868, from the Paleogene of the Bavarian Alps: Int. Conf. Plankt. Microfossils, 1st, Proc., Brönnimann, P. and Renz, H. H. (Eds.), Leiden (Brill), v. 2, p. 343-365.

Lipps, J. H., 1964. Miocene planktonic foraminifera from Newport Bay, California: Tulane Studies Geol., v. 2, p. 109-133.

1966. Wall structure, systematics, and phylogeny studies of Cenozoic planktonic foraminifera: J. Paleont., v. 40 , p. $1257-1273$.

Loeblich, A. R. and Tappan, H., 1957. Planktonic foraminifera of Paleocene and Early Eocene age from the Gulf and Atlantic Coastal Plain: U. S. Nat. Museum Bull. 215, p. 173-198.

, 1964, Treatise on Invertebrate Paleontology, Part C, Protista 2, Sarcodina, chiefly "Thecamoebians" and Foraminiferida: Geol. Soc. Am., R. C. Moore (Ed.), 2 vols.

Luterbacher, H., 1964. Studies in some Globorotalia from the Paleocene and Lower Eocene of the Central Apennines: Eclog. Geol. Helv., v. 57, p. 631-730.

1972. Paleocene and Eocene planktonic foraminifera, Leg 11, DSDP. In Hollister, C. D., Ewing, J. I. et al., Initial Reports of the Deep Sea Drilling Project, Volume 11: Washington (U. S. Government Printing Office), p. 547-550.

McGowran, B., 1968. Reclassification of early Tertiary Globorotalia: Micropaleontology, v. 14, p. 179-198.

1971. On foraminiferal taxonomy: Planktonic Conf., 2nd, Roma 1970, Proc., Farinacci, A. (Ed.), Rome (Edizioni Tecnoscienza), v. 2, p. 813-820.

McKenzie, D. and Sclater, J. G., 1971. The evolution of the Indian Ocean since the Late Cretaceous: Geophys. J. Roy. Astron. Soc., v. 25, p. 437-528.

Meyer, W. C., 1973. Late Pleistocene and Holocene paleoceanography of the Red Sea: Unpublished M. S. thesis, University of Southern California.

Olsson, R. K., 1970. Planktonic foraminifera from base of Tertiary, Millers Ferry, Alabama: J. Paleont., v. 44, p. 598-604.

, 1971. The logarithmic spire in planktonic foraminifera: its use in taxonomy, evolution, and paleocology: Trans. Gulf Coast Assoc. Geol. Soc., v. 21, p. 419-432.

1972. Growth changes in the Globorotalia fohsi lineage: Eclog. Geol. Helv., v. 65, p. 165-184.

Orr, W. N., 1967. Secondary calcification in foraminiferal genus Globorotalia: Science, v. 157, p. 1554-1555.

Parker, F. L., 1962. Planktonic foraminiferal species in Pacific sediments: Micropaleontology, v. 8, p. 219-254. 1965. Irregular distribution of planktonic foraminifera and stratigraphic correlation. In Sears, M. (Ed.), Progress in oceanography:v. 3, p. 267-272.

1967. Late Tertiary biostratigraphy (planktonic foraminifera) of tropical Indo-Pacific deep-sea cores: Am. Paleont. Bull., v. 52, p. 115-208.

1973. Living planktonic foraminifera from the Gulf of California: J. Foram. Res., v. 3, p. 70-77.

Parker, F. L., and Berger, W. H., 1971. Faunal and solution patterns of planktonic Foraminifera in surface sediments of the South Pacific: Deep-Sea Res., v. 18, p. 73-107.

Poag, C.W., 1972. Neogene planktonic foraminiferal biostratigraphy of the western North Atlantic: DSDP Leg 11. In Hollister, C. D., Ewing, J. J., et al., Initial Reports of the Deep Sea Drilling Project, Volume 11; Washington (U.S. Government Printing Office), p. 483-543.

Postuma, J. A., 1971. Manual of Planktonic Foraminifera: Amsterdam (Elsevier Publishing Co.), p. 1-420.

Proto Decima, F. and Bolli, H. M., 1970. Evolution and variability of Orbulinoides beckmanni (Saito): Eclog. Geol. Helv., v. 63, p. 883-905.

Rajagopalan, N., 1968. A re-study of the Pondicherry Formation: Geol. Soc. India Mem., no. 2, p. 128-129.

Raju, D. S. N., 1970. Zonal distribution of selected foraminifera in the Cretaceous and Cenozoic sediments of Cauvery basin and some problems of Indian biostratigraphic classification: Centre Adv. Stud. Geol., Panjab Univ., Pub. no. 7, p. 85-110.

1971. Upper Eocene to Early Miocene planktonic foraminifera from the subsurface sediments in Cauvery basin, South India: Jb. Geol. B. A., Sond. 17, p. 7-68.

Riedel, W. R. and Sanfilippo, A., 1970. Radiolaria, Leg 4, Deep Sea Drilling Project. In Bader, R. G. et al., Initial Reports of the Deep Sea Drilling Project, Volume 4: Washington (U.S. Government Printing Office), p. 503-575.

1971. Cenozoic Radiolaria from the western tropical Pacific. In Winterer, E. L. et al., Initial Reports of the Deep Sea Drilling Project, Volume 7: Washington (U. S. Government Printing Office), p. 1529-1672.

Samanta, B. K., 1968. The age of the youngest marine horizon present in Pondicherry, South India: Geol. Soc. India, Mem. no. 2, p. 120-127.

Shutskaya, E. K., 1958. Variation of some Lower Paleogene planktonic foraminifera of the Northern Caucasus: Voprosi Mikropaleont., Akad. Nauk SSR, Otdel. Geol.-Geog. Nuak, Geol. Inst., no. 2, p. 84-90 (in Russian).

Sieglie, G. A., 1973. Revision of mid-Tertiary stratigraphy of southwestern Puerto Rico: Am. Assoc. Petrol. Geol. Bull., v. 57, p. 405-406.

Srinivasan, M. S. and Sharma, V., 1969. A new planktonic foraminifer from the Late Tertiary of Car Nicobar Island, Bay of Bengal: Contrib. Cushman Found. Foram. Res., v. 20, pt. 3, p. 100-101.

Steineck, P. L., 1969. Lineage genera classification of lower Paleogene planktonic foraminifera: Am. Assoc. Petrol. Geol. Bull., v. 53, p. 465 (abstract). 
1971a. Middle Eocene refrigeration: new evidence from California planktonic foraminiferal assemblages: Lethaia, v. 4, p. 125-129.

1971 b. Phylogenetic reclassification of Paleogene planktonic foraminifera: Texas Je. Sci., v. 23, p. 167-178.

Steineck, P. L. and Darrell, J. H., 1971. Cassigerinella winniana (Howe), from the Cook Mountain Eocene, Louisiana: Micropaleontology, v. 17, p. 357-360.

Steineck, P. L., and Gibson, J. M., 1971. Age and correlation of the Eocene Ulatisian and Narizian Stages, California: Geol. Soc. Am. Bull., v. 82, p. 477-480.

Subbotina, N. N., 1953. Fossil Foraminifera of the U.S.S.R.-Globigerinidae, Hantkeninidae, and Globorotaliidae: (in Russian) (English translation, 1971, Collett's, Ltd., London).

Theyer, F., 1973. Globorotalia truncatulinoides Datum Plan: evidence for a Gauss (Pliocene) age in subantarctic cores: Nature Phys. Sci., v. 241, p. 142-145.

Todd, R., 1961. On selection of lectotypes and neotypes: Contrib. Cushman Found. Foram. Res., v. 12, pt. 4, p. 121-122.

Tolderlund, D. S. and Bé, A.W. H., 1971. Seasonal distribution of planktonic foraminifera in the western North Atlantic: Micropaleontology, v. 17, p. 297-329.
Toumarkine, M. and Bolli, H. M., 1970. Evolution de Globorotalia cerroazulensis (Cole) dans l'Eocène Moyen et Supérieur de Possagno (Italie): Rev. Micropal., v. 13, p. 131-145.

van Heerden, J., 1970. The taxonomic value of spiral accessory apertures in some Tertiary taxa: Rev. Espan. Micropal., v. 2, p. 165-172.

Vincent, E., 1972. Oceanography and Late Quaternary planktonic foraminifera, southwestern Indian Ocean: Unpublished Ph.D. dissertation, University of Southern California.

von der Borch, C. C., Sclater, J. G., Gartner, S., Hekinian, R., Johnson, D. A., McGowran, B., Pimm, A. C., Thompson, R. W., and Veevers, J. J., 1972. Deep Sea Drilling Project, Leg 22: Geotimes, June 1972, p. 15-17.

Zobel, B., 1971. Foraminifera from plankton tows, Arabian Sea: areal distribution as influenced by ocean water masses: Planktonic Conf., 2nd, Roma 1970, Proc., Farinacci, A. (Ed.), Rome (Edizioni Tecnoscienza), v. 2, p. 1323-1335.

1973. Biostratigraphische Untersuchungen an Sedimenten des indischpakistanischen Kontinentalrandes (Arabisches Meer): "Meteor" Forsch.-Ergeb., Reihe C., p. 9-73. 


\section{Plate Explanations}

" $D$ " indicates the maximum diameter or length of the specimen measured on the illustrated orientation. The scale bar represents 0.1 millimeter except where noted on the plates. In cases of confusion, the measured diameter is definitive. All illustrations are of different specimens unless otherwise indicated. All illustrated specimens, as well as unillustrated paratypes of new species, have been deposited in the collections of the U.S. National Museum, Washington, D.C.

\section{PLATE 1}
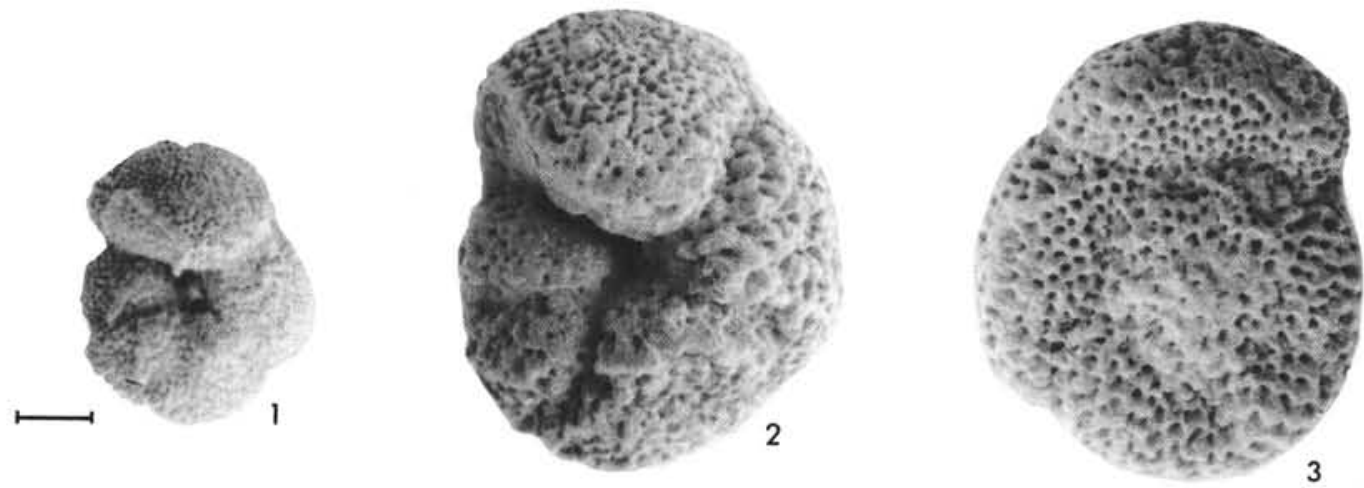

3

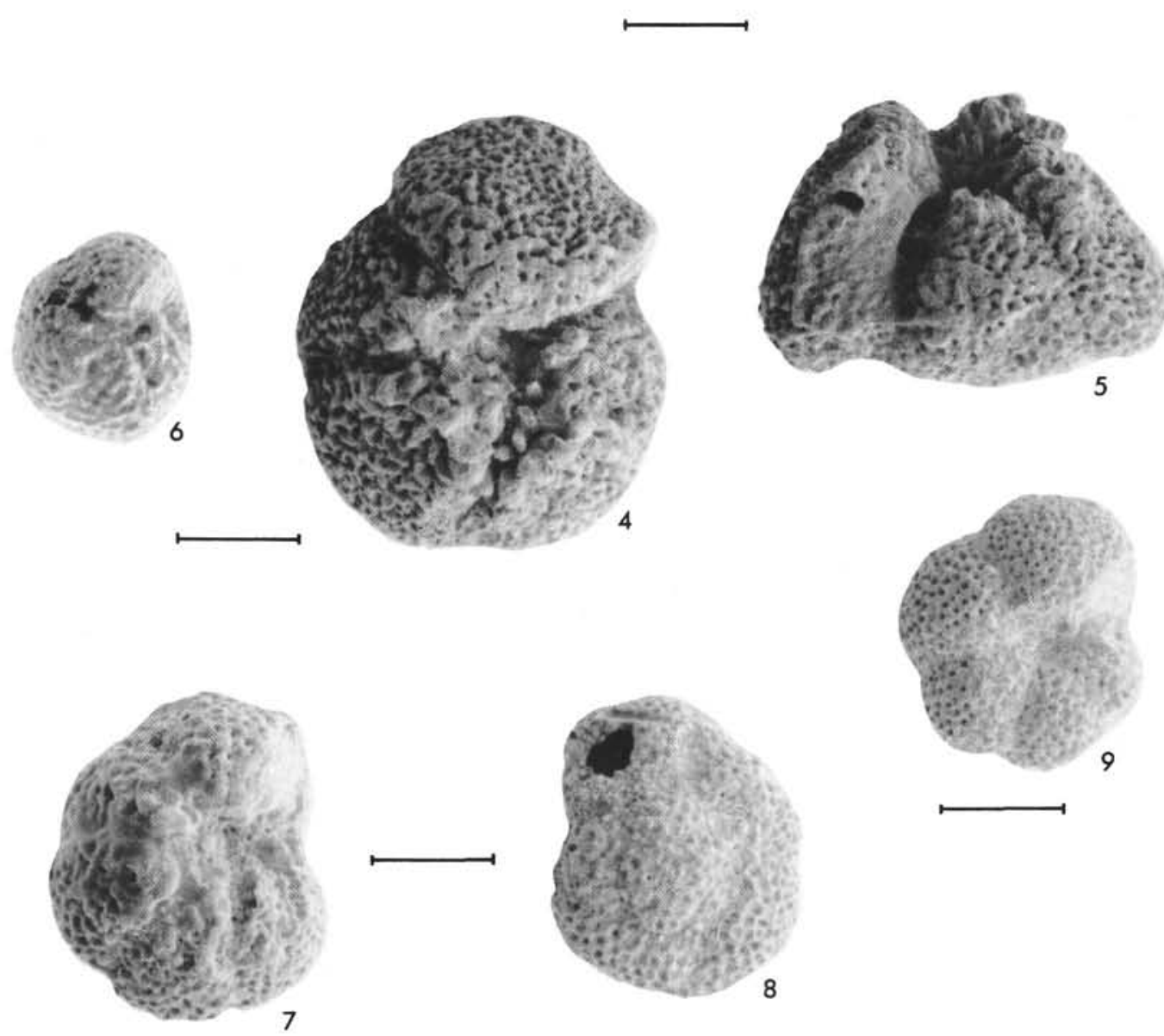

PLATE 1. All specimens except Figure 1 are illustrated at the same magnification. Figure 1 Acarinina apanthesma (Loeblich and Tappan), ventral view. Sample 220-18-3, 138-140 cm; Zone P.8. D =0.35 mm. Figures 2-5 Acarinina boudreauxi, n. sp. All from Sample 219-19-6, 51-53 cm; Zone P.11. Figure 2 Holotype, ventral view. $D=0.35$ mm. Figure 3 Holotype, dorsal view. Figure 4 Large paratype, ventral view. $D=0.39 \mathrm{~mm}$. Figure 5 Paratype, lateral (apertural) view. $D=0.35 \mathrm{~mm}$. Figure 6 Acarinina convexa (Subbotina), ventral view. Sample 220-18-3, $138-140 \mathrm{~cm}$, Zone P.8. D = 0.18 mm. Figures 7, 8 Acarinina mattseensis mattseensis (Gohrbandt). Both from Sample 220-16-2, 68-70 cm; Zone P.8. Figure 7 Ventral view. $D=0.29 \mathrm{~mm}$. Figure 8 Dorsal view. $D=0.27 \mathrm{~mm}$. Figure 9 Acarinina pentacamerata (Subbotina), ventral view. Sample 220-18-3, 138-140 cm; Zone P.8. $D=0.26 \mathrm{~mm}$. 


\section{PLATE 2}
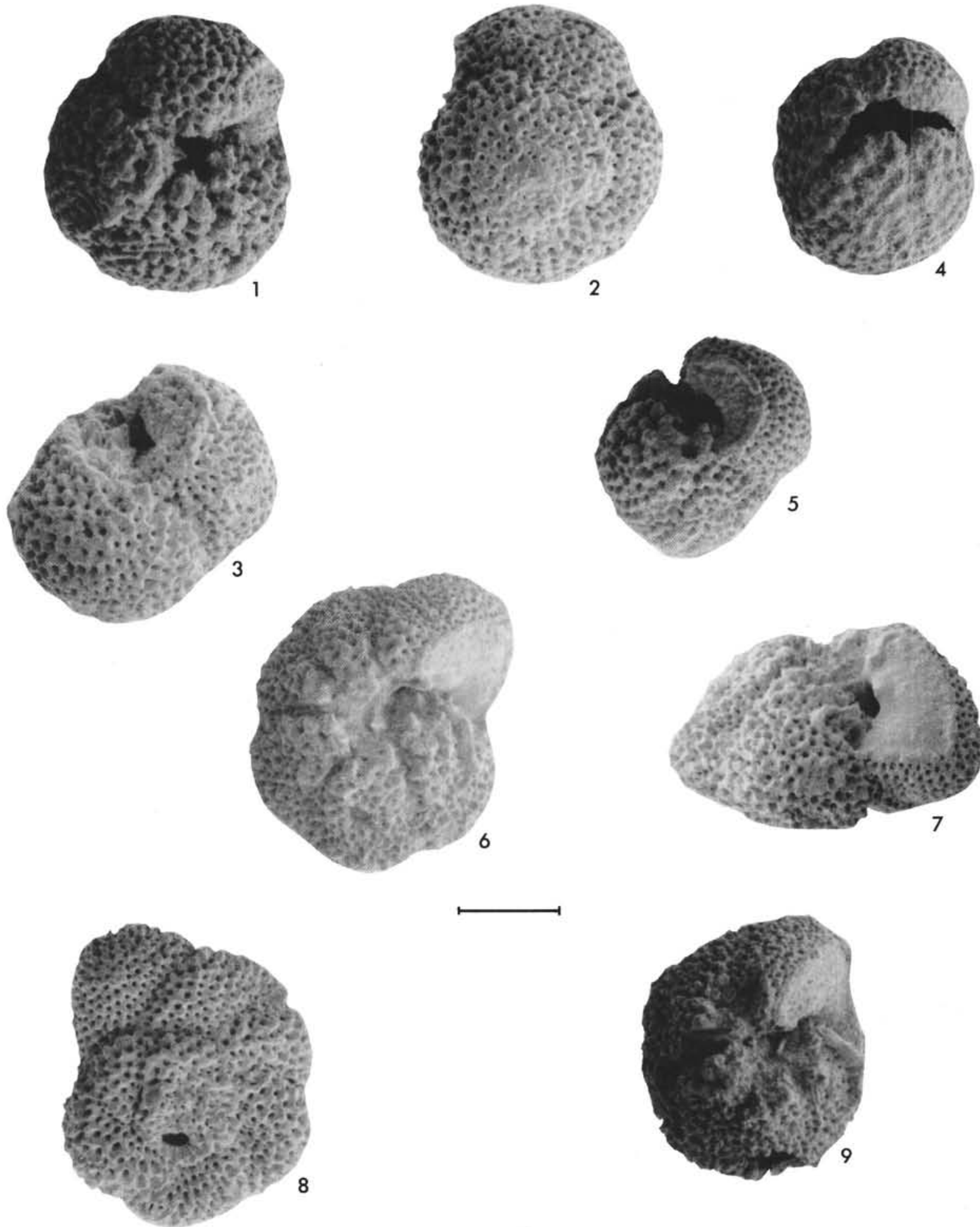

PLATE 2. All specimens are illustrated at the same magnification. Figures 1-5 Acarinina mattseensis alticonica, n. sp. All from Sample 220-16-2, 68-70 cm; Zone P.8. Figure 1 Holotype, ventral view. $D=0.31 \mathrm{~mm}$. Figure 2 Holotype, dorsal view. Figure 3 Holotype, lateral (apertural) view. Figure 4 Paratype, ventral view. $D=0.27 \mathrm{~mm}$. This specimen represents a commonly observed morphotype with an elongate, slit-like umbilicus and a relatively high spire similar to that illustrated in Figure 5. Aperture slightly retouched. Figure 5 Paratype, lateral (apertural) view. $D=0.26 \mathrm{~mm}$. Figures 6-9 Acarinina planodorsalis, n. sp. Figure 6 Holotype, ventral view. Sample 219-20-4, 52-54 cm; Zone P.11. D = 0.35 mm. Figure 7 Holotype, lateral (apertural) view. Figure 8 Holotype dorsal view. Figure 9 Small paratype, ventral view. Sample 219-20-6, $51-53 \mathrm{~cm}$; Zone P.11. $D=0.30 \mathrm{~mm}$. 

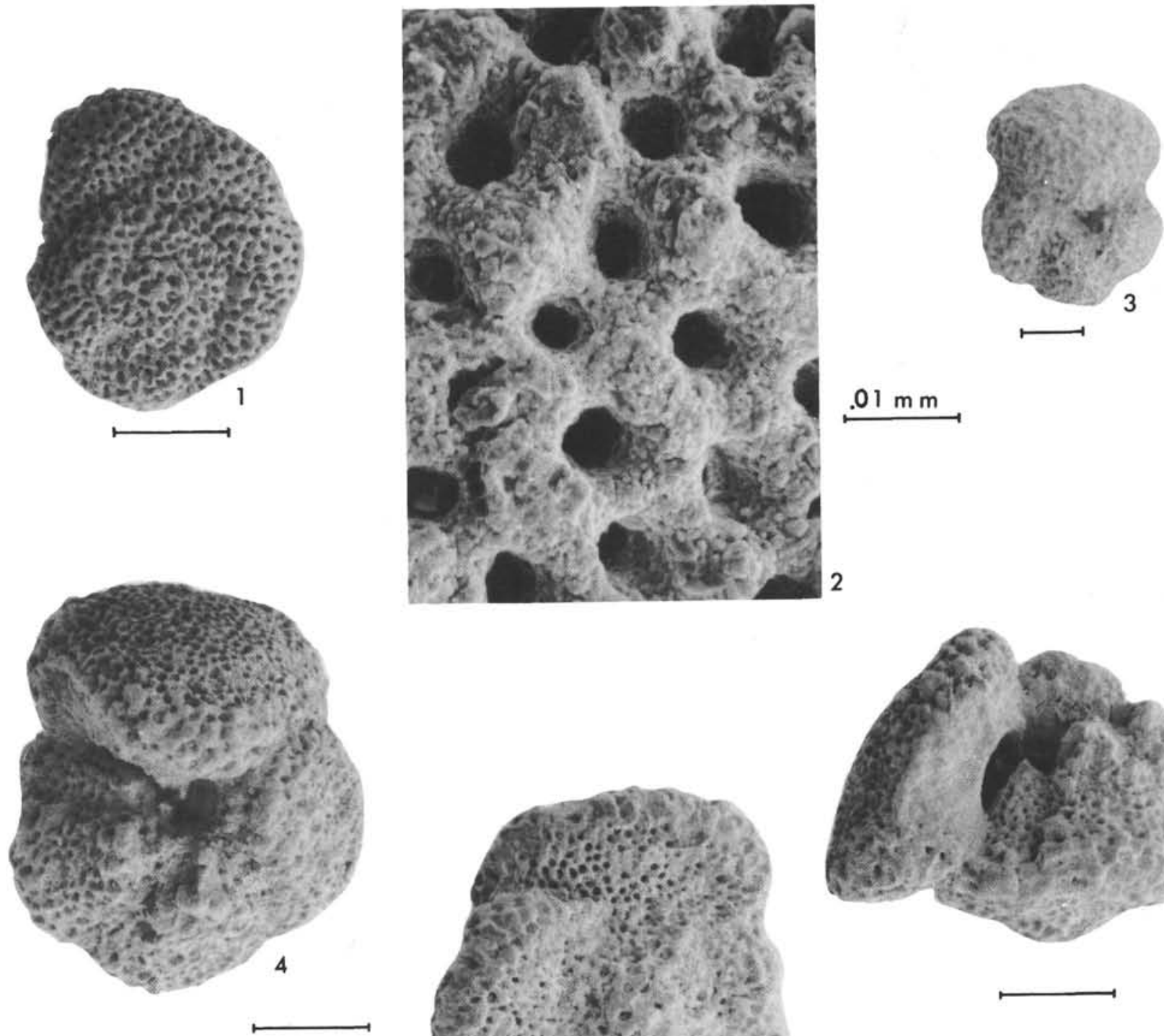

\section{$.01 \mathrm{~m} \mathrm{~m}$}
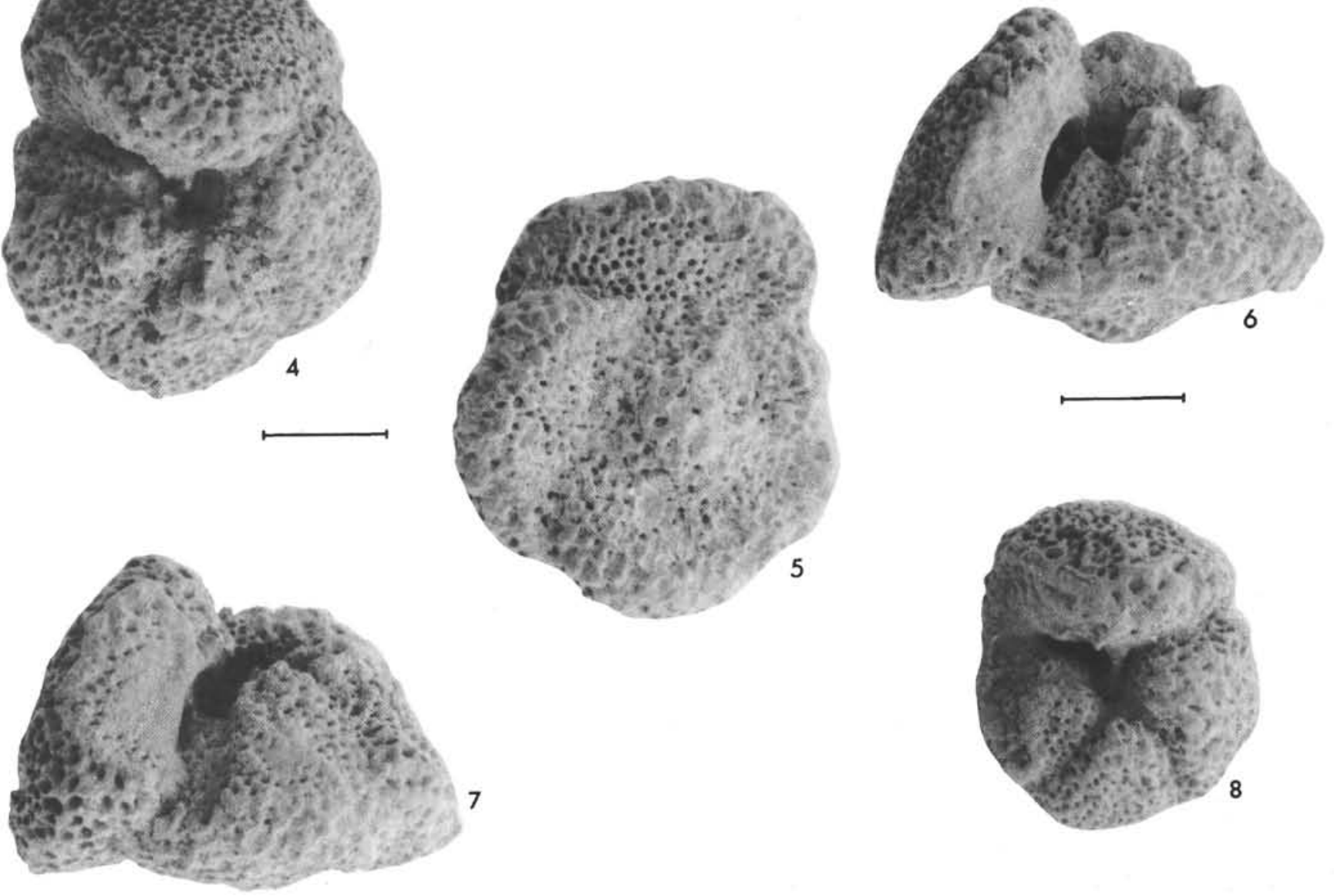

PLATE 3. Figures 1, 2 Acarinina planodorsalis, n. sp. Figure 1 Paratype, dorsal view. Sample 219-204, 52-54 cm; Zone P. 11. $D=0.31 \mathrm{~mm}$. Figure 2 Detail of dorsal wall of final chamber, same specimen as Figure 1. Pore pits are present, but obscured by thickening of interpore ridges. Figure 3. Acarinina quetra (Bolli), ventral view. Sample 220-18-3, 138-140 cm; Zone P.8. $D=0.43 \mathrm{~mm}$. Figures 4-8 Acarinina punctocarinata, n. sp. All from Sample 220-12-5, 70-72 cm; Zone P. 11 . Figure 4 Holotype, ventral view. $D=0.39 \mathrm{~mm}$. Figure 5 Holotype, dorsal view. Figure 6 Holotype, lateral (apertural) view. Figure 7 Paratype, lateral (apertural) view. $D=0.41 \mathrm{~mm}$. Figure 8 Small paratype, ventral view. $D=0.30 \mathrm{~mm}$. 
PLATE 4

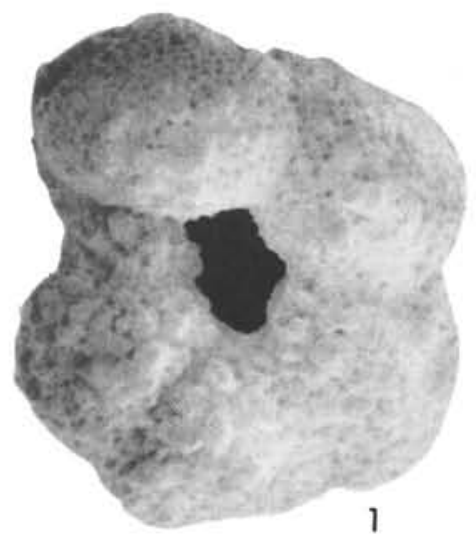

1

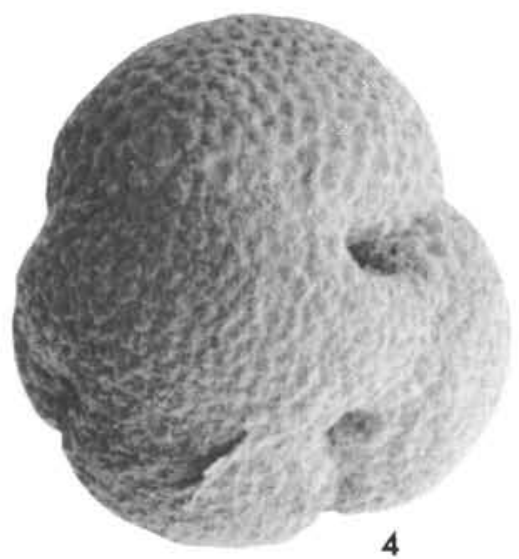

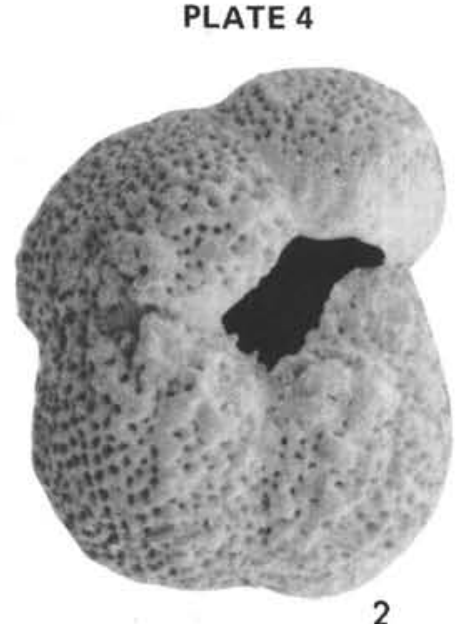

2
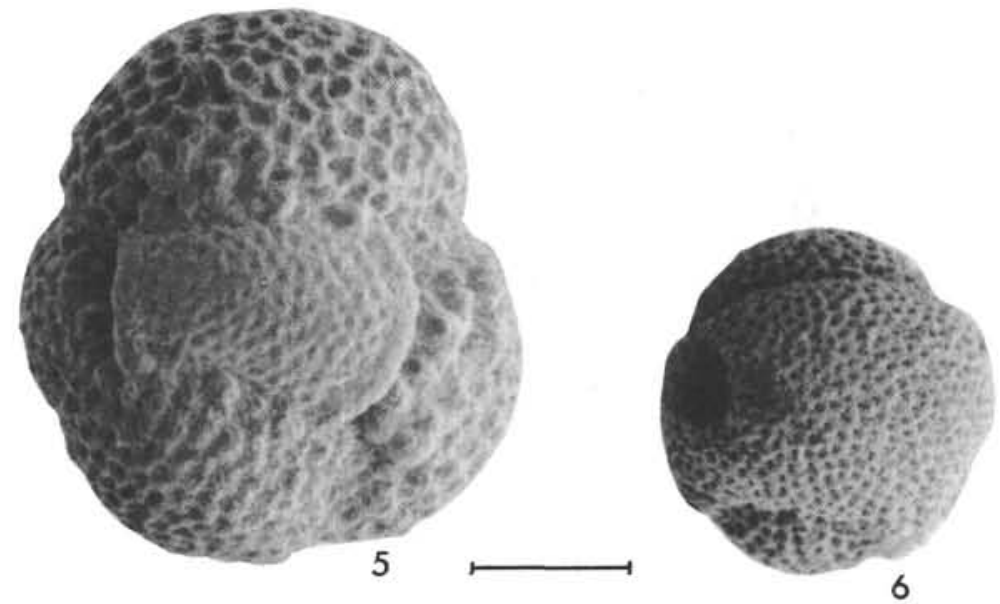
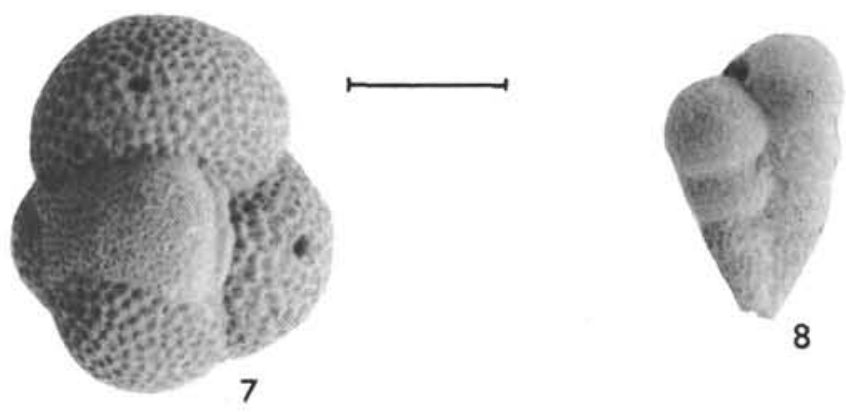

PLATE 4. Figure 1 Acarinina soldadoensis angulosa (Bolli), ventral view. Sample 220-15-6, 70-72 cm; Zone P.9. D = 0.39 mm. Aperture retouched. Figure 2 Acarinina soldadoensis soldadoensis (Brönnimann), ventral view. Sample 220-15-6, 70-72 cx; Zone P.9. $D=0.33 \mathrm{~mm}$. Aperture retouched. Figure 3 Cassigerinella chipolensis (Cushman and Ponton). Sample 219-15-5, 51-53 cm; Zone P.18-P.19. D = $0.13 \mathrm{~mm}$. Aperture retouched. Figure 4 Catapsydrax dissimilis ciperoensis (Blow and Banner), ventral view. Sample 223-28-1, $54-55 \mathrm{~cm}$; Zone P.22. D = 0.36 mm. Figure 5 Catapsydrax dissimilis dissimilis (Cushman and Bermúdez), ventral view. Core 223-29-4, 75-76 cm; Zone P.20-P.21. D = 0.39 mm. Figure 6 Catapsydrax globiformis (Blow and Banner), ventral view. Sample 219-17, CC; Zone P.15. D $=0.24 \mathrm{~mm}$. Figure 7 Catapsydrax perus (Todd), ventral view. Sample 219-15-1, 51-53 cm; Zone P.18-P.19. D $=0.52 \mathrm{~mm}$. Figure 8 Chiloguembelina cubensis (Palmer), lateral view. Sample 219-16-1, 48-50 cm; Zone P.18-P.19. D $=0.19 \mathrm{~mm}$. 

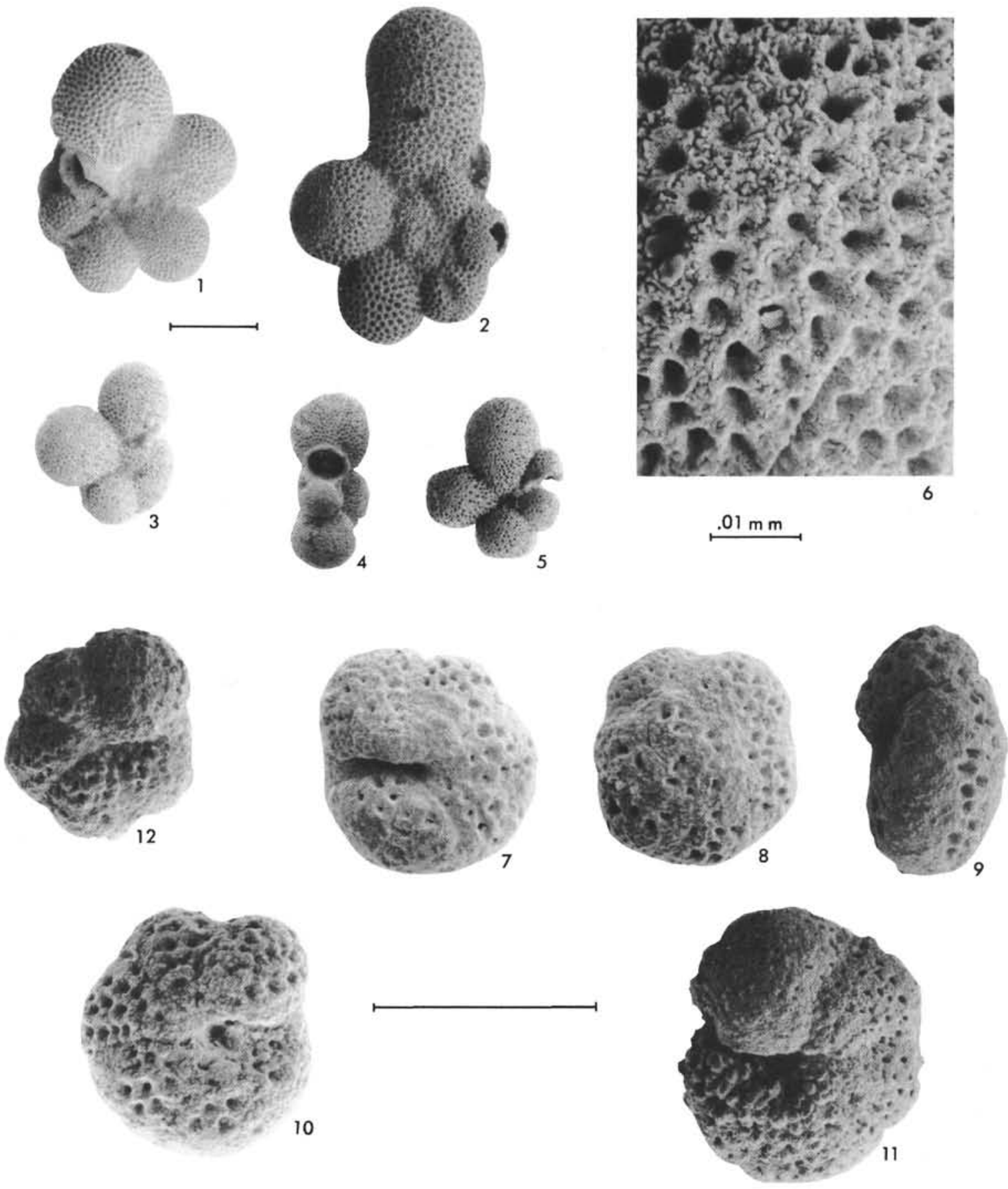

PLATE 5. Figures 1, 2 Clavatorella bermudezi (Bolli), both from Sample 219-13-1, 24-26 cm;Zone N.10. Figure 1 Ventral view. $D=0.60 \mathrm{~mm}$. The radial elongation of the final chamber is incompletely developed, but the aperture is typical. The similarity with Globorotaloides variabilis is evident in this specimen. Figure 2 Dorsal view. $D=0.42 \mathrm{~mm}$. Note the coarsely cancellate wall texture. Figures 3-6 Protentella prolixa Lipps. All are topotypes collected from upper Lusian (Middle Miocene) horizons in the Monterey Formation, Newport Bay, California, U.S.A. Figure 3 Dorsal view. $D=0.20$ mm. Figure 4 Apertural view. $D=0.22 \mathrm{~mm}$. Figure 5 Ventral view. $D=0.20 \mathrm{~mm}$. Figure 6 Detail of dorsal wall of final chamber, same specimen as Figure 3. Although pore pits are weakly developed, no cancellate texture or regular pattern of pore distribution are developed. Figures 7-12 Globanomalina laccadivensis, n. sp. All from Sample 219-18-2, 55-57 cm; Zone P.15. Figure 7 Holotype, ventral view. $D=0.12 \mathrm{~mm}$. Figure 8 Paratype, dorsal view. $D=0.11 \mathrm{~mm}$. Figure 9 Paratype, lateral (apertural) view. $D=0.12 \mathrm{~mm}$. Figure 10 Paratype, ventral view. $D=0.12 \mathrm{~mm}$. Figure 11 Transitional form from Globanomalina pseudoscitula, ventral view. $D=0.14 \mathrm{~mm}$. The periphery is angular on the final chamber and rounded on earlier ones. Figure 12 Paratype, ventral view. $D=0.11 \mathrm{~mm}$. 


\section{PLATE 6}
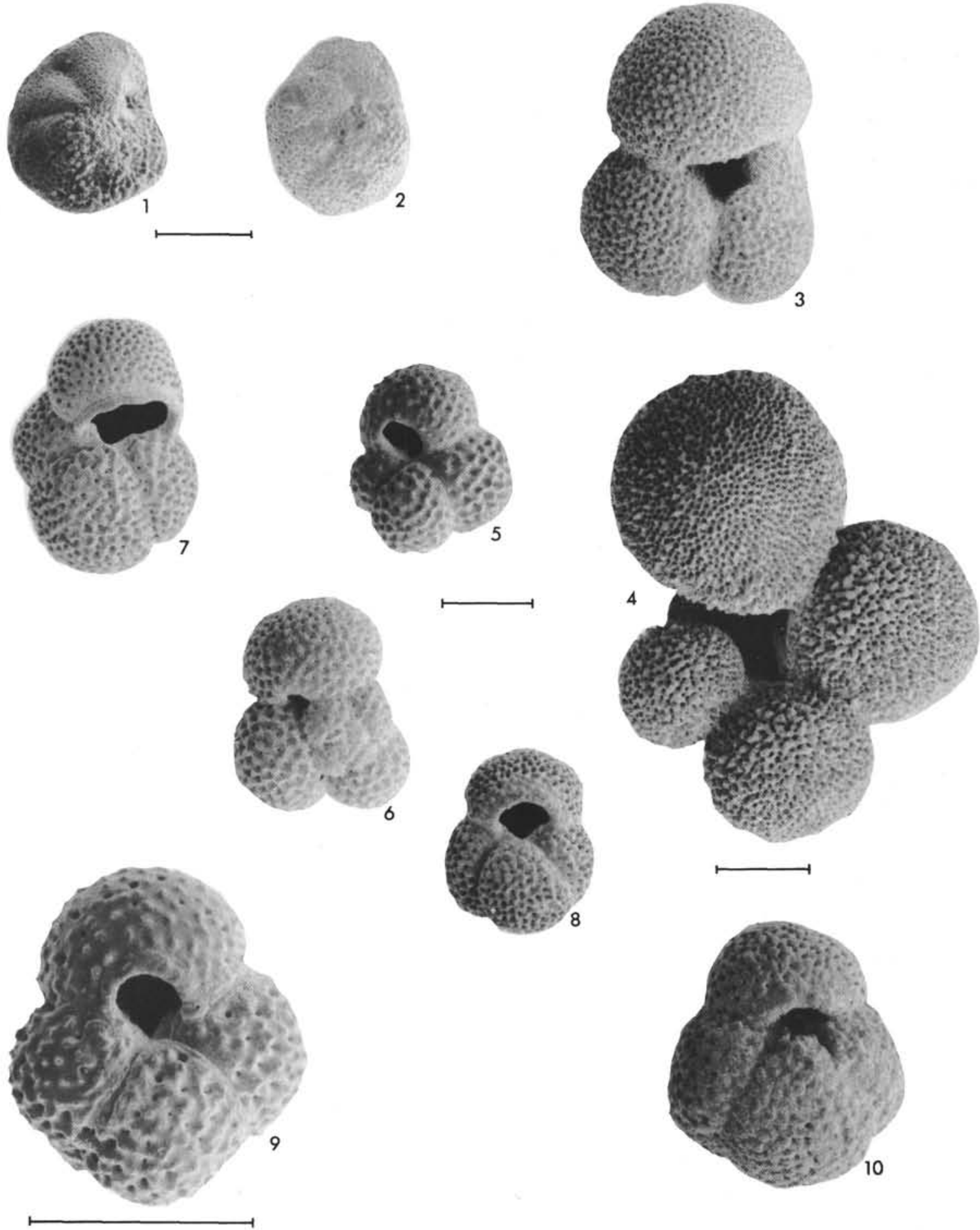

PLATE 6. All specimens except Figure 9 are illustrated at the same magnification. Figures 1, 2 Globanomalina pseudoscitula (Glaessner). Figure 1 Ventral view. Sample 219-18-5, 51-53 cm; Zone P.14. D = 0.23 mm. Figure 2 Doraal view. Sample 220-18-3, 138-140 cm; Zone P.8. D =0.22 mm. Figure 3 Globigerina bulloides d'Orbigny, ventral view. Sample 219-1-2, $70-72 \mathrm{~cm}$; Zone N.22. $D=0.35 \mathrm{~mm}$. Aperture retouched. Figure 4 Globigerina calida Parker, ventral view. Sample 219-1-2, $70-72 \mathrm{~cm}$; Zone N.22. $D=0.57 \mathrm{~mm}$. Figures 5, 6 "Globigerina" tenella (Parker), both from Sample 219-1-2, 70-72 cm; Zone N.22. Figure 5 Ventral view. $D=0.23 \mathrm{~mm}$. Figure 6 Dorsal view. $D=0.27 \mathrm{~mm}$. Figure 7 "Globigerina" nepenthes (Todd), ventral view. Sample 213-7-1, 131-133 cm; Zone N.18. D =0.31 mm. Figure 8 "Globigerina" rubescens decoraperta (Takayanagi and Saito), ventral view. Sample 219-7-5, 73-75 cm; Zone N.18. D=0.23 mm. Figure 9 "Globigerina" rubescens rubescens (Hofker), ventral view. Core 219-1-1, 110-112 cm; Zone N.23. D = 0.16 mm. Figure 10 "Globigerina" pseudodruryi (Brönnimann and Resig), ventral view. Sample 219-14-3, 46-48 cm; Zone N.7-N.8. D=0.33 mm. 
PLATE 7
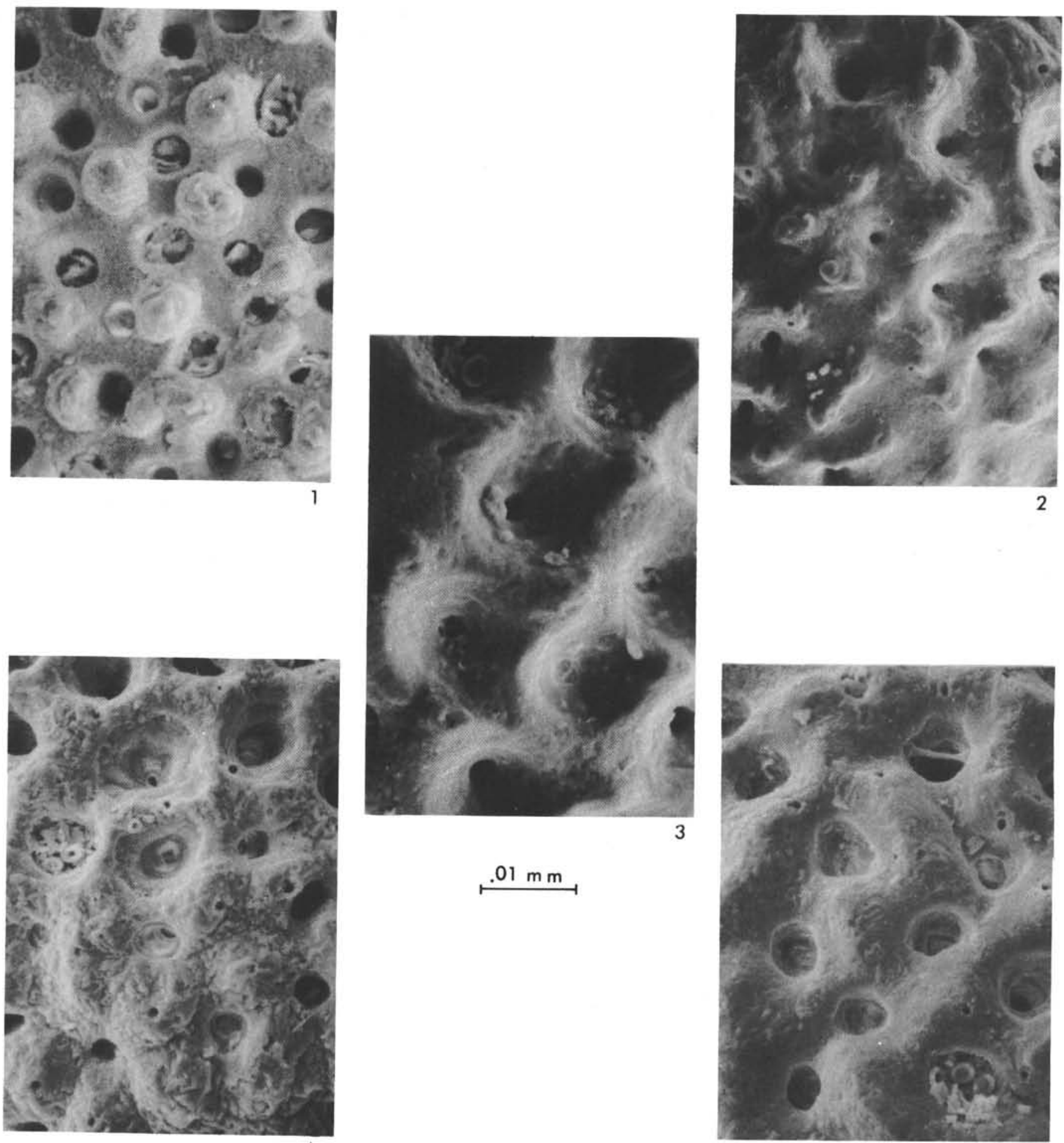

PLATE 7. All specimens are illustrated at the same magnification. Figure 1 Detail of ventral wall of final chamber of Globigerina bulloides. Same specimen as Plate 6, Figure 3. Figure 2 Detail of ventral wall of antepenultimate chamber of "Globigerina" rubescens rubescens. Same specimen as Plate 6, Figure 9. Figure 3 Detail of ventral wall of penultimate chamber, "Globigerina" tenella. Same specimen as Plate 6, Figure 5. Figure 4 Detail of ventral wall of antepenultimate chamber of "Globigerina" rubescens decoraperta. Same specimen as Plate 6, Figure 8. Figure 5 Detail of ventral wall of antepenultimate chamber of "Globigerina" nepenthes. Same specimen as Plate 6, Figure 7. 


\section{PLATE 8}
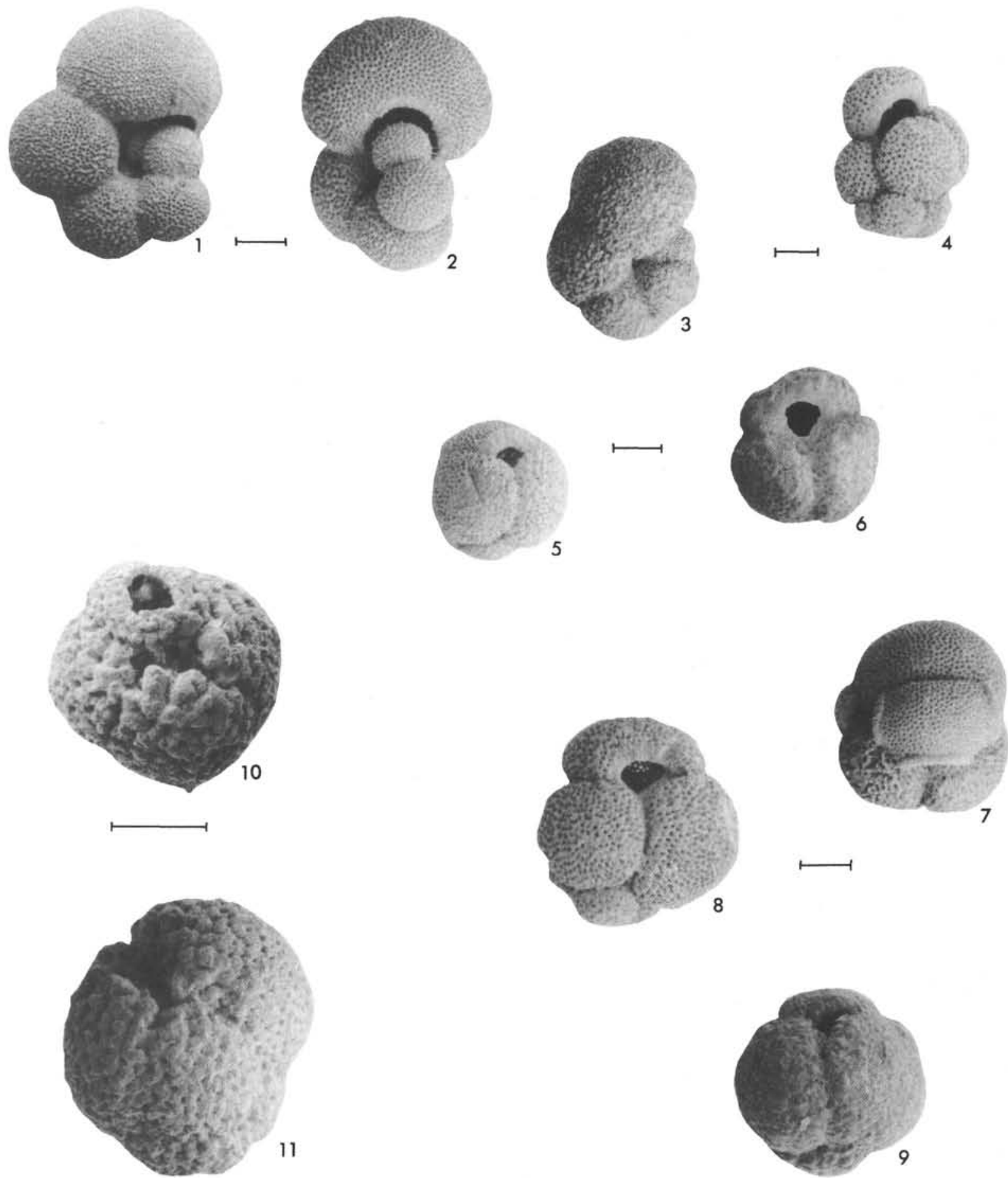

PLATE 8. All specimens except Figures 10 and 11 are illustrated at the same magnification. Figures 1, 2 Globigerinella siphonifera siphonifera (d'Orbigny). Both from Sample 219-1-1, 110-112 cm; Zone N.23. Figure 1 Side view. $D=0.60$ mm. Figure 2 Apertural view. $D=0.59 \mathrm{~mm}$. Figure 3 Globigerinella siphonifera involuta (Cushman), side view. Sample 219-12-5, $70-72 \mathrm{~cm}$; Zone N.17. $D=0.49 \mathrm{~mm}$. Figure 4 Globigerinatheka higginsi (Bolli). Sample 219-21-1, 51-53 cm; Zone P.10. Figure 5 Globigerinatheka mexicana mexicana (Cushman). Sample 219-19-5, $52-54 \mathrm{~cm}$; Zone P.14. D = 0.34 mm. Figure 6 Globigerinatheka index index (Finlay). Sample 220-12-5, 70-72 cm; Zone P.11. D = 0.37 mm. Aperture retouched. Figure 7 Globigerinatheka index tropicalis (Blow and Banner). Sample 219-18-5, 51-53 cm; Zone P.14. D = $0.46 \mathrm{~mm}$. Figure 8 Globigerinatheka subconglobata curryi Proto Decima and Bolli. Sample 219-19-6, 51-53 cm; Zone P.11. D = 0.50 mm. Figure 9 Globigerinatheka subconglobata subconglobata (Chalilov). Sample 220-12-1, 135-137 cm; Zone P.11. D = 0.44 mm. Figures 10,11 Globigerinatheka senni (Beckmann). Both from Sample 219-19-6, 51-53 cm; Zone P.11. Figure 10 Ventral view. $D=0.27 \mathrm{~mm}$. Figure 11 Lateral view. $D=0.34 \mathrm{~mm}$. 


\section{PLATE 9}
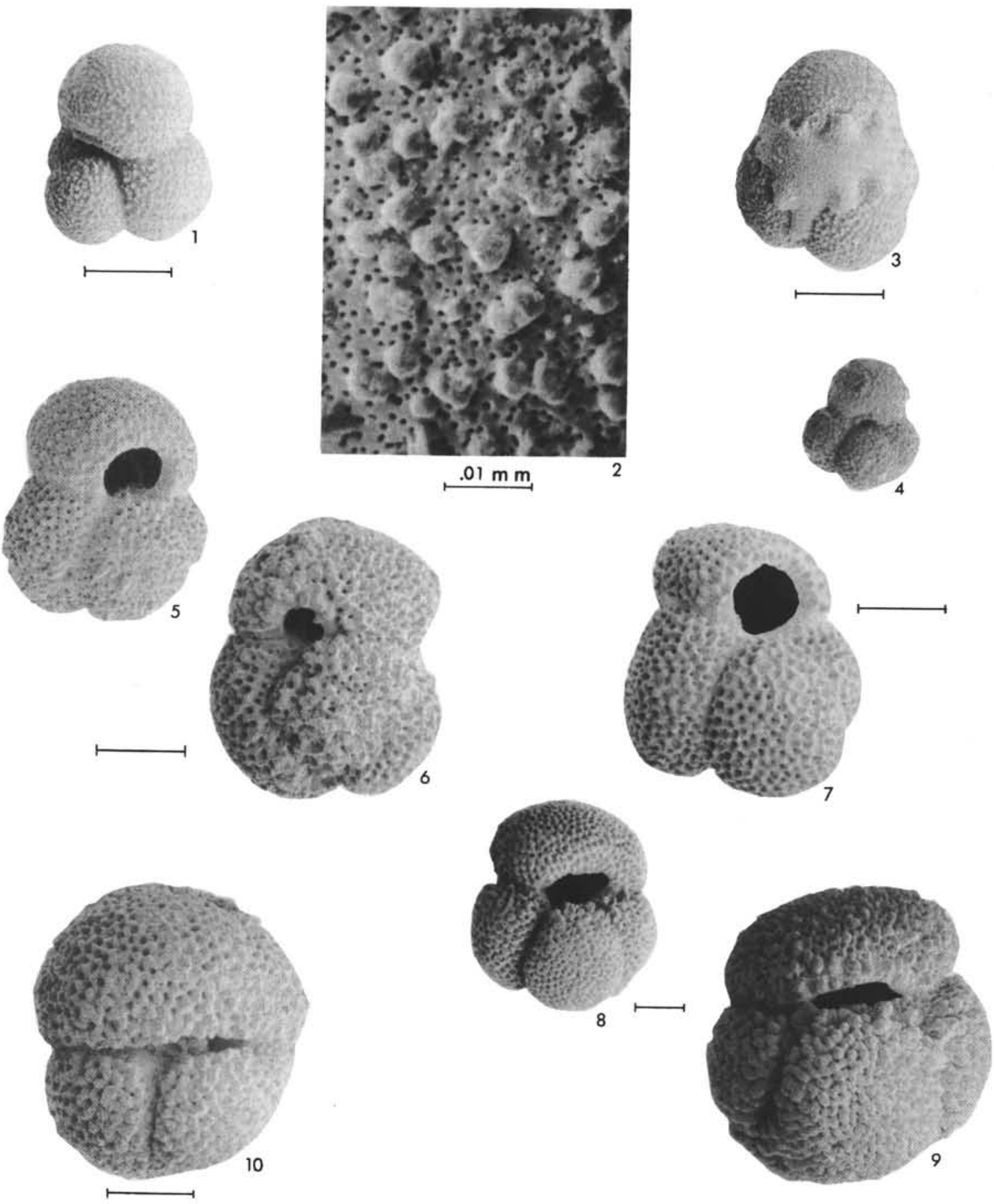

PLATE 9. Figures 1, 2 Globigerinita glutinata glutinata (Egger). Figure 1 Ventral view. Sample 219-1-2, 70-72 cm; Zone N.22. $D=0.27 \mathrm{~mm}$. Figure 2 Detail of ventral wall of final chamber. Same specimen as Figure 1. Figure 3 Globigerinita glutinata ambitacrena (Loeblich and Tappan), ventral view. Sample 219-1-2, 70-72 cm; Zone N.22. D=0.27 mm. Figure 4 Globigerinita boweni Brönnimann and Resig, ventral view. Sample 219-13, CC; Zone N.7-N.8. D = 0.17 mm. Figures 5, 6 Globigerinoides aff. altiaperturus Bolli. Both from Sample 219-14-4, 55-57 cm; Zone N.7-N.8. Figure 5 Ventral view. $D=$ $0.32 \mathrm{~mm}$. Figure 6 Dorsal view. $D=0.35 \mathrm{~mm}$. Figure 7 Globigerinoides obliquus extremus Bolli and Bermúdez, ventral view. Sample 219-6-4, $73-75 \mathrm{~cm}$; Zone N.18. $D=0.36 \mathrm{~mm}$. Aperture retouched. Figure 8 Globigerinoides conglobatus canimarensis Bermúdez, ventral view. Sample 219-6-4, $73.75 \mathrm{~cm}$; Zone N.18. $D=0.53 \mathrm{~mm}$. Aperture retouched. Figure 9 Globigerinoides conglobatus conglobatus (Brady), ventral view. Sample 219-1-4, 70-72 cm; Zone N.22. D=0.78 mm. Aperture retouched. Figure 10 Globigerinoides sicanus s.l. de Stefani, ventral view. Sample 219-14-4, $55-57 \mathrm{~cm}$; Zone N.7-N.8. $D=0.37 \mathrm{~mm}$. 


\section{PLATE 10}
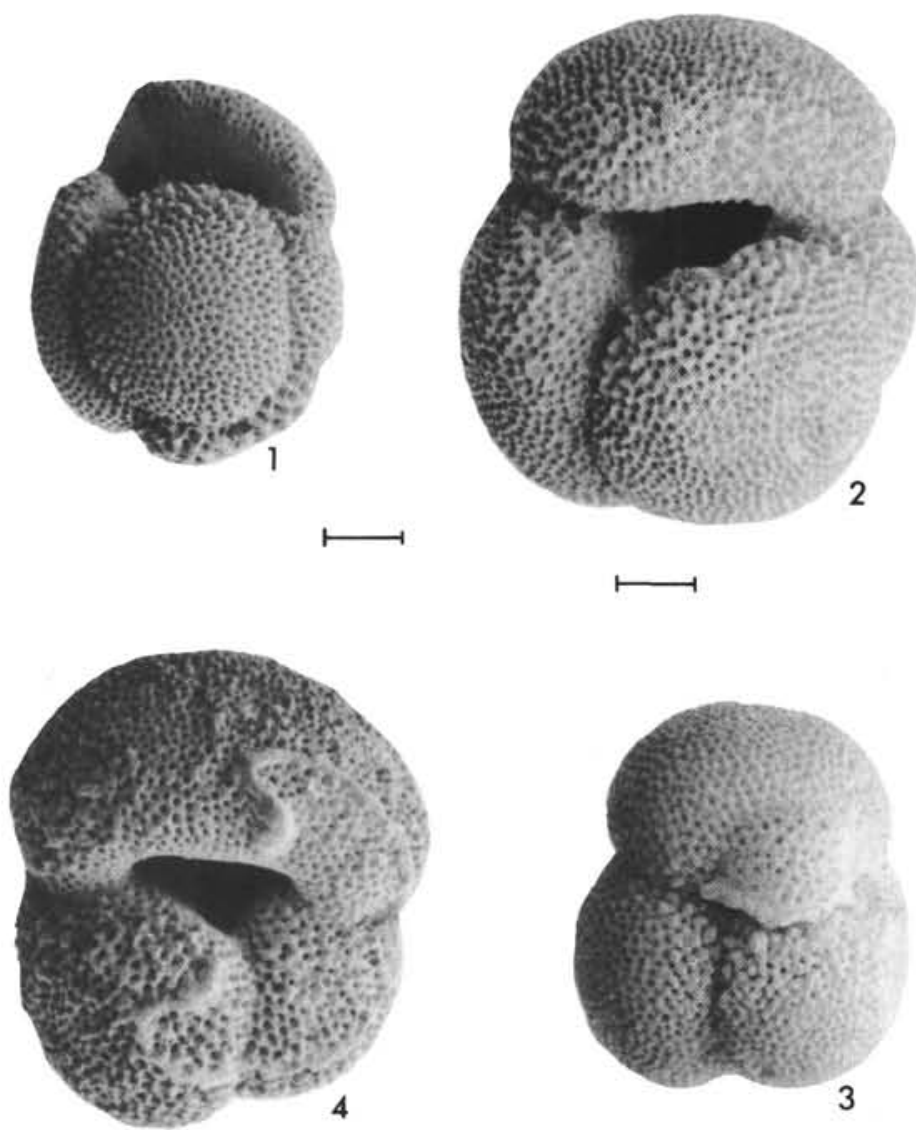

3
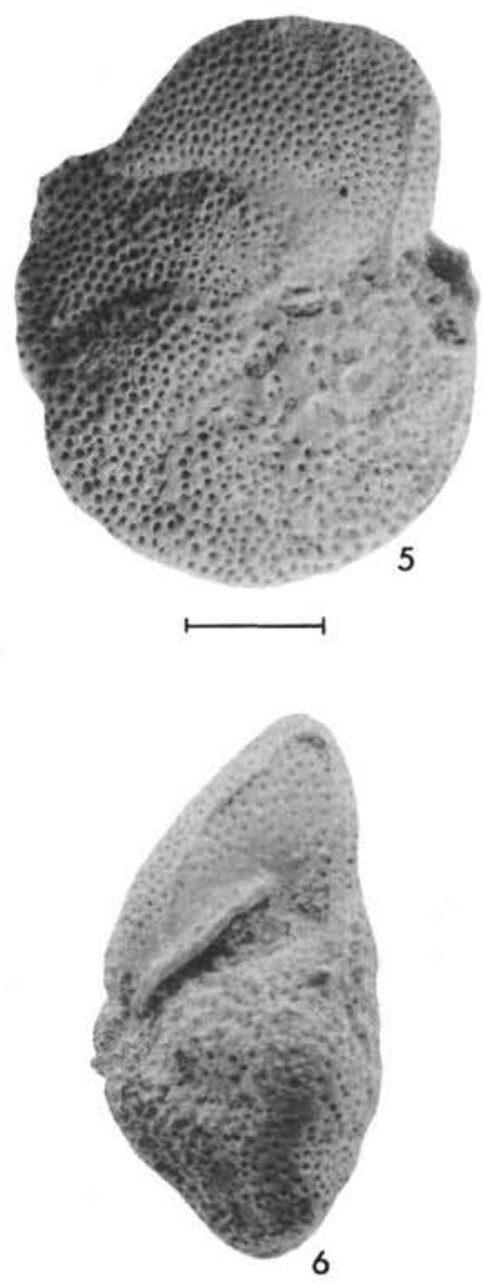
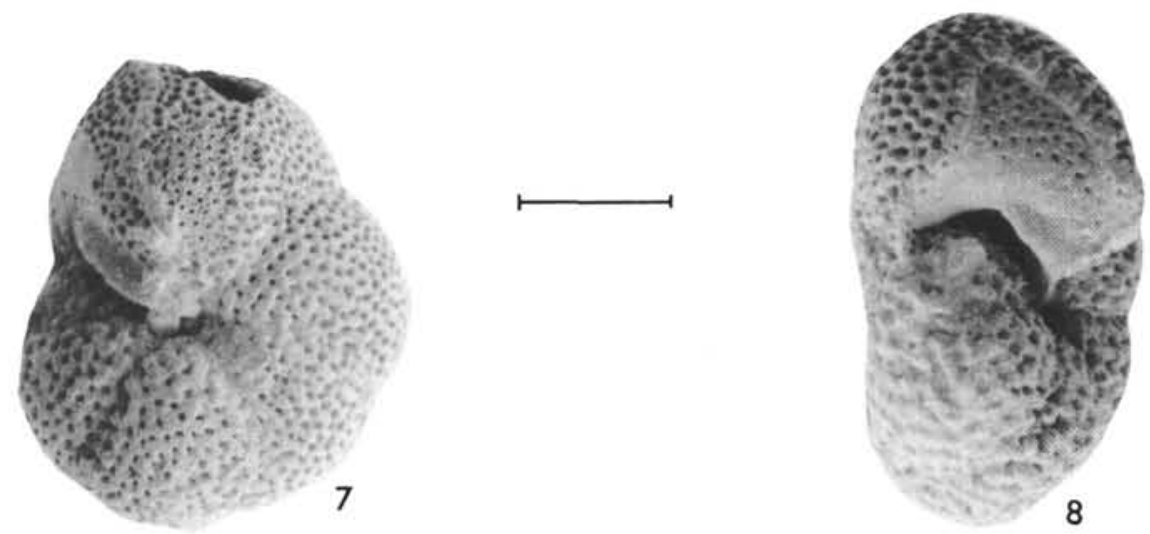

PLATE 10. Figure 1 Globoquadrina altispira altispira (Cushman and Jarvis). Sample 219-7-2, 73-75 cm; Zone N.18. D=0.54 mm. Figure 2 Globoquadrina conglomerata (Schwager), ventral view. Sample 219-1-2, 70-72 cm;Zone N.22. D=0.72 mm. Aperture retouched. Figure 3 Globoquadrina galavisi (Bermúdez), ventral view. Sample 219-18-1, 52-54 cm; Zone P.15. D = $0.55 \mathrm{~mm}$. Figure 4 Globoquadrina tripartita tapuriensis (Blow and Banner), ventral view. Sample 219-15-1, 51-53 cm;Zone P.18-P.19. $D=0.66 \mathrm{~mm}$. Figures 5, 6 Globorotalia (Fohsella) peripheroacuta Blow and Banner. Both from Sample 219-13-1, $24-26 \mathrm{~cm}$; Zone N.10. Figure 5 Dorsal view. $D=0.41 \mathrm{~mm}$. Figure 6 Apertural view. $D=0.38 \mathrm{~mm}$. Figures 7,8 Globorotalia (Fohsella) peripheroronda Blow and Banner. Both from Sample 219-14-3, 46 to $48 \mathrm{~cm}$; Zone N.7-N.8. Figure 7 Ventral view. $D=0.34 \mathrm{~mm}$. Figure 8 Apertural view. $D=0.36 \mathrm{~mm}$. 

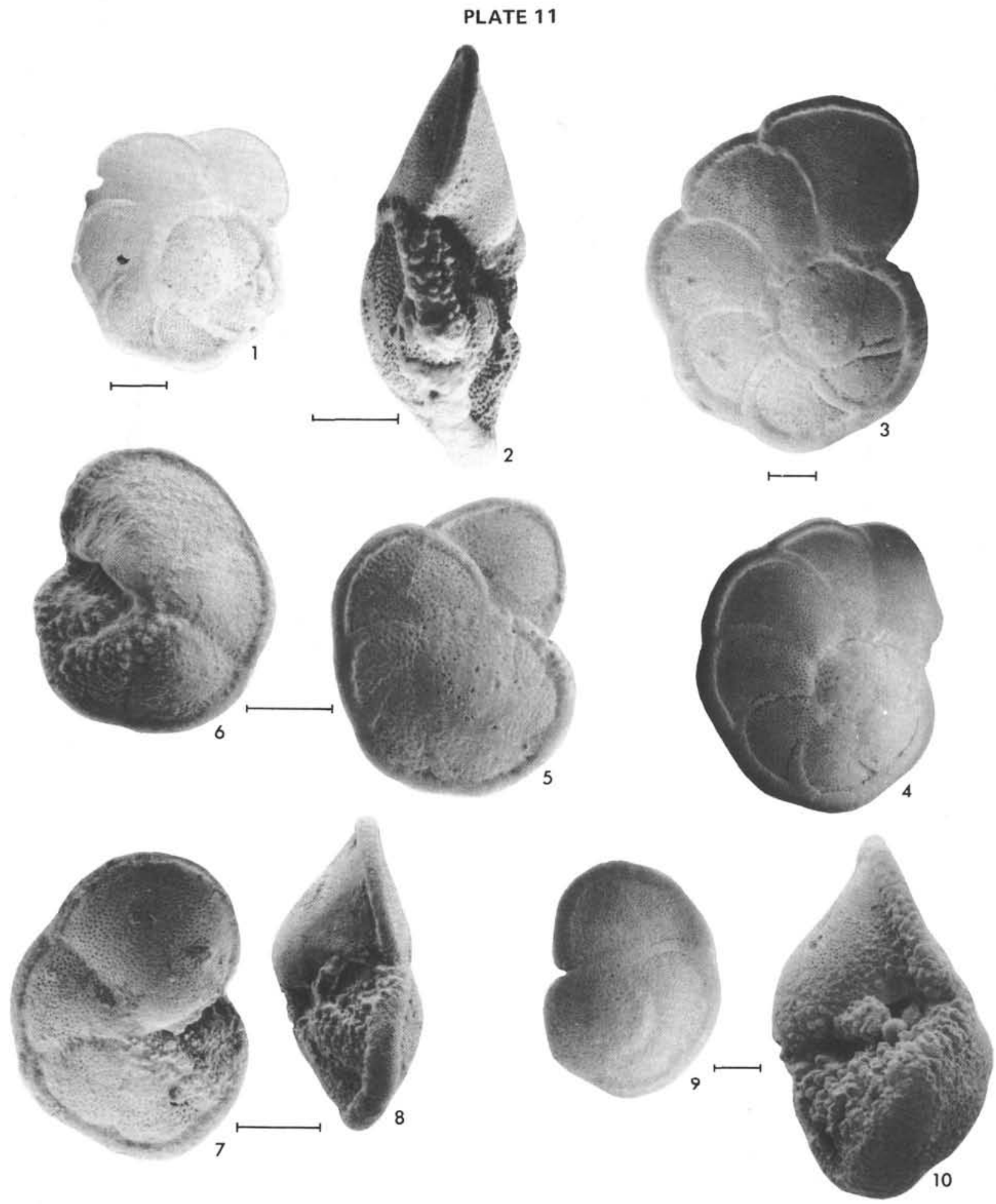

PLATE 11. Figures 1-4. Globorotalia (Globorotalia) limbata (d’Orbigny). Figure 1 Dorsal view. Sample 219-9-5, 70-72 cm; Zone N.17. $D=0.57 \mathrm{~mm}$. Figure 2 Apertural view; same specimen as Figure 1. Figure 3 Seven-chambered form, transitional to Globorotalia (G.) multicamerata. Sample 219-7-2, 73-75 cm; Zone N.18. $D=0.93 \mathrm{~mm}$. Figure 4 Seven and one-half chambered form, transitional to Globorotalia (G.) multicamerata. Sample 219-5, CC; Zone N.19-N.20.D = 0.77 mm. Figures 5, 6 Globorotalia (Globorotalia) merotumida Blow and Banner. Both from Sample 219-8-5, 70-72 cm; Zone N.18. Figure 5 Ventral view. $D=0.38 \mathrm{~mm}$. Figure 6 Dorsal view. $D=0.39 \mathrm{~mm}$. Figures 7,8 Globorotalia (Globorotalia) tumida plesiotumida Blow and Banner. Both from Sample 219-11-6, 70-72 cm; Zone N.17. Figure 7 Ventral view. $D=0.42 \mathrm{~mm}$. Figure 8 Apertural view. $D=0.40 \mathrm{~mm}$. Figures 9,10 Globorotalia (Globorotalia) tumida tumida (Brady). Both from Sample $219-1-4,70-72 \mathrm{~cm}$; Zone N.22. Figure 9 Dorsal view. $D=0.61 \mathrm{~mm}$. Figure 10 Apertural view. $D=0.91 \mathrm{~mm}$. 
PLATE 12
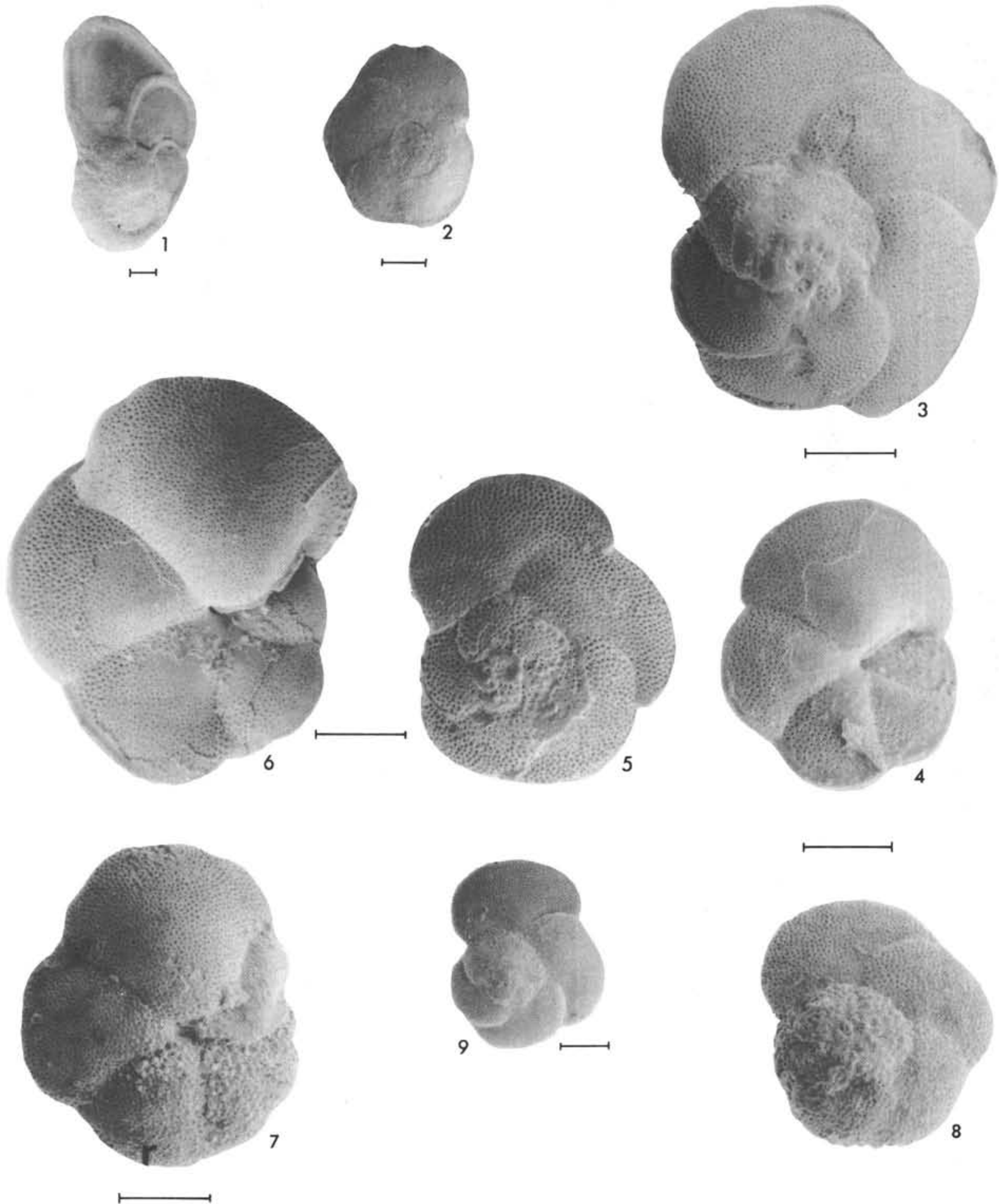

PLATE 12. Figure 1 Globorotalia (Globorotalia) tumida subsp. 1, dorsal view (slightly oblique). Sample 219-6-4, 73-75 cm; Zone N. 18. D = $1.19 \mathrm{~mm}$. Figure 2 Globorotalia (Globorotalia) praemenardii Cushman and Stainforth, dorsal view. Sample 219-13-1, 24-26 cm; Zone N.10. D = $0.44 \mathrm{~mm}$. Figures 3, 4 Globorotalia (Hirsutella) margaritae Bolli and Bermúdez. Both from Sample 219-6-4, 73-75 cm; Zone N.18. Figure 3 Dorsal view. $D=0.54 \mathrm{~mm}$. Figure 4 Ventral view. $D=0.35 \mathrm{~mm}$. Figures 5, 6 Globorotalia (Hirsutella) hirsuta praehirsuta Blow. Both from Sample 219-7-2, 73-75 cm; Zone N.18. Figure 5 Dorsal view. $D=0.40 \mathrm{~mm}$. Figure 6 Ventral view. $D=0.50 \mathrm{~mm}$. Figures 7,8 Globorotalia (Hirsutella) scitula praescitula Blow. Both from Sample 219-13-3, $47-49 \mathrm{~cm}$; Zone N.7-N.8. Figure 7 Ventral view. $D$ 0.39 mm. Figure 8 Dorsal view. $D=$ $0.32 \mathrm{~mm}$. Figure 9: Globorotalia (Hirsutella) theyeri, n. sp., dorsal view of small paratype. Sample 219-1-1, 110-112 cm; Zone N.23. $D=0.46 \mathrm{~mm}$. 


\section{PLATE 13}
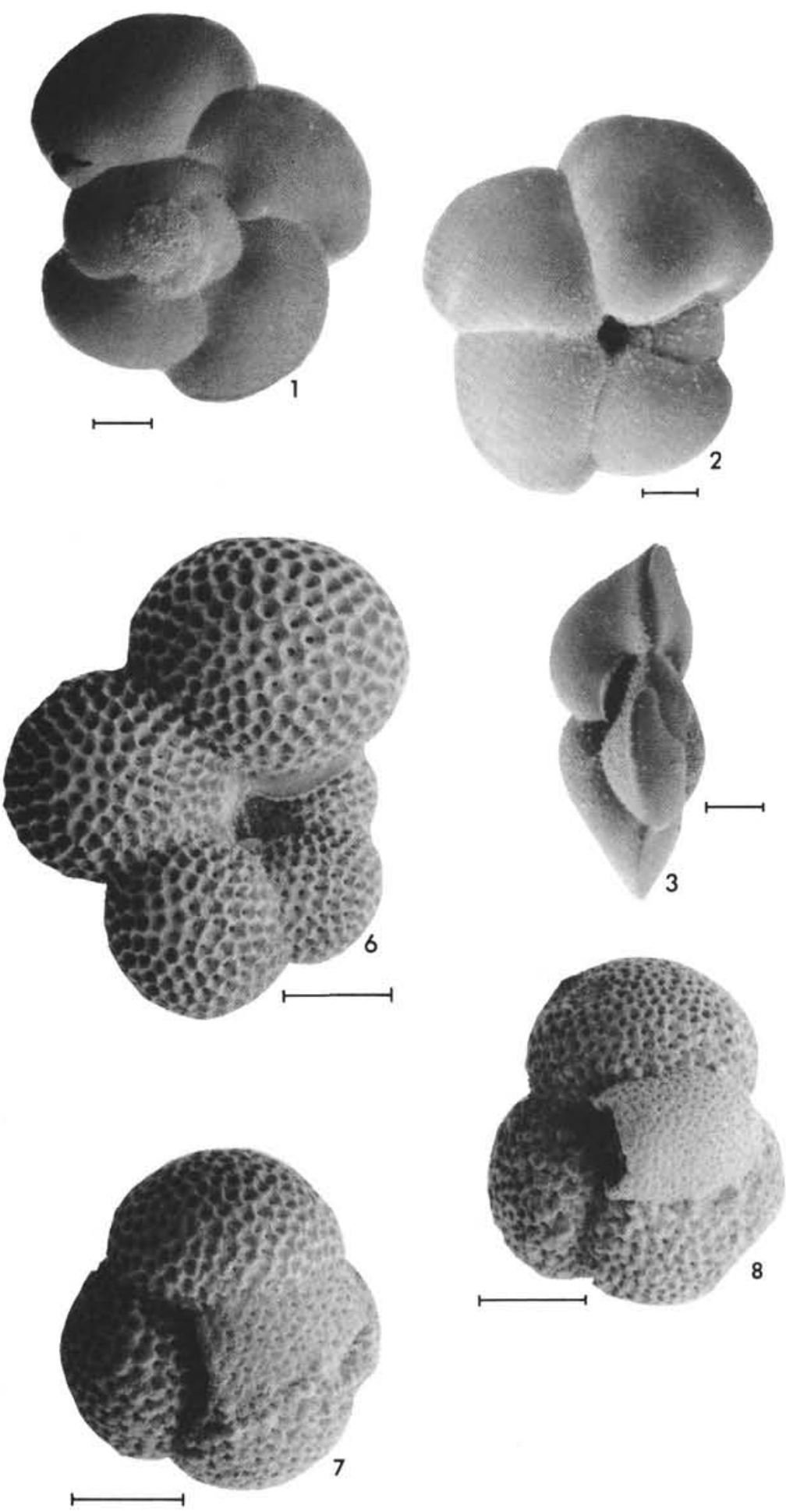
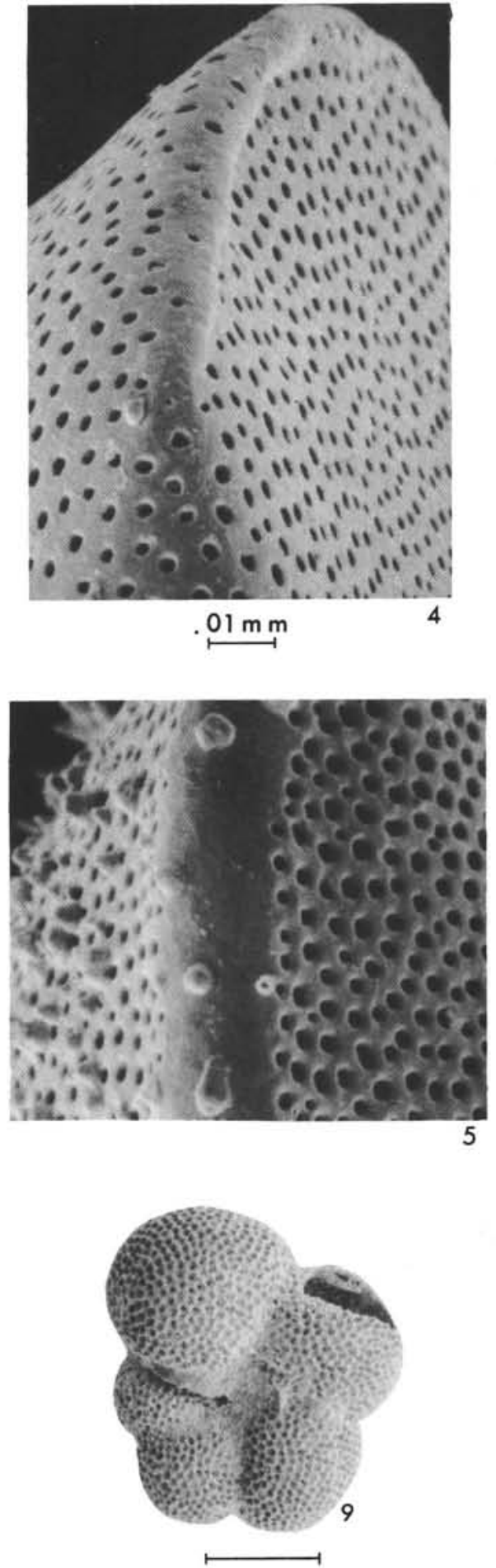

PLATE 13. Figures 1-5 Globorotalia (Hirsutella) theyeri, n. sp. All from Sample 219-1-1, 110-112 cm; Zone N.23. Figure 1 Holotype, dorsal view. $D=0.79 \mathrm{~mm}$. Figure 2 Holotype, ventral view. Figure 3 Paratype, apertural view. $D=0.73 \mathrm{~mm}$. Figure 4 Detail of periphery of final chamber, same specimen as Figure 3. Figure 5 Detail of periphery of first full chamber in final whorl, same specimen as Figure 3. Figure 6 Globorotaloides hexagonus (Natland), ventral view. Sample 219-1-2, $70-72 \mathrm{~cm}$.; Zone N.22. $D=0.48 \mathrm{~mm}$. Figure 7 Globorotaloides suteri Bolli, ventral view. Sample 219-15-4, $51-53 \mathrm{~cm} ;$ Zone P.18-P.19. $D=0.35 \mathrm{~mm}$. Figure 8 Globorotaloides turgida (Finlay), ventral view. Sample 220-12-3, 70-72 cm; Zone P.11. D $=0.35 \mathrm{~mm}$. Figure 9 Globorotaloides variabilis Bolli, ventral view. Sample 219-8-5, 70-72 cm; Zone N.18.D =0.33 mm. This specimen should be compared with Clavatorella bermudezi, Plate 5, Figure 1. 


\section{PLATE 14}
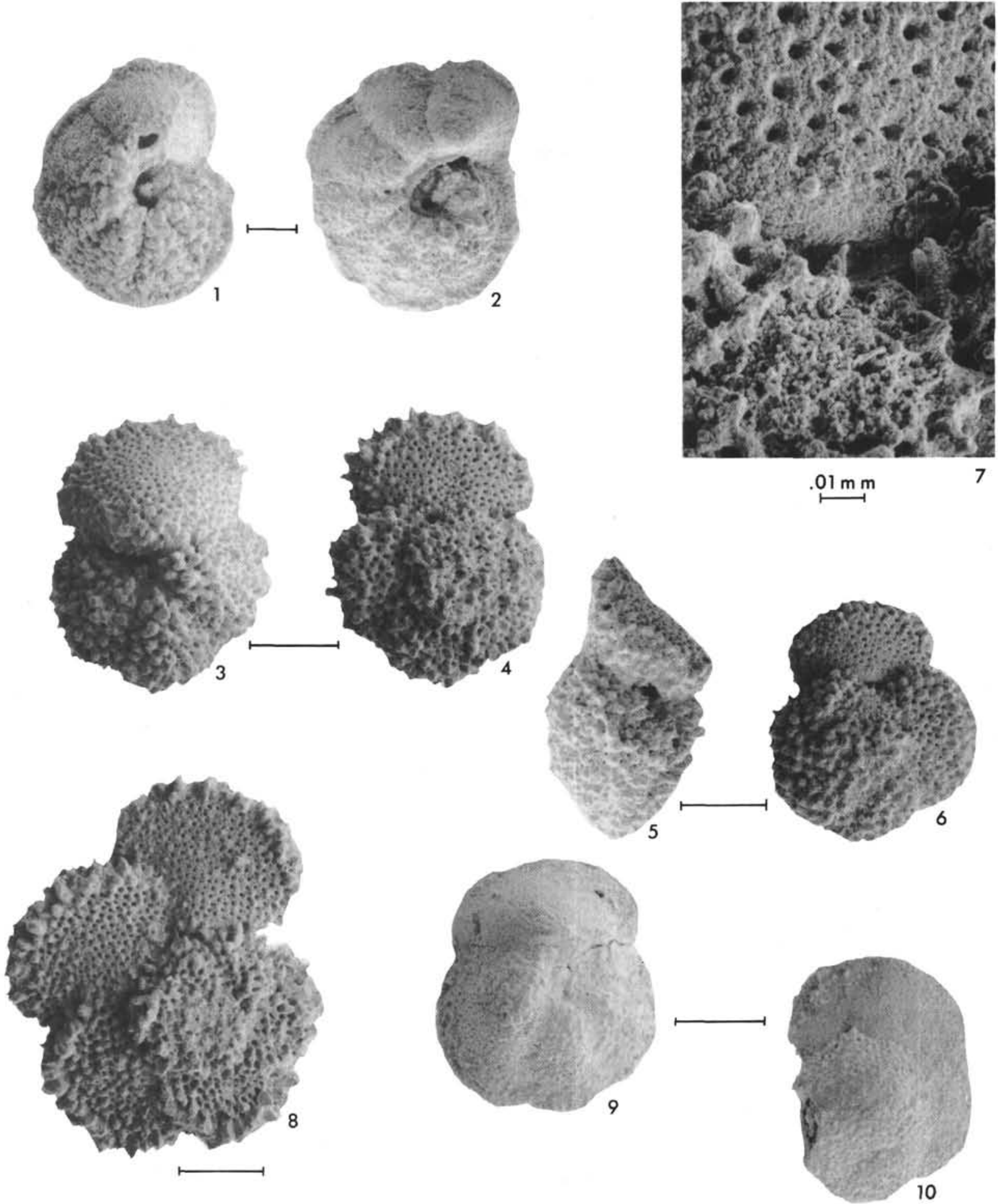

PLATE 14. Figure 1 Morozovella aragonensis aragonensis (Nuttall), ventral view. Sample 219-20-4, 52-54 cm; Zone P.11.D = $0.61 \mathrm{~mm}$. Figure 2 Morozovella aragonensis caucasica (Glaessner), ventral view. Sample 220-18-3, 138-140 cm; Zone P.8.D = $0.66 \mathrm{~mm}$. Figures 3-8 Morozovella bandyi, n. sp. All from Sample 219-19-6, 51-53 cm.; Zone P. 11. Figure 3 Holotype, ventral view. $D=0.35 \mathrm{~mm}$. Figure 4 Holotype, dorsal view. Figure 5 Holotype, apertural view. Figure 6 Paratype, dorsal view. $D=0.30 \mathrm{~mm}$. Figure 7 Detail of dorsal accessory aperture, same specimen as Figure 6 . The imperforate apertural rim is clearly visible. Figure 8 Large, full-chambered paratype, dorsal view. $D=0.49 \mathrm{~mm}$. Figures 9, 10 Morozovella cf. woodi (El-Naggar). Both from Sample 219A-12-3, $82-84 \mathrm{~cm}$; Zone P.4. Figure 9 Ventral view. $D=0.33 \mathrm{~mm}$. Figure 10. Dorsal view. $D=0.32 \mathrm{~mm}$. 

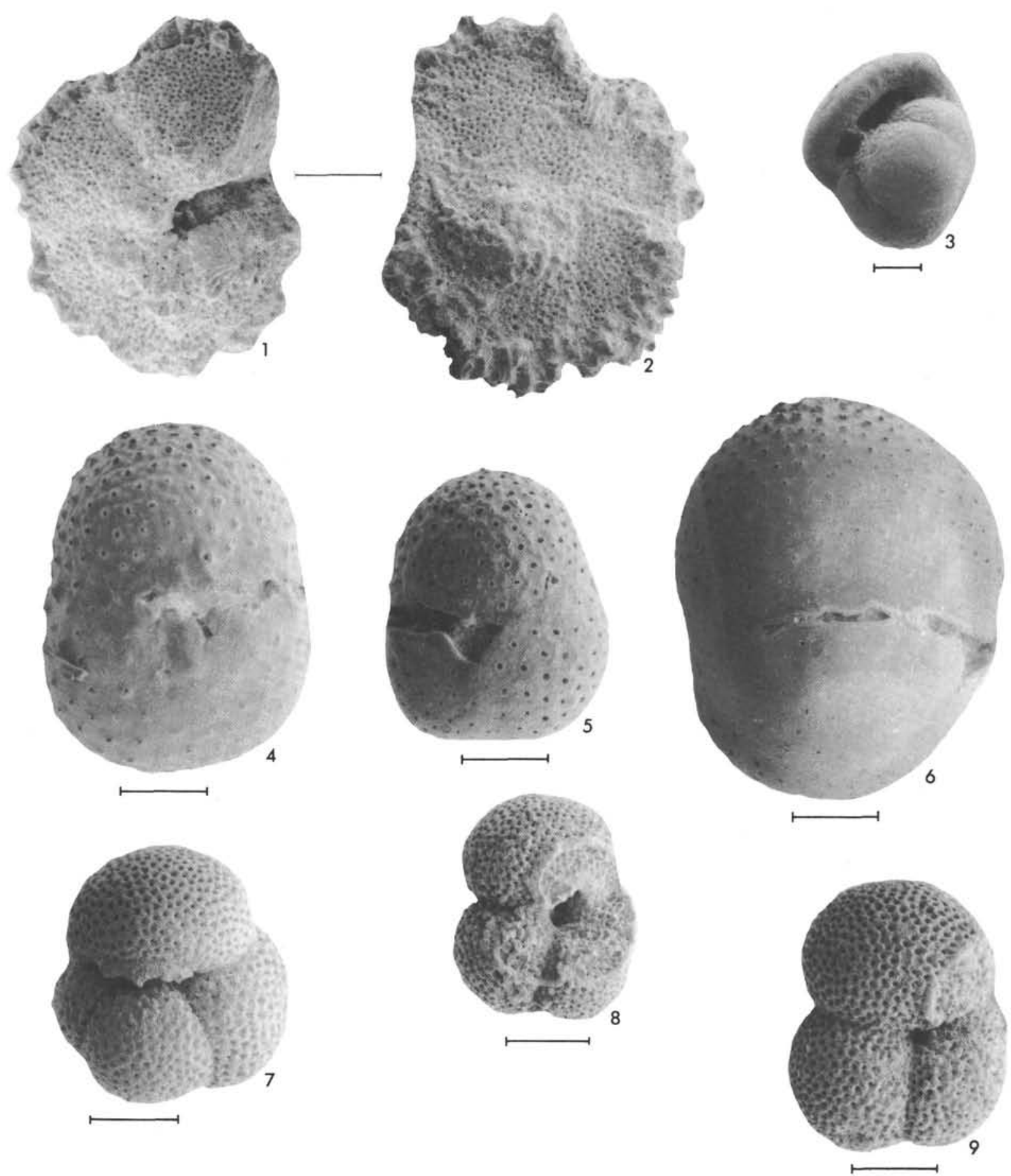

PLATE 15. All specimens except Figure 3 are illustrated at the same magnification. Figures 1,2 Morozovella coronata Blow. Figure 1 Ventral view. Sample 220-12-1, 135-137 cm; Zone P.11. D =0.47 mm. Figure 2 Dorsal view. Sample 220-12-4, $70-72 \mathrm{~cm}$; Zone P.11. $D=0.50 \mathrm{~mm}$. Figure 3 Pulleniatina praespectabilis Brönnimann and Resig, apertural view. Sample 219-8:6, 70-72 cm; Zone N.17. D = 0.52 mm. Figure 4 Sphaeroidinellopsis sphaeroides Lamb, ventral view. Sample 219-6-4, $73-75 \mathrm{~cm}$; Zone N.18. D = $0.43 \mathrm{~mm}$. Figure 5 Sphaeroidinellopsis subdehiscens (Blow), ventral view. Sample 219-6-4, 73-75 cm; Zone N.18. $D=0.34 \mathrm{~mm}$. In contrast to Figure 4, the chambers are relatively more distinct and a flange is developed only on the lower apertural margin. Figure 6 Sphaeroidinellopsis paenedehiscens Blow, lateral (apertural) view. Sample 219-6-2, $73-75 \mathrm{~cm}$; Zone N.19-N.20. $D=0.50 \mathrm{~mm}$. The peripheral extension of the aperture, discontinuous in the illustrated specimen, is clearly visible. Figure 7 Subbotina angiporoides (Hornibrook), ventral view. Sample 219-17-1, 134-136 cm; Zone P.17.D = $0.34 \mathrm{~mm}$. Figure 8 Subbotina eocaena (Gümbel), ventral view. Sample 220-16-2, 68-70 cm; Zone P.8. D=0.29 mm. Figure 9 Subbotina eocaenica (Terquem), ventral view. Sample 220-12-1, 135-137 cm; Zone P.11. D=0.35 mm. 
PLATE 16
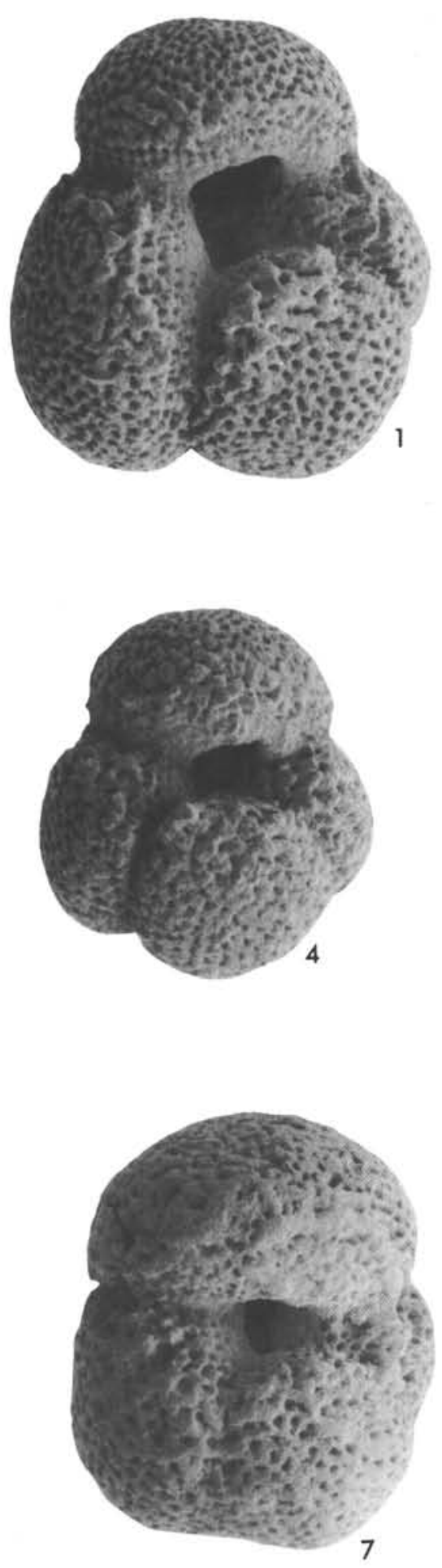
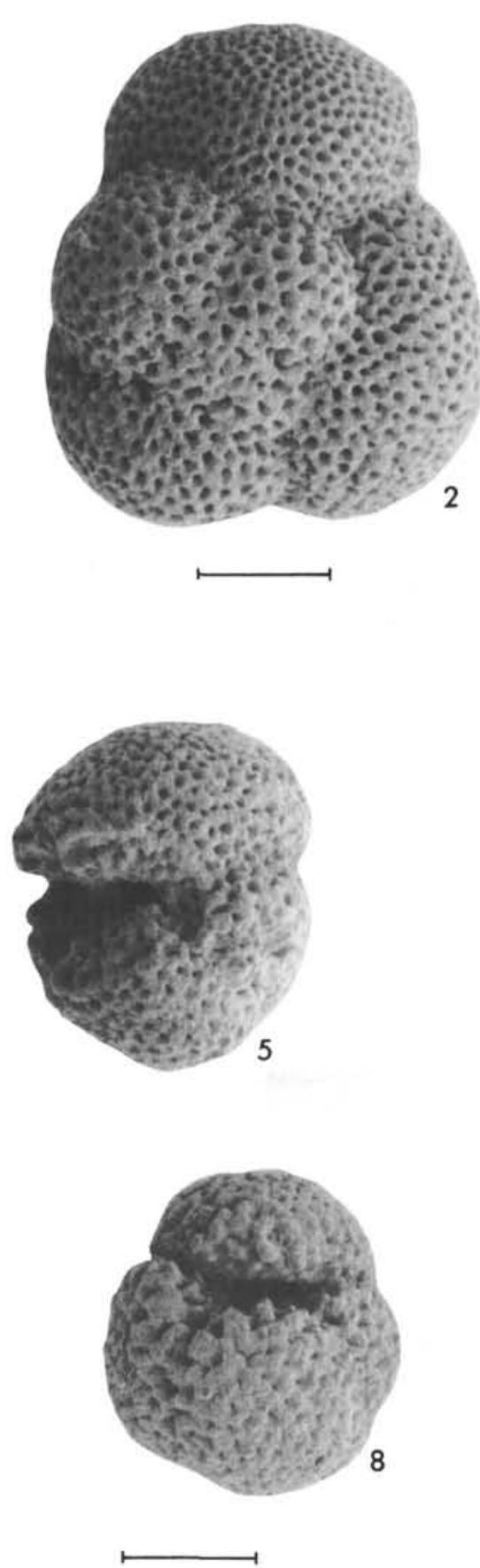
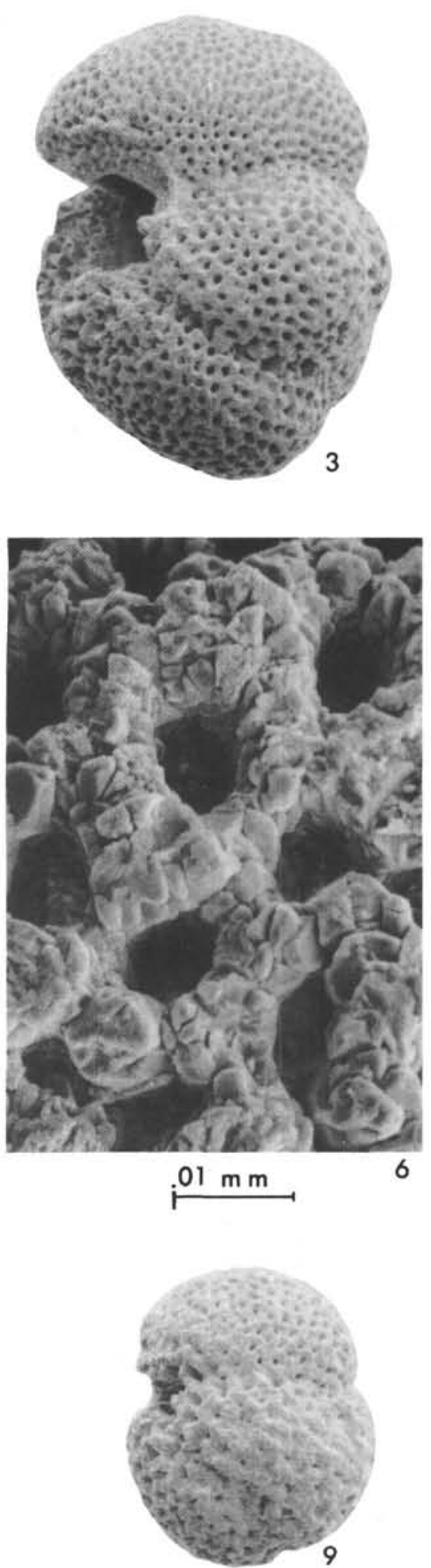

PLATE 16. All specimens except Figure 6 are illustrated at the same magnification. Figures 1-9 Subbotina kiersteadae, n. sp. All from Core 219-19-6, 51-53 cm; Zone P.11. Figure 1 Holotype, ventral view. $D=0.43 \mathrm{~mm}$. Figure 2 Holotype, dorsal view. Figure 3 Holotype, lateral view. Figure 4 Paratype, ventral view. $D=0.35 \mathrm{~mm}$. Aperture slightly retouched. Figure 5 Small paratype, lateral (apertural) view. $D=0.29 \mathrm{~mm}$. Figure 6 Detail of lateral wall of final chamber, same specimen as Figure 5. Figure 7 Paratype, ventral view. $D=0.41 \mathrm{~mm}$. Note the rudimentary development of a thickened crust, obscuring the pores. Aperture retouched. Figure 8 Form transitional to Globigerinatheka senni, ventral view. $D=0.27 \mathrm{~mm}$. Figure 9 Lateral view, same specimen as Figure 8. 

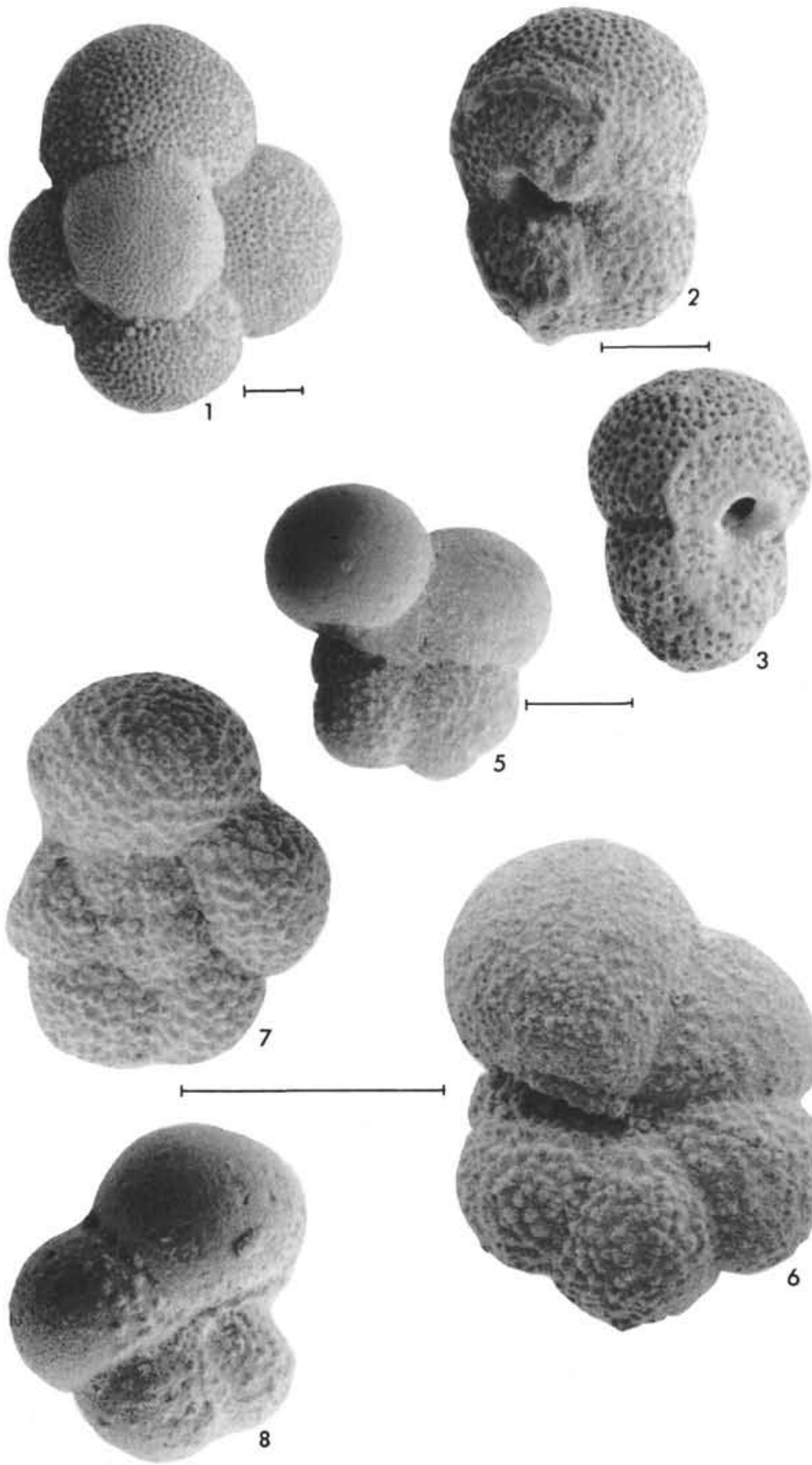
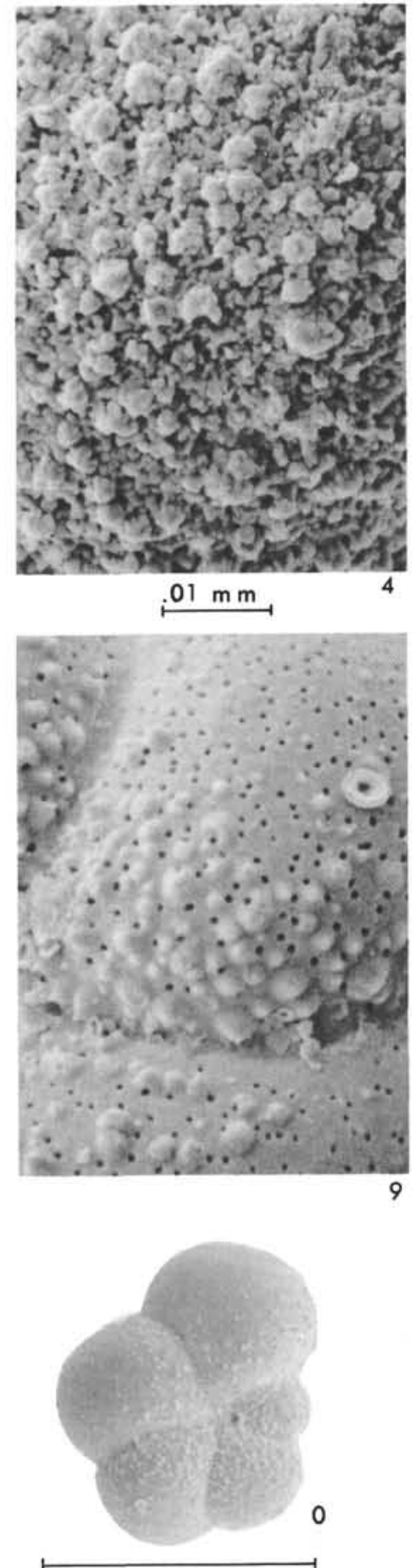

PLATE 17. Figure 1 Subbotina winkleri (Bermúdez), ventral view. Sample 219-18-1, $52-54 \mathrm{~cm} ; Z$ one P.15. D = 0.76 mm. Figures 2, 3 Subbotina patagonica (Todd). Both from Sample 220-13-1, 70-72 cm; Zone P.10. Figure 2 Ventral view. D= $0.33 \mathrm{~mm}$. Figure 3 Lateral (apertural) view. $D=0.31 \mathrm{~mm}$. Figures 4, 6, 7 Tenuitella gemma (Jenkins). Figure 4 Detail of ventral wall of final chamber, same specimen as Figure 6. Minute perforations are visible between the crystallites. Figure 6 Ventral view. Sample 219-15-2, 51-53 cm; Zone P.18-P.19. D = 0.19 mm. Figure 7 Dorsal view. Sample 219-15-4, 51-53 $\mathrm{cm}$; Zone P.18-P.19. $D=0.16 \mathrm{~mm}$. Figure 5 Tenuitella sp. 1, ventral view. Sample 219-13-1, 24-26 cm;Zone N.10. D=0.33 mm. Figure 8 Tenuitella clemenciae (Bermudez), ventral view. Sample 219-13-1, 24-26 cm; Zone N.10. D = 0.14 mm. Figures 9, 10 Tenuitella anfracta (Parker). Figure 9 Detail of ventral wall of antepenultimate chamber, same specimen as Figure 10. This wall texture should be compared with that of Globigerinita glutinata glutinata (Plate 9, Figure 2). Figure 10 Ventral view. Sample 219-1-4, 70-72 cm; Zone N.22. $D=0.12 \mathrm{~mm}$. 


\section{PLATE 18}
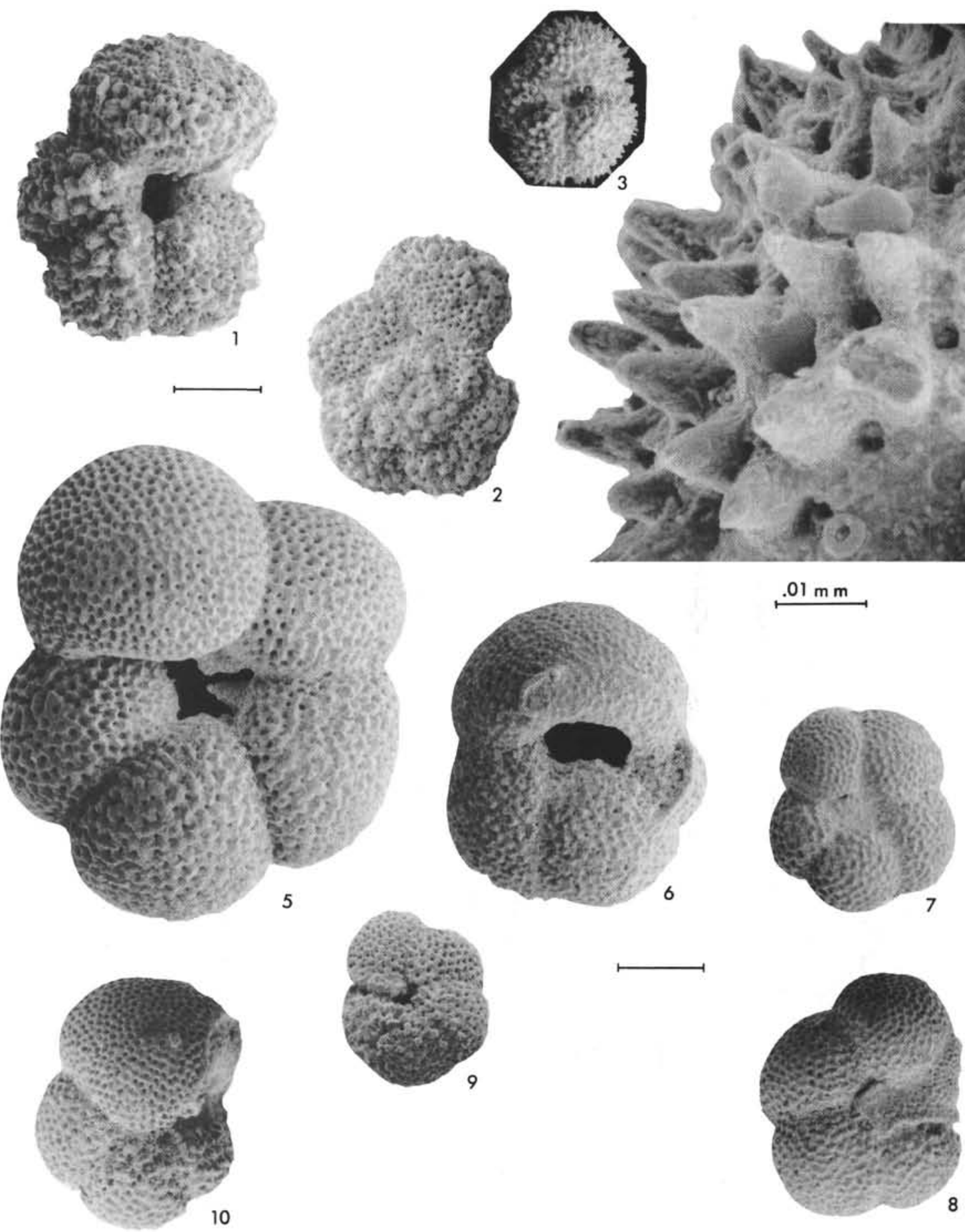

PLATE 18. All specimens are illustrated at the same magnification except Figure 4. Figures 1, 2 Truncorotaloides pseudodubius (Bandy). Both from Sample 219-19-6, $51-53 \mathrm{~cm}$; Zone P.11. Figure 1 Ventral view. $D=0.40 \mathrm{~mm}$. Aperture slightly retouched. Figure 2 Dorsal view. $D=0.35 \mathrm{~mm}$. Figures 3,4 Truncorotaloides collacteus (Finlay). Figure 3 Ventral view. Sample 223-32,CC; Zone P.12. $D=0.21 \mathrm{~mm}$. Figure 4 Detail of the wall of the penultimate chamber, same specimen as Figure 3. Figure 5 Turborotalia (Neogloboquadrina) dutertrei (D'Orbigny), ventral view. Sample 219-1-2, 70-72 cm; Zone N.22. $D=0.57 \mathrm{~mm}$. Aperture retouched. Figure 6 Turborotalia (Turborotalia) ampliapertura (Bolli), ventral view. Sample 219-16-4, 52-54 cm; Zone P.18-P.19. D = 0.39 mm. Aperture retouched. Figure 7 Turborotalia (Turborotalia) acostaensis acostaensis (Blow), ventral view. Sample 219-12-5, 70-72 cm; Zone N.17. D=0.27 mm Figure 8 Turborotalia (Turborotalia) acostaensis tegillata Brönnimann and Resig, ventral view. Sample 219-12-5, 70-72 cm; Zone N.17. D=0.33 mm. Figure 9 Turborotalia (Turborotalia) birnageae (Blow), ventral view. Sample 219-14-1, 105-107 cm; Zone N.7-N.8. D = 0.24 mm. Figure 10 Turborotalia (Turborotalia) continuosa (Blow), ventral view. Sample 219-12, CC; Zone N.17. D=0.34 mm. 


\section{PLATE 19}
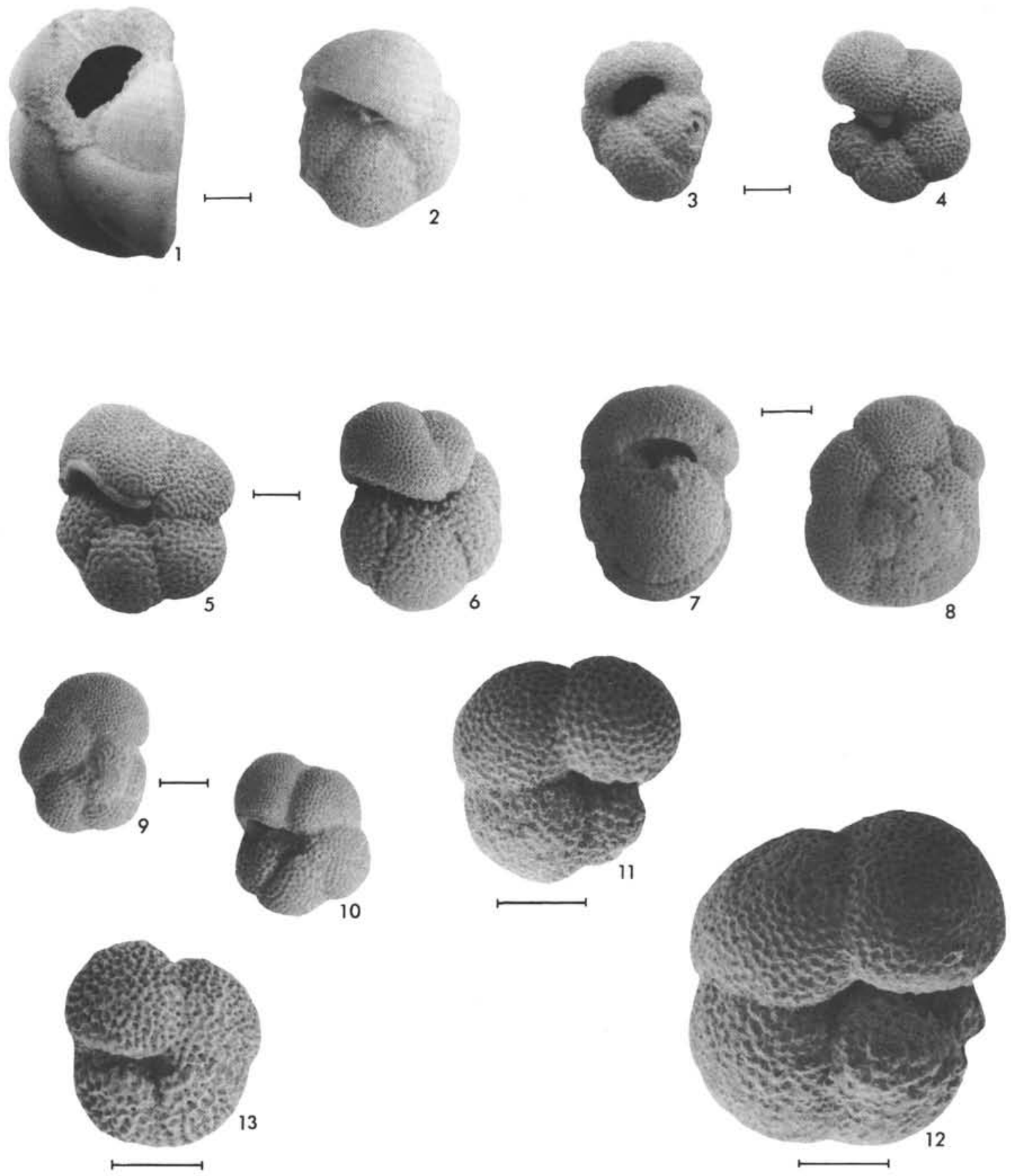

PLATE 19. Figure 1 Turborotalia (Turborotalia) cerroazulensis cerroazulensis (Cole), lateral (apertural) view. Sample 219-16-4, 52-54 cm; Zone P.18-P.19. D = $0.61 \mathrm{~mm}$. Figures 2,3 Turborotalia (Turborotalia) cerroazulensis pomeroli (Toumarkine and Bolli). Both from Sample 219-16-4, $52-54 \mathrm{~cm}$; Zone P.18-P.19. Figure 2 Ventral view. $D=0.47 \mathrm{~mm}$. Figure 3 Lateral (apertural) view. $D=0.41 \mathrm{~mm}$. Aperture retouched. Figure 4 Turborotalia (Turborotalia) humerosa humerosa (Takayanagi and Saito), ventral view. Sample 219-5,CC; Zone N.19-N.20. D = $0.42 \mathrm{~mm}$. Figure 5 Turborotalia (Turborotalia) humerosa praepulleniatina (Brönnimann and Resig), ventral view. Sample 219-6-6, 73-75 cm; Zone N.18.D = $0.53 \mathrm{~mm}$. Figures 6-8 Turborotalia (Turborotalia) humerosa trochoidea (Bizon and Bizon). All from Sample 219-34, 70-72 $\mathrm{cm}$; Zone N.22. Figure 6 Ventral view. $D=0.53 \mathrm{~mm}$. Figure 7 Lateral (apertural) view. $D=0.44 \mathrm{~mm}$. Figures 9, 10 Turborotalia (Turborotalia) mayeri (Cushman and Ellisor). Both from Sample 219-13-1, 24-26 cm; Zone N.10. Figure 9 Dorsal view. $D 0.41 \mathrm{~mm}$. Figure 10 Ventral view. $D=0.41 \mathrm{~mm}$. Figure 11 Turborotalia (Turborotalia) opima nana (Bolli), ventral view. Sample 219-15-2, 51-53 cm; Zone P.18-P.19.D =0.30 mm. Figure 12 Turborotalia (Turborotalia) opima opima (Bolli), ventral view. Sample 223-29-4, 75-76 cm; Zone P.20-P.21 $D=0.45 \mathrm{~mm}$. Figure 13 Turborotalia (Turborotalia) pachyderma (Ehrenberg), ventral view. Sample 219-1-2, 70-72 cm; Zone N.22. $D=0.27 \mathrm{~mm}$. 
PLATE 20
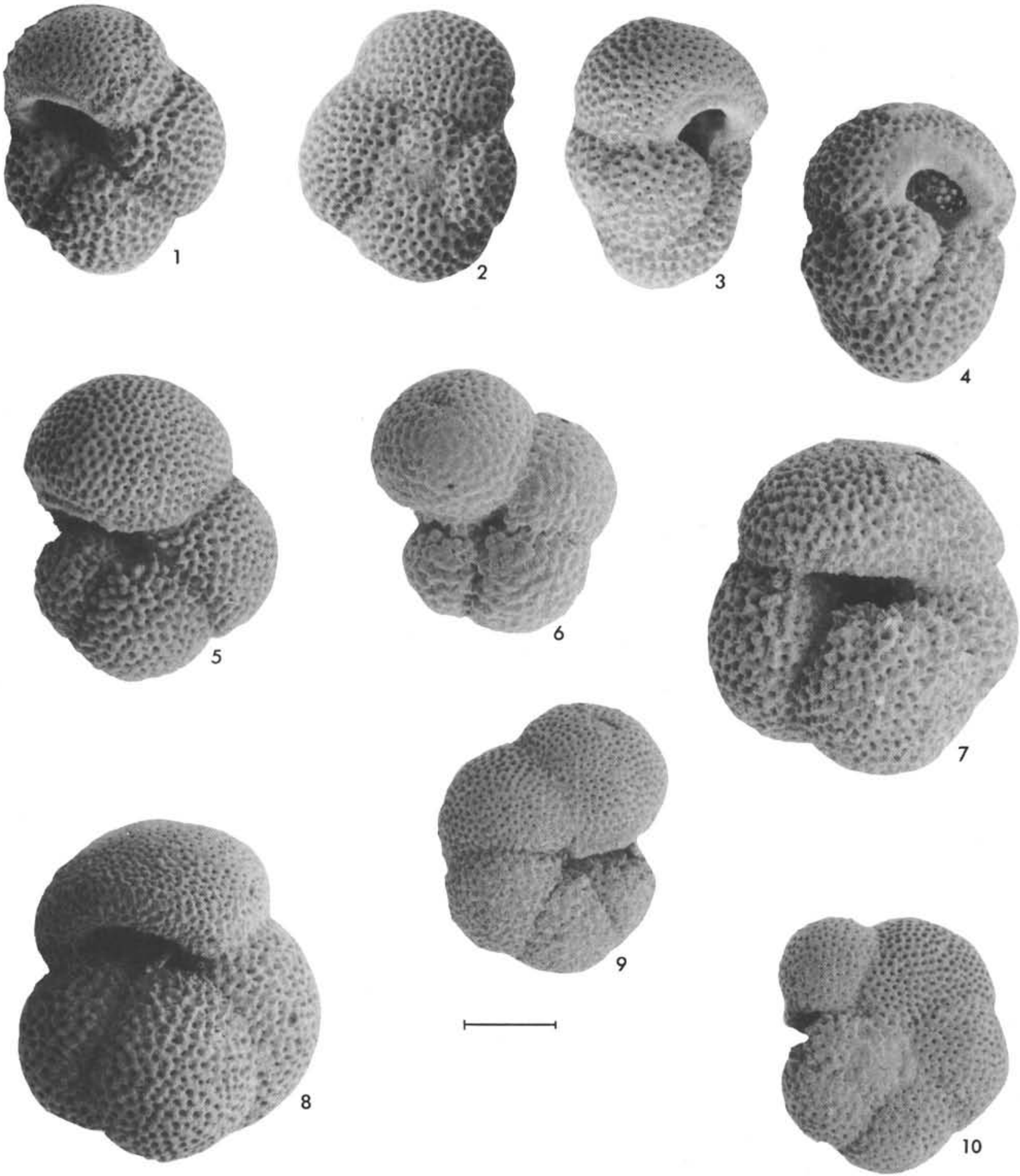

PLATE 20. All specimens are illustrated at the same magnification. Figures 2-5 Turborotalia (Turborotalia) nigriniae, n. sp. All from Sample 219-6-5, 73-75 cm; Zone N.18. Figure 1 Holotype, ventral view. $D=0.34$ mm. Figure 2 Holotype, dorsal view. Figure 3 Holotype, lateral (apertural) view. Figure 4 Paratype, lateral (apertural) view. $D=0.35 \mathrm{~mm}$. Figure 5 Paratype, ventral view. $D=0.38 \mathrm{~mm}$. Figure 6 Turborotalia (Turborotalia) pseudopima Blow, ventral view. Sample 219-1-2, 70-72 cm; Zone N.22. $D=0.34 \mathrm{~mm}$. Figure 7 Turborotalia (Turborotalia) prasaepis (Blow), ventral view. Sample 219-15-4, 51-53 cm; Zone P.18-P.19. D = 0.41 mm. Aperture slightly retouched. Figure 8 Turborotalia (Turborotalia) pseudoampliapertura (Blow and Banner), ventral view. Sample 219-15,CC; Zone P.18-P.19. D = 0.42 mm. Figures 9, 10 Turborotalia (Turborotalia) siakensis (LeRoy). Both from Sample 219-14-4, $55-57 \mathrm{~cm}$; Zone N.7-N.8. Figure 9 Ventral view. $D=0.35 \mathrm{~mm}$. Figure 10 Dorsal view. $D=0.32 \mathrm{~mm}$. 
PLATE 21
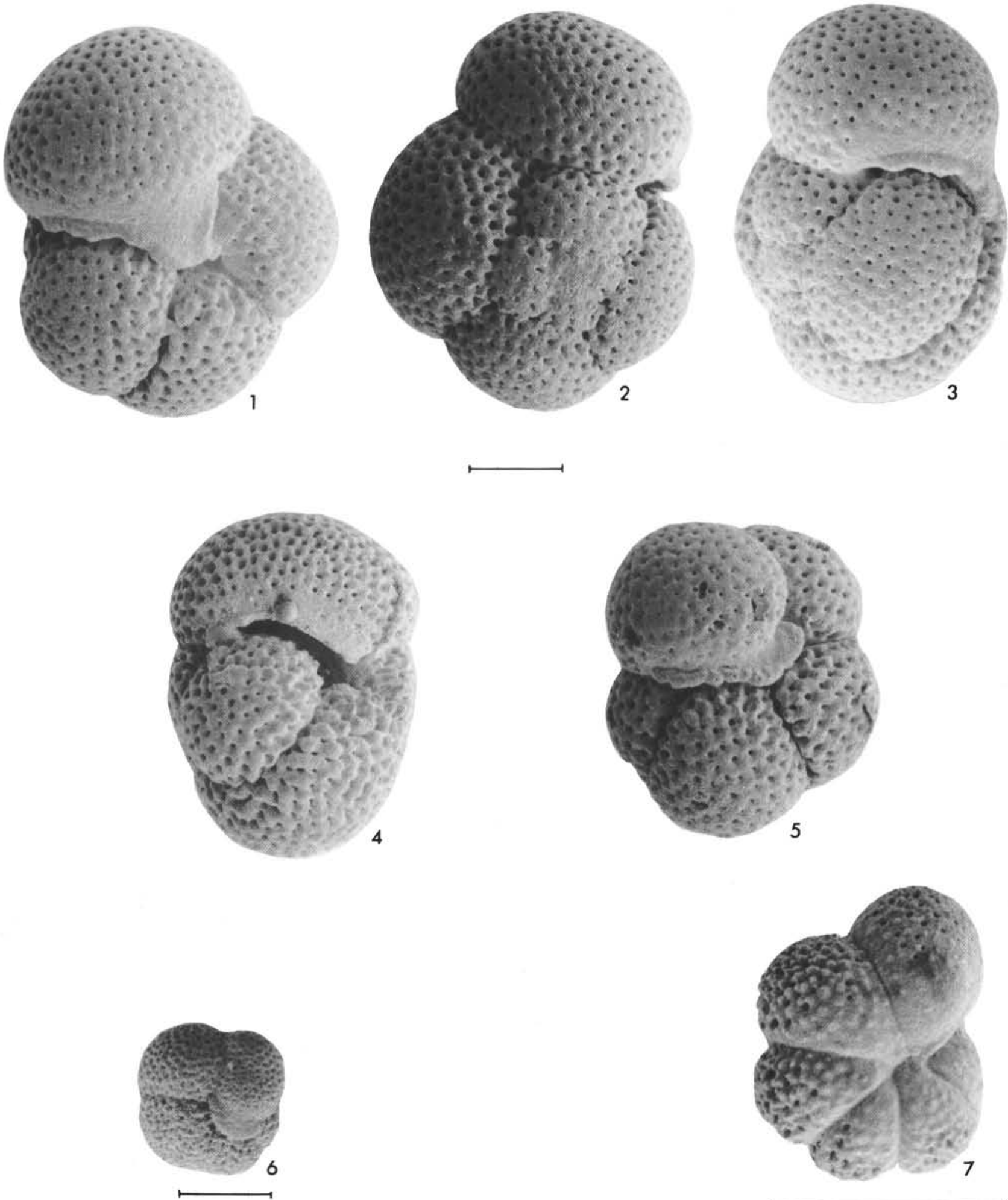

PLATE 21. All specimens are illustrated at the same magnification except Figure 7. Figures 1-5 Turborotalia (Turborotalia) vincentae, n. sp. All from Sample 219-7-2, 73-75 cm; Zone N.18. Figure 1 Holotype, ventral view. $D=0.45$ mm. Figure 2 Holotype, dorsal view. Figure 3 Holotype, lateral (apertural) view. Figure 4 Paratype, lateral (apertural) view. $D=0.41$ mm. Figure 5 Five-chambered paratype, ventral view. $D=0.38 \mathrm{~mm}$. Figure 6 Turborotalia (Turborotalia) sp. 1 , ventral view. Sample 219-19-5, 52-54 cm; Zone P.14. $D=0.19 \mathrm{~mm}$. Figure 7 Turborotalita pumilio (Parker), ventral view. Sample $219-1-1,110-112 \mathrm{~cm}$; Zone N.23. $D=0.14 \mathrm{~mm}$. 
TABLE 1A

Distribution of Planktonic Foraminiferal Species in Samples from Site 219

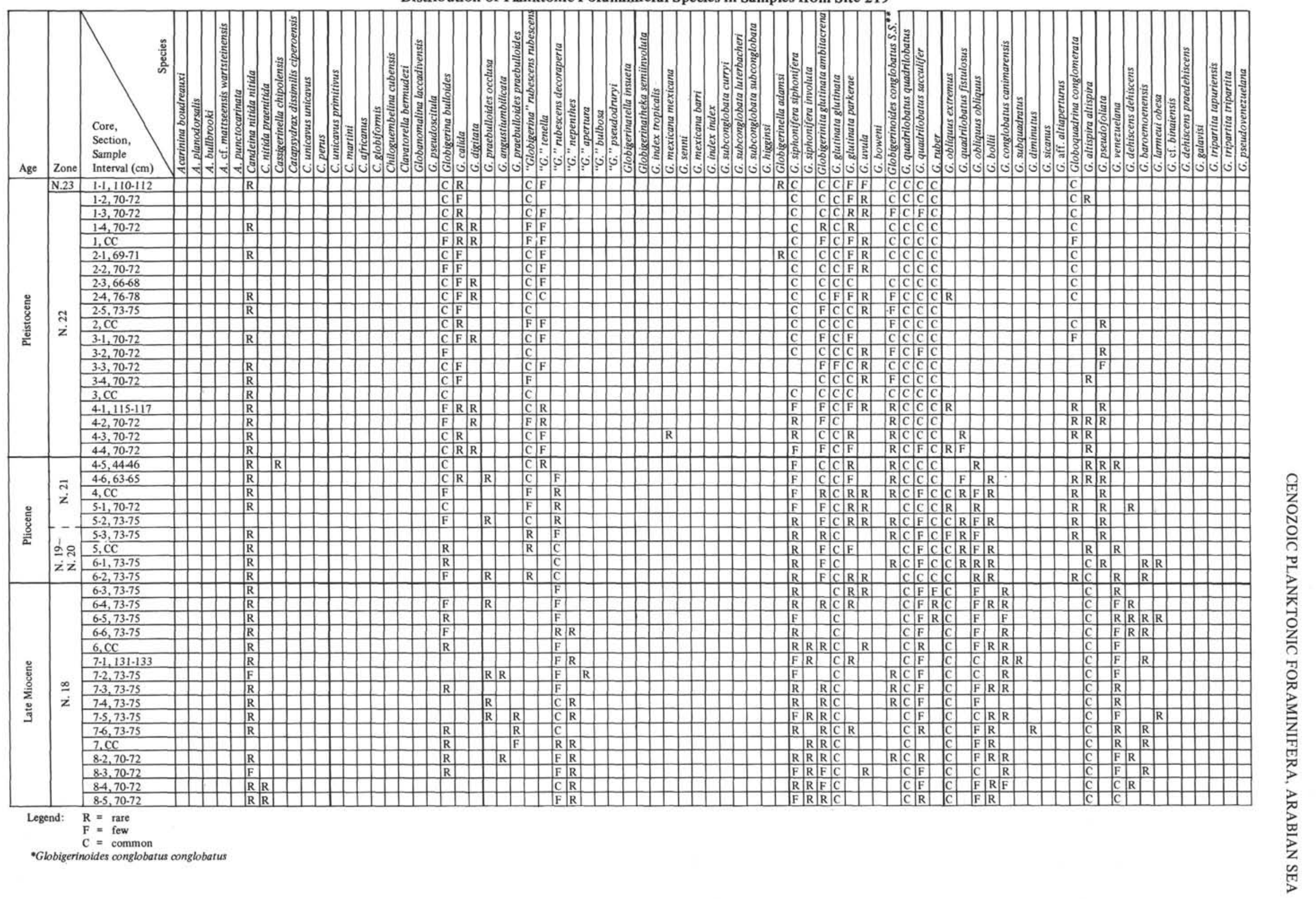




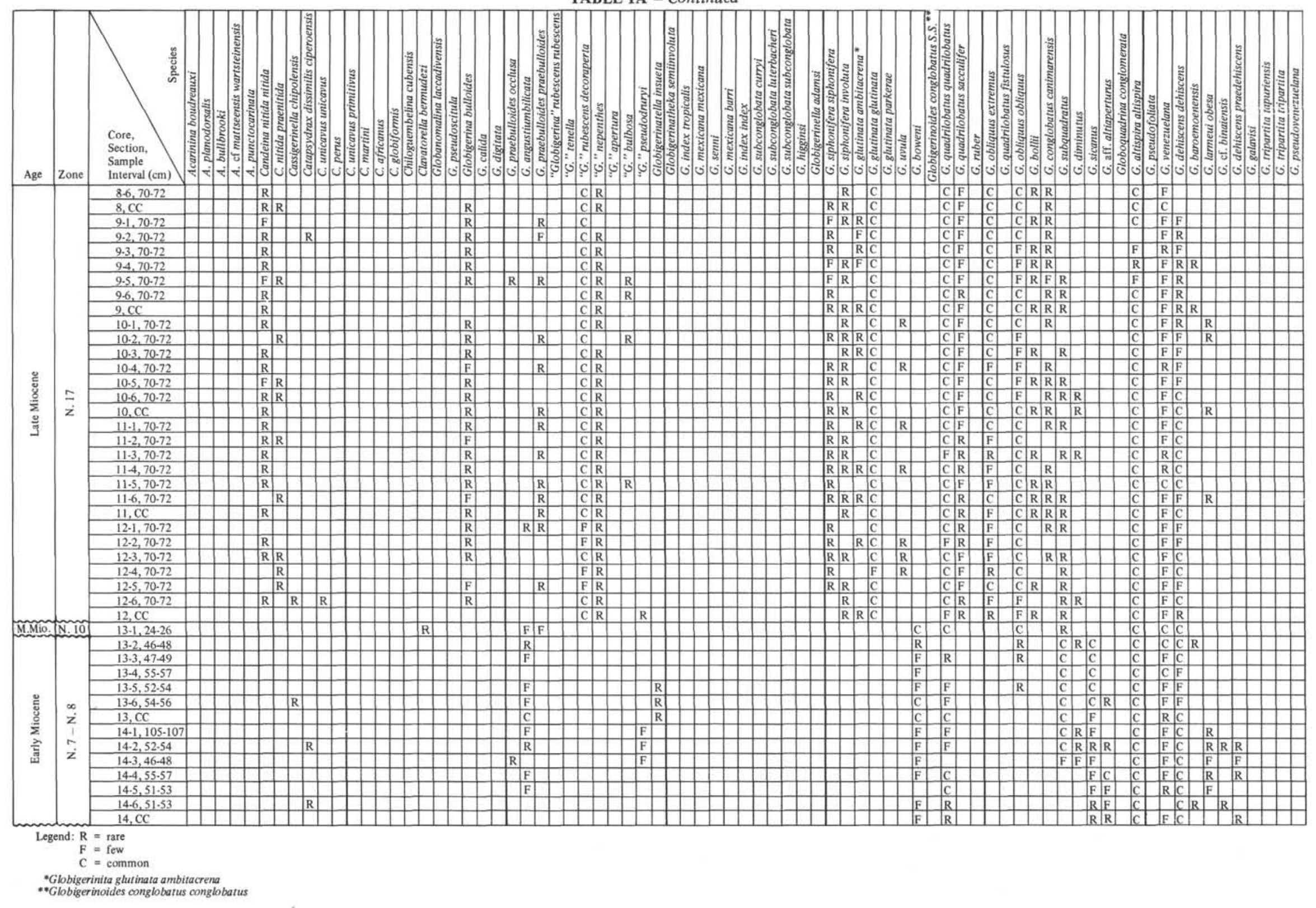


TABLE 1A - Continued

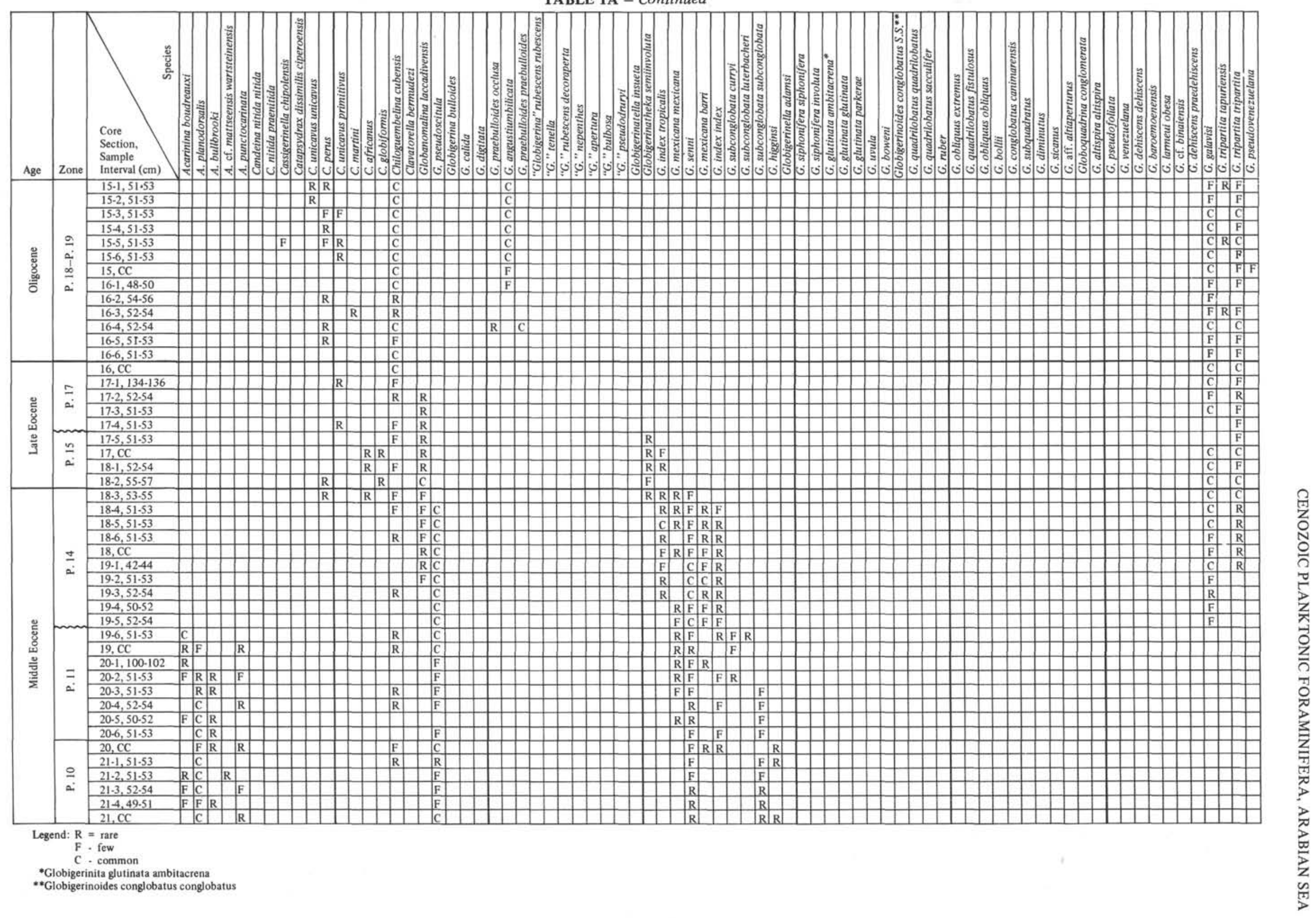


TABLE 1B

Distribution of Planktonic Foraminiferal Species in Samples from Site 219

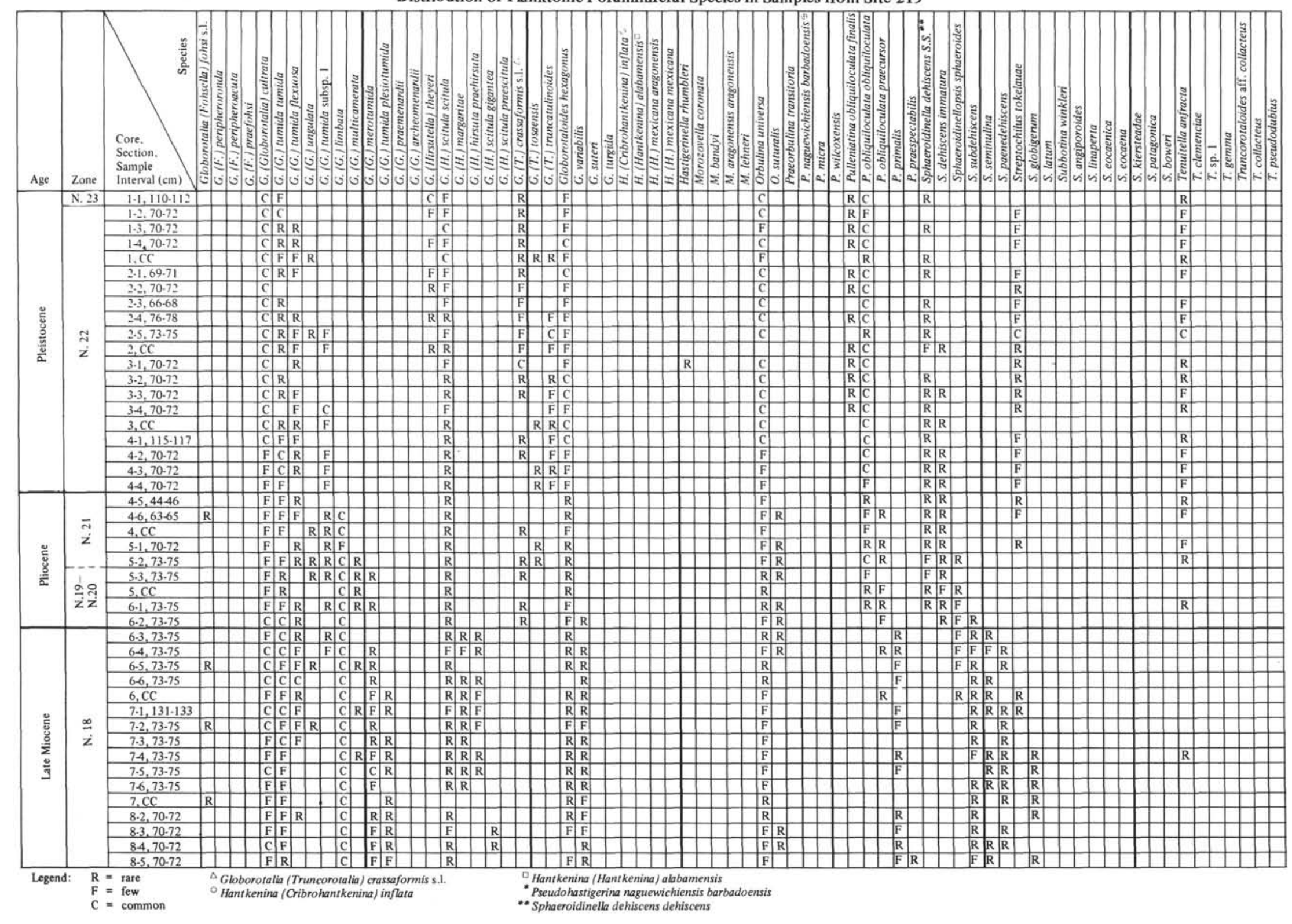


TABLE 1B - Continued

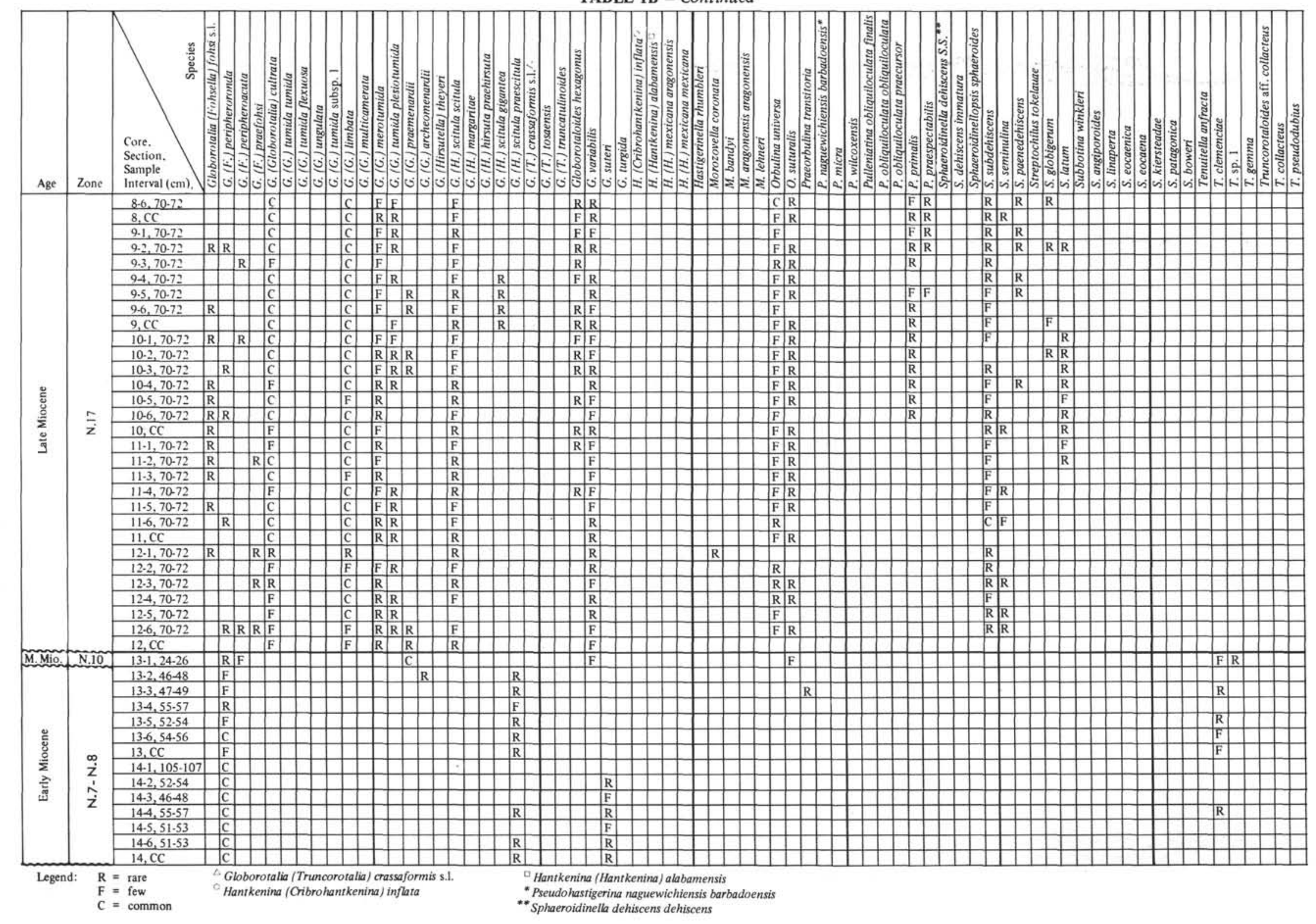




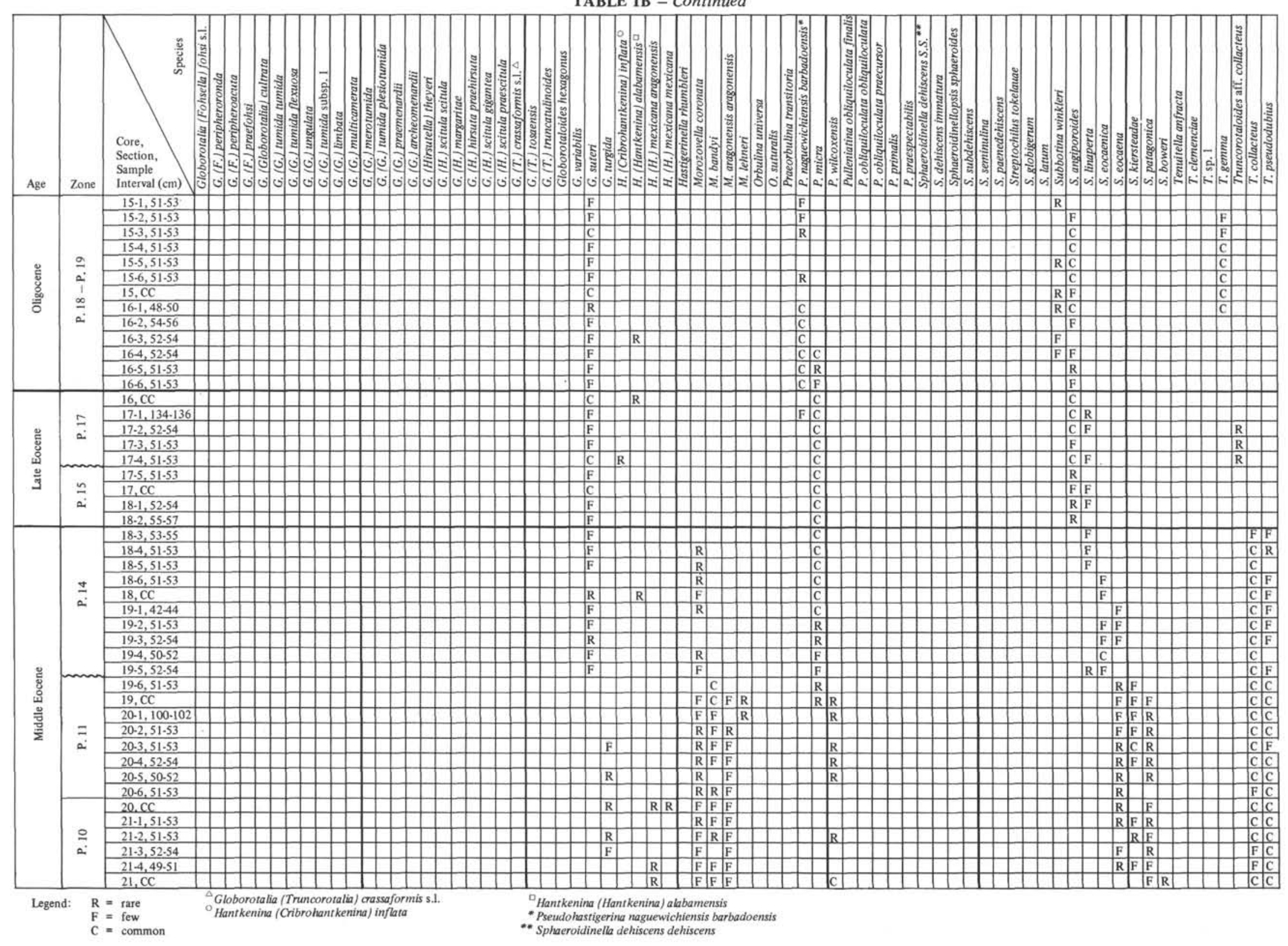


TABLE 1C

Distribution of Planktonic Foraminiferal Species in Samples from Site 219

\begin{tabular}{|c|c|c|c|c|c|c|c|c|c|c|c|c|c|c|c|c|c|c|c|c|c|c|}
\hline Age & Zone & $\begin{array}{l}\text { Core, } \\
\text { Section, } \\
\text { Sample } \\
\text { Interval }(\mathrm{cm})\end{array}$ & 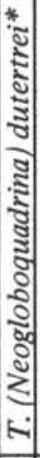 & 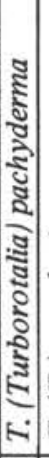 & 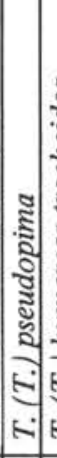 & 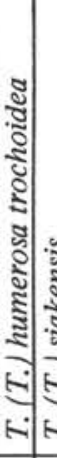 & 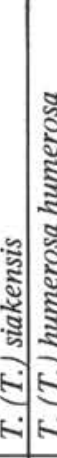 & 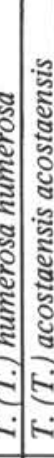 & 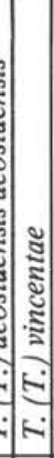 & 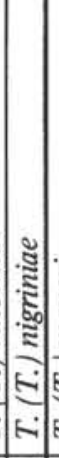 & 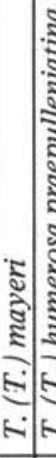 & 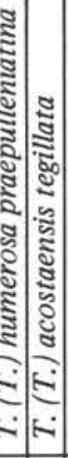 & 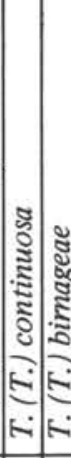 & 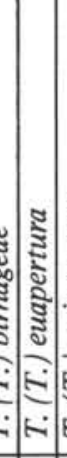 & 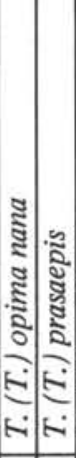 & 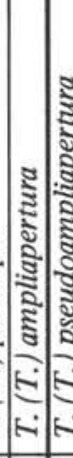 & 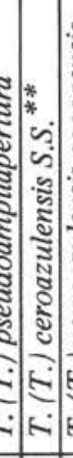 & 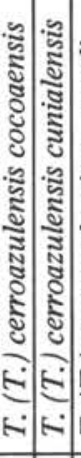 & 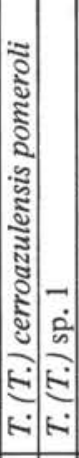 & 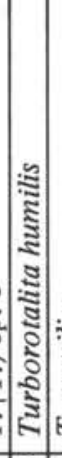 & & 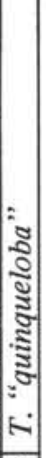 \\
\hline \multirow{20}{*}{$\begin{array}{l}\stackrel{\Xi}{0} \\
\frac{U}{0} \\
\frac{n}{0} \\
\frac{.0}{2}\end{array}$} & N. 23 & $1 \cdot 1,110-112$ & C & \begin{tabular}{|l|l}
$\mathrm{R}$ \\
\end{tabular} & & & & & & & & & & & & & & & & $\mathrm{R}$ & \begin{tabular}{l|l}
$\mathrm{R}$ & $\mathrm{C}$ \\
\end{tabular} & $\mathrm{C}$ \\
\hline & \multirow{19}{*}{$\begin{array}{l}\text { Ũ } \\
z\end{array}$} & $1-2,70-72$ & $\mathrm{C}$ & & $\mathrm{R}$ & & & & & & & & & & & & & & & $\mathrm{R}$ & & $\mathrm{C}$ \\
\hline & & $1 \cdot 3,70 \cdot 72$ & C & \begin{tabular}{|l|l}
$\mathrm{R}$ \\
\end{tabular} & & & & & & & & & & & & & & & & $\mathrm{R}$ & $\mathrm{R} / \mathrm{C}$ & $\mathrm{C}$ \\
\hline & & $1-4,70-72$ & C & \begin{tabular}{|l|l}
$\mathrm{R}$ & \\
\end{tabular} & & & & & & & & & & & & & & & & \begin{tabular}{l|l}
$\mathrm{R}$ & $\mathrm{I}$ \\
\end{tabular} & $\mathrm{R}$ & C \\
\hline & & $1, \mathrm{CC}$ & C & \begin{tabular}{|l|l} 
\\
\end{tabular} & $\mathrm{R}$ & & & & & & & & & & & & & & & \begin{tabular}{l|l}
$\mathrm{R}$ \\
\end{tabular} & & $\mathrm{C}$ \\
\hline & & $2-1,69-71$ & C & & $\mathrm{R}$ & & & & & & & & & & & & & & & $\mathrm{F}$ & & $\mathrm{C}$ \\
\hline & & $2-2,70-72$ & C & $\mathrm{F}$ & & & $\mathrm{R}$ & & & & & & & & & & & & & 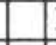 & $\mathrm{R} / \mathrm{C}$ & $\mathrm{C}$ \\
\hline & & $2-3,66-68$ & C & & & & $\mathrm{R}$ & & & & & & & & & & & & & & & $\mathrm{C}$ \\
\hline & & $2-4,76 \cdot 78$ & $\mathrm{C}$ & & & & & & & & & & & & & & & & & $\mathrm{R}$ & & $\mathrm{C}$ \\
\hline & & $2 \cdot 5,73.75$ & $\mathrm{C}$ & \begin{tabular}{|l|l}
$\mathrm{R}$ & $\mathrm{a}$ \\
\end{tabular} & $\mathrm{R}$ & & 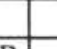 & & & & & & & & & & & & & $\mathrm{R}$ & & C \\
\hline & & $2, \mathrm{CC}$ & C & & & & $\mathrm{R}$ & & & & & & & & & & & & & & & $\mathrm{C}$ \\
\hline & & $3-1,70-72$ & $\mathrm{C}$ & & $\mathrm{R}$ & & $\mathrm{R}$ & & & & & & & & & & & & & 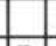 & & C \\
\hline & & $3-2,70 \cdot 72$ & C & & $\mathrm{F}$ & & $\mathrm{R}$ & & & & & & & & & & & & & $\mathrm{R}$ & & C \\
\hline & & $3-3,70 \cdot 72$ & $\mathrm{C}$ & & $\mathrm{F}$ & & & & & & & & & & & & & & & & & C \\
\hline & & $3-4,70-72$ & $\mathrm{~F}$ & & & $\mathrm{C}$ & & & & & & & & & & & & & & . & & C \\
\hline & & $3, \mathrm{CC}$ & $\mathrm{C}$ & $\mathrm{R}$ & $\mathrm{F}$ & $\mathrm{C}$ & $\mathrm{R}$ & & & & & & & & & & & & & $\mathrm{R}$ & & $\mathrm{F}$ \\
\hline & & $4-1,115-117$ & $\mathrm{C}$ & \begin{tabular}{|l|l}
$\mathrm{R}$ & $\mathrm{I}$ \\
\end{tabular} & \begin{tabular}{l|l}
$\mathrm{R}$ & $\mathrm{H}$ \\
\end{tabular} & $\mathrm{F}$ & $\mathrm{R}$ & & & & & & & & & & & & & & & $\mathrm{C}$ \\
\hline & & $4-2,70-72$ & $\mathrm{C}$ & & & $\mathrm{C}$ & & & & & & & & & & & & & & 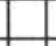 & & $\mathrm{C}$ \\
\hline & & $4-3,70-72$ & $\mathrm{~F}$ & & $\mathrm{R}$ & $\mathrm{C}$ & $\mathrm{R}$ & & & & & & & & & & & & & & & C \\
\hline & & $4-4,70-72$ & $\mathrm{~F}$ & & \begin{tabular}{|l|l}
$\mathrm{R}$ & $\mathrm{s}$ \\
\end{tabular} & $\mathrm{C}$ & & & & & & & & & & & & & & & & C \\
\hline \multirow{9}{*}{ 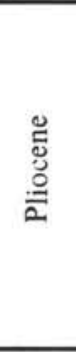 } & \multirow{5}{*}{$\begin{array}{l}\vec{v} \\
\dot{z}\end{array}$} & $4-5,44-46$ & $\mathrm{~F}$ & & & $\mathrm{C}$ & R & $\begin{array}{ll}\mathrm{R} \\
\end{array}$ & 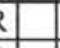 & & & & & & & & & & & & & $\mathrm{F}$ \\
\hline & & $4 \cdot 6,63-65$ & $\mathrm{C}$ & $\begin{array}{ll}\mathrm{R} & \mathrm{I} \\
\end{array}$ & $\mathrm{R}$ & C & $\mathrm{R}$ & $R$ & 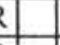 & & & & & & & & & & & $\begin{array}{lll}\mathrm{R} & \mathrm{I} \\
\end{array}$ & $\mathrm{R}$ & C \\
\hline & & $4, \mathrm{CC}$ & $\mathrm{F}$ & \begin{tabular}{|l|l}
$\mathrm{R}$ & \\
\end{tabular} & \begin{tabular}{|l|l} 
& \\
\end{tabular} & \begin{tabular}{l|l}
$F$ & $R$ \\
\end{tabular} & \begin{tabular}{l|l}
$\mathrm{R}$ & $\mathrm{R}$ \\
\end{tabular} & $\mathrm{R}$ & \begin{tabular}{l|l}
2 \\
\end{tabular} & & & & & & & & & & & D1 & $\mathrm{R} / \mathrm{C}$ & C \\
\hline & & $5-1,70 \cdot 72$ & $\mathrm{C}$ & \begin{tabular}{|l|l}
$\mathrm{R}$ \\
\end{tabular} & & \begin{tabular}{l|l}
$\mathrm{C}$ & $\mathrm{R}$ \\
\end{tabular} & \begin{tabular}{l|l}
$\mathrm{R}$ & $\mathrm{R}$ \\
\end{tabular} & $\mathrm{R}$ & \begin{tabular}{|l|l|} 
& $R$ \\
\end{tabular} & & & & & & & & & & & \begin{tabular}{l|l}
$R$ & \\
\end{tabular} & $\mathrm{R}$ & $\mathrm{F}$ \\
\hline & & $5-2,73 \cdot 75$ & $\mathrm{R}$ & & $\begin{array}{lll}R & 1 \\
\end{array}$ & \begin{tabular}{|l|l}
$\mathrm{F}$ & \\
\end{tabular} & $\mathrm{F}$ & & $\mathrm{R}$ & & & & & & & & & & & $\mathrm{R}$ & & $\mathrm{C}$ \\
\hline & \multirow{4}{*}{$\begin{array}{l}1 \\
a \\
z \\
z \\
z\end{array}$} & $5-3,73-75$ & $\mathrm{R}$ & & $\mathrm{F}$ & $\mathrm{R}$ & $\mathrm{F}$ & & & & & & & & & & & & & & $\mathrm{R}$ & $\mathrm{C}$ \\
\hline & & $5, \mathrm{CC}$ & & \begin{tabular}{|l|l}
$\mathrm{R}$ & \\
\end{tabular} & \begin{tabular}{l|l} 
& $\mathrm{I}$ \\
\end{tabular} & $\mathrm{F}$ & $\mathrm{F}$ & R & 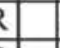 & $\mathrm{R}$ & & & & & & & & & & \begin{tabular}{|l|l}
$\mathrm{R}$ \\
\end{tabular} & & C \\
\hline & & $6-1,73 \cdot 75$ & & \begin{tabular}{|l|l}
$\mathrm{R}$ & \\
\end{tabular} & & \begin{tabular}{|l|l} 
\\
\end{tabular} & F & $\begin{array}{l}\mathrm{R} \\
\end{array}$ & 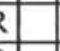 & $\mathrm{R}$ & & & & & & & & & & & & C \\
\hline & & $6-2,73-75$ & $\mathrm{R}$ & $\mathrm{R}$ & & \begin{tabular}{l|l}
$\mathrm{R}$ & $\mathrm{R}$ \\
\end{tabular} & \begin{tabular}{l|l}
$\mathrm{R}$ & $\mathrm{R}$ \\
\end{tabular} & $\mathrm{R}$ & 2 & & & & & & & & & & & $\mathrm{R}$ & & C \\
\hline \multirow{16}{*}{ 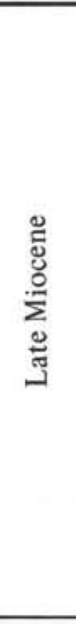 } & \multirow{16}{*}{$\frac{\infty}{z}$} & $6-3,73 \cdot 75$ & & $\mathrm{R}$ & & & \begin{tabular}{|l|l}
$\mathrm{F}$ & $\mathrm{R}$ \\
\end{tabular} & $\mathrm{R}$ & 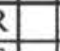 & \begin{tabular}{l|l}
$\mathrm{C}$ & $\mathrm{I}$ \\
\end{tabular} & \begin{tabular}{|l|l}
$\mathrm{R}$ & \\
\end{tabular} & & & & & & & & & & & $\mathrm{C}$ \\
\hline & & $6-4,73-75$ & & & & \begin{tabular}{l|l}
$\mathrm{R}$ & $\mathrm{R}$ \\
\end{tabular} & \begin{tabular}{l|l}
$\mathrm{R}$ & $\mathrm{F}$ \\
\end{tabular} & F & & C & & $\mathrm{R}$ & & & & & & & & & & C \\
\hline & & $6-5,73 \cdot 75$ & & & & & \begin{tabular}{l|l}
$\mathrm{R}$ & $\mathrm{R}$ \\
\end{tabular} & & & $\mathrm{C}$ & & $\mathrm{F}$ & & & & & & & & & & $\mathrm{C}$ \\
\hline & & $6-6,73-75$ & & & & & R & R & \begin{tabular}{ll|} 
& $C$ \\
\end{tabular} & $\mathrm{~F}$ & & $\mathrm{~F}$ & & & & & & & & & & C \\
\hline & & $6, \mathrm{CC}$ & & $\mathrm{R}$ & & & \begin{tabular}{l|l}
$\mathrm{R}$ & $\mathrm{F}$ \\
\end{tabular} & $\mathrm{R}$ & $\begin{array}{ll}2 & C \\
\end{array}$ & C & & $\mathrm{R}$ & & & & & & & & & & $\mathrm{C}$ \\
\hline & & $7-1,131-133$ & & $\mathrm{R}$ & & & \begin{tabular}{l|l}
$\mathrm{F}$ & $\mathrm{F}$ \\
\end{tabular} & $F$ & C & & $\begin{array}{lll}\mathrm{R} & \mathrm{F} \\
\end{array}$ & $\mathrm{F}$ & & & & & & & & & & $\mathrm{C}$ \\
\hline & & $7-2,73-75$ & & & & & \begin{tabular}{l|l}
$\mathrm{R}$ & $\mathrm{F}$ \\
\end{tabular} & F & C & $\mathrm{R}$ & & $\mathrm{R}$ & & & & & & & & & & C \\
\hline & & $7-3,73 \cdot 75$ & & $\mathrm{R}$ & & & \begin{tabular}{l|l}
$\mathrm{R}$ & $\mathrm{C}$ \\
\end{tabular} & & C & & & $\mathrm{R}$ & & & & & & & & $\mathrm{R}$ & & C \\
\hline & & $7-4,73-75$ & & & & & F & R & \begin{tabular}{l|l|}
2 & $F$ \\
\end{tabular} & & & F & & & & & & & & & & C \\
\hline & & $7-5,73-75$ & & & & & $\mathrm{~F}$ & R & $\begin{array}{ll}2 & C \\
\end{array}$ & & & $\mathrm{~F}$ & & & & & & & & & & C \\
\hline & & $7-6,73-75$ & & $\mathrm{R}$ & & & \begin{tabular}{l|l}
$\mathrm{R}$ & $\mathrm{F}$ \\
\end{tabular} & R & $\begin{array}{ll}\mathrm{R} \\
\mathrm{C}\end{array}$ & & & $\mathrm{R}$ & & & & & & & & & & C \\
\hline & & $7, \mathrm{CC}$ & & & & & \begin{tabular}{l|l}
$\mathrm{R}$ & $\mathrm{F}$ \\
\end{tabular} & $\mathrm{R}$ & \begin{tabular}{|l|l|} 
& $C$ \\
\end{tabular} & & & $\mathrm{R}$ & & & & & & & & & & C \\
\hline & & $8-2,70-72$ & & & & & \begin{tabular}{l|l}
$\mathrm{R}$ & $\mathrm{F}$ \\
\end{tabular} & F & C & & & $\mathrm{F}$ & & & & & & & & & & C \\
\hline & & $8-3,70-72$ & & $\mathrm{R}$ & & & \begin{tabular}{l|l}
$\mathrm{R}$ & $\mathrm{R}$ \\
\end{tabular} & $\begin{array}{ll}R \\
\end{array}$ & $\begin{array}{ll}2 \\
\end{array}$ & & & \begin{tabular}{l|l}
$\mathrm{R}$ & $\mathrm{R}$ \\
\end{tabular} & & & & & & & & & & C \\
\hline & & $8-4,70-72$ & & & & & \begin{tabular}{l|l}
$\mathrm{R}$ & $\mathrm{F}$ \\
\end{tabular} & R & $\begin{array}{ll}2 & F \\
\end{array}$ & & & $\mathrm{R}$ & & & & & & & & & & C \\
\hline & & $8-5,70-72$ & & & & & \begin{tabular}{l|l}
$\mathrm{R}$ & $\mathrm{C}$ \\
\end{tabular} & $\mathrm{R}$ & $\begin{array}{ll}2 & C \\
\end{array}$ & & & $F$ & & & & & & & & & & C \\
\hline
\end{tabular}


TABLE 1C - Continued

\begin{tabular}{|c|c|c|c|c|c|c|c|c|c|c|c|c|c|c|c|c|c|c|c|c|c|c|c|}
\hline Age & Zone & $\begin{array}{l}\text { Core, } \\
\text { Section, } \\
\text { Sample } \\
\text { Interval }(\mathrm{cm})\end{array}$ & 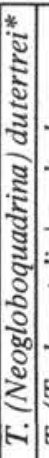 & 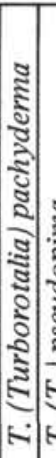 & 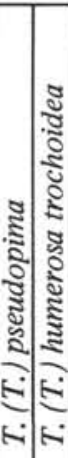 & 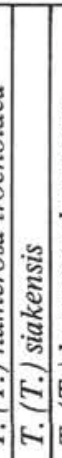 & 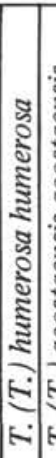 & 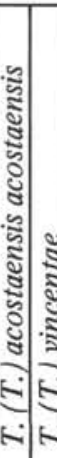 & 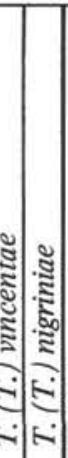 & 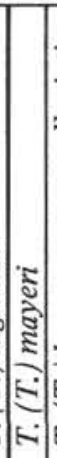 & 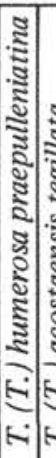 & 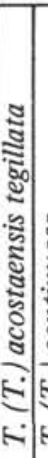 & 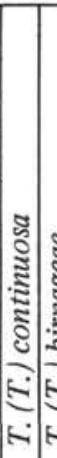 & 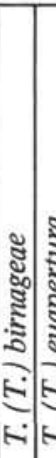 & 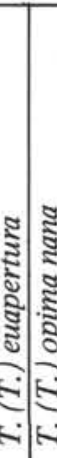 & 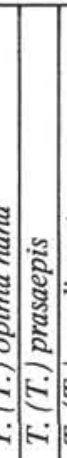 & 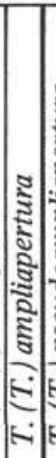 & 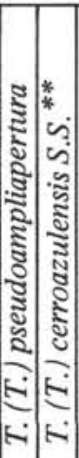 & 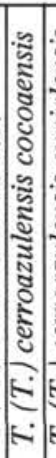 & 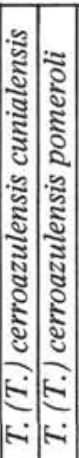 & 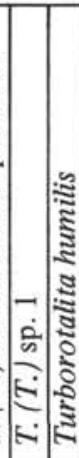 & 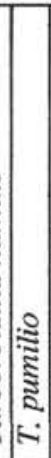 & 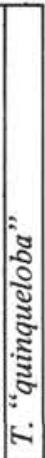 \\
\hline \multirow{30}{*}{ 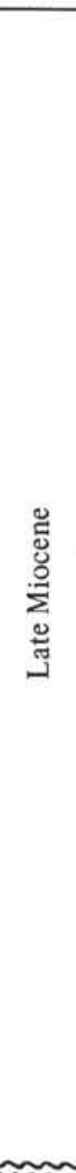 } & \multirow{30}{*}{$\stackrel{I}{z}$} & $8-6,70-72$ & & \begin{tabular}{|l|l|}
$\mathrm{R}$ \\
\end{tabular} & & $\mathrm{R}$ & \begin{tabular}{l|l}
$\mathrm{C}$ & 1 \\
\end{tabular} & \begin{tabular}{l|l}
$\mathrm{F}$ & $\mathrm{F}$ \\
\end{tabular} & \begin{tabular}{l|l|}
$\mathrm{F}$ & \\
\end{tabular} & & \begin{tabular}{l|l}
$\mathrm{R}$ & $\mathrm{F}$ \\
\end{tabular} & $\mathrm{R}$ & & & & & & & & & & & $\mathrm{C}$ \\
\hline & & $8, \mathrm{CC}$ & & \begin{tabular}{|l|}
$\mathrm{C}$ \\
\end{tabular} & & \begin{tabular}{l|l}
$\mathrm{R}$ \\
\end{tabular} & \begin{tabular}{|l|l|l}
$\mathrm{C}$ & 1 \\
\end{tabular} & \begin{tabular}{l|l}
$\mathrm{F}$ & $\mathrm{R}$ \\
\end{tabular} & $\mathrm{R}$ & & & 4 & & & & & & & & & & & $\mathrm{C}$ \\
\hline & & $9-1,70-72$ & & & & $\mathrm{R}$ & \begin{tabular}{|l|}
$\mathrm{C}$ \\
\end{tabular} & & $\mathrm{R}$ & \begin{tabular}{|l|l}
$\mathrm{R}$ \\
\end{tabular} & & $\mathrm{F}$ & & & & & & & & & & & $\mathrm{C}$ \\
\hline & & $9.2,70-72$ & & $\mathrm{~F}$ & & \begin{tabular}{l|l}
$\mathrm{R}$ \\
\end{tabular} & \begin{tabular}{|l|l}
$\mathrm{C}$ & 1 \\
\end{tabular} & \begin{tabular}{l|l}
$\mathrm{R}$ & $\mathrm{C}$ \\
\end{tabular} & $\mathrm{C}$ & \begin{tabular}{|l|l}
$\mathrm{R}$ \\
\end{tabular} & & & & & & & & & & & & & C \\
\hline & & $9-3,70-72$ & & $\mathrm{~F}$ & & \begin{tabular}{l|l}
$\mathrm{R}$ \\
\end{tabular} & \begin{tabular}{|l|l|}
$\mathrm{C}$ & 1 \\
\end{tabular} & \begin{tabular}{l|l}
$R$ & $F$ \\
\end{tabular} & $\mathrm{~F}$ & & \begin{tabular}{l|l}
$\mathrm{R}$ & $\mathrm{I}$ \\
\end{tabular} & $\mathrm{R}$ & & & & & & & & & & & C \\
\hline & & $9-4,70-72$ & & $\mathrm{~F}$ & & $\mathrm{~F}$ & \begin{tabular}{|l|l}
$\mathrm{C}$ & $\mathrm{I}$ \\
\end{tabular} & \begin{tabular}{l|l}
$\mathrm{R}$ & $\mathrm{F}$ \\
\end{tabular} & $\mathrm{F}$ & 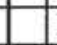 & \begin{tabular}{|l|l}
$\mathrm{R}$ & $\mathrm{I}$ \\
\end{tabular} & $\mathrm{R}$ & & & & & & & & & & & C \\
\hline & & $9-5,70-72$ & & & & $\mathrm{~F}$ & \begin{tabular}{l|l}
$\mathrm{C}$ \\
\end{tabular} & $\mathrm{F}$ & $\mathrm{F}$ & \begin{tabular}{l|l}
$\mathrm{R}$ \\
\end{tabular} & & $\mathrm{R}$ & & & & & & & & & & & $\mathrm{C}$ \\
\hline & & $9-6,70-72$ & & $\mathrm{R}$ & & $\mathrm{F}$ & \begin{tabular}{|l|l|}
$\mathrm{F}$ & $\mathrm{I}$ \\
\end{tabular} & \begin{tabular}{l|l}
$R$ & $F$ \\
\end{tabular} & $\mathrm{~F}$ & $\mathrm{R}$ & & $\mathrm{R}$ & & & & & & & & & & & C \\
\hline & & $9, \mathrm{CC}$ & & $\mathrm{F}$ & & $\mathrm{F}$ & \begin{tabular}{|l|l|}
$\mathrm{F}$ & $\mathrm{I}$ \\
\end{tabular} & \begin{tabular}{l|l}
$\mathrm{F}$ & $\mathrm{R}$ \\
\end{tabular} & $\mathrm{R}$ & $\mathrm{F}$ & & $\mathrm{F}$ & & & & & & & & & & & $\mathrm{C}$ \\
\hline & & $10-1,70-72$ & & $\mathrm{~F}$ & & $\mathrm{~F}$ & \begin{tabular}{|l|l}
$\mathrm{C}$ & $\mathrm{I}$ \\
\end{tabular} & \begin{tabular}{l|l}
$\mathrm{F}$ & $\mathrm{F}$ \\
\end{tabular} & $\mathrm{F}$ & $\mathrm{F}$ & & $\mathrm{R}$ & & & & & & & & & & & C \\
\hline & & $10-2,70-72$ & & & & $\mathrm{~F}$ & \begin{tabular}{|l|l}
$\mathrm{C}$ & $\mathrm{I}$ \\
\end{tabular} & \begin{tabular}{l|l}
$\mathrm{F}$ & \\
\end{tabular} & & $\mathrm{F}$ & & $\mathrm{R}$ & & & & & & & & & & & C \\
\hline & & $10-3,70-72$ & & & & \begin{tabular}{|l|l}
$\mathrm{F}$ \\
\end{tabular} & \begin{tabular}{|l|l|}
$\mathrm{C}$ & $\mathrm{I}$ \\
\end{tabular} & $\mathrm{F}$ & & $\mathrm{F}$ & $\mathrm{H}$ & $\mathrm{F}$ & & & & & & & & & & & C \\
\hline & & $10-4,70-72$ & & $\mathrm{R}$ & & $\mathrm{F}$ & \begin{tabular}{l|l}
$\mathrm{C}$ & $\mathrm{C}$ \\
\end{tabular} & $\mathrm{C}$ & & $\mathrm{F}$ & \begin{tabular}{|l|l}
$R$ & 1 \\
\end{tabular} & $\mathrm{~F}$ & & & & & & & & & & & C \\
\hline & & $10-5,70-72$ & & & & $\mathrm{~F}$ & $\mathrm{C}$ & $\mathrm{C}$ & & $\mathrm{F}$ & & $\mathrm{C}$ & & & & & & & & & & & C \\
\hline & & $10-6,70-72$ & & & & $\mathrm{R} /$ & \begin{tabular}{|l|l}
$\mathrm{C}$ & $\mathrm{C}$ \\
\end{tabular} & $\mathrm{C}$ & & $\mathrm{F}$ & & $\mathrm{F}$ & & & & & & & & & & & $\mathrm{C}$ \\
\hline & & $10, \mathrm{CC}$ & & $\mathrm{R}$ & & $\mathrm{F}$ & \begin{tabular}{l|l}
$\mathrm{C}$ & $\mathrm{C}$ \\
\end{tabular} & $\mathrm{C}$ & & $\mathrm{R}$ & & C & & & & & & & & & & & C \\
\hline & & $11-1,70-72$ & & $\mathrm{R}$ & & C & $\begin{array}{lll}\mathrm{C} & \mathrm{C} \\
\end{array}$ & $\mathrm{C}$ & & $\mathrm{F}$ & & $\mathrm{C}$ & & & & & & & & & & & $\mathrm{C}$ \\
\hline & & $11-2,70-72$ & & & & \begin{tabular}{l|l} 
C \\
\end{tabular} & $\mathrm{C}$ & $\mathrm{C}$ & & $\mathrm{F}$ & & $\mathrm{F}$ & & & & & & & & & & & C \\
\hline & & $11-3,70-72$ & & & & F & \begin{tabular}{|l|l}
$\mathrm{F}$ & $\mathrm{C}$ \\
\end{tabular} & $\mathrm{C}$ & & $\mathrm{F}$ & & F & & & & & & & & & & & $\mathrm{C}$ \\
\hline & & $11-4,70-72$ & & $\mathrm{R}$ & & $\mathrm{F}$ & \begin{tabular}{|l|l}
$\mathrm{C}$ & $\mathrm{C}$ \\
\end{tabular} & $\mathrm{C}$ & & $\mathrm{R}$ & & \begin{tabular}{l|l} 
\\
\end{tabular} & & & & & & & & & & & $\mathrm{C}$ \\
\hline & & $11-5,70-72$ & & & & $\mathrm{~F}$ & \begin{tabular}{l|l}
$\mathrm{C}$ & $\mathrm{C}$ \\
\end{tabular} & $\mathrm{C}$ & & $\mathrm{F}$ & & F & $\mathrm{R}$ & & & & & & & & & & C \\
\hline & & $11-6,70-72$ & & & & $\mathrm{C}$ & \begin{tabular}{l|l}
$\mathrm{C}$ & $\mathrm{C}$ \\
\end{tabular} & $\mathrm{C}$ & & $\mathrm{F}$ & & \begin{tabular}{|l|l|}
$F$ \\
\end{tabular} & & & & & & & & & & & C \\
\hline & & $11, \mathrm{CC}$ & & & & F & \begin{tabular}{|l|l}
$\mathrm{C}$ & $\mathrm{F}$ \\
\end{tabular} & $\mathrm{F}$ & & $\mathrm{F}$ & & $\mathrm{F}$ & & & & & & & & & & & C \\
\hline & & $12-1,70-72$ & & & & $\begin{array}{lll} & 1 \\
\end{array}$ & \begin{tabular}{|l|l}
$\mathrm{F}$ & $\mathrm{C}$ \\
\end{tabular} & $\mathrm{C}$ & & $\mathrm{F}$ & & $\mathrm{F}$ & & & & & & & & & & & $\mathrm{C}$ \\
\hline & & $12-2,70-72$ & & & & $\begin{array}{ll} \\
\end{array}$ & $\mathrm{F}$ & $\mathrm{C}$ & & $\mathrm{F}$ & & $\mathrm{F}$ & & & & & & & & & & & C \\
\hline & & $12-3,70-72$ & & & & \begin{tabular}{|l|l}
$F$ \\
\end{tabular} & \begin{tabular}{l|l}
$\mathrm{C}$ & $\mathrm{C}$ \\
\end{tabular} & C & & $\mathrm{F}$ & & $\mathrm{F}$ & & & & & & & & & & & $\mathrm{C}$ \\
\hline & & $12-4,70-72$ & & & & $\begin{array}{lll} & 1 \\
\end{array}$ & \begin{tabular}{|l|l}
$\mathrm{F}$ & $\mathrm{C}$ \\
\end{tabular} & $\mathrm{C}$ & & $F$ & & $\mathrm{~F}$ & & & & & & & & & & & $\mathrm{C}$ \\
\hline & & $12-5,70-72$ & & & & \begin{tabular}{l|l} 
C & 1 \\
\end{tabular} & $\mathrm{~F} / \mathrm{C}$ & $\mathrm{C}$ & & $F$ & & \begin{tabular}{l|l}
$\mathrm{C}$ \\
\end{tabular} & & & & & & & & & & & $\mathrm{C}$ \\
\hline & & $12-6,70-72$ & & & & C: 1 & \begin{tabular}{|l|l|}
$\mathrm{F}$ & $\mathrm{F}$ \\
\end{tabular} & $\mathrm{F}$ & & $\mathrm{F}$ & & $\mathrm{R}$ & $\mathrm{R}$ & & & & & & & & & & $\mathrm{C}$ \\
\hline & & $12, \mathrm{CC}$ & & & & C 1 & \begin{tabular}{|l|l|}
$\mathrm{R}$ & $\mathrm{H}$ \\
\end{tabular} & $\mathrm{F}$ & & $\mathrm{F}$ & & & $\mathrm{R}$ & & & & & & & & & & C \\
\hline & N.10 & $13-1,24-26$ & & & & \begin{tabular}{|l|l}
$\mathrm{C}$ \\
\end{tabular} & & & & C & & & & & & & & & & & & & \\
\hline \multirow{13}{*}{ 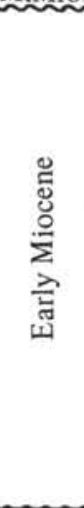 } & \multirow{13}{*}{$\begin{array}{c}\infty \\
\dot{z} \\
1 \\
r \\
z\end{array}$} & $13-2,46-48$ & & & & $\mathrm{C}$ & & & & & & & \begin{tabular}{|l|l|}
$\mathrm{F}$ & $\mathrm{F}$ \\
\end{tabular} & $\mathrm{F}$ & & & & & & & & & \\
\hline & & $13-3,47-49$ & & & & C & & & & & & & & $\mathrm{F}$ & & & & & & & & & \\
\hline & & $13-4,55-57$ & & & & C & & & & & & & \begin{tabular}{|l|l}
$\mathrm{F}$ & $\mathrm{F}$ \\
\end{tabular} & $\mathrm{F}$ & & & & & & & & & \\
\hline & & $13-5,52-54$ & & & & C & & & & & & & & $\mathrm{F}$ & & & & & & & & & \\
\hline & & $13-6,54-56$ & & & & $\mathrm{C}$ & & & & & & & & $\mathrm{F}$ & & & & & & & & & \\
\hline & & $13, \mathrm{CC}$ & & & & C & & & & & & & \begin{tabular}{|l|l|}
$\mathrm{F}$ & $\mathrm{F}$ \\
\end{tabular} & \begin{tabular}{l|l}
$\mathrm{R}$ & \\
\end{tabular} & & & & & & & & & \\
\hline & & $14-1,105-107$ & & & & $\mathrm{C}$ & & & & & & & & \begin{tabular}{l|l}
$\mathrm{F}$ & $\mathrm{R}$ \\
\end{tabular} & $\mathrm{R}$ & & & & & & & & \\
\hline & & $14-2,52-54$ & & & & $\mathrm{C}$ & & & & & & & & \begin{tabular}{l|l}
$\mathrm{F}$ \\
\end{tabular} & & & & & & & & & \\
\hline & & $14-3,46-48$ & & & & $\mathrm{C}$ & & & & & & & & $\mathrm{F}$ & & & & & & & & & \\
\hline & & $14-4,55-57$ & & & & C & & & & & & & & $\mathrm{R}$ & & & & & & & & & \\
\hline & & $14-5,51-53$ & & & & $\mathrm{C}$ & & & & & & & \begin{tabular}{l|l}
$\mathrm{R}$ & $\mathrm{R}$ \\
\end{tabular} & $\mathrm{R}$ & & & & & & & & & \\
\hline & & $14-6,51-53$ & & & & C & & & & & & & & \begin{tabular}{l|l}
$\mathrm{F}$ & $\mathrm{R}$ \\
\end{tabular} & $\mathrm{R}$ & & & & & & & & \\
\hline & & $14, \mathrm{CC}$ & & & & $\mathrm{C}$ & & & & & & & & \begin{tabular}{l|l}
$\mathrm{F}$ & \\
\end{tabular} & & & & & & & & & \\
\hline
\end{tabular}


TABLE 1C - Continued

\begin{tabular}{|c|c|c|c|c|c|c|c|c|c|c|c|c|c|c|c|c|c|c|c|c|}
\hline Age & Zone & $\begin{array}{l} \\
\text { Core, } \\
\text { Section, } \\
\text { Sample } \\
\text { Interval }(\mathrm{cm})\end{array}$ & 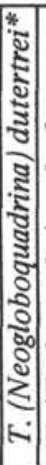 & 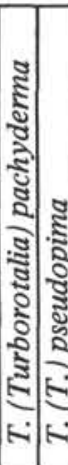 & 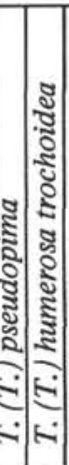 & (1) & 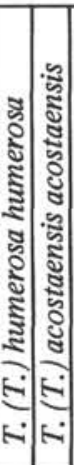 & 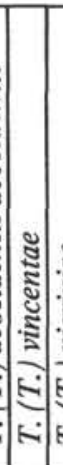 & 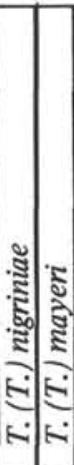 & 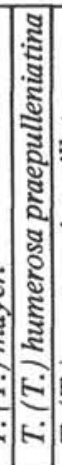 & 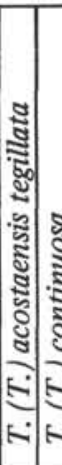 & 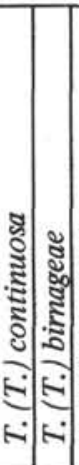 & 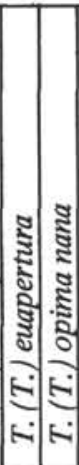 & 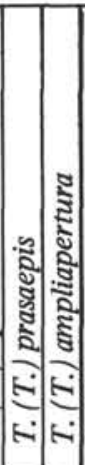 & 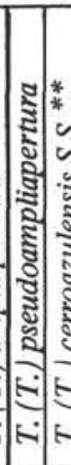 & 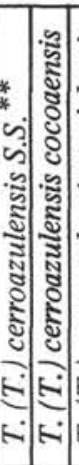 & 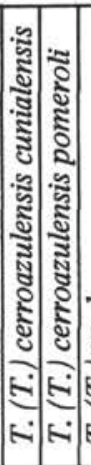 & 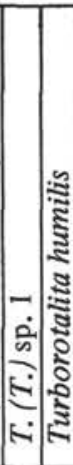 & 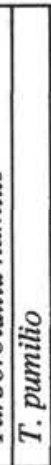 & 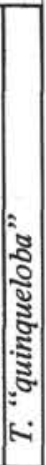 \\
\hline \multirow{13}{*}{ 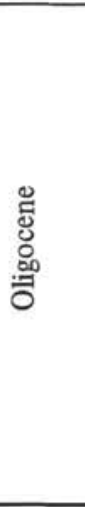 } & \multirow{13}{*}{$\begin{array}{l}a \\
a \\
1 \\
\infty \\
0 \\
0\end{array}$} & $15-1,51-53$ & & & & & & & & & & & C & C & 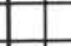 & & & & & \\
\hline & & $15-2,51-53$ & & & & & & & & & & & C & \begin{tabular}{|l|l|}
$\mathrm{C}$ & \\
\end{tabular} & - & & & & & \\
\hline & & $15-3,51-53$ & & & & & & & & & & & $\mathrm{~F}$ & \begin{tabular}{|l|l|}
$\mathrm{F}$ & $\mathrm{F}$ \\
\end{tabular} & $R$ & 7 & 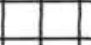 & & & \\
\hline & & $15-4,51-53$ & & & & & & & & & & & $\mathrm{R}$ & \begin{tabular}{|l|l|}
$\mathrm{F}$ & \\
\end{tabular} & & & 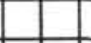 & & & \\
\hline & & $15-5,51-53$ & & & & & & & & & & & $\mathrm{~F}$ & \begin{tabular}{|l|l|}
$\mathrm{F}$ & $\mathrm{R}$ \\
\end{tabular} & & & - & & & \\
\hline & & $15-6,51-53$ & & & & & & & & & & & & \begin{tabular}{|l|l|}
$\mathrm{F}$ & $\mathrm{R}$ \\
\end{tabular} & 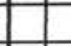 & & 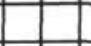 & - & & \\
\hline & & $15, \mathrm{CC}$ & & & & & & & & & & & & \begin{tabular}{|l|l|} 
& $F$ \\
\end{tabular} & $\mathrm{R}$ & & 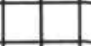 & & & \\
\hline & & $16-1,48-50$ & & & & & & & & & & & & \begin{tabular}{|l|l|}
$\mathrm{F}$ & $\mathrm{F}$ \\
\end{tabular} & $\mathrm{R}$ & & & & & \\
\hline & & $16-2,54-56$ & & & & & & & & & & & & & 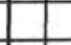 & & & & & \\
\hline & & $16-3,52-54$ & & & & & & & & & & & & \begin{tabular}{|l|l|} 
& $R$ \\
\end{tabular} & & & 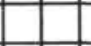 & & & \\
\hline & & $16-4,52-54$ & & & & & & & & & & & & \begin{tabular}{|l|l|}
$\mathrm{F}$ & $\mathrm{C}$ \\
\end{tabular} & \begin{tabular}{|l|l}
$\mathrm{R}$ & $\mathrm{R}$ \\
\end{tabular} & \begin{tabular}{l|l|}
$\mathrm{R}$ & $\mathrm{R}$ \\
\end{tabular} & \begin{tabular}{|l|l|}
$F$ & $R$ \\
\end{tabular} & & & \\
\hline & & $16-5,51-53$ & & & & & & & & & & & & \begin{tabular}{|l|l|}
$R$ & $R$ \\
\end{tabular} & & 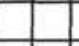 & \begin{tabular}{|l|l} 
& \\
\end{tabular} & & & \\
\hline & & $16-6,51-53$ & & & & & & & & & & & & \begin{tabular}{|l|l|}
$R$ & $R$ \\
\end{tabular} & $\mathrm{R}$ & & 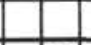 & & & \\
\hline \multirow{9}{*}{ 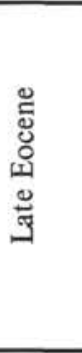 } & \multirow{5}{*}{$\stackrel{I}{a}$} & $16, \mathrm{CC}$ & & & & & & & & & & & $\mathrm{R}$ & \begin{tabular}{|l|l|} 
& $F$ \\
\end{tabular} & & $\mathrm{R}$ & $\mathrm{R}$ & & & \\
\hline & & $17-1,134-136$ & & & & & & & & & & & & & & & $\mathrm{R}$ & & & \\
\hline & & $17-2,52-54$ & & & & & & & & & & & & & & & & & & \\
\hline & & $17-3,51-53$ & & & & & & & & & & & & & & & $\mathrm{R}$ & & & \\
\hline & & $17-4,51-53$ & & & & & & & & & & & & $\mathrm{R}$ & & & $\mathrm{R}$ & & & \\
\hline & \multirow{4}{*}{$\frac{n}{a}$} & $17-5,51-53$ & & & & & & & & & & & & & & $\mathrm{R}$ & & & & \\
\hline & & $17, \mathrm{CC}$ & & & & & & & & & & & & & & \begin{tabular}{|l|l|}
$\mathrm{F}$ & $\mathrm{R}$ \\
\end{tabular} & & & & \\
\hline & & $18-1,52-54$ & & & & & & & & & & & & & & \begin{tabular}{l|l}
$\mathrm{R}$ & \\
\end{tabular} & 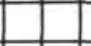 & & & \\
\hline & & $18-2,55-57$ & & & & & & & & & & & & & & & & & & \\
\hline \multirow{24}{*}{ 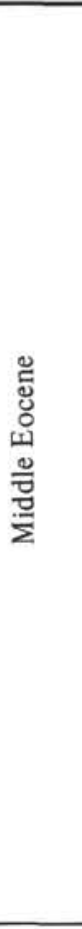 } & \multirow{10}{*}{$\frac{\Xi}{a}$} & $18-3,53-55$ & & & & & & & & & & & & & & & $\mathrm{R}$ & & & \\
\hline & & $18-4,51-53$ & & & & & & & & & & & & & & & & & & \\
\hline & & $18-5,51-53$ & & & & & & & & & & & & & & & & $\mathrm{R}$ & & \\
\hline & & $18-6,51-53$ & & & & & & & & & & & & & & \begin{tabular}{l|l|}
$R$ & $R$ \\
\end{tabular} & & $\mathrm{R}$ & & \\
\hline & & $18, \mathrm{CC}$ & & & & & & & & & & & & & & \begin{tabular}{l|l}
$\mathrm{R}$ & \\
\end{tabular} & \begin{tabular}{|l|l} 
\\
\end{tabular} & $\mathrm{R}$ & & \\
\hline & & $19-1,42-44$ & & & & & & & & & & & & & & $\mathrm{R}$ & $\begin{array}{lll}R & 1 \\
\end{array}$ & $\mathrm{R}$ & & \\
\hline & & $19-2,51-53$ & & & & & & & & & & & & & & $\mathrm{R}$ & $\mathrm{F}$ & & & \\
\hline & & $19-3,52-54$ & & & & & & & & & & & & & & $\mathrm{~F}$ & \begin{tabular}{|l|l|}
$F$ \\
\end{tabular} & & & \\
\hline & & $19-4,50-52$ & & & & & & & & & & & & & & & \begin{tabular}{l|l} 
R & I \\
\end{tabular} & $\mathrm{F}$ & & \\
\hline & & $19-5,52-54$ & & & & & & & & & & & & & & & $F$ & C & & \\
\hline & \multirow{8}{*}{$\vec{z}$} & $19-6,51-53$ & & & & & & & & & & & & & & & $\mathrm{R}$ & & & \\
\hline & & $19, \mathrm{CC}$ & & & & & & & & & & & & & & & C & & & \\
\hline & & $20-1,100-102$ & & & & & & & & & & & & & & & $\mathrm{R}$ & & & \\
\hline & & $20-2,51-53$ & & & & & & & & & & & & & & & $\mathrm{R}$ & & & \\
\hline & & $20-3,51-53$ & & & & & & & & & & & & & & & & & & \\
\hline & & $20-4,52-54$ & & & & & & & & & & & & & & & & & & \\
\hline & & $20-5,50-52$ & & & & & & & & & & & & & & & & & & \\
\hline & & $20-6,51-53$ & & & & & & & & & & & & & & & & & & \\
\hline & \multirow{6}{*}{$\frac{O}{a}$} & $20, \mathrm{CC}$ & & & & & & & & & & & & & & & & & & \\
\hline & & $21-1,51-53$ & & & & & & & & & & & & & & & & & & \\
\hline & & $21-2,51-53$ & & & & & & & & & & & & & & & & & & \\
\hline & & $21-3,52-54$ & & & & & & & & & & & & & & & & & & \\
\hline & & $21-4,49-51$ & & & & & & & & & & & & & & & & & & \\
\hline & & $21, \mathrm{CC}$ & & & & & & & & & & & & & & & F & & & \\
\hline
\end{tabular}


TABLE 2

Distribution of Foraminiferal Species in Samples from Site 220

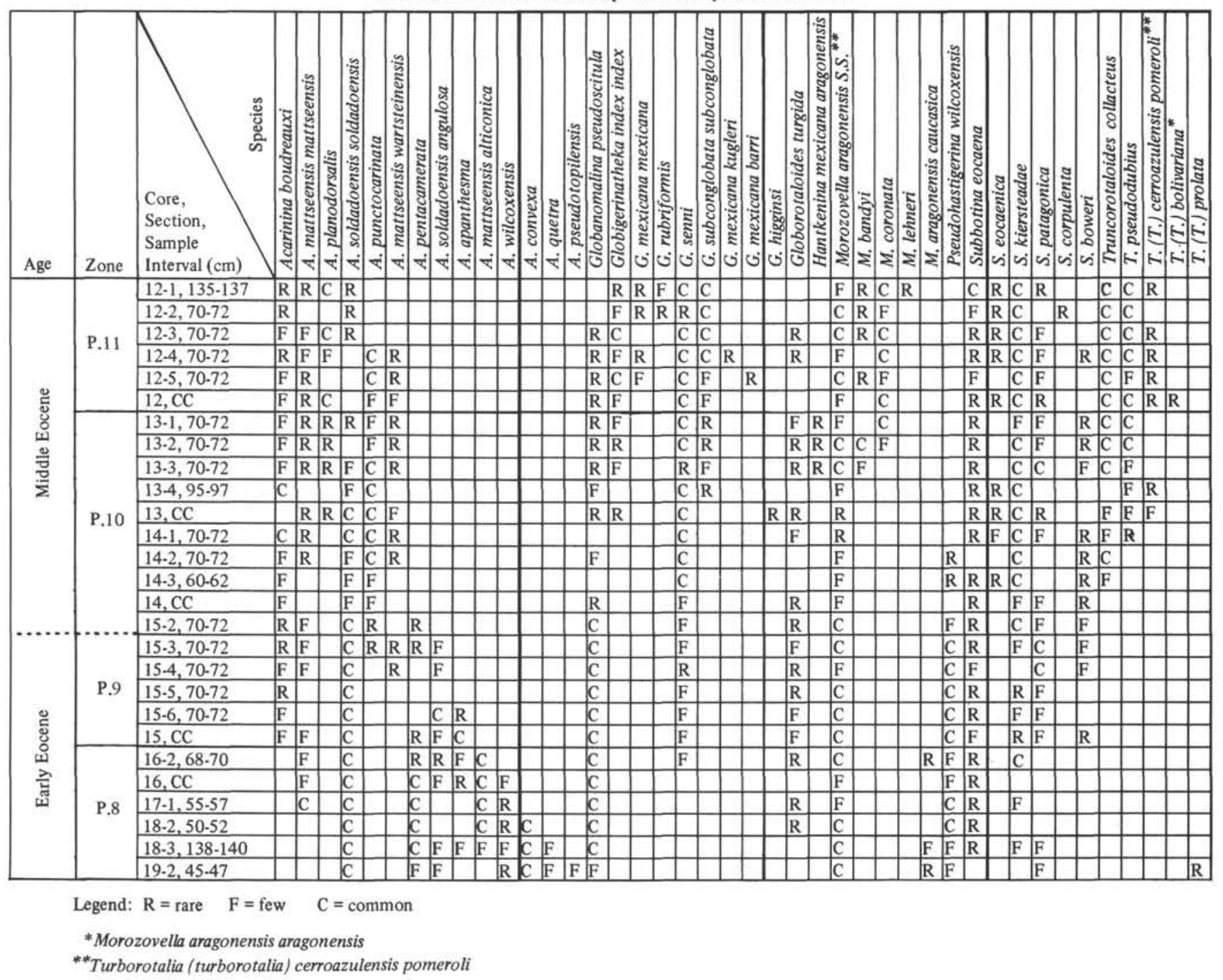

